\title{
Writing the Eternal: Reason and Rhetoric in Plato's Phaedrus
}

\author{
by
}

\author{
Tiago de Almeida Lier
}

A thesis submitted to the Faculty of Graduate and Postdoctoral Affairs in partial fulfillment of the requirements for the degree of

Doctor of Philosophy

in

Political Science

Carleton University

Ottawa, Ontario

(C) 2012, Tiago de Almeida Lier 
Library and Archives

Canada

Published Heritage

Branch

395 Wellington Street

Ottawa ON K1A ON4

Canada
Bibliothèque et

Archives Canada

Direction du

Patrimoine de l'édition

395 , rue Wellington

Ottawa ON K1A ON4

Canada
Your file Votre référence

ISBN: 978-0-494-94223-9

Our file Notre référence

ISBN: $978-0-494-94223-9$
NOTICE:

The author has granted a nonexclusive license allowing Library and Archives Canada to reproduce, publish, archive, preserve, conserve, communicate to the public by telecommunication or on the Internet, loan, distrbute and sell theses worldwide, for commercial or noncommercial purposes, in microform, paper, electronic and/or any other formats.

The author retains copyright ownership and moral rights in this thesis. Neither the thesis nor substantial extracts from it may be printed or otherwise reproduced without the author's permission.
AVIS:

L'auteur a accordé une licence non exclusive permettant à la Bibliothèque et Archives Canada de reproduire, publier, archiver, sauvegarder, conserver, transmettre au public par télécommunication ou par l'Internet, prêter, distribuer et vendre des thèses partout dans le monde, à des fins commerciales ou autres, sur support microforme, papier, électronique et/ou autres formats.

L'auteur conserve la propriété du droit d'auteur et des droits moraux qui protege cette thèse. $\mathrm{Ni}$ la thèse ni des extraits substantiels de celle-ci ne doivent être imprimés ou autrement reproduits sans son autorisation.
In compliance with the Canadian Privacy Act some supporting forms may have been removed from this thesis.

While these forms may be included in the document page count, their removal does not represent any loss of content from the thesis.
Conformément à la loi canadienne sur la protection de la vie privée, quelques formulaires secondaires ont été enlevés de cette thèse.

Bien que ces formulaires aient inclus dans la pagination, il n'y aura aucun contenu manquant. 


\begin{abstract}
This dissertation argues that Plato's Phaedrus shows that the way things are "shown forth" or manifested has ethical and psychological consequences that necessitate finding a way of using speech that is capable of breaking through common opinion and opening a view to reality. For Plato, this problem originated in the practice of rhetoric. In the character of Phaedrus, rhetoric has eroded his belief in any substance behind the words, and consequently his trust in what cannot be immediately discerned by the senses: ancient myths, gods, the piety and even laws of Athens, and perhaps the soul. His friend Lysias' written speech on "non-love" illustrates how rhetoric may use the confusion and contradictory opinions of its audience to persuade it of what is false. Socrates ironically improves Lysias' speech to show that its attack on erōs entails a dichotomy between erōs and opinion, which subordinates logos, the rhetorician, and reality, to common opinion and desires. But the self-contradiction of "non-love" shows that erōs also underlies opinion, which implies the presence of a higher erōs that seeks to reconcile speech with reality for the sake of action. Socrates' second speech shows that erōs can lead speech to reality because erōs is the fundamental experience of the soul's longing for what is whole and unchanging. This longing is only truly satisfied by using speech as reasoning (logismos) to intellect what really is, which transcends what is manifested to our senses and merely gratifies us. Therefore the highest form of erōs is the life of philosophy, which searches behind such beautiful manifestations. So long as rhetoric cannot find the real causes of the soul's gratification, and how to manifest them in speech, it will never light upon the complete persuasiveness befitting an art, and if rhetoric refuses this task altogether, speech becomes a superficial instrument for disorderly passion. Yet the
\end{abstract}


feasibility of such an art is called into question by Socrates' searching erōs, which, for its own part, cannot supersede the popular efficacy of contemporary rhetoric. Plato's own rhetoric combines philosophical dialogue and superficial gratification in writing in order to address the whole range of erōs, and to inculcate in his readers an ethos of active intellection of what lies behind logos, which is the only way for the nature of things to truly show forth. 


\section{ACKNOWLEDGEMENTS}

This dissertation would not have been possible without the support of the members of the committee, particularly my dissertation supervisor, Professor Waller Newell, whose advice, courses, and writings have greatly affected my reading of Plato. Professors Peter Emberley and Tom Darby provided constant encouragement and always useful comments and suggestions. Professor Gregory Maclsaac's course on the

Theaetetus and advice on dialectic allowed me to cut through otherwise perplexing issues that were critical to my study of the Phaedrus. In his role as external reviewer, Professor Ryan Balot was immensely helpful in challenging me to synthesize my conclusions and situate the dissertation in broader issues of scholarship on Plato and the history of political philosophy. I am also indebted to Professor Josh Beer, whose Greek lessons always found the measure of being enjoyably exacting. Friendship with various colleagues at Carleton University allowed for pointed discussions that were both immensely enjoyable and helpful in clarifying my understanding of Plato's arguments, not least conversations with ostensible anti-Platonists Ryan McKinnell and Denis Madore, and the ostensibly Platonic Jonas Schwab-Pflug. Most of all, I would like to thank my wife, April McGrath, for her patient support, willingness to endure speculations at the dinner table, and encouragement during the most trying periods.

Over the course of my doctoral studies, generous financial support from Carleton University, the Social Sciences and Humanities Research Council, and the Ontario Graduate Scholarship Program afforded me the leisure to devote my attention to this dissertation and bring it to completion. 


\section{TABLE OF CONTENTS}

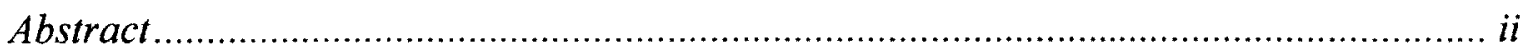

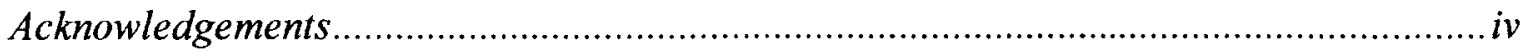

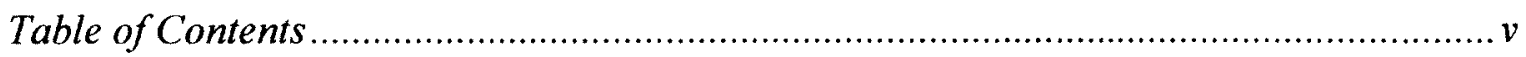

A Note on the Greek ............................................................................................ vii

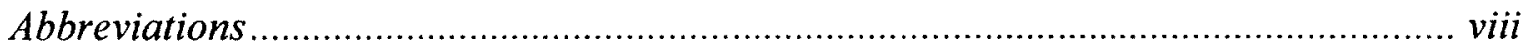

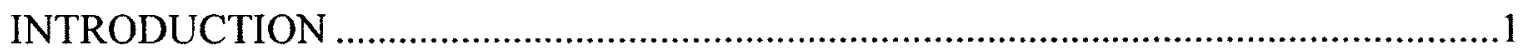

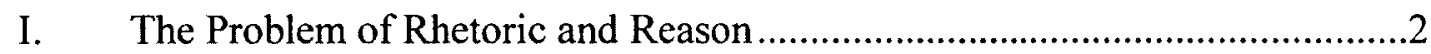

II. The Study of the Phaedrus......................................................................12

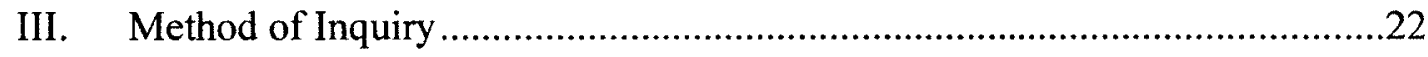

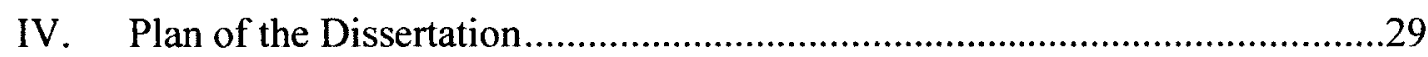

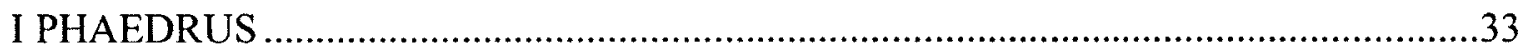

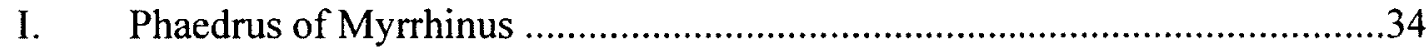

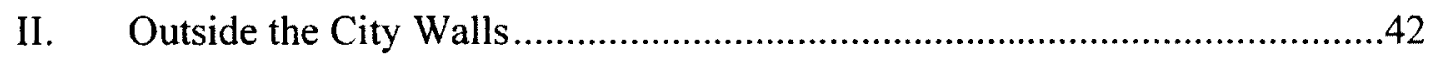

III. The Myth of Boreas and the Business of Socrates ........................................53

IV. Initiation into the Lesser Mysteries ............................................................62

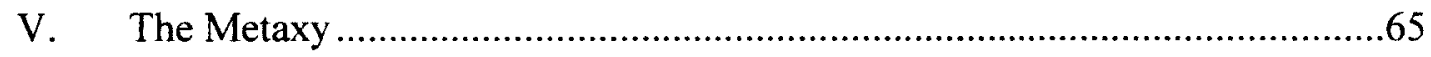

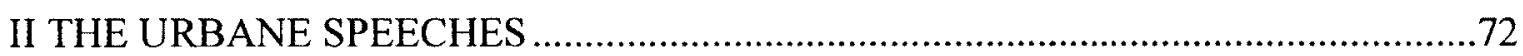

I. The Written Speech of the Non-Lover ........................................................73

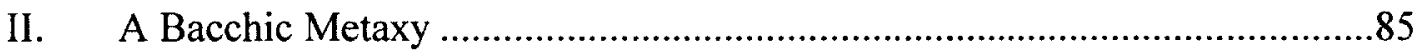

III. Socrates' Inspired Concealment of Love .........................................................93

IV. The Urbane Speeches .............................................................................113

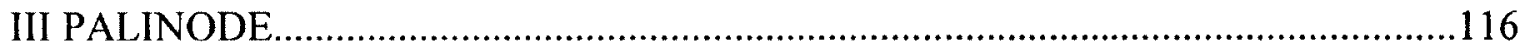

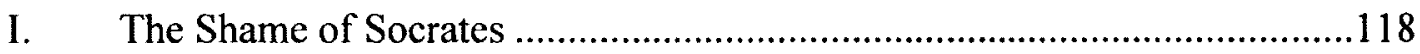

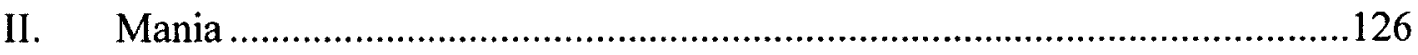

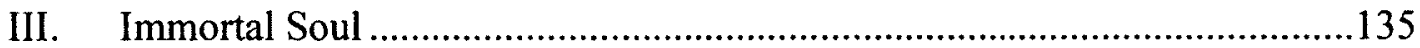

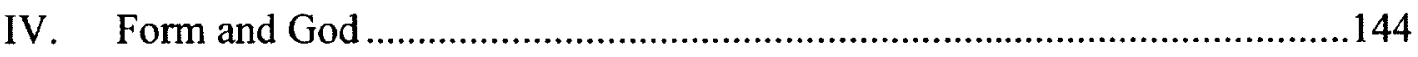

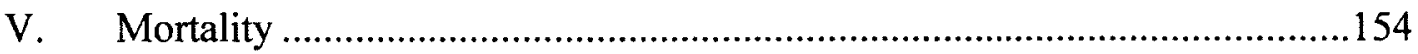

VI. Recollection and Eros ..............................................................................170

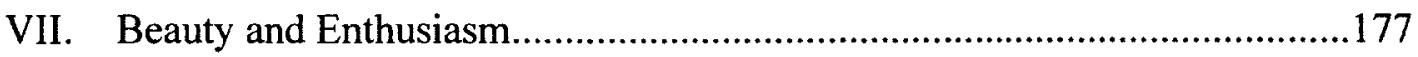




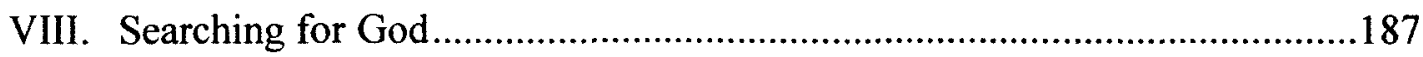

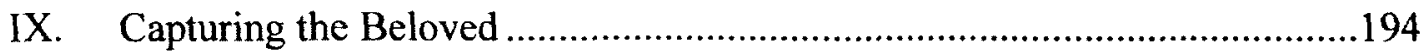

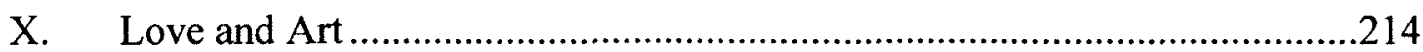

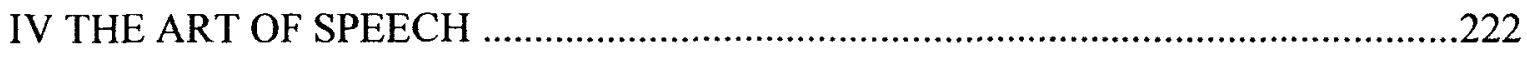

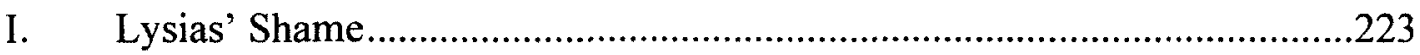

II. The Immortal Song of the Cicadas ............................................................228

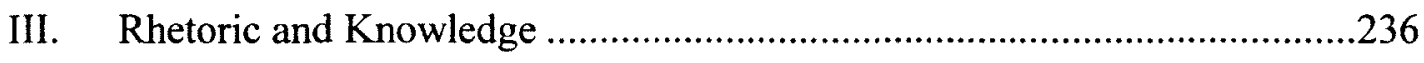

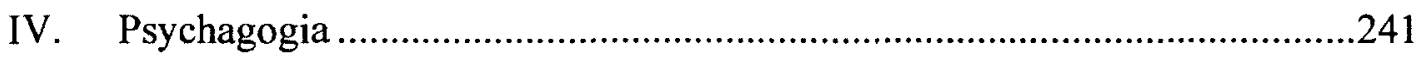

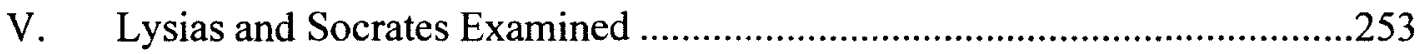

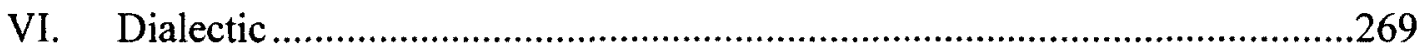

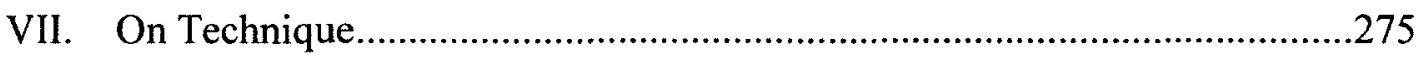

VIII. The Noble Rhetoric...............................................................................290

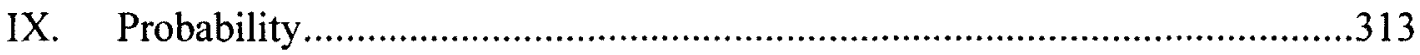

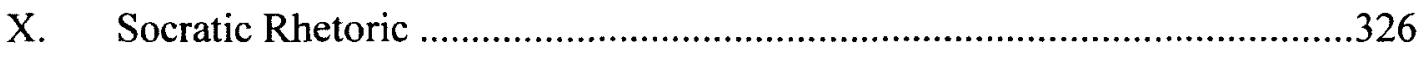

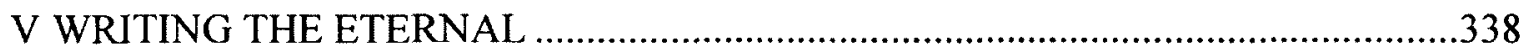

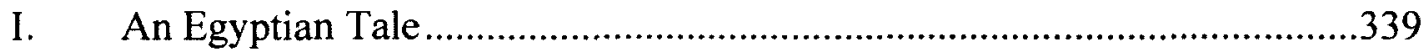

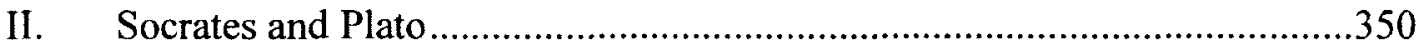

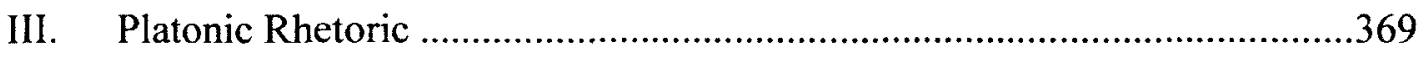

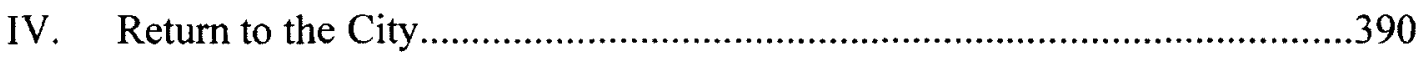

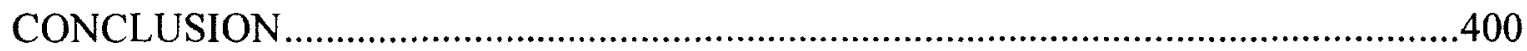

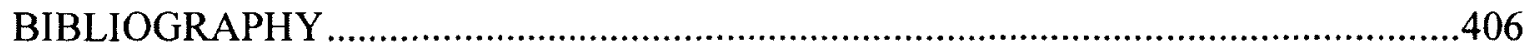

APPENDIX I: SYNOPSIS OF THE PHAEDRUS …………………..........................414

APPENDIX II: THE THREE DIVISIONS OF EROS ……............................................416 


\section{A NOTE ON THE GREEK}

Greek terms of special note, or that have supplementary meanings that shed light on their organic use, are transliterated. The assumption in this is that Plato, being a consummate writer of prose, was thoroughly aware of the numerous uses and meanings of the words he employed as they occurred in Greek literature. The playful exploitation of this multiplicity of meaning does not indicate that Plato lacked a technical or precise vocabulary, but that his vocabulary accounted for the plasticity inherent to the logos. Unless otherwise noted, substantives are written in the nominative and verbs in the present infinitive. For the sake of familiarity, proper names are in the Latin spelling.

All translation of the Greek is the author's, done in consultation with other translations on points of dispute that have interpretive implications. Translations of Plato's work are based on the Greek text edited by John Burnet, alongside the invaluable commentaries on the Phaedrus written by G. J. de Vries, C. J. Rowe, and Harvey Yunis. All other translations are based on the texts of the Loeb Classical Library published by Harvard University Press. 


\section{ABBREVIATIONS}

The first citation of a classical text indicates the author's name and title, with its abbreviation in parentheses. All subsequent citations are abbreviated. Abbreviations follow Liddell, Scott, and James's A Greek-English Lexicon, while fragments are numbered according to the edition cited in parentheses. For convenience, the most frequent citations are listed below.

$\begin{array}{cl}\text { Arist. } & \text { Aristotle } \\ \text { EN } & \text { Nicomachean } \\ & \text { Ethics } \\ \text { Pol. } & \text { Politics } \\ \text { Rh. } & \text { Rhetoric } \\ \text { Top. } & \text { Topics }\end{array}$

Apollod. Apollodorus, Library

D. H. Dionysius Halicarnassus

DK Diels and Kranz, [The Fragments of the Pre-Socratics]

Gorg. Gorgias

LSJ Liddell and Scott, supplem. Jones, $A$ Greek-English Lexicon

Lys. Lysias

Hdt. Herodotus, Histories

Hes. Hesiod

Op. Works and Days

Th. Theogony

Hom. Homer

Hymn. Homeric Hymns

Il. Iliad

Od. Odyssey

Isoc. Isocrates

$\begin{aligned} & \text { Pl. } \text { Plato } \\ & \text { Ap. } \text { Apology } \\ & \text { Clit. } \text { Cleitophon } \\ & \text { Cra. } \text { Cratylus } \\ & \text { Crit. } \text { Crito } \\ & \text { Ep. } \text { Letters } \\ & \text { Euthd. } \text { Euthyphro } \\ & \text { Euthydemus } \\ & \text { Ma. } \text { Greater Hippias } \\ & \text { Mi. } \text { Lesser Hippias } \\ & \text { lon } \text { Ion } \\ & \text { Lg. } \text { Laws } \\ & \text { Men. } \text { Meno } \\ & \text { Phd. } \text { Phaedo } \\ & \text { Phdr. } \text { Phaedrus } \\ & \text { Pol. } \text { Statesman } \\ & \text { Prm. } \text { Parmenides } \\ & \text { Prt. } \text { Protagoras } \\ & \text { R. } \text { Republic } \\ & \text { Smp. } \text { Symposium } \\ & \text { Sph. } \text { Sophist } \\ & \text { Thg. } \text { Theages } \\ & \text { Tht. } \text { Theaetetus } \\ & \text { Ti. } \text { Timaeus } \\ & \text { Xen. } \text { Xenophon } \\ & \text { Ap. } \text { Apology } \\ & \text { Mem. } \text { Memorabilia } \\ & \text { Smp. } \text { Symposium } \\ &\end{aligned}$

Euthd. Euthydemus

Hp. Ma. Greater Hippias

Hp. Mi. Lesser Hippias

Ion Ion

Lg. Laws

Men. Meno

Phd. Phaedo

Phdr. Phaedrus

Pol. Statesman

Prm. Parmenides

Prt. Protagoras

R. Republic

Smp. Symposium

Sph. Sophist

Thg. Theages

Tht. Theaetetus

Xen. Xenophon

Ap. Apology

Smp. Symposium 


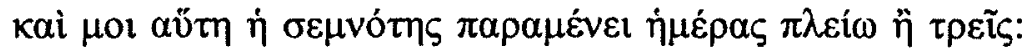

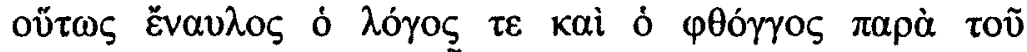

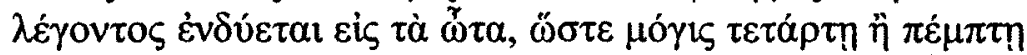

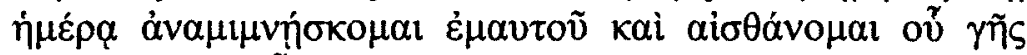

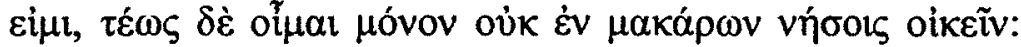

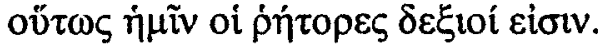

And this majestic feeling remains with me for more than three days: so persistently does the speech and voice of the one speaking ring in my ears that it is scarcely by the fourth or fifth day that I remember myself and perceive that I am on earth, but up until then I all but believe myself to be living in the Isles of the Blessed - so skilful are our rhetoricians.

- Menexenus 235b-c

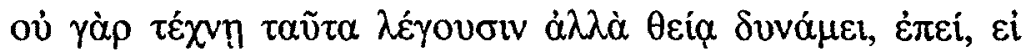

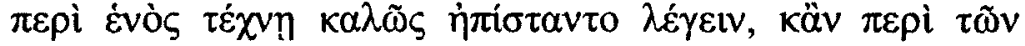

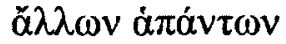

For the poets do not say these things by art but by divine power, since, if they knew how to speak beautifully by art with respect to one thing, they would also know how to do so with respect to all other things.

- Ion $534 \mathrm{c}$ 


\title{
INTRODUCTION
}

\author{
What struck me most in reading this dialogue \\ was that Plato, while satirizing the orators, seemed \\ himself to be the greatest orator of them all \\ - Cicero $^{1}$
}

The Platonic corpus as a whole can be regarded as a eulogy to Socrates and a defence of the philosophic life, but it is only Plato's dialogue the Phaedrus that makes the form of this eulogy - the written word - an object of inquiry. This dissertation will argue that Plato's Phaedrus shows that the way things are "shown forth" or manifested has ethical and psychological consequences that necessitate finding a way of using speech $(\log o s)^{2}$ that is capable of breaking through common opinion and opening a view to reality. For Plato, this problem originated in the practice of rhetoric. The power of rhetoric to manipulate what is shown forth has eroded Phaedrus's belief in any substance behind words, as well as his trust in what cannot be immediately discerned by the senses, such as ancient myths and perhaps even the soul. His friend Lysias' written speech on "non-love" shows how rhetoric uses the contradictory opinions of its audience to persuade it of what is false. The ethos of the common rhetorician is embodied in this attack on erōs, which Socrates shows to entail a dichotomy between erōs and opinion. This effectively subordinates speech, the rhetorician, and reality, to common opinion and desires. Moreover, the self-contradiction of "non-love" shows that erōs underlies opinion and implies a higher erōs for the reconciliation of speech with reality for the sake of action. Socrates' second speech endeavors to show the possibility of this reconciliation,

\footnotetext{
'Cicero, De Oratore (Cic. De or.) 1.11.47.

${ }^{2}$ The original meaning of logos is simply "speech," related to the verb legein, "to speak." Only over the course of its use by philosophers to indicate the apprehension of the nature of things did it also acquire the meaning of "reason," although it never lost its basic connotation of speech or discourse. In order to preserve this continuity, the transliterated logos will be used frequently, especially where it is necessary to recognize that both senses are relevant to the passage.
} 
on the grounds that $e r \bar{s} s$ is the fundamental experience of the soul's longing for what is whole and unchanging. Only speech, as reasoning (logismos), can satisfy this longing, for it allows the intellection of what really is, beyond what is manifested to our senses and merely gratifies. The highest form of erōs is therefore the life of philosophy, which searches behind such beautiful manifestations. If rhetoric cannot find the real causes of the soul's gratification, it will never light upon the complete persuasiveness befitting an art; and if rhetoric refuses this task altogether, speech becomes a superficial instrument for whatever passions might seize the speaker. Although Socrates outlines an art of rhetoric that promises to be true, complete, and popularly efficacious, his own searching erōs calls into question its feasibility. In light of this, Plato's rhetoric combines philosophical dialogue and superficial gratification in writing in order to address the whole range of erōs, and to inculcate in his readers an ethos of active intellection of what lies behind the words, which is the only way for the nature of things to truly show forth.

\section{The Problem of Rhetoric and Reason}

In a time when rhetoric as a credible practice let alone academic discipline is at perhaps its lowest ebb in over two thousand years, a close study of Plato's Phaedrus, one of the inaugurating texts of the rhetorical tradition, ${ }^{3}$ demands some justification if it is to be of more than antiquarian interest. In the introduction to his edition and translation of the Phaedrus, C. J. Rowe does not exaggerate greatly when he claims that "[i]n our own society, rhetoric no longer exists as a subject for formal inquiry - except perhaps in relation to the criticism of literature - or for teaching."4 Rhetoric is now popularly

\footnotetext{
3 Jaeger 3.191; Kennedy 59-60; Schleiermacher 73.

${ }^{4}$ Rowe 198613.
} 
believed to be synonymous with the deceptive and unprincipled, if not immoral, manipulation of opinions. In this sense, Plato's condemnation of rhetoric in his Gorgias, that it is a form of gross and harmful flattery, seems to have found a modern restatement, if not direct descendent. There are of course significant differences between the modern and Platonic attack on rhetoric. The Gorgias set Plato and Socrates against the currents of contemporary popular opinion in Athens, for rhetoric or the art of speaking had become one of the paramount arts, if not the paramount art. Athens's democratic regime gave such extensive authority to the assent of large assemblies and councils that political and legal success, and sometimes even one's life, depended on the ability to persuade crowds of the merits of one's case or the flaws of an opponent's (or the flaws in their character). The ubiquity and political importance of rhetoric accordingly afforded it and its adept practitioners great status, and its teachers significant wealth.

In the modern democracy, this ubiquity is grudgingly acknowledged, for public persuasion is an indelible part of democracy as such, even if it is now largely restricted to partisan activity surrounding the election of representatives to government. Meanwhile, administrative and policy decisions are largely entrusted to a professional civil service that is trained in a variety of technical areas and consults with scientific experts. Insofar as it is scientific expertise that commands authority in matters of knowledge, the use, or at least apparent use, of scientific results is also a practical necessity for public persuasion. Science has become an institution of public life and governance to an extent unparalleled in history. Modern political life is consequently at the center of a duality characteristic of the modern mind, between scientific reasoning capable of disclosing the nature of things and popular opinion that, despite it being un-scientific and therefore 
incapable of real understanding, must nevertheless assert political authority. Perhaps the insufficiency of science for the actual guidance of practical affairs could allow a place for rhetoric, along the lines of the old Aristotelian distinction between the precise theoretical sciences, such as mathematics, and imprecise practical sciences, such as political science. Rhetoric would guide political deliberation, inventing arguments suitable for the indeterminacy of practice and limitations of human experience, towards suitable ends. ${ }^{5}$ It is with regard to the ends of action, however, that the case for rhetoric again falters.

Since practical deliberation entails judging between better or worse ends, that is, a hierarchy of valuations, science must recuse itself because value as such cannot be an object of scientific knowledge, and perhaps not even an object of knowledge simply. This refusal of the value-judgment is not a mere preference or politic decision by the particular scientist, but constitutive of science itself, for the absolutely certain demonstration of facts cannot begin from premises that are themselves not universally acknowledged, and the ends of action and deliberation, being matters of deliberation, are not universally acknowledged. ${ }^{6}$ From this necessary rejection of value, as well as the principle of adapting one's speech to the particular audience, follows the rejection of rhetoric. The rejection of rhetoric therefore originates from the very heart of modern science, and has indeed been necessary for the great success of that science. ${ }^{7}$ Moreover, the highest objects of ancient political science, namely goodness, justice, and virtue, can only be objects for modern political science so far as their most widely acceptable elements may be discerned. The axioms of modern political science are consequently the

\footnotetext{
${ }^{5}$ Aristotle, Nicomachean Ethics (Arist. EN) 1094b11-28, 1139a-1140b; Rhetoric (Rh.) 1.2.1356a22-33, $1357 \mathrm{a} 23-\mathrm{b} 26,1.3,1.4 \mathrm{ff}$.

${ }^{6}$ Weaver notes that facts can never be "dialectically determined," but are fundamentally non-discursive (27-8).

${ }^{7}$ Simons 1990 8-14.
} 
basic conditions of human living, to which all positive statements of value must refer if they are to be founded upon reason. In effect, political science is instrumental, and rhetoric is judged accordingly. Since neither science nor rhetoric is capable of demonstrating any truth with respect to value itself, and only science may attain knowledge concerning fact, rhetoric is lost as if in a wasteland. So far as rhetoric does not aim towards generally accepted ends, but rather to what are seen as controversial and partisan ends, it is merely an instrument for values that are indemonstrably superior to any others - it is a servant of ideology and so mere or empty rhetoric. Even in the best case, where rhetoric is in the closest possible proximity to science and true understanding, rhetoric can only serve science in a popularizing capacity, informing the public of its results and what action may be taken accordingly.

To be sure, a broader conception of the function of language or speech in reasoning may find resemblances between scientific reasoning or demonstration and rhetorical argument. There has been an increased study of the institution and methods of science as socio-political phenomena in their own right, which has shown a pervasive use of rhetoric in scientific practice, such as in the choice of questions, differentiation from non-science, presentation of data, and the discursive practices and norms governing the securing of funding and publication. ${ }^{8}$ Few studies of the "rhetoric of science" are willing, however, to consider the most radical application of rhetoric to science, particularly in light of the understanding of modern rhetoric as non-science, which may be tacitly accepted. On the other hand, radical inquiries into the relationship between speech and knowledge have not shied away from these implications, and have consequently become

\footnotetext{
${ }^{8}$ Gaonkar 39-40; Gross 7-18; Simons 4.
} 
the centerpieces of the postmodernist intellectual movement that defines itself in contradistinction to modern rationalism.

From the broadest view, postmodernism concerns the study and critique of the discursive practices by which power is established and maintains itself. Two important sources for this movement are the scientific study of cultural practices and historicist philosophy, which concludes that the very possibility of understanding and knowledge is limited by time and place. Language is at the center of this limiting of the horizons of thought, for it is from within the context of meaning produced by a shared history and language that the thought of the individual originates and develops. Michel Foucault writes that "we are subjected to the production of truth through power and we cannot exercise power except through the production of truth." " So long as thought is unaware of its historicity, it is doomed to remain parochial and fettered by an understanding that is both common and dependent on nodes of power. Indeed, any act or speech has meaning, whether for the actor or observer, so far as it is in relation to these nodes of power, and as such is another expression of power. ${ }^{10}$ A strictly objective view of reality, outside its conception in language, is impossible - even the very belief in such a reality must, after all, be conceived and expressed in speech. The task for the individual is consequently to emancipate himself through the careful study of the discursive practices that determine or structure thought, although the final impossibility of such a task is well understood. For Foucault, the thinker asserts himself against the prevailing power, not to free himself from power as such or to grasp an objective truth, but to assert power. ${ }^{11}$ Alternatively, Jacques Derrida pursues the "deconstruction" of texts and the assertion of "différance" as

\footnotetext{
${ }^{9}$ Foucault 1980 93; see also 99.

${ }^{10}$ Ibid., 86, 98; Foucault 1983 90-1.

${ }^{11}$ Foucault $198082-3$.
} 
the subject's perception and subversion of the structures of reasoning that determine thought. ${ }^{12}$ Speech for Derrida is entirely performative and a matter of play, since any interpretation of speech, oral or written, is itself a writing unto itself. ${ }^{13}$ Given the omnipotence that these men attribute to speech, it is not surprising that postmodernism and post-structuralism have been a source of renewed interest in rhetoric and its history. A number of writers have found kindred spirits in the sophists, especially Gorgias, who in a number of fragments both rules out the existence of reality ("being") or possibility of expressing it, and accordingly speaks of the magical power of his art of rhetoric. ${ }^{14}$ Derrida himself returned to Plato's Phaedrus in a famous essay, "La Pharmacie de Platon," in order to argue that even this founder of "the history of metaphysics" was unable to escape his own criticism of writing and obtain a glimpse of reality outside logos. ${ }^{15}$ The reassertion of the power of speech and rhetoric through postmodernism has been won at the price of the relation between speech and reality that imbued logos with its original meaning, which has come down to us through the philosophical and scientific tradition as "reason." 16 When the rhetoric that has been emptied by modern science is turned upon science itself, one may "capture the historically contingent and radically uncertain character of all scientific claims, even the most successful." ${ }^{17}$

These extravagant claims have met resistance from some students of rhetoric. Dilip Gaonkar, for example, argues that such an expansive understanding of rhetoric, a

\footnotetext{
${ }^{12}$ Derrida 83, 89-93, 168.

${ }^{13}$ Ibid., 63-4, 168.

${ }^{14}$ Simons 5-7. See esp. Gorgias (Gorg.) On Nature or Non-being (fr. B3 [DK]), Defense of Palamedes (fr. B11.10 [DK]). Gross goes so far as to say that Aristotle's Rhetoric "is also Sophistic," and can only keep in check the radical scope of rhetoric by limiting it to political and judicial realms (Gross 1990 3-4).

${ }^{15}$ Derrida 103, 149, $159 \mathrm{ff}$.

${ }^{16}$ Heraclitus was the first to articulate this relation: "Listening not to me but the logos, it is wise to agree that all things are one" (fr. B50; see also B1 [DK]).

${ }^{17}$ Gross 7.
} 
"general hermeneutic" applicable to all forms of symbolic use, not only trivializes rhetoric but risks losing sight of what "motivates and steers rhetoric." ${ }^{\prime 8}$ But any rehabilitation is unpersuasive insofar as it does not redress modern science's rejection of value as a matter of knowledge. If rhetoric appeals to and is based on opinions and practice, then it is only an expression of value and subjectivity, and as such will never be a knowledgeable guide for, or interpretation of, action.

The modern state of rhetoric is not, however, a matter of course or simply natural. It is the product of the deliberate depreciation of an older and more august tradition of rhetoric by sixteenth and seventeenth century philosophers who styled themselves moderns in opposition to classical philosophy and science. The work of Thomas Hobbes is a particularly clear attack on rhetoric or "eloquence" in favor of "true moral philosophy" and political science that may found a lasting peace upon the certainties of geometric reasoning. ${ }^{19}$ At the heart of the political problem identified by Hobbes is the ignorance and doubt of the individual with respect to the true causes of all things and consequently their fear that they may not attain what they desire. ${ }^{20}$ When this is compounded by the naturally unlimited "progress of the desire, from one object to another," the vanity of "seeming prudence" instilled by eloquence and specious reasoning, and the lack of "settled names," there arises competition and quarrel. ${ }^{21}$ So long as each vainly believes his cause just, there will be neither peace nor true justice. Rhetoric and the use of exhortation, through "similitudes, metaphors, examples," fosters sedition by inflaming the ambition of the eloquent and, particularly when joined with

\footnotetext{
${ }^{18}$ Gaonkar 25, 69, 77.

${ }^{19}$ Hobbes, Leviathan $x v .40$.

${ }^{20}$ Ibid., xi.1-5, 17-27.

${ }^{21}$ Ibid., vi.7, xi.3, 17-21, xiii.1-6.
} 
flattery, preying on the ignorance of the many who must rely on the authority of others. ${ }^{22}$ Only when each citizen is instructed in the use of their reasoning will they see that the attainment of their desires depends upon the continued peace of the commonwealth; the security of the sovereign's power depends not on the force of law or fear of punishment but public education. ${ }^{23}$

A secure peace therefore depends on the certainty of reasoning or the "general and infallible rules called science." ${ }^{24}$ Hobbes's science is modeled on geometry, proceeding from "definitions and settled significations of names" to their consequences, like the arithmetic addition or subtraction of basic elements, "for there can be no certainty of the last conclusion without a certainty of all those affirmations and negations on which it was grounded and inferred. ${ }^{25}$ In a crucial departure from the ancients, Hobbes follows Descartes by not beginning from opinion, which is fraught with the improper use of names, fallible reckoning of causes, great popular disagreement, and reliance on the authority of men and writings. Rather, "infallible" science begins from a radical doubt concerning the spoken intentions of men and indeed all discourse: "No discourse whatsoever can end in absolute knowledge of fact." ${ }^{26}$ Certainty only arises from the recognition of this fundamental uncertainty and the unknowable link between the fact of sensory experience and the significations used in reasoning; there is no understanding of the things themselves but only of signs, i.e., the names imposed on the consequences of sensory experience. Science is the preeminent instance of man making himself. ${ }^{27}$ The

\footnotetext{
${ }^{22}$ Ibid., x. 12, xi.13-22, xxv.6-9.

${ }^{23}$ Ibid., $x x x .2-5$.

${ }^{24}$ Ibid., v.21, xiii.2.

${ }^{25}$ Ibid., iv. 12-13, v.1-4.

${ }^{26}$ Ibid., "Introduction" 3, vii.1-3.

27 Ibid., "Introduction" 1-2.
} 
end of political science is consequently the demonstration that the passions of the individual cannot be fulfilled without the free creation of a civil authority sufficiently powerful to secure contracts and to give the proper signification of words, which are otherwise used according to the passion of each. Insofar as eloquence plays on the passions and enjoins the improper signification of words, or re-interprets the law, it will endanger both reasoning and civil peace.

Hobbes was a keen student of Aristotle's Rhetoric and aware that his distinction between the true reasoning of science and rhetoric was indistinct because they both originated from common opinion. ${ }^{28}$ Petrus Ramus had, a century earlier, accused Aristotle of confusing dialectic and rhetoric by granting the latter the power of the invention of argument, and Hobbes went even further by claiming that the ancients were bereft of all science. ${ }^{29}$ Although Hobbes regarded Plato "the best philosopher of the Greeks," in no small part due to his favoring of the precision of geometric reasoning, none of the ancients were spared for introducing into reasoning endless disputation and disagreement, such that "their logic, which should be the method of reasoning, is nothing else but captions of words." ${ }^{30}$ The ancients' belief that knowledge concerning natural causes, let alone the existence of a natural end for human life, could be obtained from opinions was absurd, for opinion is no more than discourse without definition, and if such discourse begins not from oneself but another it is but belief or faith. ${ }^{31}$ In particular, the belief in "separated essences," i.e., essences that are beyond mere corporeality and cannot

\footnotetext{
${ }^{28}$ Hobbes's early The Whole Art of Rhetoric was largely Aristotelian (English Works VI). On the relation of dialectic and rhetoric to opinion in Aristotle, cf. EN 1.4.1095a31-b13, Rh. 1.1.1351al-11, 1355a6-29, Topics (Top.) 1.1-2, 11, 14.

${ }^{29}$ Ramus 1992 8; Hobbes, Leviathan xlvi.

${ }^{30}$ Hobbes, Leviathan xxi.9, xlvi.11.

${ }^{31}$ Ibid., vii.4-5.
} 
be completely understood, particularly the summum bonum ("greatest good"), is ruinous of civil peace, since it posits a natural good or authority outside of law. ${ }^{32}$ For calling such senseless words objects of science, Hobbes bestowed upon Aristotle's eloquence the epithet "vain philosophy."

While Hobbes's criticism of eloquence echoes a number of Plato's arguments in the Gorgias, e.g., the flattery of the passions, the susceptibility of crowds and assemblies, the use of long speeches as opposed to the use of questions in private, etc., ${ }^{33}$ Hobbes does not leave a place for rhetoric in his political science or moral philosophy as Plato did, most conspicuously in the Phaedrus. ${ }^{34}$ But Hobbes of course knew of what Plato called "the true art of rhetoric" or the noble use of speech, both as a political instrument of philosophy and in its relation to dialectic, in the form of the "private" rhetoric. In the "Review and Conclusion" of the Leviathan, Hobbes admits that "reason and eloquence ... may stand very well together." ${ }^{35}$ Indeed, the science he promulgates seems to depend on rhetoric. Science is "conditional" upon the application of right reasoning to matters of fact, and remains "uncertain" so long as "only some particular events answer to [one's] pretence [of knowledge]." ${ }^{36}$ Where science cannot demonstrate with certainty, the civil authority must rely on the ability to move opinions that are themselves founded on the passions - not least of all in promulgating the science upon which peace depends, through the basic passion of self-preservation. ${ }^{37}$ It is therefore for deliberate political reasons that Hobbes in his writings bifurcated the right reasoning of science and rhetoric,

\footnotetext{
${ }^{32}$ Ibid., iii.12, xi.1, xlvi.18, 32.

${ }^{33}$ Cf. Hobbes, Leviathan x.12, xi.13, xxv.6-8,15, and Plato, Gorgias (Pl. Grg.) 461d-462a, 462c ff., 471e$472 \mathrm{~d}, 503 \mathrm{c}-\mathrm{d}$.

${ }^{34}$ There are a number of brief indications of a noble use of rhetoric in Plato's other works, e.g., Grg. 504de, 508c, 517a, Laws (Lg.) 722d-723d, Statesman (Pol.) 303e-304e, Republic (R.) 498d.

${ }^{35}$ Hobbes, Levaithan "A Review and Conclusion" 1-4.

${ }^{36}$ Ibid., v.22, ix.1.

${ }^{37}$ Ibid., xiii.14.
} 
and indeed he did so rhetorically by demonstrating the deleterious consequences of the "vain-glory" that attempts to unify them. ${ }^{38}$ Whatever Hobbes's complete understanding of rhetoric was, his acknowledgment of a good or noble rhetoric and the implication that he himself had made use of it gives reason to suppose there is merit in considering Plato's own articulation of this sort of rhetoric. A return to the original confrontation of rhetoric and philosophy in the work of Plato will help remove the veil cast over rhetoric, and recover the full extent of the claims made by the art of speaking.

The study of the Phaedrus in particular will show why Plato never sought to eliminate rhetoric from political life or the auspices of philosophy. He was willing to consider the possibility that philosophy and what would later be called science was also a kind of rhetoric, perhaps its perfection. For Plato, only the philosophical study of the manner by which speech shows forth the nature of things can reinvest rhetoric with the ability to show what is valuable and fitting for human life. Perhaps in Plato's treatment of the problem of rhetoric and reason there may be found a way through the impasse of a modern science that cannot claim for itself any true value.

\section{The Study of the Phaedrus}

Since antiquity, Plato's Phaedrus has been an object of great interest. Most memorable have been its splendid images, whether its idyllic setting in a lush grove under a plane-tree, the likening of the soul to a winged chariot, or the train of souls traversing the arch of heaven. Allusions to these are easily identified throughout the history of literature. The prosaic discussion of rhetoric in the latter half of the dialogue is

\footnotetext{
${ }^{38}$ Ramus similarly rejected the classical conjunction of wisdom and eloquence as "useless and stupid" because it gave moral authority to eloquence, which even an evil man could possess (Ramus 2010 84-92).
} 
comparatively ugly, although immensely influential in its own right, with echoes of its arguments found in Aristotle's Rhetoric, Cicero's De Oratore, and indeed the whole subsequent rhetorical tradition. ${ }^{39}$ The enduring success of the dialogue is owed to its ability to appeal to this broad and various audience, simultaneously filling the popular imagination while providing such a substantive treatment of its subject matter to engross students of philosophy and rhetoric. Plato mastered his own principle of offering a multiform audience "multiform and panharmonic speeches," even in a medium he criticized for "not knowing to whom it must speak and to whom it must not" (275e, 277 c). ${ }^{40}$ While a number of Plato's other dialogues similarly weave together a complex array of arguments and themes through lively conversation, splendid imagery, and myths, the Phaedrus is outstanding in this regard because it does not readily admit to a single overarching thesis or even topic, as it addresses myth, erōs, madness, moderation, beauty, recollection, philosophy, logos, rhetoric, dialectic, and writing.

For Friedrich Schleiermacher, this thematic variety so verged on excess and superficiality that he declared the Phaedrus the product of Plato's youth and first of the dialogues. ${ }^{41}$ Others have gone even further and argued that the dialogue has no single theme or purpose at all, ${ }^{42}$ some to the extent of wondering whether the dialogue is genuinely Plato's or perhaps a pastiche of fragments and imitation. The latter opinion is not credible, though, since the authenticity of the Phaedrus has been attested to since antiquity, either by direct reference, quotation, or allusion. ${ }^{43}$ As to whether the dialogue

\footnotetext{
${ }^{39}$ A brief survey of the reception of the Phaedrus can be found in Yunis 2011 25-30.

${ }^{40}$ All parenthetical citations refer to the Phaedrus. Other sources are cited in footnotes.

${ }^{41}$ Schleiermacher 59,68 . Others see it as the product of weakened old age, with the same result (see de Vries 22).

${ }^{42}$ Jowett 9-10; Thompson xxi-xxii.

${ }^{43}$ De Vries 3.
} 
has any singular purpose at all, it is conspicuous that, in a work boasting such a broad array of themes, Plato's Socrates insists that a written work must be formed according to the principle of "logographic necessity," whereby the arrangement of the text is such that "every part fits to other parts and the whole" as if it were a living animal (264c). No shortage of commentators have noted the irony of this statement in relation to the form of the dialogue, and Plato's implicit challenge to his readers; ${ }^{44}$ as Schleiermacher memorably put it, to read the Phaedrus without attempting to discover its unity is to render it "deformed in a wholly revolting manner." 45 This endeavor is nothing less than an exercise in the art of dialectic that Socrates describes as the ability to collect from manifold parts or appearances a single view and then divide it seamlessly. The hermeneutic puzzle that Plato left, the so-called problem of unity, has ever since been the primary concern of scholarship on the Phaedrus. Indeed, the other principal scholarly questions concerning the Phaedrus all become elements of this overarching concern.

In the earliest extant commentary on the Phaedrus, Hermeias of Alexandria, a fifth-century Neoplatonist, surveys the variety of opinions already ventured concerning the dialogue's principal purpose. These include: erōs; rhetoric; erōs in the first half of the dialogue and rhetoric in the second; the ruling soul; and that it has no single overarching theme but several, including the soul, the good, and the highest beauty. None of these opinions are correct, Hermeias argues, for each expresses what is only a part as if it were the whole. Instead, following Iamblichus, each of these is encompassed

\footnotetext{
${ }^{44}$ E.g., Benardete 103; Burger 3-4; de Vries 22-3; Griswold 1986 10-12; Rowe 1986 7; Rutherford 260-7; Yunis $20111-2$.

${ }^{45}$ Schleiermacher 48-9, cf. 14-7. Seth Benardete calls the dialogue "a monster," in reference to Socrates' perplexity whether he is "some beast more complex and Typhonic than Typhon, or some living thing both quieter and simpler" (230a) (Benardete 105).
} 
by "the manifold beauty." "46 The Renaissance neoplatonist Marsilio Ficino similarly believed the "principal mysteries" of the dialogue to lie in its discussions of the desire for beauty, erōs. ${ }^{47}$ On the face of it, both arguments meet the immediate difficulty that beauty and erōs are for the most part obscured in the discussion of rhetoric in the second half of the dialogue and reduced to objects and examples. As Rowe points out, this effectively divides the dialogue into two rather than unifying it, ${ }^{48}$ even though this division is a natural one, in-between the three monologues on erōs and the dialogue concerning the nature of rhetoric, oral and written. The resolution of this basic dramatic division is therefore paramount to resolving the variety of themes. Why does Plato make Socrates and Phaedrus discuss the nature of rhetoric after delivering three monologues on erōs? What bearing does the discussion of rhetoric have on the content of those monologues, and, vice-versa, what bearing does the content of those monologues have on the discussion of rhetoric? To take each half alone as the purpose of the dialogue, the study of either erōs or rhetoric, would be unsatisfactory.

Several scholars argue that erōs is essentially linked to the persuasive use of speech, either in the ignoble rhetoric typified by Lysias or notable teachers of rhetoric such as Gorgias, Teisias, and Thrasymachus, or in the "divine" form of philosophy that seeks knowledge of the whole of nature. ${ }^{49}$ The greatest objects of longing portrayed in the Phaedrus can, after all, only be achieved through the essentially human power of speech. Be that as it may, Plato's use of erōs derives its force from the broader nature of erös, which is addressed in far greater detail in the Symposium. Given that the Phaedrus

\footnotetext{
${ }^{46}$ Hermeias 8.15-9.6.

${ }^{47}$ Ficino 198172.

${ }^{48}$ Rowe 19867.

${ }^{49}$ Nicholson 73-4, 124; Rhodes 418-9; Sallis 71; Schleiermacher 58-9; White 1993 223-7.
} 
focuses primarily on the relation of erōs to speech, one cannot take erōs simply as the theme of the dialogue. Rather, a phenomenon or principle broader than each of the two parts of the Phaedrus must be discerned.

More plausible is the view that rhetoric is the principal theme of the Phaedrus, and erōs the minor premise. ${ }^{50}$ This would be redundant on Plato's part, however, since the Gorgias is wholly devoted to the subject of rhetoric. It is natural to therefore regard the Phaedrus as Plato's later understanding of rhetoric. ${ }^{51}$ Like the Gorgias, the Phaedrus is concerned with rhetoric characterized as ignoble or shameful. But in the Gorgias, a nobler form of rhetoric is only alluded to as the "right" or "true" rhetoric, ${ }^{52}$ while the Phaedrus develops this noble rhetoric out of the "private" rhetoric, which is not mentioned in the Gorgias. The theme of the Phaedrus would therefore be the nature of private rhetoric, or even dialectic as the pinnacle or essence of that rhetoric. This is the view of Schleiermacher: "all else in this dialogue is but preparation, in order to bring about the discovery of [dialectic] in the Socratic method by the exhibition of its spirit in a well known particular [i.e., erōs]. ${ }^{, 53}$ It is true that the emergence of dialectic is a critical moment of the Phaedrus, but what is its relation to the other peaks of the dialogue, particularly the ascent of the erotic soul to the view of true reality? Why is that moment of mere "preparation" afforded such a prominent place and style of presentation?

Dialectic after all emerges as a subject in several other dialogues without mention of erōs. Some understand the speeches on erōs as simply examples of various forms of rhetoric, without considering a more essential relation between erōs and the art of

\footnotetext{
${ }^{50}$ E.g., de Vries 23; Hackforth 9-11; Jaeger 3.184; Rhodes 418-9; Weaver 3-4.

${ }^{51}$ E.g., Hackforth 11; Jaeger 3.184-6; Kennedy 52; Nicholson 51-2.

${ }^{52}$ Grg. 504d-e, 508c, 517 a.

${ }^{53}$ Schleiermacher 57-9.
} 
speaking. ${ }^{54}$ To conclude that the first half of the dialogue is accidental to its real subject matter is hardly a satisfying solution to the problem of unity. On the other hand, if erōs is essentially related to dialectic, so that dialectic cannot be understood without an understanding of $e r \bar{o} s,{ }^{55}$ dialectic can no longer be the principal subject of inquiry. Since dialectic is the way by which reality is apprehended, ${ }^{56}$ its own nature could only be revealed dialectically - a direct approach to dialectic is circular. Dialectic must be transcended if it is to be understood; a view must be attained that distinguishes dialectic from the conditions of its possibility, namely the preexisting relation to reality that impels and guides dialectic, which Socrates calls erös.

The Phaedrus is therefore concerned with how dialectic emerges out of the erotic relation to reality, while at the same time erōs can only be made apparent through dialectic. This problem can be restated as the tension between erōs and dialectic, or more generally the tension between $e r \bar{s}$ and $\operatorname{logos} .^{57}$ Even if the theme of the Phaedrus is rhetoric or "the persuasive use of words" in the most general sense, ${ }^{58}$ the problem remains. Martin Heidegger's suggestion that the theme of the dialogue is the nature of $\log o s$ is satisfying only if it is understood as the articulation of the problem rather than the solution: "the theme is speaking in the sense of self-expression and communication, speaking as the mode of existence in which one person expresses himself to an other and both together seek the matter at issue" (emphasis added). Heidegger sees that this theme can be developed only in a total view of the human being "in its basic comportment to

\footnotetext{
54 Jaeger 3.186-7, 190.

${ }^{55}$ Schleiermacher 58-9.

56 Ibid.

${ }^{57}$ See Lebeck.

${ }^{58}$ De Vries 23. See also Weaver 14.
} 
beings pure and simple." 59 In short, the nature of the logos is only resolved with the resolution of the ontological question. It is questionable then whether the Phaedrus can really be unified except in potentiality. In practical terms, Heidegger's interpretation is concerned with rhetoric and logos almost to the complete exclusion of erōs. John Sallis, drawing heavily on Heidegger, reintegrates erōs to the effect that the problem of unity in the Phaedrus is Plato's manifestation of the perennial problem of the relation between erōs and $\log o s .{ }^{60}$ In a similar vein, Giovanni Ferrari is particularly concerned with the function of the dramatic setting in the Phaedrus as a literary instrument and metaphor for the "background" of the logos, "the enabling conditions of [the interlocutors"] conversation and their behaviour."61 The distinction between myth and dialectic grows from the tension between this background and the foreground of discourse.

Understandably, a return to the surface problem of the Phaedrus is unsatisfying for interpreters who keep in mind Socrates' insistence on logographic necessity. This has compelled some to look beyond the poles of erōs and logos for the source of their resolution. For Ronna Burger, the problem of the unity of the Phaedrus is of great importance philosophically as well as interpretively, for its resolution promises to resolve the problem of the Platonic dialogue as such, i.e., to show why Plato wrote dialogues and so gain insight into the basic unity of the whole corpus. ${ }^{62}$ Certainly the Phaedrus is the single most important source in this regard, and has often attracted attention solely on this basis - Derrida's famous essay being but one example - and the issue of writing is an

\footnotetext{
${ }^{59}$ Heidegger $1997 \S 51,218-9$. Sallis (10-11) shares this view.

${ }^{60}$ Sallis 160-1, 173-5; see also Friedländer 3.241-2. Griswold similarly says that "a given text may turn out to be deeply aporetic in the sense that it defines a problem and shows that there are no available solutions to it" (1986 12).

${ }^{61}$ Ferrari $19871-4,21-36$, esp. 25-6, 30.

${ }^{62}$ Schleiermacher was the first to note that the Phaedrus seems to serve as a kind of hermeneutical key to the interpretation of the whole Platonic corpus, which in part led him to the controversial and now obsolete opinion that it was the first dialogue that Plato wrote $(48,58,67-9)$. See also Benardete 1-2; Sallis 12-3.
} 
important part of any holistic interpretation of the dialogue. Burger consequently proposes that the unifying theme of the Phaedrus is nothing less than Plato's defense of philosophical writing, where its value as a reminder of the nature of things arises from its self-criticism. ${ }^{63}$ This ironic defense depends, however, on first establishing the principles of good writing, e.g., that "every logos [should] be constructed like a living animal." As Ferrari points out, the problem of writing is philosophically subordinate to the problem of logos and the art of speaking. ${ }^{64}$

Charles Griswold recognizes, as did Heidegger and Burger before him, that the study of the nature of logos is closely related to self-knowledge.$^{65}$ He elevation of selfknowledge to the principal theme of the Phaedrus is, however, unique. As he shows, "eros and logos are connected to each other in the desire to give a discursive description of oneself, that is, to self-knowledge." ${ }^{.66}$ Such knowledge touches on every part and subordinate theme of the dialogue, for it is "the understanding of what the soul 'really' desires"; the soul is erotically moved to the use of logos in order to attain knowledge of what is best for it. ${ }^{67}$ The quest for self-knowledge will consequently touch on every aspect of nature in order to discern the most basic principles as they truly are, and even the discussion of writing can be seen as an instance of Plato coming to know himself. Griswold is surely right to see the broad view to which the quest for self-knowledge leads, and indeed Socrates will claim that the art of speaking depends upon knowledge "of the whole" (270c). But if that is true, why does self-knowledge in the Phaedrus

\footnotetext{
${ }^{63}$ Burger 2-4.

${ }_{64}^{64}$ Burger 2; Ferrari 1987 206, 213-4.

65 "[It is clear] how completely Socrates was concerned with $\lambda$ ójos [logos], correct self-expression, insofar as he understood self-expression to involve nothing other than self-disclosure, i.e., the disclosure of the self to itself. Therefore ... he speaks of his passion for self-knowledge" (Heidegger $1997 \S 51,219$ ). See also Burger 5.

${ }_{66}^{66}$ Griswold 19865.

${ }^{67}$ Ibid., 4.
} 
concern itself with the particular subjects mentioned, e.g., erōs, madness, soul, logos, rhetoric, dialectic, writing, etc.? Why does it not take up the subjects found in other dialogues which, being crucial parts of the whole and enlightening as to "what the soul 'really' desires," such as the various virtues of justice, moderation, and courage, or broader questions concerning the nature of knowledge, being itself, and so on? So far as the Phaedrus takes up the question of self-knowledge, it only takes up that aspect of it which touches on a limited array of possible objects. It might be better said that selfknowledge is the theme of the Platonic corpus as a whole rather than peculiarly that of the Phaedrus. ${ }^{68}$

The expansive view to which the Phaedrus opens up, particularly in Socrates' second speech, has encouraged some commentators to see the theme of the dialogue as the relation of the human being to the whole of nature. Josef Pieper writes that Lysias' speech and Socrates' second speech form the poles of the "everlasting problem" between divinely inspired "transformative upheavals" and the need for moderate rational organization ("the all-too-human"), a tension that arises from man's involvement "in the Whole of reality. ${ }^{\prime 69}$ Phaedrus is consequently seen as embarking on a moral ascent from his association with sophists and their form of discourse to an ecstatic view of the whole that discloses what is best for him; the Phaedrus embodies the struggle to maintain one's openness to the whole. ${ }^{70}$ Pieper follows the natural tendency to read the dialogue through Socrates' great speech, which for some produces the view that Plato finally turned his

\footnotetext{
${ }^{68}$ See Ferrari 1988 409-10.

${ }^{69}$ Pieper 23, 36, 51, 102.

${ }^{70}$ Ibid., 92-3, 101-2. On the Phaedrus's development of discourse in parallel with a moral ascent, see also Friedländer 3.219, Rhodes 418-9, and Weaver 6-11.
} 
back on political life for the sake of a completely transcendental philosophy. ${ }^{71}$ Although Pieper avoids this interpretation, because he shows the basic tension expressed by the Phaedrus, he nevertheless takes the great speech to be such an unadorned expression of Socrates' and Plato's opinions that the discussion of rhetoric becomes a mere appendix detailing in logical terms the philosophic ascent to the nature of reality. ${ }^{72}$ But if there is in fact an "everlasting problem" between technical rationality and ecstatic moments of transcendence, it could hardly be the case that the noble rhetoric outlined in the second half of the dialogue could itself escape this tension and claim the power of a pure exposition of the truth. ${ }^{73}$

If one instead forgoes this everlasting problem, rhetoric and dialectic seem to be the means for disclosing the truth of reality as a coherent and "more articulated metaphysical position." "74 The vast scope of Socrates' speech in particular seems to allow for the reader to find in it the sum of Plato's thought, a poetic vision of themes and concepts from throughout the Platonic corpus, e.g., the so-called doctrines of the immortality of the soul, the Ideas, knowledge as recollection, the judgment of the dead, the tri-partite soul, and so on. ${ }^{75}$ To see the purpose of the Phaedrus as a synoptic account of the whole, however, means that one loses sight of the surface of the dialogue in which

\footnotetext{
${ }^{71}$ E.g., Eric Voegelin sees the Phaedrus as "the manifesto which announces the emigration of the spirit from the polis [city]" (Voegelin 3.193).

72 Pieper 39, 42-3, 97, 99.

${ }^{73}$ Pieper seems to recognize this, saying that Plato makes Socrates ask whether truth is also in need of rhetoric, and that "Socrates ... aggressively and ironically repudiates anything which goes beyond speaking the bare truth" (99, emphasis added). But Pieper neither develops this line of thought nor considers its implication for Socrates' great speech.

${ }^{74}$ White 19933.

${ }^{75}$ White, e.g., connects the Phaedrus to the Apology, Cratylus, Gorgias, Ion, Lysis, Meno, Phaedo, Republic, Sophist, Statesman, Symposium, and Timaeus (White 1993 1-2).
} 
its most difficult and peculiar questions appear. ${ }^{76}$ Not least of these questions is the problem formed between erōs and logos, and its corollary problem of madness in relation to art or technē. The question whether the dialectical study of soul, which Socrates says is necessary for the art of rhetoric, could ever attain the view of the whole depicted in Socrates' great speech is the most troubling question in the discussion of rhetoric. ${ }^{77}$ If the true art of rhetoric is not practically attainable, what is the status of Socrates' exhortation to that art? What is the status of his criticism of the ignoble rhetoric that eschews the search for truth altogether? But if the "articulated metaphysical position" of the Phaedrus can indeed be established, there is no question of the possibility of a true art of rhetoric, and erōs can be reconciled with logos and dialectic. ${ }^{78}$ The problems suggested by the Phaedrus are therefore heuristic, a ladder to be cast aside once ascended, rather than constituting the inspiring spring of philosophy as the continuous search for wisdom.

\section{Method of Inquiry}

In studying a work like the Phaedrus, the choice of a particular method of inquiry, or whether a method should be adopted at all, is of unusual importance. This is because, even if the final purpose of the Phaedrus remains hidden, one of its themes is the nature

\footnotetext{
${ }^{76}$ This is not to say that White's approach to the Phaedrus "as a variegated exercise in ... metaphysics" is indefensible, so long as "metaphysics," already an anachronism when speaking of Plato, is understood in light of the fundamental tensions that are manifested in the dialogue (White 19932 ). Compare Nicholson's injunction "to be aware ... of the polyphony [in order] to understand why [Plato] wrote that way" (33; see also 1-2). This comes with its own risks, namely ignoring the principle of logographic necessity, which renders the interpretation of the Phaedrus a curiously disjointed activity (e.g., Nicholson 108).

${ }^{77}$ Jaeger appears to have been the first to explicitly doubt the possibility of achieving a true art of rhetoric (Jaeger 3.184). Such doubts are now common: e.g., Benardete (184-6), Burger (85-9), Griswold (191-201). White himself notes how Socrates' professed ignorance calls into question the possibility of this art, but he does not regard the conjunction of "inspiration" and "method" as problematic (White 1993 202, 263-5, cf. 226-7).

${ }^{78}$ Consider these statements: "The more they discuss rhetoric, the closer this ongoing account comes to situating the art of rhetoric within the totality circumscribed in the metaphysics of the palinode"; "But truth exists as a dimension of reality apart from fields of discourse. This otherness stands as a fixed certainty" (White 1993 265, 275).
} 
of good and bad writing, and consequently how to identify, analyze, and read such writing. Different methods of interpretation will produce different accounts of the nature of Platonic writing and the literary form known as the Platonic dialogue, its ends, and its means. This account will affect all subsequent readings of the Platonic corpus. In short, the method by which any particular dialogue is read presupposes an understanding of the nature of dialogue in Plato. But if an understanding of the Platonic dialogue further depends on an understanding of the Phaedrus, a circle is formed. Methodical study seems to presuppose the knowledge it seeks. Is there a method for establishing a method? What are its grounds? This problem is not external to the Phaedrus, but intrinsic to its discussion of the art of speaking. Socrates himself differentiates two "ways" (methodoi) of rhetoric. The "short and smooth" way of Lysias and Thrasymachus is characterized as a knack for rhetoric, born from natural skill and practice $(269 \mathrm{~d}, 272 \mathrm{~b}-$ c). The "long and difficult" way of the true art of rhetoric adds the criterion of knowledge, namely knowledge of the subject matter being discussed as well as of the soul to which speech is addressed (271c-272d). The easy way can never ascend to the principles that ground or make possible the persuasion it makes use of, and without a precise understanding of how persuasion is achieved it will never attain the perfection worthy of the title "art." But the way of the true art of rhetoric faces the same problem of method raised above: Socrates argues that dialectic can only be performed artfully if the speaker possesses knowledge of what is spoken about and of the soul he addresses, but then goes on to say that this knowledge can only be obtained dialectically (cf. 265c-266c, 270b-271c). Entry into this circle requires a non-methodical element. One could appeal to practice, whereby the student artlessly stumbles forward, correcting his understanding 
of the subject matter as he goes, by trial and error. But how will the student know that he has erred if he does not already possess some kind of knowledge? Socrates claims that knowing is recollection of what one already knows, so that there is an intuitive element in coming to know that supplements any "method," including dialectic.

This intuition is vested in the very opinions that Socrates interrogates and makes use of over the course of his conversations, for an opinion expresses in speech one's own experience of reality. One sense of the Greek word for opinion, doxa, is that it is what "seems best," meaning that an opinion is formed for the sake of some end, and more generally, for the sake of living and acting. Opinion is a link between speech and deed. Without the intuition of reality that is vested in opinion and action, any method would be but a sterile and unreal process justified only by its authority. Yet this intuitive grasp of how things are and whether one has erred remains an uncertain opinion and mere knackthe way of Lysias - until one can give the complete account that Socrates demands of the dialectician. The Platonic dialogue is consequently formed around the necessity that reasoning begins with and incorporates opinion, both the particular opinions espoused by the particular interlocutor as well as the common opinions that allow for dialogue. The written dialogue imitates the way by which knowledge can be recovered through opinion. Insofar as knowledge is obtained through opinion and conversation, the Platonic dialogue cannot be approached as the espousal of doctrine or the series of propositions in a proof, thinly veiled in the trappings of a drama. ${ }^{79}$ Rather, Plato's thought and intention is found in the arrangement or form of the drama itself and the interaction of his characters. Even when he writes in his own voice, he denies that words and writing can

\footnotetext{
${ }^{79}$ Gregory Vlastos's work is representative of this method, which often consists of rendering passages into the premises of syllogisms in order to clarify Plato's reasoning and meaning. This necessarily excises all dramatic and literary aspects from analysis (e.g., Vlastos 1991 132-56).
} 
contain the most serious thoughts, let alone truth. ${ }^{80}$ Nor is the unadorned opinion of Socrates, or whoever leads a given dialogue, ever given. Even when Socrates seems to express the highest truths, he always does so obliquely, by way of myth or simile, paradoxes, and puzzles, and these are frequently preceded by warnings: "But of course I am leaving out a great deal." ${ }^{, 81}$ Still, Plato cannot simply rebuff the easy way of reading that proceeds on the assumption that what is most important in a particular dialogue is already known or self-evident, or that certain arguments and concepts are sufficiently known from their counterparts in other dialogues (the most notorious example is the idea or eidos, and Plato's so-called doctrine of forms), or worst of all, from a second-hand exposition. To read in these ways is natural, for one can only read on the basis of one's own opinions and presuppositions concerning the meanings of words. But Plato does write his dialogues so as to confound this reliance on opinion.

In the first place, Socrates adapts his arguments to his particular interlocutor. $\mathrm{He}$ even tells Phaedrus that this adaptation is the basic principle of all forms of persuasion (271b, 271d-272b, 273e, 277b-c). His own arguments are always conducted ad hominem, not in the sense of attacking the character of the interlocutor (although the rhetorical use of shame is far from uncommon), but in that they address and are built around the actual opinions of the interlocutor. Moreover, persuasion is the leading of souls from one opinion to its opposite, a turning around and change of perspective attained, which Socrates accomplishes through the explicit refutation of opinion (261a262a). Rarely does a Platonic dialogue end without an interlocutor's opinions having been supplanted or refuted, and never without them having at least been shown

\footnotetext{
${ }^{80} \mathrm{PI}$. Letters (Ep.) 7.341b-e, 343a, 344c-d.

${ }^{81}$ Pl. R. $509 \mathrm{c}$.
} 
inadequate. The arguments that Socrates employs do not therefore plainly express his own opinion, but draw on common opinions that may establish agreeable premises for a persuasive argument (262a-b). These formal considerations also compound the broader problem facing the interpretation of any Socratic dialogue, which is Socrates' famous irony or dissembling. This irony is pervasive and conceals his inner thought and sense at any given moment, whether it is by feigning a pose, expressing false humility, saying the opposite of what he means, playing on the various meanings of words, contradicting himself, or formulating paradoxes. ${ }^{82}$ In the Phaedrus, this is understood through the discussion of playfulness as the demeanor befitting someone who is cognizant of the limitations of words for communicating knowledge and expressing the most serious thoughts. This playfulness is then extended to writing, such that the serious author must demonstrate his knowledge, which is greater than his words alone, by refuting himself (278c-d). Should a reader of Plato consequently take hold of some part of a dialogue by itself, believing he had taken hold of some real knowledge, he could be easily contradicted and refuted by another passage expressing the opposite sentiment.

The method for reading a Platonic dialogue cannot therefore be insensitive to the nature of dialogue, nor its presuppositions, and so cannot come from outside the dialogue. The Platonic dialogue must be read with openness, to allow the meaning to unfold itself rather than to impose meaning upon it. Plato compels the reader to become an active participant and think through the arguments, their relation to each other, the character of the interlocutors, and the work as a whole; the reader must exercise himself in the art of

\footnotetext{
${ }^{82}$ Friedländer dismisses any conception of irony as "a mere swapping of a Yes for a No," and sees it rather as the temperament of the pedagogue who sets himself at the same level as his student, which originates from "the living experience of the unknown" and is expressed most succinctly in Socrates' avowed ignorance (1.137-44). Vlastos similarly notes that Socratic irony cannot be reduced to making false statements, but is also "complex" in that "what is said both is and isn't meant" (1991 31).
} 
collection and division so as to engender an ethos of openness and to see the necessity and harmony that pervades the whole. The search for the meaning of the Platonic dialogue, understood as Plato's opinion, gives over to the reader's own contemplation and learning of the subject matter. ${ }^{83}$

In light of these considerations, the interpretation of the Phaedrus that is given here does not proceed on any assumptions about the development of Plato's thought. This is not because of the insufficiency of historical evidence for establishing anything more than a provisional chronology of Plato's writings,${ }^{84}$ but because the presence or absence of certain dramatic features, personae, arguments, concepts, or elements of style in one dialogue, regardless whether it is earlier or later, cannot explain the features of another without disrupting its integrity as a logographically necessary and complete whole unto itself. To read in this way would also repudiate the principle that speeches must be adapted to souls. ${ }^{85}$ Rather, this study aims to be an open-ended attempt to understand the coherence and argument of the text as a whole, as Plato intended it. At the same time, a dramatic reading of the sort proposed here cannot be taken for granted, particularly given its prevalence and legacy, and the interest of its proponents in the Phaedrus. ${ }^{86}$ The assumptions made by this way of reading, including the belief that

\footnotetext{
${ }^{83}$ Sallis 3.

${ }^{84}$ On the insufficient historical record and limitations of "stylometry" for dating the composition of Platonic dialogues, see Griswold (2002 130-3), Howland (206-11), and Rowe (1986 14).

${ }^{85}$ Rutherford is right that understanding of a given passage by drawing on similar passages in other dialogues can be helpful for understanding a given passage, but unless the "hazardous" nature of this approach is kept in mind, the point stands that the dramatic and philosophic unity of the single text is violated (Rutherford 1988 222-3).

${ }^{86}$ A large amount of the Plato scholarship in this vein can be traced to the influence of Paul Friedländer (see his account of the importance of dramatic action in Friedländer 1.158-61), and to some extent the influence of Schleiermacher's emphasis on esotericism (although esoteric readings do not of course imply dramatic readings). With respect to the Phaedrus, the influence of Friedländer is explicit (e.g., Pieper 3, 102) or can be traced through Jacob Klein and Leo Strauss to the monographs of Burger (77n24), Benardete, Griswold (1986 244n7), and Sallis (17). A notable exception is Rutherford, whose own dramatic reading stems from literary criticism (see Rutherford 1988217,$219 ; 1995243$ ).
} 
action and common opinion are philosophically significant, must be taken up and considered.

The criteria for artful rhetoric that Socrates provides in the Phaedrus may serve as provisional precepts of interpretation. Their real sufficiency as rules of art can only be established over the course of the interpretation itself. The first is the aforementioned logographic necessity, where every part of a text is necessary to all of its other parts and the whole. Every character, every speech, every question, every contradiction, and even every omission or silence, is a part necessary to understanding the dialogue as a whole. An interpretation must also consider the structure or form of the dialogue, as found in its setting, choice of dramatis personae, dramatic action, arrangement of arguments and topics, ${ }^{87}$ as well as its content, particularly the cogency and relevant implications of the arguments advanced, as well as the numerous mythological and contemporaneous references. Tracing Socrates' references, allusions, and misquotations can be significant for understanding the mood and meaning of a passage. Second, since the art of persuasion entails the power to lead the audience from one opinion to its opposite, apparent contradictions must be identified and resolved. This does not mean eliminating contradictions, but only understanding the reason for their occurrence, and thereby the aim of the argument as a whole. Third, since speeches are adapted to their audience, the actions and speeches of the dialogue must be considered in relation to the character of Phaedrus, as expressed in his particular opinions and passions. These are revealed over the course of his conversation with Socrates and in other works, Platonic and otherwise. Given that the Phaedrus is a conversation between Socrates and Phaedrus alone, and therefore that all of Socrates' speeches are formed in relation to this single interlocutor,

\footnotetext{
${ }^{87}$ See Appendix I: Synopsis of the Phaedrus.
} 
this principle implies that the unity of the dialogue depends on understanding the man Phaedrus. This, then, shall be the method of the following interpretation to the extent that a method can be clearly discerned and justified.

\section{Plan of the Dissertation}

In the first chapter, the principal questions of the Phaedrus are furnished through the character of Phaedrus, the circumstances of his encounter with Socrates, and the dialogue's elaborate setting. The principal problem considered by the Phaedrus is the nature of "showing forth," i.e., making things manifest, evident, clear, which has ethical and political implications. These are revealed in the character of Phaedrus and his understanding of the relation between erōs and the use of logos. Phaedrus has been greatly influenced by the climate of intellectual innovation in fifth-century Athens, which has produced in him an urbane passion for rhetoric and a curiously paradoxical ethic. On the one hand, he is moderate, even valetudinarian. On the other hand, speech itself is nothing but an instrument for self-gratification and novelty that depreciates the old symbols of order, including myths, Athens's sacred mysteries, and, history tells us, the law. Phaedrus's desires and understanding of speech blind him to the use of speech for the sake of truly understanding himself and the nature of things - he lives on the surface of things. Since Phaedrus's urbane grasp of the logos is produced through life in Athens, Plato pushes political life to the outskirts in order to examine the private experiences of the soul. The dialogue is set outside the city, in an enchanted grove under a plane-tree that symbolizes the metaxy, the erotic tension of reality that is hidden "in-between" the 
logoi. It will inspire the rediscovery of the true end of erōs that is necessary to renew the logos.

The second chapter shows how Plato uses the speeches of the "non-lover" to express the ethic of the urbane sophists and rhetoricians and their understanding of the logos. This "non-love" arises naturally from the political community but conceals the erōs behind speech. The speech of Phaedrus's friend Lysias, a famous speech writer, is a showpiece of the belief that words can be manipulated to any purpose, without regard for what really stands behind them. Lysias draws on the contradictory opinions and complex of desires that arise in the community, which allows him to affect a kind of balancing moderation that Phaedrus finds attractive. In the dramatic action that follows, Phaedrus's passion for Lysias' speech is shown to contradict the belief that speech and rhetoric can be freed from erōs: the logos cannot be separated from the actions that embody it, since the logos derives its power from the erotic or psychological link to what is signified. Socrates ironically demonstrates this point in speech by revising the speech of the nonlover. Since erōs is clearly marked as the source of disorder and irrationality, common opinion is unified in contradistinction to it and allows Socrates to improve non-love into a salutary conventionalism. But the purely rational and disinterested form of speech based on common opinion proves illusory because the non-lover is unable to account for himself or allow for his gratification as a non-lover. The logos must ultimately be grounded in a higher erōs that seeks to reconcile speech with reality so that it may be truly satisfied.

The third chapter interprets Socrates' great speech. Here, Socrates uses a myth to establish a fundamental psychology that shows how erōs grounds persuasion and the 
logos in reality. Erōs is the fundamental experience of soul in the tension of reality, the metaxy. Longing for what is always befitting and therefore truly satisfying, soul ecstatically moves itself towards what really is. Only the mind can perceive this eternal being by using reasoning (logismos) to intellect the form of things; logos is therefore subject to the soul's erotic desire for the complete disclosure of reality. At the heart of the erotic experience is the phenomenon of "showing forth," where the perception of beauty in its earthly manifestations generates such pleasure that the soul is led to believe those manifestations are true beauty. Separation from this gratification inspires erōs, which in the best case, the philosophic life, inspires the soul to search for the elusive truth and wisdom. This is the paradigm for love and persuasion because it is best able to light upon what is most desirable, while lower forms of erōs pursue the goods manifested in common opinion, such as honor and bodily pleasure. Socrates uses poetic and mythical imagery to show Phaedrus how the apparent madness of erōs allows the soul to break through the everyday or common logos to reality.

The fourth chapter shows how erös is in fact embodied in the life of the logos, and how it is Socrates' erotic art that guides Phaedrus to the true nature of artful speaking. Socrates and Phaedrus begin with the belief that rhetoric is omnipotent because it can persuade ignorant people on any subject without possessing knowledge. As in the second chapter, the presence of erōs behind the logos is evident. Phaedrus's love of logoi is rooted in his desire for endless and painless pleasure. The superficiality of this erōs and use of logos is revealed by contrast to the perfect dialectic required to truly discern the desired object, and how dialectic entails the erotic ascent to the complete vision of reality portrayed in the palinode. The rhetoric of Lysias and other famous 
professionals is constitutively incapable of real artistry because it manifests no regard for knowledge of its subject matter or of what is fitting for the soul of its audience.

Nonetheless, their efficacy in the fleeting persuasion of a crowd, in showing forth something to all by manipulating common opinions and passions, indicates that they have touched on a certain stratum of experience shared by every human soul. Unless the art of rhetoric as outlined by Socrates can grasp the nature of the whole, it will not supersede the demotic power of ignoble rhetoric. Philosophy is at the least in need of a public face or rhetoric, and may in fact deepen its understanding of soul, erōs, and logos in light of the power of the rhetoricians and their presumption of a universal logos.

The possibility of a truly universal and immortal logos is taken up in the fifth chapter. Plato ironically criticizes his own medium of writing in order to distinguish it from the superficial and instrumental writing and ethic that characterizes ignoble rhetoric. Socrates' Egyptian tale illustrates how this ignoble writing reduces memory to the recollection of sensible things and therefore knowledge to a commodity. Socrates dialectically ascends from this ignoble writing to a higher and universal $\log o s$ that reflects the transcendent nature of eternal being. This logos can only be revealed and passed on by leading the audience's soul to its own view of reality through the refutation of its opinions and what is manifest in mere words. In contradistinction to Socrates' strictly oral practice and private rhetoric, Plato's rhetoric addresses the whole range of souls and erotic experiences simultaneously by incorporating poetic manifestation of the whole and rhetorical gratification of the many. Only through Plato's art will Socrates' logos finally persuade the city and endlessly reproduce itself by generating in others an ethos of searching for what is truly fitting for the human soul. 


\section{PHAEDRUS}

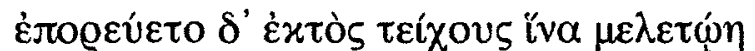
And he journeyed outside the walls in order that he might care for [the logos]

Only in hindsight does Phaedrus, which means Sparkling, Bright, or Beaming, appear to be an appropriate title. As with all of Plato's dialogues, the title alone can be said to be in Plato's voice, and so bears some consideration. Plato has made Socrates' interlocutor, Phaedrus of Myrrhinus, the ordering principle of the dialogue, and it is the man Phaedrus, not one of the various matters which he and Socrates discuss, that gives the dialogue its color and shape. The Phaedrus is not, in the first place, a treatise On Beauty, nor On Love, nor On Speech, for Plato's thoughts on these matters have been interwoven into this "Sparkling" dialogue. But the word Phaidros also signifies something more than just this one man. Perhaps it might mean sparkling like light (phaos) upon the morning dew (drosos), but it is more reliably related to phaidrunein, to cleanse, in the common sense of scouring with water to remove obscuring matter. ${ }^{1}$ Both Phaidros and phaidrunein derive from phaos and the verb phainein, "to show forth," which emphasizes the sensory experience of illumination. However, the abstract notion of showing forth in itself shows nothing except the sheer presence of itself as showing it is an empty experience, devoid of substance or content. Like all names and signs, phainein and Phaidros point beyond themselves to the thing signified, but this particular name also points back to itself as pure showing; this sign indicates that the showing is itself the object, not any particular thing. There is playfulness in the fact that the "showing forth" of the Phaedrus does not consist in some momentary vision or

\footnotetext{
${ }^{1}$ E.g., Hesiod, Works and Days (Hes. Op.) 752; Aeschylus (A.), Agamemnon 1109.
} 
revelation, but rather in the experience of the entirety of the text; were this not the case, there would be no need of a name, to say nothing of a book, in order to show something. The title is a sign whose meaning is only attained through the unfolding of the text and the subsequent memory that can invest that meaning in a single sign. The showing forth of the Phaidros must therefore be instantiated in what is particular, which in this case is the man Phaedrus of Myrrinhus who one day chanced upon Socrates and entered into a conversation with him that would reveal the nature of showing forth.

In the opening pages of the dialogue, the reader is introduced to Phaedrus, who playfully banters with Socrates as if they were lovers, but in doing reveals himself to be a selfish kind of lover. Moderate with respect to his body but a passionate lover of speeches, Phaedrus has developed a narrow view of both love and the relationship between speech and truth. Socrates shows him that unless he recognizes his passionate investment in the use of speech, he will never see speech $(\log o s)$ as anything but an instrument for gratifying his desires and never come to know himself and what truly moves him.

\section{Phaedrus of Myrrhinus}

The title of the dialogue refers to Phaedrus son of Pythocles of the Athenian deme or subdivision Myrrhinus. Likely born in $444 \mathrm{BC}$, he is approximately the same age as his friend, the famous speech-writer Lysias. Consideration of these characters in the Phaedrus, both as they are presented in the dialogue itself and in extant sources, deepens the abstract intellectual problem suggested by Plato's choice of title - what is a showing forth, and how might that be shown - into a more concrete ethical and political one. 
Historical sources corroborate the portrait of Phaedrus that is painted in the dialogue; his good family name and means, though modest, allows him to spend his time in a leisured manner and, along with his reputed beauty, enter the circles of other well-to-do citizens $(237 \mathrm{~b} 2)^{2}$

From a young age, Phaedrus spent his leisure engrossed in Greek literature and intellectual life. In the Protagoras, Phaedrus and many other youths gathered to meet Protagoras, in the hopes of learning from the sophist the art of speech, and also to learn from Hippias, a boastful and ostentatiously adorned sophist. ${ }^{3}$ The novelty and fame of these sophists proved to be more of an attraction than the old-fashioned moral teachings of Prodicus, whom Socrates found to be "all-wise" and "divine," yet Phaedrus later disparaged by likening his speeches to a book on the utility of salt. ${ }^{4}$ Phaedrus's love of speeches is also the inspiration for the entire series of encomia delivered in the Symposium, for which he is dubbed the "father of the speech" because the conversation is for the sake of his gratification. ${ }^{5}$ In his own speech, he reveals that he has been inspired by his reading of the poets and philosophers that place Eros before all other gods. However, his ready combination of Hesiod, who "says that chaos came to be first," with Parmenides, who argues for the natural priority of an eternal and unified principle of being, suggests that his speech benefits from these authorities in name alone. ${ }^{6}$ This clumsy invocation by Phaedrus betrays an interest in affecting intellectualism that comports with his admiration for rhetoricians in the Phaedrus. Indeed, his envy of Lysias' skill in speech-writing, for which he would give "more than a great deal of

\footnotetext{
${ }^{2}$ Lysias, On the Property of Aristophanes (Lys. 19) 15; Davies 200-1, 462-3.

${ }^{3}$ Plato, Protagoras (Prt.) 313c-e, $315 \mathrm{c}$; Lesser Hippias (Hp. Mi.) 368b-c.

${ }^{4}$ Prt. 315e-316a; Symposium (Smp.) 176 b.

${ }^{5}$ Smp. $177 \mathrm{c}-\mathrm{d}$.

${ }^{6}$ Ibid., 178b. cf. Hes. Theogony (Th.) 116 and Parmenides (Parmen.) frs. A24, B8, B13 [DK].
} 
money" mirrors young Hippocrates' feverish pursuit of Protagoras, for whose lessons he would spend all of his own money as well as his friends' $(228 \mathrm{a}) .^{7}$ The powerful command over speech possessed by both the sophists and rhetoricians has a hold over the young Athenians that cannot be underestimated.

In the first place, Phaedrus's delight in the novel teachings of the sophists has produced a general irreverence towards the customary things of the city alongside a rather selfish ethic. In the Symposium, Plato has Phaedrus elevate Eros, hitherto insufficiently praised, to a "mighty god," older than all others, such that the greatest blessings and rewards are bestowed upon the devoted lover (erastēs) and his beloved (erömenos). ${ }^{8}$ He transforms what Homer calls the divine "breathing of strength" that fills a warrior into an effect produced by love. ${ }^{9}$ He argues that Achilles was rewarded by the gods with an afterlife in the Isles of the Blest, rather than Hades, because he was a great beloved who sacrificed himself to avenge his lover. Indeed, Achilles' love of glory is entirely supplanted by his fondness for Patroclus, and the lover is rewarded for setting his beloved above all other bonds whether they be kinship, wealth, or office. ${ }^{10}$ Phaedrus can imagine no greater spur to courage - neither familial nor civic duty - than the reproachful gaze of the beloved. That the beloved assumes this commanding role is another peculiarity of Phaedrus's speech. Rather than erōs being a mutual and equal bond between peers, Phaedrus has interpreted it through the common Athenian practice of pederasty, where the beloved boy is pursued for his beauty and youth, and rewarded with

\footnotetext{
${ }^{7}$ Prt. 310d.

${ }^{8}$ Smp. 178a-b.

${ }^{9}$ Ibid., 179 b.

${ }^{10}$ Ibid., 178d.
} 
tutelage, gifts, and praise. ${ }^{11}$ Phaedrus is at pains to make clear that the gods are more beneficent towards the beloved rather than the lover, despite the latter being "more divine" and "filled with the god."12 The un-divine, un-enthused, and sober beloved is himself not erotically inspired, only feeling affection (agapē) towards his lover, while it is considered less blessed for the lover to be moderate rather than in love. ${ }^{13}$ This celebration of Eros shows itself to be instead a celebration of the beloved and of the benefits that he might receive on account of the inspired state of the lover (or lovers, since Phaedrus allows that a beloved might be pursued, and therefore benefited, by many). ${ }^{14}$ The purpose of Phaedrus's speech may be summarized as the elevation of the relationship between lover and beloved beyond other conventional bonds found in the city, and then in turn the subjection of that relationship to the benefit of the beloved. Phaedrus regards this self-serving speech as representative of what it means "to live beautifully.",15

Still, Phaedrus cannot be regarded simply as a well-heeled fop or dupe completely enchanted by the sophists and their epigone, for he also paid great heed to a parallel intellectual development, the art (technē) of medicine. His close friend Eryximachus, who appears with him in both the Protagoras and the Symposium, is a physician, and it is the medical advice of Eryximachus' father, Acumenus, that propels Phaedrus outdoors in the Phaedrus. In the Symposium, Eryximachus is the one who suggests an evening of speeches rather than the usual excesses of symposia, for the "strong drinkers" - all poets

\footnotetext{
${ }^{11}$ See Dover 1978 100-10.

${ }^{12}$ Smp. 180 b.

13 "For really the gods may honor most this excellence concerning love, although they more greatly wonder and delight and make well when the one being loved is fond of the lover than when the lover [is fond of] the boy" (Smp. 180a-b).

${ }^{14}$ Smp. $178 \mathrm{e} 2$.

${ }^{15}$ Ibid., $178 \mathrm{c} 7$.
} 
- are still recovering from the raucous celebrations of the previous night. ${ }^{16}$ His proposal is strongly seconded by Phaedrus, whose custom is to obey his friend concerning "medical speech." 17 This mutual flattery - one submitting to the expertise of the other, who in turn graciously proposes to gratify him - appears to be the sort of relationship that Phaedrus articulated in his speech. ${ }^{18}$ However, the sway that Eryximachus holds over Phaedrus, particularly through his elevation of bodily sōphrosunē (moderation or soundmindedness) to a cosmic principle that demands that orderly men be gratified in love first of all, casts doubt on whether the lover really does act at the behest of the beloved as Phaedrus imagines, and instead suggests a mutual admiration based on the moderation they have cultivated through medical knowledge. ${ }^{19}$ Indeed, these childhood companions leave the symposium once it descends into drunkenness. ${ }^{20}$

The strong hold that bodily moderation and the pleasures of sophistic speech exert on Phaedrus has made him irreverent and impious. These two strands are united in Phaedrus's depreciation of the other gods before Eros, whom Eryximachus in turn transforms into a force that harmonizes and orders the universe. The moderation of both men is derived from the new technē rather than the myths of old, and Phaedrus's disdain for ancient wisdom has a significant effect on both his life and the present conversation with Socrates.

Phaedrus is a man for whom signs, particularly those ancient ones most central to life as a Greek and especially as an Athenian, have become problematic. This was

\footnotetext{
${ }^{16}$ Ibid., 176a-c.

${ }^{17}$ Ibid., 176d. Eryximachus also expels the flute-girl, after he had secured agreement on the sobriety of the evening, although no one had as yet expressed any discomfort with her presence (Ibid, 176e).

Eryximachus the physician is thus responsible for an evening purged of ordinary intoxicants or what might arouse desire - little drink, no music, and no women.

${ }^{18}$ Ibid., $177 \mathrm{c}-\mathrm{d}$.

${ }^{19}$ Ibid., $187 \mathrm{~d}, 188 \mathrm{~d}$.

${ }^{20}$ Ibid., 223b-c.
} 
memorialized in an inscription on stone monuments, stēlai, recovered from the

Eleusinion in Athens, as well as in the defense speech of Andocides. Both show that

Phaedrus, amongst others, was charged with profaning the Eleusinian mysteries in 415

BC, shortly before Athens's ill-fated expedition to Sicily. ${ }^{21}$ This crime was punishable

with death, so Phaedrus and his alleged co-conspirators fled Athens, forfeiting their

property, and remained abroad until they were re-enfranchised ten years later, following

the decree of Patrocleides in $405 \mathrm{BC}^{22}$ Phaedrus's exile for this impiety looms over the

dialogue as a historical background to the philosophical problems discussed, giving

greater significance to the allusions to the Eleusinian mysteries found throughout. ${ }^{23}$

These ancient mysteries, maintained for nearly two thousand years, were a twin

set of annual secret rites dedicated to the grain and mother goddess Demeter, in which all

Athenians participated. Initiation seemed to signify participation in the perpetual

generation represented by the mother figure and the cyclical planting and harvesting of

grain. ${ }^{24}$ In the Homeric Hymn to Demeter, Demeter searches for and eventually recovers

${ }^{21}$ Inscriptiones Graecae (IG) $\mathrm{I}^{3}$ 422.229-30, 426.102; Andocides, On the Mysteries (And. 1) 15, 51; Thucydides, History (Th.) 6.27-9.

${ }^{22}$ And. 1.80.

${ }^{23}$ Yunis's claim, that "Plato ignored" the issue of Phaedrus's exile because of the time which had passed at the time of writing, is untenable (2011 8n18). The Sicilian expedition was "by far the most costly and finest-looking force ever assembled by a single Hellenic city" (Th. 6.31), and its ultimate failure ensured it would never be dissociated from the ill omen attributed to the profaning of the mysteries and desecration of the Hermes. That an innocuous and naïve man like Phaedrus unwittingly played a role in these important events is hardly insignificant to a book bearing his name. Nussbaum suggests that the implications of Phaedrus's impiety are best understood in light of what she believes is the historical impossibility of the dialogue, such that Plato set the Phaedrus in a mythical alternate history to emphasize the potential goodness of mania and erōs (212-3). But the dialogue is not historically impossible (see below), and its redemption of erōs is only possible and of interest in light of the problems generated by the base forms of erōs.

${ }^{24}$ George Mylonas' Eleusis and the Eleusinian Myseries remains the principal work on the mysteries and the archaeological evidence recovered at Eleusis. Further interpretation is provided in Karl Kerényi, Eleusis: Archetypal Image of Mother and Daughter. Douglas MacDowell provides a useful summary in his introduction to Andocides' On the Mysteries (MacDowell 1962). Mylonas traces the origins of the Eleusinian mysteries through legends of a cult to Demeter c. $1400 \mathrm{BC}(24)$. On the importance of the mysteries to Greek life, see Kerényi (7-12), particularly: "bios, life, [Praetextatus] declared, would become 'unlivable' [abiotos] for the Greeks if the celebration were to cease" (12). 
her daughter Persephone, whom Hades ensnared with the narcissus flower, raped, and took into the underworld. ${ }^{25}$ In every subsequent year, Persephone would spend the winter months in the underworld and then ascend in the spring, coinciding with the beginning of the planting season. The Greater Mysteries were said to be have been founded by Triptolemos in dedication to Demeter and held in Eleusis every fall, at the beginning of the harvest. They were celebrated by the entire city of Athens over nine days of fasting, emulating Demeter's fast from "nectar or sweet ambrosia" in grief over her lost daughter. ${ }^{26}$ The Lesser Mysteries were devoted to Persephone, who was referred to as the kore or maiden, and celebrated her springtime ascent from the underworld. These mysteries were held in Agra, a district that Socrates notes lies just past the setting of the Phaedrus (229c1-3). The Lesser Mysteries were said to have been founded so that Hercules, a foreigner, could be purified - particularly for his murder of the Centaurs and Chairon - and then later initiated into the Greater Mysteries, which would allow him to enter the house of Hades in order to complete his labors and escape. ${ }^{27}$ The Lesser Mysteries were thus a necessary preparation for the Greater. ${ }^{28}$

To profane these sacred initiation rites meant to take upon oneself the performance of what must necessarily be an imitation - serious or jesting - of the rites. In Phaedrus's particular case, the rites were profaned in the home of Pulytion by fifteen men, including Andocides and Phaedrus, Phaedrus's friend Eryximachus, and the famous general-cum traitor and friend of Socrates, Alcibiades. ${ }^{29}$ Although the purpose of the

\footnotetext{
${ }^{25}$ [Homer], Homeric Hymns ([Hom.] Hymn.) 2.1-32.

${ }^{26}$ Ibid., 2.47-50; Mylonas 259.

${ }^{27}$ Apollodorus, Library (Apollod.) 2.5.11-2; Mylonas 240. In Euripides' Heracles, the hero claims to have succeeded "for I was fortunate enough to see the sacred rites of the initiated" (600-15).

${ }^{28}$ Cf. Pl. Grg. $467 \mathrm{c}$.

${ }^{29}$ And. 1.11-15.
} 
profaning is unknown, the act indicates a breakdown in the customary solemnity granted to the mysteries, regardless whether the profaning was done in an attempt to achieve the highest mystery (epopteia, generally believed to be a sacred vision), ${ }^{30}$ or in mockery of the institution as one of superstition and vacuity. Once Alcibiades donned the robes of the Hierophant, the rituals of the mysteries had for him and his companions ceased to perform their traditional purpose. ${ }^{31}$

Dramatically, the conversation depicted in the Phaedrus occurs shortly before Phaedrus's exile in $415 \mathrm{BC}{ }^{32}$ This requires a brief explanation, given the ambiguous historical information and anachronisms found in the dialogue. ${ }^{33}$ Phaedrus was in exile from 415 until at least 407/6, and 404 at the latest. ${ }^{34}$ His friend Lysias still resides in the colony of Thurii, where he lived until 412, and Lysias' brother Polemarchus is still alive, whose death in 404 sets the lower bounds for the dramatic date, at 407-404 (257b4). This may be further narrowed to $407-405$, since Sophocles died in 405 yet is spoken of as if he were still alive (268c-269a). But Lysias is said to be "in town," meaning that he is visiting Athens, either from Thurii or his father's house in Piraeus, which allows for an earlier dramatic date, before Phaedrus's exile (227b3). ${ }^{35}$ This is preferable to the later date, 407-405, which places Phaedrus in Athens in an uncertain period. In the end, it is

\footnotetext{
${ }^{30}$ See Mylonas 274-8.

${ }^{31}$ William Furley points out that even if the profaning was light-hearted, "comedy is also a serious business," and gave insult to the cult of Eleusis (Furley 1996 31, 33n10).

${ }^{32}$ The historical sources can be found in Dover 1968 34-43 and Nails 314.

${ }^{33}$ The most important anachronism is Phaedrus's claim that Lysias is "the cleverest of those now writing" (228a), although his career as a professional speech writer did not begin until after his family had lost its fortune to the Thirty Tyrants in 404. Socrates also speaks of raising Gorgias "from his slumber" (267a), although Gorgias did not die until about 380 - nineteen years after Socrates' own death (Nails 156-8).

${ }^{34}$ Only two exiles, Alcibiades and Axiochus, were known to have returned to Athens by 407-6, and Alcibiades was only recalled on account of his skills as a general (Nails 19).

${ }^{35}$ Nussbaum seems to overlook this so that she may argue that the dramatic date of the dialogue is deliberately anachronistic (212-3); see note 23 above. Rhodes unconvincingly argues that "Lysias is in town" simply means that Lysias had walked up from the port of Piraeus, which had become a suburb of Athens proper; such an everyday occurrence would have hardly warranted comment (Rhodes 422-3).
} 
the dramatic date of the Symposium that sets the upper bounds of the dramatic date in the Phaedrus - assuming that Plato was concerned with providing a coherent dramatic chronology for these two dialogues. The Symposium can be definitely dated at February 416, when Agathon won his first victory for tragedy, ${ }^{36}$ and is likely earlier than the Phaedrus, since Phaedrus would not ask for encomia to Eros after hearing Socrates' great speech. The conversation of the Phaedrus therefore occurred in 416 or 415 . If the latter, the summer setting means that it occurred immediately before the accusations of impiety were leveled, in the midst of preparations for the Sicilian expedition (230c2). This expedition signaled the resumption of hostilities between Sparta and Athens, following the six-year Peace of Nicias. Phaedrus's easy life of idle leisure is, unbeknownst to him, about to be darkened by the winter of Persephone and the harsh realities of political life. The "happy summer day" ${ }^{37}$ of the Phaedrus is a brilliant but momentary efflorescence.

\section{Outside the City Walls}

The action of the Phaedrus is performed rather than narrated and so occurs without recollection, in contrast to many other Platonic dialogues. Only as direct a showing forth as is possible in writing will here suffice for Plato. This unstated mimicry of direct speech is the stepping beyond itself characteristic of all writing, and is dramatized in the opening scene.

The Phaedrus opens just inside the walls of Athens so as to illustrate how Socrates is tempted into an uncharacteristic departure outside the city walls. The first words of the dialogue signify an abiding theme of temporality. Socrates has caught sight

\footnotetext{
${ }^{36}$ Nails 314-5.

${ }^{37}$ Nicholson 23, following Wilamowitz.
} 
of Phaedrus, Shining, and so inquires "whither and whence?", indicating that the younger man's present state is not one of rest but of motion. Socrates thinks it important to learn of his friend's origins as well as his destination, so that cause and purpose are joined by Phaedrus's present desire.

Phaedrus responds that he has, since morning, been in the home of Epicrates, formerly the home of Morychus. It was "there" (ekei) that the famous speechwriter Lysias regaled him and his companions with speeches (227a3). Phaedrus once again found himself in the company of rhetoricians. The proximity of the home to the temple of Zeus did not seem to have any effect on the character of its inhabitants, for Morychus was a wealthy man given to extravagance and gluttony, and consequently became the frequent butt of Aristophanic jokes. ${ }^{38}$ Aristophanes also ridiculed Epicrates, although the comic poet did not live to witness that man's greatest transgressions of taking bribes and using his ambassadorships for profit, for which he was sentenced to death in $392 .{ }^{39}$ The fact that Lysias himself wrote a speech accusing Epicrates of these offenses no doubt informed Plato's decision to place these men in friendly relation in the Phaedrus, perhaps as a reminder to Athens that there is no direct correlation between wealth, rhetorical skill, and good character. ${ }^{40}$

The time Phaedrus spent with these men, over "there," evokes a common poetic figure. Many other personae in Greek literature had also once traveled from "here" (enthende) to "there" (ekei), to that other place below the earth, the realm of Hades that

\footnotetext{
${ }^{38}$ Aristophanes (Ar.), Acharnians 887; Peace 1008; Wasps 506.

${ }^{39}$ Ar. Ecclesiazusae 71; Demosthenes, On the Embassy (D. 19) 277-8. For further sources see Nails 13940.

${ }^{40}$ Lys. Against Epicrates (Lys. 27) 1-9.
} 
lies across the boundary of death. ${ }^{41}$ Plato frequently uses this euphemism to no less striking effect. ${ }^{42}$ Phaedrus sat toiling in Hades alongside the other shades of men and has now arisen for the sake of a walk; were it not for the needs of the body, Phaedrus might have remained there indefinitely. The time spent "there" did not seem to be toilsome to Phaedrus, however, and was simply a passing of the time, literally "rubbed away" (diatribe $)(227 \mathrm{a} 4)$. This willingness to so spend his leisure is the object of Plato's implied critique; Phaedrus's turn of mind and choice of companions have cast him into a kind of hell, which is compounded by the apparent pleasure he has experienced, for it shows that he has not recognized it as a hell. Plato's inversion of the spatial orientation of "here" and "there," casting Athenian people and places - and, in other dialogues, institutions - as the underworld, could only be called subversive, although it might prove to be the to benefit of Phaedrus and the reader alike once Socrates' analysis of common opinion in Athens is further developed.

Socrates' interest in Phaedrus's time "there" is focused on the presence of Lysias, rather than Epicrates. He notes that Lysias "is in town," presumably visiting from Thurii. Lysias is not rooted to the city in the same way as Socrates, who rarely leaves (230d). Indeed, Lysias' father Cephalus had been invited to Athens by Pericles, on account of the family's wealth. ${ }^{43}$ Despite, or because of, his limited legal rights as a "metic" or alien resident, particularly exclusion from courts and the assembly, Lysias developed a strong

\footnotetext{
${ }^{41}$ E.g., A. Suppliant Women (Supp.) 228-30; Euripides (E.), Hecuba 418, Medea 1073-4; Sophocles (S.), Antigone 76, Oedipus Tyrannus (OT) 776.

${ }^{42}$ E.g., Pl. Apology (Ap.) 40e-4lc; Phaedo (Phd.) 64a, 68a-b; Grg. 525c, 527a; R. 330d. Note the variety of contexts in which the euphemism for Hades can be employed, often pejoratively, as in the case of the Gorgias, where it refers to litigation and law courts as well as unthinking hedonism (471e-472a, 501b). Voegelin further notes that often Plato will subsequently invert this euphemism to indicate that the source of truth lies over "there," beyond the realm "here," which is now likened to hell (Voegelin 3.108, 114-6). The double meaning of death is discussed below.

${ }^{43}$ Lys. Against Eratosthenes (Lys. 12) 4, 20; Davies 589. See also PI. R. 330 b.
} 
interest in political matters by writing speeches, mostly forensic, and fostering relations with the democratic party. ${ }^{44}$ Lysias' eloquence, then, was not a trifling hobby, but a skill for the protection and advancement of his interests. Rhetorical skill could mean the difference between life and death in terms of legal suits or currying public favor, and it was especially useful for Lysias, given his precarious legal position. Indeed, Lysias became a professional speechwriter only after his family's substantial assets were seized and his brother Polemarchus executed by the Thirty Tyrants, an oligarchic regime installed in Athens by Sparta, in $404{ }^{45}$ For Phaedrus, however, neither necessity nor want of means has fascinated him with Lysias' skill. The true nature of Phaedrus's desire to become, like Lysias, a master of the art of speaking is only revealed to the reader, and perhaps to Phaedrus himself, over the course of the dialogue.

Phaedrus attempts to persuade Socrates to join him in his walk with the promise of telling him about what occurred at Epicrates'. Phaedrus will be a messenger from over "there," if Socrates has the leisure (scholē) to follow. Socrates denies that he has any leisure, but playfully declares that learning what Lysias said is, quoting Pindar, "business that surpasses lack of leisure [ascholia]" (227b). Socrates' lack of leisure seems to refer to his customary practice of conversing, often in the market, with whomever he comes across, purportedly in the pursuit of wisdom. ${ }^{46}$ The song quoted by Socrates, Pindar's Herodotus of Thebes, similarly begins with the poet interrupting his duty to the god with a civic duty; he begs leave from Delos, for whom he was writing an ode to Apollo, so that he might sing the praises of his compatriot's victory in the chariot race. Socrates has also

\footnotetext{
${ }^{44}$ Lys. 12.52-3, fr. 7 (Against Hippotherses in Papyri Oxyrinchus, 1606 fr. 2). On Athenian law regarding metics, see MacDowell 1978 76-8, 82-4, 240-2.

${ }^{45}$ Lysias gives his account in Lys. 12 . Plato himself notes the potential gravity of the situation that necessitates rhetorical prowess (Ap. 38c; Grg. $511 \mathrm{~b}-\mathrm{d}$; Theaetetus [Tht.] 173a).

${ }^{46} \mathrm{Pl}$. Ap. 23b-c; Xenophon, Memorabilia (Xen. Mem.) 1.1.10.
} 
described his ascholia as a duty assigned by the god, and later tells Phaedrus that his leisure is limited because he is consumed with self-knowing, as prescribed by the inscription at Delphi (229e-230a).$^{47}$ Has Socrates set aside this quest for self-knowledge in order to find out about the diatribe ef Lysias and Phaedrus? It is more likely his conversation with Phaedrus will somehow coincide with his ascholia, just as Pindar claims that his praise of Herodotus will also serve to honor Apollo. ${ }^{48}$ Socrates' duty, to Athens as a whole if not simply to his friend, will in some way contribute to his professed business of knowing himself.

Socrates playfully asks Phaedrus, "What? Do you not believe that I alongside Pindar would put these things above lack of leisure [ascholia], to hear the pastime [diatribēe] of both you and Lysias?" (227b). In this gentle mocking of Phaedrus - gentle because Socrates does indeed wish to hear what the two spoke of - Socrates suggests that only a great thing like the victory of Herodotus, which drew Pindar away from Apollo, could today distract him from his usual business. The similarity between Herodotus and Phaedrus, however, ends with their shared willingness to forgo wealth in pursuit of their respective desires - glory for Herodotus, rhetorical skill for Phaedrus (228a) ${ }^{49}$

Phaedrus's amateurish pursuit is but a dim reflection of Herodotus' athletic prowess. Plato deliberately draws this contrast with Phaedrus's walk "among the colonnades [dromoi]" alongside Herodotus urging his team around the race course (dromos) (227ab). Phaedrus's desire to walk in the country, in order to refresh himself from the exertion of his time over "there," is an anemic moderation compared to the toils that Herodotus

\footnotetext{
${ }^{47}$ Ap. 33c.

${ }^{48}$ Pindar, Isthmian Odes (Pi. I.) 1.6-7.

${ }^{49}$ Ibid., 1.50, 67-9.
} 
endured. ${ }^{50}$ Plato here marks the increasing honor bestowed, in Athens, on eloquence and the power of persuasion; Phaedrus is one of the many who have been lured into a new realm of contestation of dubious merit.

Although he is no Herodotus, Phaedrus is not entirely submerged in his activities in Epicrates' home, and has not succumbed to the idleness and gluttony of the home's previous owner Morychus. His physical fatigue draws him out of "there," and it is Acumenus' medical advice that leads him to cross paths with Socrates on his way outside the city. Socrates goes even further, saying that, for the sake of hearing of the diatribe of Phaedrus and Lysias, he would walk to Megara and back - a total distance of nearly seventy miles - as the physician Herodicus prescribed (227d). The pleasant and comfortable stroll that they are embarking on pales next to the arduous regime of that devotee to physical health. Socrates once again gently mocks Phaedrus. But Socrates is not simply criticizing Phaedrus's lack of zeal - in fact, Herodicus is roundly criticized by him in the Republic for contributing to "the bad and shameful state of education in a city" that, being accustomed to luxury and licentiousness, is in constant need of treatment and drugs. By devoting himself to the care of the body, Herodicus lost sight of any other purpose for living. ${ }^{51}$ For the sake of what does Phaedrus live that he must so moderate his life? It is certainly not to indulge in bouts of eating or drinking. Phaedrus is neither an infamous epicure, nor a champion charioteer, nor an ascetic physician, nor a renowned rhetorician or sophist. In contrast to these men, Phaedrus's careful moderation has meant that he has not achieved anything exceptional.

\footnotetext{
${ }^{50}$ Ibid., 1.41-2.

${ }^{51}$ R. 405a-406e; cf. Prt. 316d-e. Socrates prefers the ancient Asclepius, who "said that he did not have leisure to be sick and it is not profitable to live this way, putting one's mind to diseases and neglecting the work that lies ahead."
} 
Socrates' bemused remarks set a playful tone for their short journey outside the city. The journey proceeds through the pursuit of each man for the other in the jesting mode of lovers, Phaedrus's use of written speeches, the introduction of the problem of myth and the nature of truth, and finally culminates in Socrates' quest for self-knowledge and description of the extra-logical source of his inspiration. The entire journey is animated by each man goading the other into pursuing him. Phaedrus first attempts to have Socrates walk with him by promising to tell him of his diatribē. When Socrates teases him with his reference to Pindar's ascholia, Phaedrus tells him to take the lead instead, and Socrates is forced to ask again about the diatribe. Phaedrus happily gives a preview of the subject, since he believes it would be suitable for his older friend: he and Lysias passed their time with a speech that was "about love [erōs] in some way I do not know" (227c). Phaedrus is apparently confused because the beautiful beloved (erōmenos) is pursued not by a lover (erastēs) but by a non-lover (mēe erōn, literally "one who does not love"). Lysias' thesis holds two apparently opposite things together, "for he says one must gratify the non-lover rather than the lover." As one commentator notes, rhetoricians frequently employed such paradoxes in their "display speeches" so as to demonstrate their power of persuasion, and Phaedrus is suitably impressed by Lysias' "refinement." ${ }^{.52}$ Sensing this, Socrates immediately moves to disrupt Phaedrus's enchantment by exposing the deception in the speech. He recognizes that Lysias' speech will inevitably favour the wealthier and younger man; if only Lysias had written speeches that equally benefited the poor and old, they "would be urbane and friendly to the public [dēmos]," and particularly beneficial to Socrates himself (227d). Lysias' rhetorical skill

\footnotetext{
${ }^{52}$ Rowe 1986136.
} 
could help Socrates as a lover, but is at present only directed to his self-interest - which betrays its pretensions to be free from love.

Phaedrus responds to Socrates' love-struck pose by adopting the guise of an amateur, unable to worthily relate from memory the words of "the most clever of those now writing" (228a). Through this false humility, Phaedrus would stoke Socrates' desire by coyly withholding from him the object of pursuit. It is at this moment, however, that Phaedrus reveals that he would rather be able to imitate Lysias' speech than have a stack of money, and Socrates decides to expose Phaedrus's ruse rather than further pursue him. Socrates' subsequent diagnosis brilliantly brings together the themes of their journey in anticipation of the greater one that encompasses the majority of the dialogue. Socrates reverses the game of pursuit by calling to witness his personal knowledge of Phaedrus, and enters into what Rowe observes is a parody of the forensic style: Socrates hides Phaedrus in the demonstrative pronoun ekeinos, "that man," as if he were being prosecuted for his deception..$^{53}$ Foremost among Socrates' pieces of evidence is that because the speech was written (graphesthai) - it did not escape Socrates' notice when Phaedrus mentioned this (227c5) - Phaedrus could have Lysias repeat it, and he could review it, many times over, "looking upon what things he greatly desired" (228b). This power peculiar to the written word would allow Phaedrus to "know thoroughly" (exepistasthai) the contents of the speech, provided it was not too long, and expedite his desired imitation of it. Phaedrus then "journeyed outside the walls in order to care for it," practicing it until he chanced upon a man who was "ill with respect to the sound of speeches [logoi]" and whom he "joined in [performing] the Corybantic rites." Here, the calculating desire (epithumia) of "that man" Phaedrus, carefully memorizing Lysias'

${ }^{53}$ Ibid., 137. 
speech piece by piece, gives way to the frenzied dance of the corybant who has an ear only for the tune of his goddess. ${ }^{54}$ This forensic parody charges that Phaedrus, having found an appropriately susceptible man, would take advantage of him by feigning restraint. Indeed, it is characteristic of Phaedrus to adopt a humble and moderate pose, which would be familiar to his friends.

Plato uses this playful banter to betray the desire and intent of Phaedrus, whose coyness immediately arouses the suspicions of the reader. Socrates' own suspicions are cued by his knowledge of Phaedrus, as he prefaced his accusations by claiming, "if I do not know [agnoein] Phaedrus, I have also forgotten myself. But really, neither of these two is [the case]" (227a). At first glance, this claim is straightforward in the assertion that there is some quality to Phaedrus that Socrates is quite familiar with and in fact betrays his pose. What is peculiar, however, is the formulation of the proposition that his knowledge of Phaedrus depends on his memory of himself. This knowing of Socrates (gignōskein) differs from the knowing that Phaedrus pursues (epistasthai) in his memorization of Lysias' speech. ${ }^{55}$ In this particular case, Socrates' ability to remember

\footnotetext{
${ }^{54}$ To "join in the rites of the Corybant" renders the single verb sunkorubantiein (Phdr. 228b7; cf. Rowe 1986 138, de Vries 41). The corybants worshipped the earth mother Cybelle, often celebrating her in a frenzied dance accompanied by rhythmic music. This cult was later associated with Dionysus, the god of wine and the revel, who was purported to have been initiated by Cybelle herself. On the exclusivity of the corybants' inspiration, see Linforth 1946b 139-40; cf. Pl. Ion 536c.

${ }^{55}$ Although each is frequently rendered "to know," gignōskein connotes "coming to know" and hence "to recognize," and is more often used in reference to human beings rather than other objects of study. Knowledge of oneself is never described by Plato as a matter of epistēme, which usually refers to the knowledge possessed by craftsmen or through study. Plato's use of the two has puzzled scholars. Griswold argues that each verb signifies a distinct mode of knowing, the gnostic and the epistemic, in accordance with mythical and technical understanding (Griswold 1986 5-6, 200-1, 232). Gnostic knowing entails the pre-knowledge of the whole that Socrates depicts in the palinode as the condition for all coming to know as well as the that which makes possible the technical, "quasi-mathematical" and "rule-governed" knowing of epistême $\bar{e}$. Although attractive in its differentiation of these two modes, the terminological distinction neither has any etymological basis (de Vries 1988 162; gnosis as a higher mysterious knowledge seems an advent of the New Testament, e.g., Corinthians 1 8.7, 10, and Ephesians 3.9), nor does it seem supported by Plato's usage in the palinode. Ultimately, the complete knowledge that Socrates seeks alongside self-knowing as gignōskein is described as epistēme $(247 \mathrm{~d}-\mathrm{e})$.
} 
himself and Phaedrus implies some sort of self-knowledge or self-possession through memory. Without constancy of the subject, Phaedrus could not be a consistent object of knowledge or recognition. ${ }^{56}$ Socrates' recognition of Phaedrus and of himself are mutually dependent, for Socrates remembers Phaedrus when he recognizes him, which entails recognizing that he himself has seen Phaedrus before. Coming to know and learning, Socrates will later claim, are matters of recollection rather than acquisition. This personal knowledge seems to depend more obviously on prior experience.

The calm gaze with which Socrates sees himself, placing himself in the third person, betrays his pose of erotic frenzy. The true crime that Phaedrus commits is not against a frenzied man, but rather against the man unwilling to listen, whom Phaedrus would compel to listen "even by force" (228c). Socrates thus adopts for himself not one but two poses, the corybant maddened by speeches and the unwilling listener. He is at once desirous to the point of illness and dispassionate with respect to Phaedrus's speech. The introduction of this second pose allows him to further amplify Phaedrus's injustice and the extent of his friend's desire - he paints the defendant as a man that is the complete opposite of what he claimed to be. What he shows Phaedrus is two men animated by the desire for speeches, rather than just the corybant, and that it is Phaedrus's desire for a listener that first sets this back and forth pursuit into motion. Socrates shows Phaedrus the type of man he truly desires, a man so possessed by Phaedrus's speech that he would follow wherever his beloved should go. This also shows that Phaedrus is ignorant of Socrates, since he mistook him, albeit playfully and with Socrates complicit, for the corybant he so desires. This entire opening conversation is directed by Socrates to show Phaedrus something of the nature of his desire, both for

${ }^{56}$ See Tht. 154a-b, 157a, 158e-159d. 
speeches and companions, and it shows Phaedrus to be the opposite of what he believes himself to be. Phaedrus is not simply a beloved, but a lover as well.

This mutual and playful erotic pursuit ends with the disclosure of Lysias' written speech. When Phaedrus attempts to simply give a summary of the parts he remembered, Socrates disarms him by telling Phaedrus that he is not interested in hearing this dull imitation, but only the original words of Lysias, who by means of his writing "is also present" (228e). Phaedrus, in order to give the appearance of possessing Lysias' rhetorical power, hides the source of his inspiration, but Socrates spies the scroll that his friend holds in his left hand under his cloak: "you hold the speech $(\log o s)$ itself.",57 Although Socrates' knowledge of Phaedrus had made him suspicious from the beginning, he willfully joined him in playful pursuit, perhaps to illustrate by deed Phaedrus's deception and the desire that underlay it. Socrates not only succeeds in having Phaedrus read the speech, but he also confronts his friend's posturing. Having rid Phaedrus of this, he draws their physical journey to a close. They will be able to follow the logos only once they have identified an appropriate site for rest, and ceased the motion of their bodies. This site will, at Socrates' suggestion, be along the Ilissus and off the road they currently travel, which they had followed upon the medical advice of Acumenus. Although the physician's prescription was "fine," according to Socrates, it is not appropriate for the reading of the logos $(227 \mathrm{~b})$.

Nonetheless, Acumenus' advice has prepared Phaedrus for the final stage of their journey, as he is barefoot just like Socrates: "It is fitting [eis kairon], so it seems, that I

\footnotetext{
${ }^{57}$ This scene is undoubtedly meant to evoke a similar one in Plato's Charmides, or vise-versa (155c-e). It is also tempting to see Socrates' words as referring not only to Lysias' particular speech, but to the logos as a whole, the nature of logos itself; Lysias' paradoxical show-piece represents the nature of logos, with all that the faults of Lysias' speech would imply about the logos itself.
} 
happen to be unshod; indeed you always are" (229a). Although Socrates' habit may mark him as unusual in the city, he is ready to travel outside of it; Socrates has no need for the artificial comforts that would now impede Phaedrus. On this occasion, therefore, Phaedrus's care for bodily health serves to bring him outside of the customs of the city and interrupt his fixation on the speech of Lysias. That their lack of footwear is "fitting" or "in season" (eis kairon) of course depends on the setting of the Phaedrus, and marks its first explicit connection to the conversation of the two men. Beyond the painting of a "not unpleasant" pastoral scene, Plato is able to use the setting as a font of literary allusion and to communicate a drama that occurs outside the explicit words and arguments of his characters. Phaedrus in particular seems to need reminding of the action behind the $\log o s(229 \mathrm{a})$.

\section{The Myth of Boreas and the Business of Socrates}

The approach towards Lysias' logos first makes its way through the mythical stories (muthologêma) that surround the chosen reading place. Socrates here indicates a preliminary distinction between logos and myth that is in stark contrast to the one Phaedrus would draw, for it depends on the results of his search for self-knowledge rather than on reasoning based on common expectations derived from sensory experience. ${ }^{58}$ With the tall plane-tree in the distance, Phaedrus asks Socrates whether it is not "here" that Boreas, god of the north wind, reputedly seized Oreithuia (229b). He is referring to

\footnotetext{
58 "Mythology" or muthologia appears to be a term invented by Plato, and occurs in the Phaedrus (243a4; see its cognates muthologèma, "mythical narrative," and muthologein, "to tell myths" or "to mythologize," at 229c5 and 276e3) and in four other dialogues (Hp. Ma. 298a4; Lg. 680d3, 752al; Statesman [Plt.] $304 \mathrm{dl} ; R$. 382d1, 394b9). The word is a compound of muthos and a derivative of logos, logios, which indicates a person concerned with speaking (but may play on logion, an oracular pronouncement). Plato's use of the word has a curiously paradoxical effect, given the contrary meanings attributed to muthos and logos, as discussed below.
} 
the old story that Oreithuia, daughter of the Athenian king Erechtheus, was playing along the Ilissus when Boreas descended upon her. ${ }^{59}$ Boreas raped her and made her his wife, and she bore him daughters and two winged sons. ${ }^{60}$ While Phaedrus is doubtful whether this is true (alèthēs), his recollection of it during this walk with Socrates indicates that it certainly made an impression. The place appears to him a suitable one for maidens (korai) to play in, given its charm and transparent waters, and so he presses Socrates whether "it was therefore really here [that Boreas seized Oreithuia]?" (229b). The violence of erotic desire, as that which compels the soul outside of its comfort and innocence, and which was implied by Phaedrus's willingness to compel Socrates to listen to him, has now erupted. Perhaps Phaedrus, frustrated by his failure to "exercise" his memorized speech on Socrates, suggested this particular site for reading because it brought to mind Boreas' compulsion of the maiden (cf. 228c, 228e). Phaedrus's understanding of love seems to be dualistic, where the frenzied passion of the lover is opposed to the flight of the apparently frightened and moderate beloved. Phaedrus's recollection of this contrast between divine violence and human moderation is in keeping with his speech in Symposium, although he may have here unwittingly appropriated for himself the role of Boreas rather than the beloved and pure maiden. The reading of Lysias' speech, however, will not take place in the shadow of Oreithuia's rape, regardless whether Phaedrus desires or fears such a portentous coincidence of the scene for his recital. Socrates refutes Phaedrus's belief that the scene is a suitable location for the myth.

\footnotetext{
${ }^{59}$ Herodotus, Histories (Hdt.) 7.189; Apollod. 3.15.2.

${ }^{60}$ A pollod. 1.9.21. The two sons, Zete and Calais, known for their pursuit and killing of harpies, were fated to die "whenever chasing they may fail to capture [their prey]." Later tales tell that Boreas made a gift of two immortal horses to Erechtheus for the seizing of his daughter (Nonnus, Dionysiaca 37.155).
} 
This refutation sheds some light on the differences between the two men with respect to the customs of the city as well as their conception of truth and understanding. Socrates acknowledges that "it is said" that this is the site of Oreithuia's capture, but dismisses this rumor on account of other evidence (229b). The actual site, he tells Phaedrus, is "two or three stadia [ 350 to 500 meters] further down, toward the crossingplace into Agra; and there is somewhere some altar of Boreas on the spot" $(229 \mathrm{c})$. The vagaries in this description ("two or three stadia," "somewhere") indicate that Socrates has not visited the spot himself, but his certainty of its existence is well founded. Herodotus recorded that a shrine to Boreas was dedicated following the second Persian invasion. Prior to the battle of Salamis in 480 , an oracle had advised the Athenians to sacrifice to Boreas, and as the Persians sailed along Magnesia and Euboea, en route to Athens and Salamis, two storms struck and destroyed nearly half their fleet. ${ }^{61}$ Socrates remembers the memorial to this great Greek victory, upon which Athens's current power was founded, but Phaedrus, some twenty-five years his junior, has never bothered to learn about it and has "not noticed it" $(229 \mathrm{c})$. For Socrates, what determines the true location of Boreas' rape of Oreithuia is not simply hearsay, but the presence of a civic memorial; the actual myth itself may be of little interest to Socrates. Phaedrus's ignorance reveals that, within a generation, both the location and meaning of the memorial have been lost. As a consequence, Phaedrus further misunderstands Socrates' correction of him and assumes it to mean that Socrates may in fact "suppose this mythical tale to be true" (229c). Socrates' response is masterful in how it manages, all at once, to slight the sophists, instruct Phaedrus, establish a necessary ground for philosophy, and otherwise deflect the question. He says that he would be not at all "out of place" (atopos) among

\footnotetext{
${ }^{61}$ Hdt. 7.188-90, 8.14.
} 
the sophists or "wise men" (sophoi), were he to distrust such stories (229c). He could appear wise by claiming that, while Oreithuia played with Pharmaceia (from pharmakon, "drug"), a wind arose and threw her down upon some nearby rocks, and that she "came to her end" (teleutēsasan) as a result of being carried away from there. Or, alternately, for the account (logos) also claims this, she was carried away "from the Areopagus," the ancient court that tried capital cases and was by legend founded on the site of Ares's trial for the murder of Halirrothius, son of Poseidon, who had raped his daughter (229c-d). ${ }^{62}$ Such rational explanations, however, would require a "clever" and "toilsome" man, because it would also be necessary for him to likewise "correct the form [eidos] of Centaurs, and again of the Chimera, and [there] would flow upon [him] also a throng of such sorts as Gorgons and Pegasai and some other inexplicable natures of marvelous speech both multitudinous and out of place [atopiai]" $(229 \mathrm{~d}-\mathrm{e}) .{ }^{63}$ The problem would not necessarily be that such a man distrusts these tales, but that he would do so "on account of the likelihood [eikos] of each," which Socrates calls a "rustic sort of wisdom" (229e). When Phaedrus asked Socrates about the truth of the matter, Socrates suspected that the conception of truth held by Phaedrus and some of the sophists - Protagoras' dictum that "man is the measure of all things" being a case in point - is that truth lies in the eikos, that is, in relation to one's own experience or what is commonly attested. ${ }^{64}$ Form, eidos, is understood entirely through its basic meaning of a visible "look." Mythical tales are

\footnotetext{
${ }^{62}$ D. Against Aristocrates (23) 65-6; Arist. Rh. 1398b25; Apollod. 3.14.2.

${ }^{63}$ "[Things] of marvelous speech" renders teratologōn, as Rowe's "portentous" does not capture the two senses of religious omen (terata) and speech (logos), both of which are so important to the Phaedrus (LSJ 1776).

${ }^{64} \mathrm{Cf}$. Tht. 152a ff. Protagoras can be related to the sophoi that are mocked here only by the shared assumption that an individual's sense experience is the standard for truth and knowledge. Protagoras is nowhere described as descending to the vulgar concerns of those who dispute mythical stories on the ground of their improbability and indeed is willing to employ his own myth in Plato's Protagoras (Prt. $320 \mathrm{c}-324 d)$.
} 
disputed because they do not accord with ordinary experience: no one has actually seen the wind rape and impregnate anything, and so the "strange" or "out of place" tale of Oreithuia must be false. The truth of the logos depends on the corroboration of sensory experience. The distinction between myth (muthos) and logos arises out of the fantastic appearance of the myths, and Phaedrus's, and the sophists', use of the two words implies a deep-seated mistrust of ancient stories, for both muthos and logos originally meant "words," "stories," and "speeches." In Homer, muthos meant authoritative speech, and did not imply a fantastic tale, although those too could be told authoritatively. Logos meant calculating speech, and consequently it and its verb legein often connoted deception. $^{65}$ The modern distinction, even opposition, between muthos and logos is therefore coextensive with a depreciation of traditional authority, and not simply disbelief of fantastic tales. $^{66}$ Without the authority of the ancients, a modern logos must rely on new standards, although Socrates' ridicule of the toilsome sophist indicates that merely substituting rationalized hearsay is no improvement.

\footnotetext{
${ }^{65}$ E.g. Homer, Iliad (Hom. Il.) 3.188, Odyssey (Od.) 4.452, 9.335; Hes. Th. 27-8. See Beercroft 53-4 and Lincoln.

${ }^{66}$ Diskin Clay locates the ascendancy of logos and the discrediting of muthos in Herodotus and Thucydides (Clay 210-1; see also Gerard Naddaf's introduction in Brisson 1998 vii-x, and Voegelin 2.239-53). Herodotus gathered many stories and often disputed the more fantastic ones, and used the word muthos, albeit only twice, in a depreciative manner (Hdt. 2.23, 2.45). In Thucydides, the modern distinction is evident (e.g., Th. 1.21-2). Logos, for the historians, does not seem to convey any particular authority (Morgan 2000 19-20). The attribution of greater truth and authority to logos appears to have been a separate development that began quite early, by the time of Heraclitus (Heracl. fr. B1, B50 [DK]), and sometimes sharpened into an attack on muthos (e.g., Xenophanes fr. BI [DK]), although philosophy continued to employ "myths" as late as the $5^{\text {th }}$ century (e.g., Parmenides [Parmen.] fr. B1-2, B10-13 [DK]). In Plato's time, though, his invention of mutholegesthai (see note 58 above), "to tells myths" or "to mythologize," would have a paradoxical effect on his contemporaries' ears (see Protagoras' dichotomous use of muthos and logos in Prt. 320c, 324d). "To mythologize" could mean either: to make myths out of clear speech, i.e., to obfuscate and obscure; or to make logoi out of myths and so clarify ancient stories; or to somehow accomplish both at once. This compound means that Plato to some extent restores the archaic meanings of muthos and logos and reconciles them, but he does not refute the modern distinction (he is often described as complicit in, if not the principal authority for, making this dichotomy [Brisson 90; Lincoln 363; Morgan 2000 24, 27]). Despite the willingness of Plato's Socrates to employ myth, Socrates remains dedicated to the use of logos in the sense of calculation (e.g., 249 cl).
} 
Rather than boldly stating the truth or falsity of things, Socrates begins from the humble position of his own ignorance. He lacks the leisure of the clever "wise men" that spend their time disputing the likelihood of mythical stories, and the "cause" (aitios) of this, he says, is that "I am not somehow able, in accordance with the Delphic inscription, to come to know myself [gignesthai]" (229e). Asides from this business consuming Socrates' time, it is not obvious why the business of "looking to myself" ${ }^{\prime 67}$ would preclude the rendering of mythical stories into a likely logos. A further complication is that Socrates expresses his need for self-examination in mythical terms, since he is puzzled whether he is "some beast more complex and Typhonic than Typhon, or some living thing both quieter and simpler" (230a). On the one hand, Socrates may be the horrifying, enormous, and multi-formed monster that attempted to overthrow Olympus, or on the other hand, he may be something of calm simplicity. ${ }^{68}$ The tension between these two poles describes the problem of Socrates' existence, but only the pole of complexity and being Typhonic is described mythically. Socrates uses myth, what is out of place from the everyday, to disrupt Phaedrus's complacency; Socrates is also "out of place" and unlikely (cf. 229c-d). Yet the simple and calm animal has no mythical analogue, either creature or god; Socrates' self-examination must contemplate something beyond the multitude of forms found in muthologèma. To conduct this self-examination in the method of the sophists, by way of likely logoi, would only mire him in an infinite

\footnotetext{
${ }^{67}$ Skopo ... emauton should not be construed in terms of the customary distinction between public and private. Socrates' looking at himself does not imply a direct concern for idia or the business of the household, and has in fact come at the expense of such things (see $A p .23 \mathrm{~b}-\mathrm{c}$ ).

${ }^{68}$ Typhon, son of Gaia and Tartarus, had a human torso and extremities composed of a multitude of snakes, and was of a size that dominated the horizon, touching the stars while reaching from the east to the west (Hes. Th. 821-68). Later stories describe in greater detail his usurpation of Olympus: he succeeded in chasing the gods into Egypt, where they took animal forms, before he was destroyed by Zeus, who appeared "from the sky in a chariot drawn by winged horses" (Apollod. 1.6.3).
} 
succession of physiological forms (eidoi) ${ }^{69}$ Were he simply a chaotic and ever-changing multitude, the Delphic inscription would be ridiculous. His self-described "ignorance" (agnoein) inheres in this tension or problem, and his awareness of its parameters implies that his ignorance is not absolute (230a). Phaedrus, however, as Socrates implies by describing the sophistic version of myth, does not look to himself and is even prevented from doing so by his desire to inquire about the "truth" of things in such a pedantic manner. Unlike Socrates, Phaedrus is unaware that he might be something complex, a problem; he has not taken the inscription at Delphi seriously.

This problem of knowing oneself, however, does not mean a retreat into oneself. Socrates refuses to offer opinions on the truth of things, saying that it would be ridiculous "to look upon the things belonging to others" while he does not yet know himself $(229 \mathrm{e}-$ 230a). But this has not prevented him from coming to know Phaedrus, knowledge of whom he said depended on his self-knowledge. Self-examination seems to require participation in conversation with friends and others; he must live in the logos that binds himself to other human beings and their common institutions and customs (nomoi). Until Socrates is able to resolve the tension that he perceives in himself, he will act in the customary way with regard to the myths, that is, he will be persuaded (peithomenos). The elusiveness of this response - peithomenos also means "trusting" and "obeying" - is significant for two reasons. First, Socrates again juxtaposes his adherence to custom with Phaedrus's irreverence. Phaedrus's interest in disputing myths is trivial, and perhaps even worrisome given his own apparent enjoyment of them (here and in the Symposium) - he finds pleasure in their falsity and separation from reality. Dispelling myths in the

\footnotetext{
${ }^{69}$ Socrates elsewhere says that such an inquiry would simply result in reductive physiological explanations, like those of Anaxagoras, rather than the disclosure of a true cause (Phd. 97b-99a).
} 
manner of the sophists is not pertinent to his self-examination, and so Socrates finds no purpose in thus subverting customs that he knows, given his reference to the shrine, are important for public life. ${ }^{70}$ Second, Socrates' "being persuaded" may imply obedience, but it does not imply conviction or understanding about these matters. This distinction will prove to be of great importance in the later discussion of the art of rhetoric and critique of Lysias. At the moment, it is sufficient to note that whatever Socrates' real understanding of the myth of Boreas and Oreithuia, it is certainly not in terms of the common opinions that the sophists dwell in.

Socrates' parody of these sophists serves to not only instruct Phaedrus about the true and the likely, but also about his interest in the written logos of Lysias. Plato's shift from the pursuit of Lysias' speech to this discussion of myth is abrupt but not unrelated. Socrates' addition of "Pharmaceia" to the myth - a hitherto unknown figure in Greek literature $^{71}$ - deepens the medical theme of the prologue by expressing not the restorative powers of that art, represented by Acumenus, or its potentially arduous and even consuming nature, represented by Herodicus, but a deadly side effect. Oreithuia's play with Pharmaceia establishes a relation between medicine and death, which is as yet only implicit in the advice of the aforementioned physicians. Death occurs only in the rationalized logos of the sophists, not in the muthologèma in which Oreithuia is brought among the gods and gives birth to semi-divine children. Her divine ascent in the myth is translated by Socrates into her "coming to an end," teleutēsasa. The immortality that is accomplished in myth is beyond the sophists' comprehension. There is nothing beyond the death of the body, and although the pharmakon may work as a "remedy" in order to

\footnotetext{
${ }^{70}$ Contra Rowe 1986142.

${ }^{71}$ Clay 213.
} 
preserve the body, it might also work as a "poison" and so aid in the body's dissolution. ${ }^{72}$ The clever but "rustic" wisdom of the sophists renders Oreithuia's violent ascent beyond the body and mortality into what can be recognized by the senses. She reaches her end (teleutē), but it need not simply be physical death.

Plato also uses teleutein to describe Phaedrus when he took hold of Lysias' written speech: "Phaedrus at last [teleutōn] borrowed the book" (228b). There, the participle form indicated Phaedrus was in a state of completing, where the satiation of his desire means that it comes to an end and as such dies. In that case, desire was sated by the possession of speech in a fixed and physical manner that is only possible with writing. Socrates later refers to the logos as a pharmakon, both Lysias' speech and generally $(230 \mathrm{~d} 6,270 \mathrm{~b} 4-9,274 \mathrm{e} 6,275 \mathrm{a})$. The overt implication is that the logos, as Pharmaceia or a pharmakon, is dangerous as well as restorative. Logos as a pharmakon might prepare one for an ascent into divinity.

In fact, Socrates says that he believes the sophistic versions of myth to be "graceful in some other way" (229d). He used one such version to communicate a warning to Phaedrus in a manner that Phaedrus finds attractive, but then supplemented that warning by undermining the sophistic rationalizations. The culmination of this is not a return to the original myth, but a recovery of something worthy in it. This recovery depends on the revision of the myth by the likely logos, and then incorporating its warning so as to join death to the mythical ascent while at the same time redeeming death as a completion. This development of the meaning of myth indicates to Phaedrus that he is to pass beyond the sophistic conceptions of logos and alètheia to which he has been accustomed.

\footnotetext{
${ }^{72}$ Phd. 63d8. See also LSJ 1917.
} 


\section{$I V$. Initiation into the Lesser Mysteries}

The walk from over "there," in Epicrates' home, proceeded along the Ilissus and has now come near the crossing-place into Agra. Phaedrus also indicated that the planetree towards which they walk lies over "there" (ekei) (229d). Phaedrus and Socrates are between these two places, two other worlds, and having ascended through the common stories and interpretations of the myth of Boreas and Oreithuia (whether it is "here" [enthende]) to disclose the possibility of a higher purpose for the logos. Plato's careful depiction of this scene, as well as a number of allusions in his characters' conversation, evokes the traditional journey taken by initiates into the Lesser Mysteries of Eleusis. The journey of Phaedrus and Socrates transfigures this initiation, suggesting that these sacred rites and the examination of the logos somehow share in the same nature. They too will cross over into higher secrets, albeit in a manner foreign to Eleusis and into secrets hitherto unattainable.

Reconstruction of the actual rites involved in the Lesser Mysteries remains speculative, although they began with fasting and a collective walk to Agra. Once there, the initiates imbibed the kykeōn (a potion of fermented grain seen as preparatory for communion with Persephone), made sacrifices to Persephone, were fanned by the liknon (a winnowing instrument that separated the wheat and chaff), and at some point were veiled in anticipation of a vision. Purification by water, either by immersion or having a draught poured over oneself, was performed recurrently. ${ }^{73}$

The physical journey of Phaedrus and Socrates likewise signals the beginning of their purification. Phaedrus's ascent from Epicrates' home, over "there," is set within the

\footnotetext{
${ }^{73}$ Kerényi 61; Mylonas 239-43, 260n160.
} 
context of Persephone's rites and her own annual ascent. Phaedrus describes what he supposes is the site of Oreithuia's rape as one being suitable for "maidens" (korai) - the sacred symbol of the Lesser Mysteries. The myth of Boreas seizing Oreithuia is a parallel of Hades' seizing of Persephone. Socrates' mention of Agra and his inclusion of the centaurs in the list of mythical creatures for which he has no leisure recalls Hercules' final labor and need for purification. Socrates now finds the pharmakon of Lysias' speech before him and ready for consumption. The significance of these allusions to the Lesser Mysteries allows a reinterpretation of Phaedrus's journey from Athens.

Beginning with Phaedrus's departure from Epicrates' home, the journey is concerned with the logoi found in the city, particularly those of the rhetoricians and sophists, and their intoxicating effects. Phaedrus's innocent dalliance with such pharmaka has seen him seized and brought into an underworld, as was Persephone. Only his inclination towards bodily health brought him up, and now his fortuitous meeting with Socrates has set him on the path towards purification and initiation. The need for purification is indicated in Socrates' parody of the sophists; Phaedrus is persuaded by a sophistic conception of truth as eikos, which has come at the expense of old myths and practices of civic significance. Phaedrus is ignorant of the depth of the logos, in how it reaches beyond being an instrument for diatribē and gratification, but touches on political matters, public institutions, and even self-knowledge. He is ignorant of how the logos encompasses both meanings of pharmakon, and can be both remedy and poison. The remedying of this ignorance must begin with Phaedrus being cleansed of the underworld that is the sophists' logos. 
This initiation of Phaedrus contains great irony, given that he was exiled for profaning the mysteries of Eleusis and that Plato has him converse with Socrates shortly before being forced to flee Athens. Yet the purpose of Plato's allusions to the mysteries cannot simply be to berate Phaedrus for his irreverence, since he and Socrates do not participate in those mysteries and instead partake in novel, albeit related, ones. On the one hand, Plato brings attention to Phaedrus's crime, but on the other hand reenacts that crime himself by mimicking the mysteries and invoking its symbols over the course of the dialogue. The sacred rites performed in secret by the Hierophant are now performed in a public writing; and just as all Athenians were privy to the deeds that occurred at Eleusis, now all readers are privy to those of the Phaedrus. If initiation into the mysteries consists solely of ritual actions, the showing of sacred things and the speaking of words, Plato presumes to reveal all of these in the Phaedrus. Eleusis, having become an object of ridicule, is not cast aside but reinterpreted in the way Socrates reinterpreted the myth of Boreas in order to rediscover what truths were contained in the ways of the ancients. ${ }^{74}$

Once the need for Phaedrus's purification and initiation is clarified, the two men come to the end of their physical journey. Socrates does not smoothly conclude his explanation of why he does not investigate myths in the way of the sophists, and then turn to Lysias' speech. Instead, he interrupts the conversation in order to announce their arrival under the plane-tree, "in-between [metaxu] the logos" (230a).

\footnotetext{
${ }^{74}$ In the Phaedo, Socrates says to Simmias, "And I also venture that those who founded the mysteries for us were not slight men, but in reality long ago intimated that whomever may arrive in Hades uninitiated and incomplete will lie in mud, but he who arrives there [ekeise] having been purified and initiated will dwell with the gods" $(69 \mathrm{c})$.
} 


\section{The Metaxy}

The plane-tree appears before Socrates and Phaedrus in the midst of the likely speeches of the sophists and Socrates' quest for knowledge. The tree proves to be a place that is wonderfully situated not only near the boundary of Agra but on the limits of ordinary experience. The reading site is the first of several experiences in the Phaedrus of the tension of the in-between, the tension of the metaxy. ${ }^{75}$ Here, it is a place of inspiration situated between Athens and the unknown destination of their conversation. Surveying the grove, Socrates exuberantly swears, "by Hera, a fine stopping place" (230b). The oath proves appropriate, as it was Hera who was responsible for Hercules' madness, and Socrates proceeds to depict the place in a most unusual manner that amazes Phaedrus. ${ }^{76}$ Having just parodied the likely logoi about myth, Socrates is now effusive about the details of the scene and their mythological associations. In the center stands the "tall" and "wide-spreading" plane-tree (platanos), gently shading the soft grass and a "most graceful fount" flowing with cool water. Below the tree sits a shrine of maiden (korai) figurines dedicated to some Nymphs and Achelous, the many-formed river god from whose horn Hercules was said to have fashioned the horn of plenty. ${ }^{77} \mathrm{~A}$ fresh breeze carries a sweet smell while the summer hum of cicadas resounds. Socrates has depicted the scene as one stretched between the heights of the plane-tree and an agnus bush and the overflowing life springing from the earth and water underfoot. Even the mythical creatures that Socrates mentioned earlier - the Centaurs, Chimera, Gorgon, and Pegasus - seem to have likewise sprung from this joining of the water god and the mother

\footnotetext{
${ }^{75}$ On the general nature and function of metaxy in Plato's work, see Friedländer 1.41-3.

${ }^{76}$ Apollod. 2.4.12.

${ }^{77}$ Hes. Th. 340; Soph. Trachiniae 9 ff.
} 
figure of Hera, ${ }^{78}$ whose name Socrates elsewhere says means "air."7y These two poles of air and water, which together form a source of generation, are not the only elements of the metaxy that Plato has introduced here.

Several themes of Socrates and Phaedrus's journey converge here in the figure of the tree. The plane-tree is a steadfast center to the element of flux and motion in the scene; because of its presence Socrates and Phaedrus are neither buffeted by the divine wind of Boreas, nor made hot by the summer day, nor directly underneath the bright light of the sun. It is this middling realm provided for by the plane-tree that makes it a spot suitable for resting and reading. The fittingness of the physical scene presented by Plato indicates that it is neither a superficial gloss nor a simple dramatic device to bring the characters together. The tree shows that there is an end to the journey, one that will at least provide temporary rest before Socrates and Phaedrus must return to the city, as well as an end in the sense that it allows for the unfolding of the remainder of the dialogue. As the plane-tree looms over Socrates and Phaedrus, so does the setting over the whole dialogue, providing its playful and inspirational tone while at the same time holding together the currents of separation and otherworldliness. When the setting does fade into the background, it soon reasserts itself between the monologues and the conversation, always calling to mind that Socrates and Phaedrus are "in-between the speeches," in the metaxy, and that there remains a broader whole that grounds any given discourse. The dramatic setting joins together and justifies otherwise detached speeches, and so fastens

\footnotetext{
${ }^{78}$ The Centaurs were born from a cloud impregnated by Ixion (Pi. Pythian Odes 2.21-48; Apollod. Epitome [Epit.] 1.20); the Chimera and numerous other beasts from the sea-dragon Echidna (Hes. Th. 297-322); the Gorgon from the sea-monster Keto (Ibid., 270-4); and the Pegasus sprang from the corpse of the Gorgon (Ibid., 280-1). Pindar sang of the great efforts made by Bellerophon to tame Pegasus with the bridle given him by Athena (Pi. Olympian Odes [Ol.] 13.63).

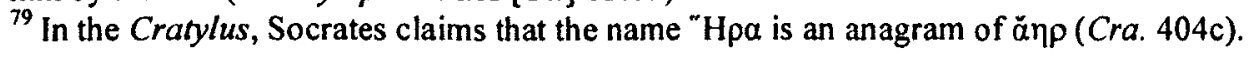


what might appear to be detached words - innocent play or diatribe - to an underlying reality. ${ }^{80}$ The playful pun on Plato's name with the plane-tree - the genitive Platōnos and platanos - grandly appropriates the same role for the author. ${ }^{81}$ In his use of the planetree, Plato foreshadows the puzzle that he has somehow written in a way to show what is "in-between the speeches," in the same way that Socrates does in live dialogue.

This perception of being in-between is not given simply by arriving at a tree, but rather comes from the immediate dramatic context. For Phaedrus, the sight of a large plane-tree and its shade would be to him nothing wondrous, yet he is astonished by Socrates' account of the spot because he is confronted by what is contrary to his own experience. Socrates has prepared this astonishment through their discussion about the truth of the myths and self-knowledge. His dismissal of the sophistic account of myth may have given Phaedrus the impression that he was entirely uninterested in myth, while his depiction of himself as perhaps something Typhonic revealed that there might remain some use for myth. At this very moment, when Socrates describes himself as somewhere in-between Typhon and simplicity, he is prevented from continuing by the appearance of the metaxy. The force of the metaxy is here not simply an interruption, but quite literally something in-between the logoi concerning myth, something hidden or otherwise obscured by them. Phaedrus has proved to be unperceptive of this, for he still dwells entirely in the logos, holding to the belief that the sophistic eikos logos will give a true account of myth. Phaedrus's engrossment with such logoi has rendered him oblivious to

\footnotetext{
${ }^{80}$ Planinc 136-7, cf. 129-30. Planinc argues that the plane-tree represents the omphalos, the navel of the world that binds together the cosmos. The omphalos at Delphi was a sacred stone, and although nowhere in ancient Greece is the omphalos described as a tree, there were numerous sacred trees (e.g., the oak at Dodona) which Planinc argues are manifestations of the omphalos.

${ }^{81}$ The genitive Platōnos (from Platōn) means "of" or "from" Plato, used to describe origin, and so the force of the pun is to make the author the source or even father of both this particular grove and all that occurs underneath it. See Zaslavsky 1981.
} 
the metaxy, and so Socrates' overwrought description of the reading site effectively puts into speech for Phaedrus the nature that he does not perceive. This does not make the scene a source of inspiration for Phaedrus, but he is brought to wonder (thaumazein) at this strange man who interprets the scene for him:

O wondrous man [thaumasie], you seem to be someone most strange [or: out of place, atopotatos]. For you speak artlessly, like a visiting stranger and not from this country; this comes from you being out of town, though you neither leave home going beyond the border [lit. into what is beyond the border, eis tēn huperorian], nor do you seem to me to go outside the wall at all. (230c-d)

Phaedrus begins to experience in their relationship the metaxy and the wonder that Socrates found in the scene, which he elsewhere describes as the beginning of philosophy. $^{82}$

What might have been an otherwise tranquil and healing place for reading is transformed by the corybantic and "ill" Socrates, who confronts Phaedrus as a new source of excitement and inspiration. If the plane-tree, said by some to be the Tree of Hippocrates the Asclepiad, really does have healing powers, its inspirational effects indicate a conception of health far beyond Phaedrus's limited concerns. ${ }^{83}$ Phaedrus's life, primarily concerned as it is with the uninterrupted enjoyment of pleasures, now faces the wondrous spectacle of Socrates' "ill" and frenzied life, where the death of Oreithuia is no certain wickedness (258e). But if Phaedrus thinks Socrates is some rustic who communes with nature, the older man tempers his enthusiasm: "the country and the rocks do not wish to teach me anything, but the human beings in town do" (230d). The grove under the plane tree may excite his senses with its manifest beauty, but he finds no knowledge or understanding in this vision. His rare journey outside the city walls is,

\footnotetext{
${ }^{82}$ Tht. $155 \mathrm{~d}$.

${ }^{83}$ Ferrari 198732.
} 
after all, for the sake of a logos that was written in the city. It is because Socrates is "a lover of learning," as he describes it, that he will follow Phaedrus "throughout Attica" in pursuit of the speech of Lysias (230d-e). The logos as a pharmakon only appears to have drawn him out of his customary ways, for he spends his time inside the walls of Athens speaking with whomever he might come across. Speech may hide or distort nature and reality, but without it, nature remains an obscure and perplexing source of inspiration. The Phaedrus is itself immensely urbane, boasting an amazing breadth of allusion to political speeches, mythology, lyric poetry, encomia, medicine, the visual arts, and so on. Although Socrates seems to echo the exhortation to country life in Hesiod's Works and Days, the simplicities and virtues of nature and country life are not simply taken hold of, but must be recovered through art. ${ }^{84}$ The dialogue cannot be conducted in the full light of the sun. ${ }^{85}$

This short journey of Socrates and Phaedrus outside the walls of the city has been a preface to their journey into Lysias' logos. What began as a comfortable country stroll for Phaedrus, incited by his habitual interest in speeches and inclination towards medical prescriptions, has been transformed by Socrates. Seeing that the irreverent Phaedrus has only just arisen out of the underworld of his urbane sophistic company, Socrates dons a pose of deep and frenzied interest in the logos of Lysias so that Phaedrus may himself don his usual pose of a beloved who gratifies himself by enslaving his lover. This opposition between beloved and lover reflects Phaedrus's fascination with Lysias' speech - it seems to provide precisely the spell that a non-loving and moderate beloved would

\footnotetext{
${ }^{84}$ Jaeger argues that the very form of Hesiod's poem, which adopted the high style of Homer to exhort his brother to the life of the farmer, indicates that Hesiod was similarly aware that a return to the old and simple ways of country life was not straightforward and that a repudiation of the sophistications of urban life was not possible (Jaeger 1.73-5).

${ }^{85}$ R. 515e-516b.
} 
desire so that he would receive all the favors a lover may bestow, without being possessed by the compromising and disruptive madness of love. Phaedrus believes that he is the non-lover of the speech but does not recognize that his love of the logos has brought him under the spell of Lysias. Phaedrus has dallied with a powerful pharmakon that will bring about the very opposite of what he desires. He believes that should he become the sick and corybantic lover played by Socrates, he would come to the very same end as Oreithuia - to be a lover would for him be the death of the moderate beloved whom he believes receives all benefits from love. The favors that Lysias' speech promises to the non-lover are the reward for such a narrow conception of love; they are the likely business and interest of love that all are aware of, in contrast to those mythical accounts of love that are too fantastic to be believed. Phaedrus's conception of love and the way he uses speech are thus intimately bound together in his way of life - his interest in rhetoric, his inclination towards the moderation prescribed by physicians, his skepticism towards myth, his irreverence towards the ancient ways of Athens, and not least of all, his comportment to his fellows. Although Phaedrus and Socrates are outside the city, they have not abandoned it and life in it.

Phaedrus is susceptible to Lysias' logos because he is ignorant of any love that is outside the likely; what is corroborated by his own experience and understanding about the relationship between a lover and beloved - the extraction of favors - is for him the simple truth of the matter. His understanding of what constitutes truth prevents him from endeavoring to know himself. Socrates recognizes this in Phaedrus because he has not forgotten himself as someone who lacks knowledge of himself and so is a problem for himself, lying somewhere in-between the Typhonic and simplicity. Socrates takes this 
metaxy that he finds in himself and presents it as the metaxy under the plane-tree because Phaedrus does not recognize the metaxy in human life. Socrates is already an object of interest for Phaedrus, as both a friend and a fellow enthusiast of Lysias' logos, and by making himself an object of wonder, he is able to lead the younger man into the problem of self-knowledge and the nature of logos. Unlike his time in Epicrates' home, Phaedrus will now follow the logos with someone who recognizes that it is a drug that can both heal and harm. With Socrates' guidance, even the drug of the sophists and rhetoricians may be used as a remedy for Phaedrus's accustomed ways. 


\title{
THE URBANE SPEECHES
}

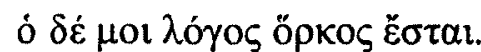 \\ And for me the speech will be an oath.
}

Socrates described himself to Phaedrus as a frenzied and erotic lover of speeches, while the speech of Lysias presents itself as a remedy for lovers and a poison for erōs itself. The promise of this peculiar remedy is that once it has brought to light the shameful, worthless, and generally harmful nature of erōs, the listener will come to know the illness and so be able to deter its progress and engage in relationships with a sound mind (söphrosunēe. Socrates has placed himself in the very role of the lover that Lysias' speech is designed to combat. Given that this symmetry is a contrivance of Plato, why has the work of Lysias in particular been chosen as the object of Socrates' mad erös? Lysias' reputation as a foremost speech-writer only complicates the issue further, for why would Plato put in the mouth (or on the pen as it were) of such a man a speech that is of a private and frivolous nature, when he will, after his return to Athens in 404, write for the serious business of the law courts? What is the significance of this foray by a writer of public speeches into the genre of love literature? It is here that the problem of unity in the Phaedrus is first raised, for if the dialogue is intended to be simply an exploration of the theme of love, it would seem contrary to that purpose to have a political writer treat the subject. Likewise, if the dialogue's theme were simply rhetoric or logos, Lysias' unusual thesis - indeed, this so-called Erotikos is the only extant example of Lysias' nonpolitical work - would serve little purpose beyond being an example of poor writing, a purpose that could just as ably be served by work from an author's accustomed genre. These unsatisfactory explanations compel the interpretation to consider whether there is 
not a more essential connection between the substance of the speeches, the dramatic loveplay of Socrates and Phaedrus, and the development of the subjects of rhetoric and logos that occur later.

Socrates will later call the first two speeches of the Phaedrus "urbane," asteios, literally "of the town" (astu), and accuse them of "urbane foolishness" because of the cleverness and sophistication of Lysias' thesis, namely that one ought to give favours to a non-lover rather than a lover (242c). But "urbane" also signifies the relation of this thesis, and logos generally, to the political community and its opinions. The urbane speeches, and the thesis of non-love, show how rhetoric is able to deceive, separating speech or words, logos, from reality, by appealing to the variety of desires and opinions that might be found in an audience. Through his actions and ironic speech, Socrates reveals that this non-love that separates speech from action and desire is selfcontradictory, ultimately impossible, and consequently accompanied by an unsatisfying ethic.

\section{The Written Speech of the Non-Lover}

The defence of a paradoxical thesis was the height of fashion in Greek oratory and a potent advertisement for the talents of a speechwriter. ' Lysias' thesis is of this sort: he claims that the beloved should bestow favours not upon a lover, but rather upon a nonlover. Lysias writes this exhibition piece (epideiktikos logos) in his familiar forensic style, which employed a vocabulary, argumentative forms, and moral appeals that would be effective before the diverse jury of the Athenian democracy. The jury was composed of citizens drawn by lot for a particular case, and was usually made up of the poor and

\footnotetext{
${ }^{\prime}$ See the discussion of epideixis in Arist. Rh. 1.3, 1.9.
} 
old. ${ }^{2}$ Anticipating the potential diversity of his audience, Lysias preferred to create a concrete character suited to the tastes of the audience rather than to make use of "psychological generalizations." " His style as a whole aimed at the cultivation of an appearance of respectability and moderation. ${ }^{4}$ The need for relatively simple characterizations conveyed in prosaic terms also informed the dualism found in his speeches, often contrasting a person's words and deeds, or a culprit and his victim. ${ }^{5}$ Evidence of Plato's parody is seen in the exaggeration of these features of Lysias' style. What structure can be found in the speech is found in couplets that contrast the lover with non-lover, or a promise of the lover with its inevitable failure, or a common understanding of the lover with its opposite. ${ }^{6}$ These couplets are then followed by a summary and then conclusion that argues for the selection of a suitable non-lover. Lysias begins with his thesis, which is itself formed in antithesis:

On the one hand you know about my business, and have heard that I think it to be advantageous for us that these things come to be; but on the other I think it fit [lit. is worthy, axioun] that what I ask not be refused on account of this, that I do not happen to be your lover. (230e-231a)

The thesis implies that the non-lover's proposal is of the sort that occurs between lover and beloved. The later confirmation of this sexual innuendo gives credence to Socrates'

\footnotetext{
${ }^{2}$ Citizens received pay for jury duty. For the makeup and selection of the citizen jury, see MacDowell 1978 33-5.

${ }^{3}$ Dionysius Halicarnassus (D.H.), Lysias 11, 13, 19; Dover 196876.

${ }^{4}$ D. H., Lysias 19.

${ }^{5}$ See Dover 196870 . Lysias' use of antithesis was sufficiently pervasive to draw criticism from Theophrastus, a late commentator on oratory (D. H. Lysias 14).

${ }^{6}$ Shorey argues the "mechanical" transition kai men de ("and indeed") is here overused in parody of Lysias' style (Shorey 131-2), to which Burger adds höste ("so that") and eti de ("and yet") (Burger 23, 132n14; see also Nussbaum 209n). Dover attempts a more systematic analysis that compares the frequency of vocabulary and constructions found in the so-called Erotikos to both Lysias' Against Eratosthenes (indisputably by Lysias) and Socrates' first speech in the Phaedrus. He finds a strong correlation between the Erotikos and Against Eratosthenes in terms of the use of axios, and the related verb axioun, in addition to the transitions that Burger and Shorey take to be evidence of parody. Dover concludes that although the Erotikos closely resembles Lysias' forensic style, this alone is insufficient to demonstrate its authenticity or parody (Dover 1968 70-1).
} 
claim that Lysias begins with the end (232e, 234b-c, 264a-b). How can the professed non-lover give his speech without admitting to being in love? ${ }^{7}$ How can he account for his own interest in sexual favours? In order to avoid this problem, Lysias lays out his thesis as a recollection so that the non-lover's intentions need not be explicitly put into words.

The main couplets of the speech, although not given in any immediately discernible order, may briefly be summarized. Since the desire (epithumia) of lovers is an illness and mania, they harm themselves and then repent when they come to possess moderation or a sound mind (sōphrosunē $)(231 \mathrm{a}, \mathrm{d}-\mathrm{e})$. They are fickle and disloyal (231b). There are but few lovers of a beloved, and so there is only a small chance of finding a lover worthy of friendship (231d). Lovers are more likely (eikos) to boast of their success in love, since they are honour-lovers (231e-232a). Moreover, since many lovers desire the body before they come to know their beloveds' interests (oikeiai), a beloved will suffer more in a quarrel with a lover because he has given up what is most valued (232b-e). Lovers make their beloveds worse, for they are so consumed by desire that they will praise words and actions even if they are not good (233a-b). As a consequence, lovers actively impede their beloveds, preventing them from associating with others lest they are tempted away by someone wealthier or more educated (232c). The non-lover, in contrast, acts willingly and according to his power, not by the necessity (anangkē) of desire, and so is able to look to his own interests (oikeia) (231a). He is the mirror opposite of the lover: he does not cause strife, chooses what is best over reputation, does not embarrass the boy, is not jealous and wants his partner to be loved by

\footnotetext{
${ }^{7}$ See Benardete 116; Burger 24-5; and Griswold 1986 46. It is important to bear in mind that "in love" here does not, in its basic meaning, carry any connotation of romantic love, but strictly means being in a state of erotic desire.
} 
many, does not want physical relations until they are friends, and provides a long-term relationship.

Despite the eccentric organization of these points, the general strategy of Lysias' speech is clear: one's interests can only be achieved through sound-mindedness rather than the mania of erōs, which is the compulsion that short-lived desire exerts over the mind (233b). The force of the argument relies on this characterization of erōs as necessarily being at odds with the determination of interest. This effectively sets commerce above love, and gives the whole speech the tone of a coolly calculated commercial transaction.

Lysias uses the word "interest" (oikeios, from oikos, "household") to bring all goods under the auspices of household management and commerce. The goods which Lysias includes are things of common approbation, such as the attainment and duration of friendship, pleasure, "the best," "some good," virtue, and especially what is "worthy" or "valuable" (axios). He leaves their specific meaning indeterminate (e.g. 232a-d). ${ }^{8}$ More concrete are the appeals to stable household relations as well as quantities of association, property, and education (232c). The non-lover alone is said to effectively provide these particular benefits, while those that are left indeterminate are construed to be beneficial simply because the sōphrosune of the non-lover allows him to provide whatever may please the listener (231b). This ambiguity concerning the meaning of interest is not unintentional, as is also the case with other crucial terms. For example, "association" (sunousia) also means sexual intercourse (from the literal "being-with"). This would be otherwise immaterial had Lysias not provided for the possibility of physical pleasure between so-called non-lovers, as "memorials of things to come" in their friendship (232e-

\footnotetext{
${ }^{8}$ Yunis 2011 99n231a4-6.
} 
233a). The word play and innuendo is in part due to the need to account for the nonlover's attraction to and enjoyment of the listener, since epithumia has been depreciated as a mad bodily lust; Lysias must substitute terms of advantage, interest, benefit, and favours or services to conceal the madness behind his moderation. The economic overtones of the speech accordingly restrict the meaning of axios to its material connotation of balancing items on a scale.

The ability to calculate one's self-interest takes on special importance in the loveless economics of the speech. The lover is particularly poor at this because of the inconstancy produced by his madness, which has the additional consequence that he is susceptible to breaking oaths (231a, 231c). Normal economic relations can be preserved only through the sound-mindedness of the non-lover; only agreements and oaths that are made willingly upon a clear assessment of interest will be inviolable. Lysias appeals to the common sense proposition that economic self-interest entails some interest in stable relations within the community and adherence to its ways or customs. He left the meaning of interest indeterminate in part because the specific determination of what is worthy or good should be the business of willing agreement between free citizens. This results in a semblance of universality where the most common of interests are sanctioned. Lysias' audience is the everyman of the Athens, who embodies the variety of interests and desires found amongst the people at large, the dèmos. The speech of the non-lover is a species of conventionalism.

Lysias, however, cannot maintain that there is a perfectly harmonious community of interest, which becomes clear in the tension between the private desires and freedom of the beloved, on the one hand, and the authority of custom on the other. Lysias accuses 
the lover of being an honour-lover who will likely boast of his erotic achievements. This attack on the love of honour is preceded by a condition: "if" the listener is afraid of "the custom" or law (nomos) ${ }^{9}$ that the relations proposed here are disgraceful, then he should be wary of the boastful lover (231e). Although pederasty was a common practice in Athens, sexual exploitation or purchase was odious, as testified by legal suits concerning prostitution. ${ }^{10}$ The non-lover, by reminding the listener of this public censure, shows some concern for reputation, and even induces a fear of censure for violating the custom. The non-lover does not argue that the provision of "services" is not shameful, or something that should not be censured; the non-lover follows the custom. Instead, the non-lover implies that he will be discreet. He regards the custom as a solely public, rather than private, matter. Indeed, the non-lover holds that there can be conflict between reputation and what is "best," i.e., the desires of the beloved, and so he invokes the custom not to chastise but to indulge the listener's concern for reputation (232a). On the other hand, if the listener is not predisposed to respecting the custom, the non-lover's reminder of censure will induce in him a fear that will drive him away from the lover's overt breach of custom and towards the non-lover's modesty and discretion.

\footnotetext{
${ }^{9}$ Nomos has a much broader meaning than simply "custom," for it also includes "law" and "ordinance," whether written or unwritten, as well as "melody." This variety of meanings in the English can be gathered together under a holistic view of the recurrent practices by which the community orders itself, analogous to the bringing together of musical tones.

${ }^{10}$ The nomos in question may refer to this general censure of sexual indulgence, particularly in public view, or even to a written law that forbade prostitution by men or women. See for example Aischines, The Prosecution of Timarchos, 19, 29-32, esp. 132-7, which draws a distinction between "noble" and hubristic pederasty (a similar distinction is drawn by Pausanias in Pl. Smp. 180c-e). Such a fine line between noble pederasty and prostitution indicates that Lysias' speech, contra Nehamas, does not "turn[] all accepted ideas about paederasty on their head" (Nehamas 1999 333-4). For a discussion of the trial of Timarchos as well as custom and laws concerning homosexual acts, see Dover 1978 19-38, 111-23.
} 
The non-lover's self-interest therefore is not incompatible with the custom, so long as the latter serves as an instrument for the former. ${ }^{11}$ Custom is of no intrinsic value. This same ethic is found or instilled in the beloved; the non-lover is not brash in suggesting they perform shameless acts, albeit in private, but does so because his audience is susceptible to it. ${ }^{12}$ Phaedrus's susceptibility to this speech suggests he is of the same character. ${ }^{13}$ The non-lover's irreverence towards the custom is then a reflection of the irreverence of the dēmos, who secretly prefer "what is best" to what is customary, while his intimation of discretion is a reflection of the fear of shame which the custom imparts. Although Lysias' speech attempts to be universal in its appeal, it must nonetheless remain private if its discretion is to be successful. The relationship between custom and household is one of tension so long as self-interest remains the ultimate determinant of worth.

The non-lover's own concern for reputation further complicates this situation. Soon after condemning the lover as boastful, the non-lover proceeds to express his hatred for those who might look down on the listener (232d). The non-lover contradicts his attack on the honour-lovers, and now argues that he wishes for the listener to be wellreputed amongst his fellows, an object of desire for many. It seems that reputation might serve the non-lover's interests after all. Lysias' speech has said one thing and then surreptitiously moved to say its opposite. In doing so, it is able to address two contrary desires: the desire to act as one wishes, scorning reputation, and the desire to preen oneself before others. Lysias here demonstrates a perceptiveness concerning the

\footnotetext{
"cf. Pl. R. 338e-339a, 358e-359a, 365b-d.

${ }^{12}$ Society, Ferrari says, has a "tolerance" for these contradictions (Ferrari 1987 89-90).

${ }^{13}$ Rhodes's formulation is succinct: "Lysias represents the most persuasive logos of democracy and Phaedrus its libido" (Rhodes 418).
} 
multitudinous and contradictory bundle of desires found in his audience. His frequent use of conditional clauses and qualifiers gives the impression of universality, as he does not preclude any possibilities - e.g., that a lover might actually not boast of his success. The argument as a whole is based on what is most "likely" (eikos) (231c7, e1, e4, 233a2). Lysias' speech not only finds that likelihood is sufficient for its purposes, but even advantageous, for it appeals to common experiences and opinions (273b1). Lysias is thus able to address the manifold and at times contradictory desires that might be found in his audience, chancing upon something of interest to any given listener. ${ }^{14}$

The moderation or sound-mindedness of the non-lover is also understood through this likelihood. Moderation actively suppresses any single-minded pursuit that would come at the expense of other interests, ${ }^{15}$ for a particular interest has no pre-determined worth - interests were examined only with respect to how they can be effectively satisfied without precluding others. This is a hedonistic calculus that preserves this variety of desires, and the possibility of their satisfaction, in order to address a multiform audience and the desires that may strike the beloved over time. Being ruled by such a moderation, the non-lover shares the same variety of desires, tensions, and even contradictions, as found in the demos. Should the listener be as multiform as the one appealed to, the non-lover would be correct in saying that he would most likely find something to his tastes amongst the many non-lovers.

Towards the end of the speech, however, this semblance of universality gives way so that not just any non-lover, but only the speaker himself, may be chosen by his audience. Given the commercial tone of the speech, and the pretension that the non-lover

\footnotetext{
${ }^{14}$ Grg. 481c-482a.

${ }^{15}$ Phd. 68e-69a.
} 
may satisfy any number of desires, it is not surprising that the criterion will be wealth. The speaker says that the listener must not give "favours" to those who need them, which would entail being charitable and not giving to the best. This, he continues, would be absurd for two reasons. First, it would imply that it is not worthy (axios) to spend on friends but only on "those needing to be filled up" (233d). Since a man is of finite means, a perpetual charitable relationship would be impossible. Lysias does not allow for the possibility of an unending hedonistic exchange based on insatiable desire, and so the listener who gives "favours" must conceive of their relationship economically. The second reason for the absurdity of charity is that these recipients would be unable to return the favour, and their gratitude and prayers are worthless, i.e., not fungible (233de). In his summation, the non-lover states that one should not give favours to those "only in love, but to those worthy [axios] of the business" (234a).

Despite the non-lover's clear superiority over the lover, there remains a problem: should the listener give favours to any wealthy non-lover? Lysias, by building the case for the non-lover upon the excoriation of eros and the lover, particularly on the grounds that lovers are jealous and restrictive, has not provided criteria for further choosing amongst the many wealthy non-lovers. Although he relied on likelihood in his previous arguments, this particular speaker has no desire to leave the final selection to chance, and therefore must provide a transition from the likely good found in common opinions to the precise good only he can provide.

Lysias gives two reasons why the listener should not give "favours" to all nonlovers: the favour will not be worthy (axios) of equal gratitude; and one cannot keep things secret $(234 \mathrm{c})$. The first reason reiterates that the criterion for ranking non-lovers is 
wealth. More interesting is the implication that an abundant supply of "favours" actually depreciates their value; like goods in the market, the value of the favour lies in its particularity. The non-lover thus gives his listener the friendly advice that he must maximize his market value by choosing only one partner. Despite the democratic veneer cultivated particularly by the promise of free association, the listener cannot but favour the man of wealth. ${ }^{16}$ Consequently, the second reason provided by Lysias, the need to preserve the secrecy that was imposed by fear of the custom, prevents the listener from selling himself around town. The non-lover is not jealous, but only interested in protecting his investment; an associate desired by many but possessed exclusively by him would be of the greatest value. ${ }^{17}$

The non-lover believes his audience, the demos, is susceptible to the temptations of wealth. ${ }^{18}$ The dèmos, perhaps not so secretly, desires wealth as a means to fulfilling its many other desires. The speech of the non-lover is not only a case of an oligarch feigning to be a democrat, but a case of democratic taste feigning universality. Indeed, Socrates immediately recognized this when Phaedrus told him the thesis, commenting that it would be of use to the wealthy and young to the exclusion of the poor and old, and so would not be beneficial to the dèmos as a whole $(227 \mathrm{c}-\mathrm{d})$.

Lysias therefore demonstrates keen insight into the relationship between speech and $e r o \bar{s}$, and how speech consequently carries ethical implications. His reliance on the variety of common opinions and desires produces a speech and form of moderation that is equivocal about worth or value. No single interest or desire has inherent value, and

\footnotetext{
${ }^{16}$ Rosen 1969435.

${ }^{17}$ Callias son of Hipponicus similarly preened himself by allowing others to be entertained by the famous sophists he hosted (Pl. Prt. 311 a, 314b-d).

${ }^{18}$ Rhodes rightly links this aspect of Lysias' speech to Socrates' charge that democrats tend to find and promote to offices those individuals who promise to gratify them (Rhodes $418-9 ; \mathrm{Pl}$. $R$. $565 \mathrm{~b}$-d).
} 
indeed even moderation and its logos are regarded as instruments of maximization. Pieper aptly describes Lysias' speech as "a rationalistic view of life as a 'technique" to maximize pleasure and minimize "complications."19 Without any natural and necessary ends, likelihood becomes the principal rhetorical tool. But likelihood is still a means to achieve the aims of love and desire, and it is only when the likely gives way that desire can be satisfied. The non-lover desires to eliminate likelihood and chance in order that he may be given favours before all others. This is a formal manifestation of the tension between the freedom of the non-lover and the mad compulsion of the lover. Lysias obscured this by using the language of commerce and the household to build a case based on the estimation of probable means rather than on the nature of ends; without a hierarchy of goods, prudence demands a moderation that balances competing desires. This is a democratic ethic that regards freedom as the highest of goods, but because of its toleration of disagreement with respect to many other desires, allows enormous scope for rhetoric.

Nonetheless, it seems absurd that Lysias would adopt a demotic form of rhetoric for a private speech, even if its immediate purpose was to display rhetorical skill to Epicrates and his guests. The reason for Lysias' appeal to the dèmos is found in the fact that it is written down - it is composed to be portable and easily passed to others, useful to whomever might come across it and wish to pose as a non-lover (275d9-e3). This would hardly be lost on a rhetorician whose career was based entirely on writing speeches for use by others in public settings; his present speech of the non-lover is the curious case of a public style of rhetoric applied to the most private of situations. This returns to the original problem of the thesis of the non-lover. A private approach cannot

\footnotetext{
${ }^{19}$ Pieper 37.
} 
be made without betraying an interest in the listener, which the speech itself points out would be construed to be evidence of sexual desire, therefore rendering the thesis of the speech patently absurd from the outset (232a-b). ${ }^{20} \mathrm{~A}$ less immediately obvious absurdity is tolerated instead: the very privacy that was guaranteed and insisted upon by the speaker as a crucial part of his argument is violated. This is dramatically illustrated by Phaedrus's ability to borrow the speech and now read it to Socrates.

The speech of the non-lover, despite the playful absurdity of its delivery, displays Lysias' talents as a writer of forensic rhetoric and his understanding of his Athenian audience. Even some of the rhetorical techniques discussed later in the dialogue can be found here, such as the manipulation of disputed things, speaking of "worth" and "interest" without defining them, the use of probability, the repetition of key propositions, alternately inciting and calming his audience, and saying opposite things, disguised through temporal separation. The speech, as paradoxical and at times as absurd as it is, is not the work of a fool, and an order can be found within it. ${ }^{21}$ It would also be too simple to claim that it does not contain any worthwhile moral teaching simply because of the speaker's deceit. Indeed, the repugnance experienced by the reader upon seeing the non-lover's willingness to exploit common decency and moderation, which he argues is lacking in the lover, is evidence of the power of those sensibilities. ${ }^{22} \mathrm{~A}$ reader of Plato would, for instance, be hard pressed to find any serious argument made in favour of the constant "filling up" of one's bodily desires or that friendships should not last

\footnotetext{
${ }^{20}$ Compare the prologue of Demosthenes' Erotikos, a love speech for Epicrates, which discusses the function of an erotic essay as if the author were speaking to a second listener other than Epicrates (D. 61.12).

${ }^{21}$ Pace Hackforth, who writes that "this tedious piece of rhetoric deserves little comment" (Hackforth 31).

${ }^{22}$ Hackforth 40; Nussbaum 208-9. Pieper argues that the rational technique advocated by Lysias is necessary for living (23).
} 
beyond the satisfaction of immediate or base pleasures. ${ }^{23}$ Any hints at a tyrannical sort of erōs are delicately moderated or attacked in the Phaedrus.

Lysias' speech of the non-lover concludes with a solicitation: "and if you are missing something, believing it to have been left aside, ask" (234c5). While this invitation to dialogue reveals the speaker's confidence that the relationship will continue, it also admits the possibility that the speech was incomplete. ${ }^{24}$ Nonetheless, Lysias expects to have gained the attention of someone who might wish to feign a lack of erotic attraction. Such a ruse should not be unfamiliar to those acquainted with the coy play between a beloved and a lover, the pursued and the pursuer. Indeed, Plato wrote the final sentence as a beautiful play on words: "ask," erōta, puns on erōs, and "you are missing," potheis, literally means "you are longing for," producing the ellipsis that, "if, believing it to have been left aside, you are longing for something with respect to love ...25

\section{A Bacchic Metaxy}

The dramatic action that follows the reading of Lysias' speech serves as an interlude between that speech and Socrates' revision of it. Plato uses this interlude to illustrate the principle of the metaxy, that is, the experience of reality that lies in-between the logoi. Socrates shows Phaedrus that it is erōs that grounds and guides the use of speech for the sake of action, and that he too is a lover rather than a beloved. Having been greatly impressed by Lysias' speech, Phaedrus does not want to ask questions of it

${ }^{23} \mathrm{cf}$. Grg. $493 \mathrm{~d}-495 \mathrm{~b}$.

${ }^{24}$ Pace Griswold 198645.

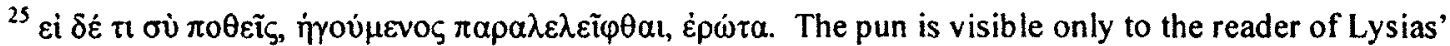
speech, not the listener, since written texts did not mark pitch accents; Aristotle describes this a species of linguistic argumentation (Sophistical Refutations 1.4). The pun plays on $\dot{\varepsilon} \rho \dot{\omega} \tau \alpha$, the second person imperative of erōtaein, "to ask," with $\check{\varepsilon} \rho \omega \tau \alpha$, the accusative of the noun erōs. The rendering of the pun takes the latter, $\check{\varepsilon} \rho \omega \tau \alpha$, as an accusative of respect and leaves the condition without a concluding apodosis. 
or examine it, despite the speech's direction to do so, but seeks Socrates' approval concerning its quality: "Does it not seem to you beyond nature both with respect to the other things and in its words?" (234c). Socrates' response bears quoting in full:

Daimonically so, comrade, so as to strike me out [of my wits] [ekplèttesthai]. And I experienced this on account of you, Phaedrus, while I was looking upon [apoblepōn] you, because you seemed to me made to shine by the speech in the midst of [metaxu] reading; since you are a leader more than me concerning such things, I followed to hear you, and so following I joined in Bacchic dance with your divine head. (234d)

The passage depicts divine inspiration. This Bacchic joining-together is something wild and rustic, verging on a maddened departure from everyday life in the city. ${ }^{26}$ The Bacchants' dance is, though, far from being an expression of sheer disorder. ${ }^{27}$

Phaedrus believes the Bacchic mood which inspires them is merely a jest by Socrates, without any serious implications (234d-e). For Phaedrus, a serious assessment of Lysias' speech would consider its use of words or its "rhetorical aspect," and whether there has ever been a speech that was so "great and numerous" in its treatment of the same subject $(234 \mathrm{e})$. His primary concern is for the form of the speech rather than its content. Socrates enjoins Phaedrus to give more attention to how he assesses speeches: "And is it necessary for the speech to be praised by me and you on these grounds, that the maker has said the necessary things... ?" $(234 \mathrm{e})$. There are things necessary to a particular speech or subject; its form cannot be separated from what is said. What form

\footnotetext{
${ }^{26}$ Following Ivan Linforth, both "join in Bacchic dance" (sunebakcheusa) and Socrates' earlier "joining in Corybantic things" (sunchorubantiōnta, 228b7) refer to instances of ritual madness or frenzy employed for the sake of therapeutic catharsis (Linforth 1946b 140). In the Laws, the Athenian Stranger speaks of Corybantism as akin to relieving a disturbed infant, "and thus artlessly they are able to charm the children, just as the remedy of the senseless Bacchants, using motion in this way together with dance and music" ( $\lg .790 \mathrm{c}-791 \mathrm{a}$ ). See Linforth 1946b 129-34, 151, 155, for further discussion of this function of the Bacchic and Corybantic dances.

${ }^{27}$ The dithyramb was a circular dance accompanied by the flute and antistrophic verse, which often depicted heroic deeds, and was always in celebration of the god Dionysus. See Pickard-Cambridge 1927 $10,28,38,47-8$. A more strict formalism accompanied later dithyramb, which was performed at public festivals (Ibid., 47; see also Pl. Lg. 700a-d).
} 
must speech about speech, i.e., the analysis of speech, take? Lysias, Socrates says, repeated himself because the things he had to say were "insufficient," which is to say that the content entailed a particular form. ${ }^{28}$ Phaedrus was amazed with Lysias' speech because he did not notice how its apparently disordered form was a necessary consequence of its appeal to contradictory desires. Socrates' own assessment is that Lysias was "displaying" (epideiknusthai) his ability to say the same thing in two different ways (235a). The speechmaker does not simply speak frankly, but manipulates words and their organization to make one thing appear as another, love as non-love.

Phaedrus rebuts that Lysias in fact did say all that he should, and did not leave out anything that was "to be expressed worthily [axios]" (235b). Phaedrus has adopted the word axios from Lysias' speech, yet he does not see how the speech manipulated the very terms by which he assesses it. Having separated form and content, or rather asserted the pre-eminence of form, Phaedrus can see neither the contradiction between the non-lover's words and deeds nor how his own attraction to the form of the speech is a reflection of his own desires.

Socrates' disagreement with this excessive praise of Lysias is deliberately phrased to show that he no longer follows Phaedrus's ecstatic lead: their previous agreement is now characterized as a going-together, sungchörein, literally meaning "to join in chorus or motion." Phaedrus's attempt to pass off Lysias' speech as a complete explication of the subject of love reminds Socrates of the speeches and writings of "ancient men and women," and that he must not let himself be refuted by them (235b, cf. 275b-d). Socrates must moderate their passion so that Phaedrus's "divine head" does not lead him into forgetfulness and wilful ignorance about love. When Phaedrus asks who these ancient

\footnotetext{
${ }^{28}$ De Vries 73n235a2-3.
} 
writers are, it is not because he is ignorant of ancient literature, but because he is incredulous that the ancients could compare with the foremost of modern writers. Socrates is not sure who he is thinking of, but mentions Sappho and Anacreon, who certainly did not cultivate the urbane trappings of "non-love," but instead celebrated as a blessing the madness bestowed by erōs. ${ }^{29}$ Although he claims to have forgotten the exact source on account of "sluggishness," this vague memory has filled his breast and inspired him to boast that he can speak differently and no worse than Lysias (235c). Socrates has been "filled up through the ears by the streams of others, like an empty vessel," just like the "daimonic" Phaedrus had been filled up and "made to shine" by Lysias" speech $(234 \mathrm{~d}, 235 \mathrm{c}-\mathrm{d}) .{ }^{30}$ Both behaved, in Lysias' words, as if they were under the influence of epithumia, "needing to be filled up" (233d). Their respective inspirations differ, though, in that Socrates knows he is being filled because he knows that he is naturally empty, i.e., ignorant of what truly inspires him. Phaedrus, however, only sees the speech, and does not recognize how it has gratified his greatest desire (258e). Without knowledge of his ignorance and emptiness, Phaedrus readily accepted Lysias' arguments and became convinced that they had expressed everything worthy on the subject. Socrates' knowledge of his own emptiness has had a moderating effect, so that despite his inspiration he is able to restrain his desire to speak.

Phaedrus, being a lover of speeches, is intrigued by Socrates' promise of a new speech. Socrates knows that he is able to tempt Phaedrus away from Lysias through this desire for novel speeches; he has laid the bait, and Phaedrus, in order to fill himself, now turns in pursuit. Phaedrus attempts to compel Socrates over four stages of increasing

\footnotetext{
${ }^{29}$ See, e.g., Sappho 2, 31, 47 [Campbell 1982], Anacreon 4, 84 [Campbell 1988].

${ }^{30}$ Pl. Ion $533 \mathrm{c}-534 \mathrm{~b}$.
} 
intensity, which Socrates playfully encourages in order to reveal the extent of Phaedrus's passion. In the first stage, Phaedrus promises that he will build a golden memorial of himself and Socrates at Delphi, "like the nine archons," in exchange for Socrates saying better and "no fewer things" than Lysias (235d). This is a curious bribe, since the allusion to the archons refers to the penalty they were sworn to pay should they violate Solon's written laws. ${ }^{31}$ Phaedrus is offering to pay for the penalty he will incur; he wishes for Socrates to violate the law for his sake. Just as Lysias predicted of lovers, Phaedrus, once he is outside the city and its moderating influence, thinks nothing of transgressing customs or laws for the sake of his desire - which is the same naïve irreverence that he shows to Eleusis and for which he will soon be exiled. Fortunately, in the present case, the "law" alluded to can only be what has been laid down by Lysias" written speech, which has hitherto persuaded Phaedrus (cf. 254c5-d1). ${ }^{32}$

Socrates refuses Phaedrus's offer by making clear that he cannot say entirely different things on the subject matter than Lysias, for not even the most incompetent writer could completely miss the mark (hamartanein). In particular, Lysias' thesis depends on the argument that good sense must be praised and lack of it admonished (236a). There are therefore necessary connections between what is said in speech and what actually exists and is already known (e.g., madness), without which a speech would hardly be sensible let alone persuasive. This connection seems to be made through erōs, either of the speaker or the audience, if one really desires to hear about the subject at

\footnotetext{
${ }^{31}$ Arist. Athenian Constitution 7.1, 55.5.

${ }^{32}$ The substance of the law which Phaedrus alludes to is unclear, since the only inscription that has been mentioned was the Delphic command (229e). This would suggest that Phaedrus violated the command to "know thyself" (Sallis 120-1). While Phaedrus is certainly guilty of failing to know his own ignorance, having him allude to the Delphic command would paradoxically suggest that he is aware that he is violating the command to know himself. This seems too clumsy an interjection by Plato.
} 
hand. Socrates is therefore compelling Phaedrus to maintain his focus on the substance of Lysias' speech rather than just flitter to another attractively formed speech. For the sake of hearing Socrates' speech, Phaedrus relents and grants to Socrates the use of the same argument that erōs is a form of madness.

In the second stage of Phaedrus's compulsion, he promises to erect a statue of Socrates at Olympia, next to the statue of Zeus that was dedicated by the tyrannical Cypselids. ${ }^{33}$ Rather than solid gold, this statue will be of "hammered metal" around a wooden core. ${ }^{34}$ Socrates again dithers by claiming that he cannot be expected to "truly say something different [and] more many-coloured to set beside [Lysias'] wisdom" (236b). The insinuation is twofold. First, that Lysias' "wisdom" is represented by the Cypselidean statue - it is an empty show piece that distracts its viewers from their enslavement. ${ }^{35}$ Second, this "many-coloured" (poikilos) "wisdom" is disorderly yet nonetheless attractive in appearance and so appealing to the dèmos and Phaedrus. Indeed, in the Republic, Socrates notes that the democratic man is susceptible to those "able to furnish pleasures of all kinds both many-coloured [poikilai] and holding in all kinds of ways." ${ }^{36}$ Phaedrus's honoring of the Cypselids indicates that he is more

\footnotetext{
${ }^{33}$ On the Cypselids' statue being an icon of Zeus, see Strabo, Geography 8.3.30. Epicrates' home, where Lysias read his speech, was also said to be near "the Olympian," i.e., the temple of Zeus (227a). Both of Phaedrus's references to sacred ground and institutions include a transgressor of the law. While Phaedrus gives voice to the institutional breakdown in the relationship between the human and the divine, he also made the first direct reference to Zeus, referring to him as the god of friendship (234e). The desire to plead in Zeus's name, despite the corruption of the god's temple, suggests that the impulses that gave rise to the sacred institutions remain, and that these impulses may indeed provide the resources for the re-founding if not renewal of those institutions. See Voegelin's discussion of the changing conception of Zeus from Homer and Hesiod through the sophists (Voegelin 2.200-4, 380).

${ }^{34}$ Morgan 1994 384-5.

${ }^{35}$ Aristotle later wrote that tyrants are wont to build monuments, such as those of the Cypselids, in order to impoverish their subjects and deprive them of the leisure needed to conspire (Arist. Politics [Pol.] 1313b19-26).

${ }^{36} R$. 559d-e. Note that Socrates also warns that "the man who is mixed is pleasing," and that the judgment of the many is that what is many-colored (poikilos) is "most beautiful" (Ibid., 397c, 557c).
} 
interested in what is manifest and delights him than the truth of the matter, even when it discloses that he has been enslaved. ${ }^{37}$

Phaedrus gives up on bribery and, in the third stage, resorts to force. He now admits that he too acts under compulsion, when he tells Socrates to speak "lest we are forced to do the vulgar business of the comedies, exchanging abuse with each other" (236c). To demonstrate this, he mimics the jibe that Socrates earlier used in order to force him reveal Lysias' speech. Socrates said that if he had forgotten Phaedrus, he would have forgotten himself, so he knows that Phaedrus put on a "pose" of reluctance in order to tempt him - and that Phaedrus would use force to make him listen if necessary $(228 \mathrm{a}-\mathrm{c})$. Phaedrus mirrors the entire scene, but in both cases it is he, not Socrates, who resorts to force: "We are alone in a deserted place, and I am stronger and younger, and from all this you must grasp what I say to you, and you must in no way prefer to speak on account of force rather than voluntarily" (236c-d; cf. 228c, e). Phaedrus is an enthusiastic mime, but it is doubtful whether he understood the import of Socrates' allusion to self-knowledge and the recognition of one's own ignorance. He mistakenly believes that Socrates really does want to speak for the sake of pleasing him, and therefore by mistaking Socrates he "forgets himself" - namely, he forgets that he loves speeches that seem beautiful to him. Phaedrus failed to reflect on why the axios, depreciation of erōs, and apparent moderation found in Lysias' speech held such great appeal for him, but he is able to recognize that Socrates' pose of reluctance is akin to his own pose, the pose of the coy beloved. This reversal of roles indicates to Phaedrus that he too is a lover, and thus moved by erōs and the very mania that the non-lover condemns.

\footnotetext{
${ }^{37}$ Ibid., 565c-d.
} 
The fourth and final stage of compulsion is intriguing, as Phaedrus threatens to stop giving speeches in Socrates' presence. Phaedrus's ultimate threat is not violence, but that he will withdraw what he later describes as the painless pleasure of speech (258e). To emphasize the gravity of this, the irreverent Phaedrus swears an oath, not to any Olympian god, but to the plane tree that they sit under and that inspires their conversation. This bond, between the plane-tree and their conversation, is the only one that Phaedrus is unwilling to transgress, since it serves to satisfy his greatest desire. Socrates too is "sick [with passion] for speeches" and is unwilling to allow the end of the conversation (228b). Socrates recognizes that Phaedrus has gambled his most dear possession, and so relents and proceeds with his speech.

Reviewing the action of the interlude, it appears that Socrates has goaded Phaedrus into revealing the extent of his passion through the transgressions he is willing to entertain. Phaedrus first transgresses civic and sacred laws, then the well-being of the people at large, then Socrates' physical well-being, and lastly their own conversation. When he is met with resistance, Phaedrus becomes more radical and less political, and so reveals his own hierarchy of valuation. The law is the first to be sacrificed, while his beloved discourse is last; only in the end is he willing to make some self-sacrifice. Phaedrus acts in the same fashion as Lysias' mad lover: he thinks his labours - the statues - will be sufficient payment for his transgression; he has no fear of the custom or law; he is indiscriminate in his love of speeches and fickle; and he is willing to do what is prohibited and will cause enmity (cf. 231a-e). On the other hand, Phaedrus's flagrancy recalls at least two strategies of the non-lover: Phaedrus promises to dedicate statues in exchange for speeches, while the non-lover promised that sexual relations would be 
"memorials of things to come"; and both Phaedrus and the non-lover promised wealth and reputation (233a, d-e). Phaedrus's actions betray his self-conception as a beloved. The need to gratify his passion in deed shows the erōs that lies behind the logos; Phaedrus is no non-lover.

In a final act of defiance to Phaedrus's compulsion, Socrates casts his cloak over his head "in shame" from looking at his friend (237a). Just as Lysias did, he puns on "I will speak" with "I love," saying that he "will speak [erō] while being concealed," or "I love while being concealed" (237a4). ${ }^{38}$ Although this deed mirrors the hidden erōs of the non-lover, Socrates' shame points beyond that concealed love. By veiling himself, Socrates separates himself from and ceases to see his present source of inspiration - the "divine head" of Phaedrus - because he is ashamed before some unknown third term beyond the two of them, the lover and his beloved. Socrates thus mimics the purification that occurs in the Lesser Mysteries of Eleusis, presumably performed to acknowledge the initiate's shamefulness and corruption, and the darkness from which he will be reborn. ${ }^{39}$ Only once Socrates has clarified Lysias' thesis of "non-love," and its implicit understanding of erōs and logos, will he be able to show Phaedrus the reasons for its shamefulness.

\section{Socrates' Inspired Concealment of Love}

The thesis of the non-lover requires a much clearer exposition because the confusion found in Lysias' speech has rendered Phaedrus oblivious to the relation

\footnotetext{
${ }^{38} E r o \bar{c}$ can mean the first person singular either of the future tense of erein, "to speak," or present tense of eraein, "to love." See note 22 on Lysias' pun.

${ }^{39}$ The Lovatelli urn depicts Hercules' initiation, in which at one stage his face is veiled while being cleansed with water (Kerényi 55-6). Also see Ar. Nu. 250-74.
} 
between erōs and logos. Socrates' speech sharpens that thesis to show exactly what it understands by erōs and how the non-lover can be consistently defended. This clarity is in no small part achieved through the form of the speech, which separates love from nonlove. The speech as a whole has five parts: a proem dedicated to the Muses; a prologue that reveals the speaker to be a concealed lover; the speech of the concealed lover proper; Socrates' interruption of the concealed lover to address Phaedrus; and Socrates' refusal to praise the non-lover. The speech of the concealed lover proper is divided into three parts: an argument outlining the principles of deliberation; a definition of erōs; and an account of the ways by which erōs harms a beloved boy. The speech of the concealed lover proper is therefore surrounded and interrupted by the inspiration Lysias attributed to erōs, which has the effect of both purifying the speech of its irrational elements in a way Lysias never did, but also the effect of betraying that coolly rational appearance.

Socrates begins with a proem that summons the Muses, as if his speech were an ancient epic poem. The proem is unusual: rather than declare the nature of the Muses as did Hesiod, he inquires into their name. ${ }^{40}$ Are they named Mousai on account of "the form [eidos] of song" which they produce, or on account of their descent from "the musical race of Ligurians" (237a)? Here, Socrates opposes Phaedrus's opinion, that a sufficient witness to the truth of a speech is its origin, and instead suggests that it is form (cf. 229c4-5, 235c1, 275b5-c2). Socrates also puns on liguros, meaning "clear," implying that Phaedrus's lack of serious concern for the form of speeches makes him susceptible to their seeming clarity - the Sirens who lured sailors to their death with their

\footnotetext{
${ }^{40}$ Hes. Th. 64.
} 
song were also a race of "clear" singers (cf. 259a-b). ${ }^{41}$ Rather than simply assert the authority of the Muses as sufficient explanation for his rhetorical power, Socrates uses his proem to question how poets, as well as prose speakers, can account for their own craft and insight. ${ }^{42}$ Indeed, he says that the speech that follows is a "myth" (237a9). Socrates thus wishes to formulate the clarity of speech, and the possibility of purely rational speech, as a problem from the very outset.

In the prologue, Socrates narrates a dramatic context for the speech, that the speaker is himself one of many lovers of a "beautiful boy" who has devised a clever thesis to win the boy over (237a). Socrates thus reveals Lysias' non-lover for what he is, and that the aim of his speech was to win the admiration of the "beautiful boy" Phaedrus. The prologue also undermines the coming speech by revealing the non-lover to be a concealed lover. This raises a number of questions with regard to the truth of the speech: is the speaker in fact immoderate? What is the status of the moderation he praises? Is a non-lover impossible? How does the speaker understand himself and his hidden erōs? Is a completely rational form of speech possible?

The speech of the concealed lover proper begins with the exposition of principles concerning deliberation. Clarity of speech and thought are paramount for deliberation and inquiry: "Concerning all things, there is one beginning for those who intend to deliberate beautifully; one must know what it is that the deliberation concerns, or it is necessary [anangkē] to miss everything" (237b-c). Ignorant deliberation may be the norm, since "the many forget that they do not know the substance [ousia] of what each

\footnotetext{
${ }^{41}$ Hom. Od. 12.44. In the Cratylus, Socrates suggests that the name Mousai is etymologically derived from the verb mösthai, "to seek," and so, properly understood, derives from the love of wisdom, philosophy (Cra. 406a). Later in the Phaedrus, Socrates will associate the mousikos, the "musical man" or "devotee of the Muses," with the philosopher (248d3).

${ }^{42}$ Rowe 1986153.
} 
thing is," but the concealed lover's use of the strict anangkē means that beautiful deliberation is not possible without knowledge (237c). Ousia is thus elevated from Lysias' usage, where it described the wealth that a lover withholds from his beloved (232c6). Unlike Lysias' non-lover, the concealed lover will not allow the arbitrary determination of terms; he demands complete clarity about whatever he speaks of, namely erōs, so that he will not confuse or contradict himself as a non-lover. One could not claim erōs is unequivocally harmful without a clear and self-consistent view of it. As will be seen, this newfound clarity requires that erōs be purged from the deliberative process altogether.

Simply assuming that one knows, the concealed lover continues, means that deliberation will only result in a failure to agree (homolegein) with oneself or others. The failure of inquiry is contradiction, something to be avoided "lest we suffer what we censure [epitimain] in others" $(237 \mathrm{c})$. Non-contradiction will therefore show the substance of the object insofar as consensus is attained. Non-contradiction is also constitutive of being honourable, for epi-timain is literally "to lay honour or value [time $]$ upon." The concealed lover thus exhorts his audience to disinter their prejudices and break the love for one's own opinions. But he does not consider, or perhaps suppresses the question, whether there can be agreement made in ignorance. Although the claim that knowledge is necessary for agreement and deliberation resembles Socrates' insistence on self-knowledge, the concealed lover allows that agreement and a self-consistent account will be a sufficient condition of knowledge. He is satisfied to replace old opinions with new ones, so long as they are agreed upon, ${ }^{43}$ i.e., replace private opinions with common opinion. Socrates will later say of the concealed lover's definition of erōs, "whether it

${ }^{43}$ cf. Smp. 209c-e; Tht. $151 \mathrm{c}$. 
was said well or badly, at least it was clear and agreed [homolegein] with itself' (265e). Contradiction is eliminated by agreement, rather than by possessing a self-consistent body of knowledge. Socrates emphasizes this by using homolegein, literally "samesaying," to signify agreement, rather than the word that he used in the interlude, sungchörein, which implied moving-together and therefore agreement in deed rather than agreement in speech $(237 \mathrm{c} 3, \mathrm{c} 5, \mathrm{~d} 1)$. The concealed lover aspires to speech, if not community, that is free of contradiction.

The final principle of good deliberation is to describe the power of the thing studied by agreeing to a definition (horos) that can be looked to (apoblepein) during the inquiry (237c-d). The word horos means "boundary" or "limit," and it is only by clearly separating the object from confounding factors that one can know it. As he will say at the conclusion of his definition of erōs, "all things are perhaps more clear when said rather than not said" $(238 \mathrm{~b})$. For the sake of this clear vision of what is deliberated on, the concealed lover wishes to bound off or limit what is erotic in order to free deliberation from the confounding and inconstant, i.e., from erōs. The form of deliberation will therefore match the content of the concealed lover's speech. Still, if the criterion for definition is agreement, the same problem stands as before: what if everyone is consistent in their error?

Since deliberation requires agreement concerning its object, the concealed lover defines erōs by resorting to common opinion, which presumes to attain the most universal agreement and therefore complete knowledge. He says that "it is clear to all" that erōs is "some desire," that is, a species of epithumia. Meanwhile, it is also the case that "we know that even non-lovers desire (epithumein) beautiful things" (237d). These 
propositions divide epithumia and the attraction to beauty into two: erōs, a mad desire, in contrast to a good and right desire. The concealed lover, unlike Lysias, is at least able to account for his attraction to the boy.

From these two types of desire, the concealed lover deduces two "forms" or "ideas" (idea) inside human beings that "rule and lead" (237d). The first is "the ingrown" or natural desire for pleasure, and the second is "acquired opinion that aims at what is best." Although the concealed lover claims that these two forms can be in accordance, their names are derived from when one or the other rules. When opinion rules by speech, it is named moderation or sound-mindedness (sōphrosune $\bar{e} .{ }^{44}$ Nothing more is said concerning the nature of moderation, which is defined only by the negation of its opposite. When desire "drags us without speech" or "irrationally" (alogōs) to pleasures and thus rules us, it is named hubris or, loosely translated, "over-reaching arrogance" (238a). This hubris, since it is "many-limbed and many-formed [polueides]," takes the name of whatever form "grows by chance" (238a). The two examples provided originate from the body: desire for food and desire for drink. As for erōs itself, the concealed lover claims it is "evident" what he should say, that erōs is directed towards beautiful things but also seeks pleasure in them through the body.

The actual content of this definition of erös and its attendant dualistic psychology is a direct consequence of the form of the speech, a deliberation based on the principles outlined above. The deliberative reliance on consensus is paralleled by the "acquired opinion that aims at what is best," while the rule of hubris that is limitless in its forms is

${ }^{44}$ cf. Tht. 210a8-b2. 
parallel to the disagreement and self-contradiction that inhibits deliberation. ${ }^{45}$ Hence, the rule of desire leads us "without speech" (or: irrationally, alogōs, 238a1, b7-8). Clarity of speech, reason, is attained by asserting the rule of opinion or moderation and extirpating erōs as the source of discordance, to the extent that it is possible to think, speak, and act independently of it. This rational speech seeks to eliminate chance in order to achieve a completely logical necessity, which the concealed lover frequently asserts throughout. Phaedrus doubts mythical stories out of the same impetus, because their chaotic and manifold nature is in discordance with the rule of common opinion and what is most likely true (229e2). Yet the presence "within us" of these two forms, hubris and opinion, is also why Lysias was able to achieve some rhetorical efficacy with contradictions and a disorderly speech. It is an interesting question whether Lysias' speech or the concealed lover's more artful speech would be more persuasive - this will be taken up later in Socrates' analysis of rhetoric as a whole (see Chapter 4). For now, it is sufficient to see that Socrates structures his speech to show how seemingly rational speech depends on the sharp distinction of an irrational element of the psyche from another, which must subject and discipline it.

The rule of opinion thus characterizes the whole of the concealed lover's speech. This is also signified in the fact that erōs is said to be a form of hubris, for hubris was a serious legal charge connoting not simply assault, but the demeaning and subordination of the victim. ${ }^{46}$ The lover's hubris is deviation from the common opinions of the city; the

\footnotetext{
${ }^{45}$ The concealed lover even subjects thinking to that consensus, since one "must think" that there are two forms in a human being that struggle for command (237d6). A type of thinking that operates outside of this moderate rule of opinion is alluded to - the "accordance" (homo-noein) of both parts of the soul - but plays no further role in this speech (237d9). This will be taken up in Socrates' palinode, when he describes the agreement of true lovers as homonoia, literally "sameness of thought" (256b1).

${ }^{46}$ MacDowell 1978 129-32.
} 
single-minded pursuit of pleasure that sets itself above all other desires and goods and threatens the diverse goods moderately balanced by the rule of opinion. ${ }^{47}$ Furthermore, since the principle of deliberation implied that only what is self-consistent can be good, and that a consistent rule of opinion is based on what is "clear to all," there is no need for the concealed lover to substantiate the nature of "the best." The only task remaining is to discredit erōs by providing particular examples of how it causes a separation from what is commonly thought to be the best. The association of erōs with the body is especially helpful towards this end, given that the ills of the body are the most self-evident (263a-b).

Immediately after defining or "bounding" erōs, Socrates interrupts himself in order to remind Phaedrus of the speech's mythic and poetic qualities. Parodying Phaedrus's earlier inspiration, Socrates asks, "does it seem to you that I have suffered a divine experience?" $(238 \mathrm{c})$. He is, "if not yet," close to speaking "in dithyrambs," the Bacchants' ritual of song and dance (238d). ${ }^{48}$ This interjection of divinity is striking, as such language has so far been absent in both speeches. The divine reappears in the middle of the speech as an extra-logical return to the metaxy. The expression of divinity through Dionysian ritual subverts Socrates' speech, for Dionysus is the god of wine, drunkenness, and generation or change. ${ }^{49}$ Implicitly, even though the speech attacking erōs appears to be very human and sober, it cannot escape this Dionysian source. The rational speech is not the moderate, unified, and clear account of erōs that it portrays itself as, but born from something more than human that takes many forms. Indeed, erōs as a form of madness and hubris threatens to overflow the boundaries set around it by the

\footnotetext{
${ }^{47}$ See Burger 140n43.

${ }^{48}$ The antistrophic character of the dithyramb parallels the duality of the two forms in the soul. See note 24 above.

${ }^{49}$ See e.g., Hes. Op. 609; Hdt. 2.123; E. Bacchae (Ba.) 535, 650, 770; Apollod. 2.29.
} 
concealed lover's definition, which Socrates sees as some kind of divinely inspired myth (see 237a9, 241e8, 243a4). This does not mean the speech is simply false, but that it partakes in something beyond what is merely "likely" and seems to be the case. The great necessity that pervades Socrates' speech is provided not by knowledge of the principles of speech, but by the mysterious inspiration of erōs.

That hubris and erōs underlie the moderation of Socrates' speech must be troubling for Phaedrus, insofar as he is a devotee of moderation. In retrospect, the hubris of this moderation was already intimated by its struggle to rule over the many desires for pleasure, just as each desire itself struggles to rule. Moderation's claim to balance those desires implies their equality in that they all tend to hubris, but by asserting its own claim to rule, which the concealed lover says it must if the substance of what it deliberates on is to be known, it supposes itself to be greater than all of them together. Moderation belies a need to hierarchically organize for the sake of good deliberation. ${ }^{50}$ But its claim to rule can only be substantiated by showing that its counterpart, the rule of the desire for pleasure, is harmful.

When Socrates resumes the guise of the concealed lover, he returns to his definition of erōs. He again invokes its clarity, saying that "what must be deliberated about has been spoken and defined, and indeed looking towards that let us say the rest, what benefit or harm is likely to come to pass for the one giving favours, both from the lover and non-lover" (238d-e; cf. 237c-d). What is harmful is already understood to be that which separates one from the rule of opinion that aims at what is best. Harm is caused in each case in the following way: the definition of erōs implies the "necessity" that a man ruled by desire for sexual pleasure, a lover, must make the beloved as pleasing

\footnotetext{
${ }^{50}$ Weaver 8-9.
} 
to him as possible; this "sick" man finds pleasing that which offers no resistance, and because of this hates what is stronger or equal; therefore, the lover will seek to make his beloved weaker than him and delight "by necessity" in that weakness, whether it is weakness of wisdom, courage (or: manliness, andreios), rhetorical skill, or shrewdness $(238 \mathrm{e}, 239 \mathrm{a} ; \mathrm{cf} .232 \mathrm{c}) .^{51}$ Socrates then illustrates this argument through a number of particular cases where a lover will cause harm, from the mind to external possessions and pleasure.

The first example of how a lover may harm his boy is with respect to the mind, which the lover prevents the boy from improving on account of his jealous fear of losing the boy. The lover prevents the boy from learning "divine philosophy" (239b). Instead, the lover wishes for the boy to remain ignorant and "look to [apoblepein] all things which concern the lover himself." Curiously, the boy will look to the lover just as Socrates looked to (apoblepein) Phaedrus in the interlude - as a source of inspiration - and just as those who deliberate well look to (apoblepein) their definition $(234 \mathrm{~d} 2,237 \mathrm{~d} 1)$. The use of the verb apoblepein here suggests that the act of definition or drawing boundaries, rather than giving clarity and precise knowledge, is akin to keeping the subject ignorant and enthralled. ${ }^{52}$ Phaedrus later will illustrates this, as he will offer a definition of rhetoric that Socrates will have to work with while attempting to persuade him that the opposite is true. Here, Socrates' use of ordinary language makes the concealed lover inadvertently betray his own passion. Perhaps a completely dispassionate use of speech, and the hiding of reality behind words, is not possible to the extent that the concealed lover hopes.

\footnotetext{
${ }^{51}$ The opposite of Phaedrus's account of erōs in the Symposium, where erōs is agonistic without jealousy, which makes the partners better (PI. Smp. 178e-179b).

${ }^{52}$ These instances are the only three uses of the verb in the entirety of the Phaedrus (234d, 237d, 239b).
} 
The second area where the boy is harmed is his body. The lover "is compelled to pursue pleasure before the good," and seeks what is physically inferior (239c). The lover gives him a "therapy" of the worst sort. Perhaps with the book-loving Phaedrus in mind, the boy will be made soft, raised in "shadowed light," unversed in exertions and labour, and dressed in "borrowed colors and ornaments," among many other things (239d). ${ }^{53}$ In short, the boy will be weakened such that "in war and other such great crises the enemy is heartened, and his friends and lovers seized by fear." ${ }^{44}$ The body is therefore not depreciated along with erōs, but its excellence is determined by the needs of the city, the most basic being self-preservation, rather than pleasure. Indeed, erōs understood as the desire for bodily pleasure cultivates neglect for the toil and self-sacrifice required for the well-being of the city.

The concealed lover says that the argument concerning the body is "clear" (dēlos), and the third area, possessions, will also be made "clear" (saphēs) (239d-e). The lover wishes his boy to be deprived of all familial relations and friends, who would be censurers (epi-timêtai) of their life of pleasure. ${ }^{55}$ These associates follow the custom concerning pederasty and are concerned with the honour of the boy. The lover will also strip the beloved boy of wife, child, or home, and it is "necessary" that the lover deprive his boy of property in order to make him more manageable. The lover effectively removes his beloved from the household. The concealed lover's censure, on the other hand, means that there is no retreat from public view, but rather the opposite: a consistent appeal to public appearance and honour, reinforced by private relations, in order to

\footnotetext{
${ }^{53}$ Dorter notes that this "resembles perfectly the appearance of Dionysus" in Euripides' Bacchae (Dorter 284-5; E. Ba. 455-60).

${ }^{54}$ This parallels the city in speech of the Republic, which pits its well-trained guardians against the weak, pale, and luxurious oligarchs of foreign cities $(R .442 \mathrm{a}-\mathrm{c})$.

${ }^{55}$ cf. PI. R. 574a-b, 576a.
} 
condemn the lover and his private $e r \overline{o s} .{ }^{56}$ The reliance on consistent common opinion entails a kind of public or political holism, deviation from which is indicative of a private madness.

The argument now moves into the realm of pleasures, which on the face of it would seem to be the most rhetorically powerful argument against the lover, whose essential devotion to pleasure will prove unpleasant to the beloved. The lover is a flatterer able to provide brief pleasures that some "daimon" has mixed with bad things (240b) ${ }^{57}$ But there is no real pleasure nor benefit to be had from the lover because his age will repel the boy. It is on this explicit appeal to the boy's desire for pleasure that the speaker's guise of moderation and "non-love" seems to falter, for it raises the question whether the concealed lover means to imply that he himself will provide pleasure, and if so, whether that is consistent with his moderation. Both lovers and non-lovers, after all, "desire what is beautiful," and the definition of hubris shows that only the rule of the desire for pleasure is contemptible, not the desire for or experience of pleasure per se (234d).$^{58}$ For the definition of the soul not to contradict itself by saying that the rule of opinion and the rule of hubris are the same, it must be the case that, for the non-lover, it is opinion which determines what is desirable and when it is desired, and not his inborn desire for pleasure. Nonetheless, given that the rule of opinion was shown to be agreedupon opinion, i.e., the consensus of the community, the non-lover will only desire what the community as a whole desires. He claims to eliminate private erōs entirely.

\footnotetext{
${ }^{56}$ Compare the elimination of private households in favor of a communal one in the Republic, which is more directly harnessed to what is honored by the city and its laws $(R .423 \mathrm{e}-424 \mathrm{a}, 457 \mathrm{~b}-\mathrm{d}, 462 \mathrm{a} \mathrm{ff}$.).

${ }^{57}$ Socrates develops the argument that rhetoric is a species of flattery in his conversation with Gorgias and Polus (Grg. 463a ff.)

${ }^{58}$ Hackforth 48.
} 
The concealed lover concludes on the issue of oaths. Since it has been shown that there is no present benefit in the lover, only the lover's promise of benefits in the future will attract the boy. The possibility of fulfilling that promise is crucial. The lover, though, will break his oath when his love ceases, as Lysias repeatedly argued (231a, 232b, e, 234a-b). This "former lover" now becomes sensible (nous) and moderate rather than "erotic and mad," and defaults "by necessity" (anangkē), fleeing from his creditor, the boy (241a-b). The boy is likewise compelled (anangkazein) to pursue, ruing that he was "ignorant with respect to everything from the beginning" - he did not have the benefit of clear deliberation and analysis of erōs. The boy now realizes "that he must not give favours to the lover and the one who is by necessity [anangkē] mindless but much rather to the non-lover and the one who has possession of his mind [nous]" (241b-c). Otherwise, he would "necessarily" (anangkaion) surrender himself to someone untrustworthy, peevish, jealous, disagreeable, harmful to his property, harmful to his body, and most of all harmful to the education of his soul (psuchē) (241c).

The necessity which runs through this passage - the logical necessity of definition and the necessity with which erōs compels those it possesses - completes the charge against the lover, who was found to be necessarily unjust. The lover desires nothing less than to be the receiver of free gifts, and in this sense he is identical to the beloved so honoured by Phaedrus. He is insatiable: "for the purpose of filling up, as wolves are fond of lambs, so do lovers feel affection for a boy" (241d). The necessity of erōs encompasses the boy as well, whose own desire compels him to pursue what is owed, as if he too were now a lover. Rupturing the bonds of erōs arouses the anger of justice, as seen in Socrates' earlier allusion to the Areopagus. The concealed lover's remedy for this 
injustice is to be moderate, to cleave to common opinion as found in the city, since it is, by reason of its negation of erōs, the only source of trustworthiness and clear deliberation. Only the concord of opinion can provide for justice and benefit. Only when the erotic individual is brought back into the moderating fold of common opinion will benefit accrue to him, his associates, and the city as a whole.

Socrates has used the clarity afforded by the concealed lover's deliberative principles and psychology to reveal the kind of erōs that Lysias' non-lover opposed. But Socrates also imputes this erōs to rhetoricians like Lysias and the concealed lover, insofar as they are unable to speak and persuade in the absence of desire. Socrates' account of the lover is therefore also a portrait of the kind of rhetoric such men would employ. This ignoble rhetoric would, like the lover, oppress the beloved in every possible way, not least in "the education of his soul," for the purposes of his own gratification (241c5). This sort of rhetoric would refuse deliberative argument, eschew clear definitions, mix its terms, and obscure any logically necessary deductions that would follow from his words. He would be the flatterer who mixes momentary pleasure with the bad things he peddles - just as Socrates argues in the Gorgias. ${ }^{59}$ A real account of the substance (ousia) of things would be anathema to this rhetoric. ${ }^{60}$ If the erōs of the concealed lover is of the kind portrayed here, his own recommendation of clear deliberation would be either a rhetorical blunder or so contrived to more effectively oppress the beloved by concealing what is truly beneficial.

With the attack on erōs complete, Socrates breaks off his speech and pleads with Phaedrus to let him stop. Phaedrus complains that Socrates has stopped halfway through

\footnotetext{
${ }^{59}$ Grg. 463a ff.

${ }^{60}$ Weaver 11.
} 
the speech - he still needs to praise the non-lover and conclude that "it is necessary to grant favours to the [non-lover] rather than that man [the lover]" (241d). Phaedrus not only wants the speech to balance itself as a complete whole, but wishes to experience the rhetorical turn, the delight of one's original position, i.e., granting favours to a lover, being turned upside down. Socrates again pleads that he not be forced to continue, telling Phaedrus that the second half of the speech would be just as one might expect, that the non-lover is the opposite of the lover and possesses all the good qualities that the other does not. Were Socrates to continue, he would be completely possessed by the nymphs that inhabit the grove they sit in, for he has already gone from uttering "dithyrambs" to "epic verse" (indeed the frequency of epideictic or expressive vocabulary and poetic phrases increased over the course of the speech, culminating in the similitude of lovers and wolves) $(241 \mathrm{e}){ }^{61}$ He refuses to praise the non-lover because he would be possessed by the inspiration that has been hidden behind the logos, which is to say that his concealed lover would become an overt lover.

The speech of the concealed lover cannot be delivered without contradicting itself, both in deed, as was the case with Lysias, and in speech. The non-lover would ostensibly be moderate, i.e., ruled by opinion rather than the desire for bodily pleasures, and so lead the boy towards philosophy, encourage him to take care of his body in order to fulfill his civic duties in war, respect his ties to family and friends without jealousy, help preserve his property, be not unpleasant company, and keep his oaths. This

\footnotetext{
${ }^{61}$ Aristotle argues that because epic poetry link a series of episodes by narration, the imputation of necessity in this connection is most desirable. This consequently allows ample opportunity for the introduction of irrationalities and the concealment of absurdities (Poetics 52a, 60a-b). Aristotle observes that Homer taught us well how to tell falsehoods (lbid., 60a 18).
} 
resembles the true lover that will be portrayed in the palinode. ${ }^{62}$ But all this would be done in exchange for "favours," i.e., sexual gratification, and if the exchange is on the basis of bodily desire, there could not be any moderate rule (see "favours" at $237 \mathrm{~b} 6$, $241 \mathrm{a} 5, \mathrm{~b} 7, \mathrm{~d} 5$ ). According to the concealed lover, these two opposite states of mind and mindlessness cannot coincide.

Despite the clear and ordered definition provided, the concealed lover's dualistic psychology is simply insufficient for the task of accounting for himself, i.e., the task of self-knowledge. For him, the lover's abrupt change into a moderate man was quite literally a change into "someone else," for there is no man who can at once be opposite to himself, moderate and hubristic, sensible and mindless $(241 \mathrm{a} 4) .{ }^{63}$ Ferrari rightly notes that the appropriate response to having such desire, while holding this understanding of erōs, is "self-hate"; the delivery of the speech would be purely deceptive and its praise for common opinion would be false, such that the professed justice of the non-lover would be nothing more than a ruse to solicit the attentions of the beloved and no more secure than the oaths of a lover. ${ }^{64}$ Yet common opinion and convention is the necessary instrument for the concealed lover's deception, as it is the authority upon which he attacks the lover. ${ }^{65}$

Nor will the speaker, so long as he remains the moderate non-lover, achieve his hidden desire. Moderation understood as simply the rule of opinion that aims at the best,

\footnotetext{
${ }^{62}$ The true lover, who founds his friendship with the beloved boy on the distinction of the boy from the true beloved, i.e., the being of beauty itself $(254 \mathrm{~b}, 255 \mathrm{~d}-\mathrm{e}, 256 \mathrm{e}-257 \mathrm{a})$, is not the ecstatic lover that abandons earthly relations (252a3-6). Pace Griswold 1986132.

${ }^{63}$ In the palinode, Socrates describes this experience as one of perplexity at the change, but ascribes it to the beloved rather than the lover (255d-e).

${ }^{64}$ Ferrari 1987 98; Brown and Coulter 420.

${ }^{65}$ Newell notes that this is the dilemma that Callicles faces in the Gorgias: he despises common opinion and its attendant moderation yet is entirely dependent on it for his own gratification (Newell 34-5; see Grg. $510 \mathrm{~d}-511 \mathrm{a}, 512 \mathrm{~d}-513 \mathrm{c})$.
} 
which suppresses the rule of any single desire, is an insufficient guardian against hubris. It cannot provide for the satisfaction of what is pursued by erōs, and can only serve to temper erotic outbursts and indulgences. It is no guarantor of trust, oaths, and thereby justice as it is defined here. As Friedländer writes, "[t]his specific mode of life is led to reveal its true nature." ${ }^{66}$ This moderation has little to recommend it, as its professor's satisfaction requires the intermittent complement of erōs as an overflowing Dionysian interruption. Such inconstancy is not moderate at all.

Moreover, if the concealed lover indeed understands his own erōs as he described it, even the principles of deliberation originate out of his "irrational" (alogos) erōs. The act of defining, the clarification of an object by delimiting it in words and naming it, is itself an act of hubris that oversteps boundaries for the satisfaction of desire. Defining is in no way a selfless or disinterested act, and neither is its product divorced from the precipitating desire. The defined object is seen not as it simply is, but irrevocably mixed to satisfy the preconceptions formed by erôs. The good deliberation of the concealed lover, depending as it does on the knowledge obtained through definition, cannot be completely realized: the object of deliberation will always elude complete clarity in the need for a decision. ${ }^{67}$ Furthermore, insofar as conversation and speaking relies on definition and naming (e.g., 249b6-c4, 265d3-266b1), it too is an act of hubris rather than moderation. There is no possibility of a purely rational and dispassionate discourse; the clear and moderate speech of the concealed lover, understood on its own terms, cannot justify itself. By extirpating erōs from logos and good sense, the concealed lover has only obviated self-understanding and with it the possibility of his complete satisfaction.

\footnotetext{
${ }^{66}$ Friedländer 3.225-6.

${ }^{67}$ Ferrari 1987 51-2.
} 
His reliance on common opinion ensures that the erōs behind his speech will always remain an irrational element that cannot lead him to clear thinking about whatever he deliberates on. He will always dwell in opinion without the possibility of touching on what truly inspires his thought and action, and therefore, lacking agreement with himself, will not attain what is truly good. Socrates' speech shows Phaedrus that rhetoric cannot be merely a matter of form where its words are arranged to any effect, but relies on the opinions and therefore desires of both the speaker and the audience.

This is not to say that nothing has been achieved with respect to clarity, for the concealed lover has shown sufficient discipline and rigor to differentiate in himself two opposing forces, unlike Lysias, and attain a clear view of a kind of $e r \bar{s} s$, if not the whole of it. Socrates goaded Phaedrus into forcing him to speak so that he might reflect back a clearer account of erōs as Phaedrus understands it - Socrates even calls it Phaedrus's speech (243e9-244a2). But the speech is also an account so formed that it might be harnessed to something less shameful (cf. 255c-d).

The possibility still remains that the concealed lover's erōs is not as he has defined it. The concealed lover included the qualification that even a non-lover can desire beautiful things, which accounts for his attraction to the boy (234d). The concealed lover and the boy can come together in the fashion of moderate men, each desiring the beautiful but never succumbing to the rule of pleasure. Such a "desire" would therefore disregard its commonly attested object, and would be almost unrecognizable as the desire (epithumia) at the heart of the concealed lover's definition of erōs. The meaning of the "favours" given would also have to change into something almost unrecognizable, into that which does not give bodily pleasure. The only way for 
the concealed lover's praise of non-love to be consistent with his actions is for him to countenance a different kind of $e r \bar{s} s$, such that the erōs which Socrates says possesses him is not the erōs portrayed by the speech. Socrates will later say that the urbane speeches divided erōs in two, taking the "left-handed" erōs in order to censure it (266a). Speech that is truly coherent and capable of accounting for itself and the speaker's desire for gratification must somehow also encapsulate the right-handed erōs.

Despite its deficiencies and ultimate self-contradiction, the speech of the concealed lover marks a clear improvement over Lysias' speech in at least two ways. The first is the clarity of arrangement and development of arguments, as discussed above. Lysias' series of antitheses obscured his argument against lovers and ultimately the distinction between lover and non-lover. From Socrates' clarity of form follows the second improvement, that the speech of the concealed lover makes a clear distinction between the goodness of moderation and the harmfulness of erōs. It is consistently able to maintain this distinction throughout, although this depends on Socrates ending the speech before the portrayal of the non-lover and the speaker's proposition to the boy. Nevertheless, instead of playing on the various tensions found in the city, as Lysias did, the concealed lover makes a more obvious claim to universality by firmly subordinating associations, bodily excellence and courage, honour, pleasure, justice, and generally all goods, to the rule of opinion.

Socrates shows Phaedrus that a consistent defence of non-love would necessitate adherence to a completely self-consistent common opinion, which culminates in a moderate conventionalism. Socrates plays on Phaedrus's valetudinarianism in order to lead him away from his selfish love and envision the possibility of a "non-love" that 
would benefit others and respect the customs of the city. Adherence to this unified common opinion demands that the speaker separate himself from his private bodily attachments. This need for a cause of action that is differentiated from the body is why the first use of the word "soul" in the Phaedrus occurs here (241c5). There is accordingly "nothing more valuable, either to human beings or to gods" than the education of the soul (242c). This complete harmony of common opinion and respect for custom, won by the attack on the private realm and the disturbances of erōs, as well as the purification of the form of speech and vocabulary, bears an interesting resemblance to the overt program of the just and beautiful city in the Republic. ${ }^{68}$ Socrates will later confirm that the moral teaching and rhetoric of the concealed lover need not be cast aside, for it abused that part of erōs that it found "with justice" (266a). Whatever the deficiencies of this speech, it is an ascent from the thinly-veiled hedonistic calculus found in Lysias' speech, which was, in turn, certainly more moderate than the excesses of the erōs that it attacks.

When the speech of the concealed lover proper is supplemented with Socrates' extra-logical contrivances, the dramatic irony of the whole speech implies that there exists a higher form of erōs that guides Socrates himself. His earlier reference to Sappho and Anacreon - who saw erōs as madness but nonetheless embraced it as a blessing indicates that he already had in mind what will be discussed in his next speech. The concealed lover's artfulness and logical discipline is a crucial step towards the

\footnotetext{
${ }^{68}$ A similar dialectical unfolding of the soul is found in the Republic, where Socrates first differentiates spiritedness (thumos) from desire, and then the intellect from spirit on the issue of right opinion, since the duality of spirit-desire proves unable to maintain unity in soul and city $(R .375 \mathrm{a}-\mathrm{e}, 412 \mathrm{e}-414 \mathrm{~b}, 439 \mathrm{c} f \mathrm{f}$.). On the purification of speech, see Socrates' argument that poets must only use "simple" rather than imitative narrative (Ibid., 392c ff.). Also see notes 54-56, above.
} 
recognition and articulation of the erōs that inspires the logos and guides it to what is most desirable.

\section{The Urbane Speeches}

The urbane speeches revealed Phaedrus's attachment to the opinions of the city, despite his selfish indifference to its institutions and customs. The speeches showed that his hopes for rhetoric as a dispassionate instrument could not be achieved, for the logos addresses the desires of the speaker and the audience, which cannot be satisfied with what only seems to be good. Rhetoric is nonetheless capable of persuading its audience of what is false because of disagreement or contradiction within the audience, whether another person or oneself. Lysias' speech took advantage of these contradictory opinions, including the tension between the desires of the private individual and what is customary, to affect a comprehensiveness (it was "multicoloured" and its propositions about erōs were "likely") that was attractive to Phaedrus. Socrates' speech of the concealed lover, however, sought to eliminate contradiction in order to provide a more consistent account of erōs and moderation that would be able to satisfy the aims of deliberation with a logical necessity not found in Lysias' speech. The ambitions of this rationalized and dispassionate rhetoric were, however, confounded by Socrates' extralogical contrivances, such as his shame, proem, prologue, and Bacchic interruption, which revealed the underlying problem that erös lies behind the logos.

Socrates' exposition of the erōs of speech and rhetoric was concomitant with the repudiation of the ethic of Phaedrus and the rhetoricians who style themselves as nonlovers. As the moderate beloved, the thesis of non-love was particularly attractive to 
Phaedrus, for it promised the effective and rational acquisition of whatever desires he might have. But the moderation of non-love is premised on ruling every desire as something equally destabilizing to the attainment of other desires, even though this rule itself implies the presence of a higher erōs which rules the other desires. As a consequence, this moderation precludes the possibility, and therefore the study, of a hierarchy of desires, let alone the higher erōs that moves it. ${ }^{69}$ Only an openness to that erōs, produced through the refutation of the moderation of the non-lover, would allow Phaedrus to engage in self-inquiry and find what is truly desirable (252e6-253a4). This was the meaning of the Bacchic interlude or metaxy between the speeches. Socrates' redirection of Phaedrus to the metaxy is an exhortation to see the tension that is formed within the soul between the desires hidden by the logos and the logos itself: Phaedrus seeks to order and delimit things with the clarity afforded by speech, yet does so for the sake of a desire that eludes logical apprehension and boundaries. Only by recognizing this tension will the rhetorician see the possibility of an erōs that transcends the oppressive and destructive erōs rightly attacked by Lysias, and the urgency of understanding it.

Socrates does not immediately begin his palinode, which praises erōs, but literally turns to go back towards Athens. In doing so, he mimics the lover who refuses to pay his debt and makes Athens an icon of the sensibility and moderation found in common opinion. In order to seek recompense and satisfaction, Phaedrus is once again compelled to pursue Socrates like a lover and thereby turn his back on the city. The city and

\footnotetext{
${ }^{69}$ Phaedrus's own experience as a beloved should show him that, because the lover lacks something that the beloved possesses, what is loved is higher than love (see PI. Smp. 202c-d). Pieper describes the tension between an open-ended erōs and dispassionate moderation portrayed in the speeches as "an everlasting problem" between transformative upheavals and the need for rational organization (Pieper 23).
} 
political life must be left behind so that they may obtain a view of what it is that lies outside of opinion that erōs so greatly desires. 


\title{
PALINODE
}

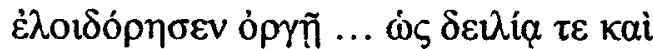

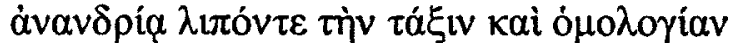 \\ He abused them in anger ... that they were deserting \\ their post and agreement in fearfulness and unmanliness
}

Socrates has turned his back on the urbane speeches and now leads Phaedrus into a grand defense of the mania of erōs. This third and final monologue of the Phaedrus assumes the form of the show-speech, the epideiktikos logos, which rhetoricians would deliver on momentous occasions or simply as a piece of entertainment. ${ }^{1}$ As demanded by the situation, epideixis eschews the restrictive vocabulary and techniques regarded as more appropriate for forensic and deliberative speech. Indeed, Socrates will make use of fantastic mythical imagery, poetical phrasings and extravagant use of words (e.g., "the superheavenly place"), heavy-handed plays on words, and even a narrative structure. It is tempting to say that Socrates attempts to establish the goodness of erōs simply by the attractiveness of the form of the speech itself. This resplendent, even ecstatic, form is intended to be in sharp contrast to the prosaic and moderate quality of the previous speeches, and has often attracted attention from readers in complete isolation from the remainder of the Phaedrus; it is without a doubt the dialogue's most memorable moment. But this form makes the speech very difficult to interpret, for Socrates speaks without arguments, as if he were again a mouthpiece for the Muses. This is not to say that there is no sense to the speech, for it is incredibly self-consistent in its use of imagery and terminology, and follows a logical structure from beginning to end. Moreover, many hypotheses that are, in other dialogues, argued by means of Socratic refutation can be

\footnotetext{
${ }^{1}$ Arist. Rh. 1358b-9a.
} 
found in the palinode in mythical form. Indeed, Plato seems to have given, in one of the greatest myths of his corpus, a holistic account of the some of the most fundamental principles of his thought. Many commentators are inclined to believe with Friedländer that Socrates has "unfolded the myth out of doctrine."2 This has further led some of them to attempt to find that doctrine by interpolating arguments external to the dialogue, with varying success, given the differences in their formulation and dramatic context across dialogues. ${ }^{3}$

Demystification of this sort is not what Socrates criticized in the prologue as the overly-clever debunking of fantastic myths, such as winged horses, on the basis of what is likely (229c-e). But this method does obscure, if not refuse, from the outset, the interpretive need to understand the myth on its own terms and in the context from which it arises. In short, there will be no understanding of the speech as it is given. Socrates fashions the palinode in the first place for the sake of Phaedrus. Its apparent excesses are not, then, failures of logical argumentation attributable to its mythical form, but parts necessary to the creation of a cohesive speech that is appropriate to this task, and can, in a very compact form, develop the meaning of terms and introduce principles that will be required for the later dialogue on rhetoric.

In this chapter, it will be argued that Socrates uses his palinode to show Phaedrus how erōs is at the heart of the psychology upon which persuasion and the use of speech rest. The narrow understanding of the urbane speeches, that erōs is a bodily desire for pleasure, is shown to be derivative of a more fundamental experience of the soul's tension with reality, i.e., the experience of the metaxy that Plato depicted as the grove

\footnotetext{
${ }^{2}$ Friedländer 1.192. See also White 1993 1-9.

${ }^{3}$ Most conspicuous are the relevant chapters in Nicholson as well as Hackforth's translation and commentary (e.g., 71-7).
} 
under the plane-tree. The myth of the palinode illustrates how erōs implies the soul's participation in eternal beings, which are perceived through speech and reasoning. While the pleasurable experience of beauty leads many to seek continuous gratification, a few recognize that what is truly desired does not lie in the finite and fleeting experiences of pleasure, but in a return to the eternal beings whose transcendence can only be perceived by the reasoning mind. The greatest good fortune that can be bestowed by erōs is the philosophic friendship that recognizes that the true object of mutual desire lies in opening the soul to the true nature of reality. The resplendent beauty of the palinode is thus Socrates' own attempt to stir Phaedrus out of his stifling moderation and awaken him to the true powers of speech.

\section{The Shame of Socrates}

While the concealed lover of Socrates' first speech cast shame upon pleasure seekers and the unmanliness of love, Socrates himself cast shame upon the whole speech that Phaedrus compelled from him. A number of forces seem to conspire to restrain Socrates and prevent him from returning to an Athens that would surely forgive his behavior as a moment of madness. Phaedrus first appeals to Socrates' sense of bodily comfort, telling him that because the sun is at its apex everything comes to a halt - it is far too hot to venture outside the pleasant shade cast by the plane tree. Phaedrus further suggests they discuss what has been said, which seems so striking to Socrates that he deems his young friend "divine" and "artlessly [atechnōs] wondrous with respect to speeches," unparalleled in his lifetime except by Simmias the Theban (242a). Socrates here returns to Phaedrus the epithet of "artless" that was given to him when he was 
inspired by the sight of the plane tree; Phaedrus's love of speeches is akin to Socrates' guileless inspiration rather than the supposed artfulness of professional rhetoricians like Lysias (230c7). Like Simmias, the man who instigates Socrates' final conversation in the Phaedo, Phaedrus would converse endlessly, ceasing only when the body falters. The love of conversation and bodily moderation are only secondary concerns, however, for Socrates claims that his "customary sign," his "daimonion," has restrained him, which he interprets as the demand that he atone for his disparagement of Eros (242b-c). Socrates' shame is entirely internal in its origin - Phaedrus was of course no inhibiting force - and depends on some form of fidelity to the divine.

As Socrates says, he is "a seer" (mantis), who has been shown the path of purification by the "spot itself," that is to say, by the grove under the tree or the metaxy (242c). Unlike the great seers who deliver prophecies, Socrates is merely "sufficient for himself" and able to learn his offense. But how could he know what is sufficient for himself when he does not yet know himself? Perhaps he has begun to understand himself by learning what offenses, mistakes, he has committed, as he says, but how could he know they are mistakes? Errors made by the soul do not reveal themselves in the same manner as errors made by the body do, like the impediments posed by a glutton's fatness or pain by a drunk's headache (238a-b, 263a). The soul must somehow be prophetic, Socrates tells Phaedrus; the soul seems to have some premonition of what is good or bad and this seems to come through shame.

Socrates' shame does not, however, originate from Phaedrus - the sort of shame that one might experience before custom or the opinions of others, as Lysias employed. Rather, Socrates' shame is internal and attached to something divine. Socrates' speech 
indicated that these two forms of shame do not always coincide, such that what is truly shameful is not necessarily the object of public shame; the many do not know what is truly shameful. Socrates illustrates this problem with a quotation of the erotic poet Ibycus: "Lest by committing some offense against the gods I should receive in exchange honor from human beings" (242c-d). ${ }^{4}$ The error originates from human ignorance of what is demanded by the gods. Ibycus implies that the moment of glory is the very moment one should be ashamed; what is dear to the gods and dear to the community of men are not only different but may fall into tragic opposition.

Socrates' mention of old Ibycus also serves to foreshadow the power of erōs that will be described in his coming speech. Phaedrus, being fond of literature, would recall that the poet sang of Eros as an uprooting storm and violent compulsion, as did Lysias and Socrates, but also sang of its life-giving force. ${ }^{5}$ He also sang of the "everlasting glory" of song - glory which would, it seems, place the poet in discordance with the gods. How could Ibycus' reveling in the power of erōs allow him to escape divine shame $?^{6}$ Should one not rather sing of moderation to avoid divine wrath? But the urbane speeches that did so are roundly criticized by Socrates.

His first speech, Socrates tells Phaedrus, was "stupid" (euetthe), "impious," and thus "terrible" or "clever" (deinos) (242d). Socrates does not specify whether stupidity or impiety is more responsible for the speech being terrible, and perhaps they are not entirely distinct. The equation of stupidity and cleverness is strikingly paradoxical, and

\footnotetext{
${ }^{4}$ Ibycus (Ibyc.), fr. 278 [Campbell 1991]. Socrates' quotation is corroborated by the other sources, which do not supply any further context.

${ }_{6}^{5}$ lbyc. fr. 282, 286, 287.

${ }^{6}$ Socrates' quotation of Ibycus may allude to Parmenides (Prm.) 137a, when Parmenides also quotes Ibycus (White 1993 3-6). Parmenides there likens his dialectical inquiry to lbycus' account of erōs, where an old racehorse that remembers the labors of the chariot race is seized by trembling fear (Ibyc. fr. 287). Socrates will express his own fear of erōs at 242c, 254e, and 257a-b.
} 
intensifies Socrates' gentle mockery of Phaedrus's taste for urbane friends and clever flatterers (228a, 229d, 240b). There must be another form of intelligence. Socrates has set the clever arguments and intelligence of these well-known men in opposition to his rustic powers of prophecy. How strange it is for this interrogator of speeches to defer to irrational signs, and the ancient myths and tired cults that infuse the grove. Given Phaedrus's sophisticated impiety, there is much work for Socrates to do if he is to persuade Phaedrus that the speech somehow abused the gods.

Socrates defends the charge of impiety by arguing that if the speeches said erōs was something bad, they must be impious, because Eros is the son of Aphrodite. Phaedrus demurs on Eros's lineage, "So it is said," perhaps because he wishes, liked he did in the Symposium, to place Eros first amongst the gods because of the benefit love gave to a beloved. But he does not object to the argument that a god "or something divine" must be good (242e). Phaedrus could point out that the myths are replete with gods doing bad things, such as Boreas killing Oreithuia or Hades kidnapping Persephone, but that would only matter to him if he actually thought those stories had truth to them. ${ }^{7}$ No, neither speech said erōs was divine, but only a form of desire or experience. For the non-lover, Socrates' interjection of piety and gods is besides the point of determining whether it is better or worse to give favors to a non-lover before a lover. Phaedrus's indifference to the gods, and of course his desire to hear yet another speech, has therefore allowed Socrates to introduce with little resistance what will prove to be a key proposition.

\footnotetext{
${ }^{7}$ Euthyphro is caught in the contradiction that piety is what is dear to the gods while at the same time accepting the stories that they disagree with themselves (Pl. Euthyphro [Euthphr.] 6b-c, 7d-8b).
} 
The tension between the urbane form of speech to which Phaedrus is beholden, on the one hand, and the divine which exceeds comprehension, on the other, now comes to a head. Not only did the speeches sin against Eros, but their "stupidity was altogether urbane" (242e5). The false and "unhealthy" speeches were made for the sake of winning reputation amongst anthrōpiskoi, literally "diminutive human beings" or, more colloquially, "small men" (243a). Something essential to human nature has been diminished by vilifying desire and extolling as virtue the moderation of a hedonistic calculus. Even the concealed lover's commitment to a healthy body was itself unhealthy. Socrates' shame seemed to arise from this diminution of human nature. Health and the fullness of human nature somehow depend on recovering the divine from the sophisticated indifference of men like Phaedrus. It is on account of this illness that the divine becomes something truly needful. Socrates' purification must therefore entail casting off the urbane and merely human speeches that obscure the true nature of Eros.

Socrates tells Phaedrus that there is an ancient ("original," archaios) purification concerning mythology or the telling of myths. This was known to at least one poet, Stesichorus, who recognized that the cause of his blindness was his slanderous claim that Helen went to Troy and was the cause of war. Unlike other ancient poets, Stesichorus was interested in cause and wished to reclaim his vision; his blindness was not a gift but a curse. He was a "devotee of the Muses" (mousikos) in a way Homer, who accepted his physical malady as necessary for his gift, never was (243a). Stesichorus' ability to restore his health was a sign of his superiority to Homer, and Socrates' will follow the manner of his reconciliation with divine Helen: he will give a palinode, literally "a singing back" or "song of return." Stesichorus sang: 
This speech is not true [or: genuine, etumos], Neither did you journey in well-decked ships, Nor go to the citadel of Troy. (243a-b)

The song is explicitly a recantation ("this," houtos, refers to an antecedent and therefore its distance from the hearer, as opposed to hode, which refers to a subsequent and present object) on account of the falsity of the previous speech. ${ }^{8}$ The adjective etumos, "true," is a curious choice, and not strictly synonymous with the alèthès frequently used by Socrates (or Phaedrus for that matter, e.g., when he asked if the myth of Boreas and Oreithuia was true or not [229c4-5]). Its usage suggests truth based on concordance with local traditions and rituals, in the sense of "genuine," and so corresponds with local myth rather than sophisticated and cosmopolitan $\log o i^{9}$ Stesichorus must bring his sophisticated speech into conformity with what exists and is practiced locally, namely those that come to regard Helen as a goddess of beauty or love. ${ }^{10}$ Stesichorus admits the falsity of his speech by restating two key points: Helen's journey and her presence in Troy. The palinode thus preserves the original story in antistrophe, and points to what is actually true. The truth is established through the recognition of a transgression and return from it. "This triadic structure of statement, negation, and recapitulation is the lyric invention of the epode from which Stesichorus took his name: the chorus, having sung stanzas contrary in both lyric and meter while moving from left to right, holds (stêsis) in the middle of the stage to deliver the final stanza. ${ }^{12}$ Such will be the structure of Socrates' own purification.

\footnotetext{
${ }^{8}$ On the poetic usage of houtos in the present passage, see Beercroft 49-52.

${ }^{9}$ Beercroft 56-8. See Chapter II, pp. 23-4 on the distinction between muthos and logos.

${ }^{10}$ Hdt. 6.61; Isocrates, Helen (Isoc. 10) 63.

${ }^{11}$ Cf. Pl. Ep. $3.319 \mathrm{e}$.

${ }^{12}$ Suda "Stesichorus." Also, Philodemus recorded that Stesichorus sang between two armies arrayed for battle and so reconciled them (Stesichorus fr. 72 [Philodamus Music 1.30.31]).
} 
Plato's choice of Helen as Socrates' model for purification thus goes beyond the current fashion of exonerating Helen from her disreputable legacy, as did notables such as Euripides, Gorgias, and Isocrates. ${ }^{13}$ Socrates uses the trope of Helen and Stesichorus' epodal form as an example of how beauty reveals itself. Two Helens are produced, one "phantom" (eidōlon), as Socrates says in the Republic, and the true Helen, meaning that the former, fought over in Troy for ten years, was only a dim shade of the latter, who remains hidden. ${ }^{14}$ This revealing of the truth about the beautiful and bewitching Helen is a structure that recurs throughout the dialogue, and is given a formal account in the art of dialectic, wherein the object of inquiry is found as it stands behind the variety of semblances that dialectic collects and divides. ${ }^{15}$ One example had already been seen in the dialectical unfolding of the soul in Socrates' first speech. Despite these formal similarities, Socrates claims he will transcend and be "wiser" than both Homer and Stesichorus, by delivering his palinode even before he suffers divine wrath. Socrates' prescience indicates that he was not ignorant of the shamefulness of his crime. Perhaps he delivered it in order that he might repudiate it?

${ }^{13}$ E. Helen; Gorg. Encomium of Helen (fr. B10 [DK]); Isoc. 10. Isocrates mentions the long history of antipodal speeches in rhetorical and philosophical circles, and the use of Helen's case in particular (Isoc. 10.2-3, 14-15). Isocrates' polemic against eristic, i.e., disputatious or combative speech, being given a "philosophical" sheen charges that it is useless in both private and public, something Plato addresses over the course of the Phaedrus (Ibid., 10.6). The palinode or epodal structure first articulated here presumably allows speech to transcend the antipodal structure of eristic rhetoric.

${ }^{14} R$. 586c. This account of Stesichorus' palinode - that the Helen in Troy, over whom the war was fought, was in fact a phantom - is corroborated by the fragment of Stesichorus in $P O x y .2506 \mathrm{fr} .26 \mathrm{col}$. i. Herodotus' inquiry is similar, arguing that Helen was held in Egypt whilst the Greeks fought for her in Troy, only to discover her absence after their victory. He makes no mention, however, of fighting for a phantom - Helen was not in both places at once (Hdt. 2.112-20).

${ }^{15}$ The numerous concordances of the Phaedrus with the tradition of the Helen story gives further evidence of Plato's profound ability to gather a wealth of meanings within a single and coherent logos. For example, Homer writes of Helen's prowess with drugs (pharmaka) that suppress all pain and strife - a state which Phaedrus longs for - and that Helen herself was blinded by love for Paris (Hom. Od. 4.219ff, 4.264; cf. Phdr. 258e). 
Socrates' shame has been the thread, or even symptom, that leads from the rule of common opinion in his first speech to knowledge of a higher form of love. This shame was aroused, Socrates tells Phaedrus, by the imagined presence of a noble (gennadas, "well-born") and gentle lover (243c). In contrast to the manifold, colorful, and demotic accounts of erōs in the previous speeches, the noble lover knows of a more orderly erōs that is without jealousy or hostility over petty things. It is in the first place the experiences of noble and rare men that are occluded by the urbane speeches' use of "what is clear to all." The definition of erōs that pleased Phaedrus was a narrow generalization of experiences, which took the erös of "sailors" who "have never seen the love of a free man" to be the whole of erōs (Ibid.).

Like Socrates, the vulgar conception of erōs was also premised on shame directed towards a lover's mad indulgence in bodily pleasures. The thesis of the first two speeches, however, hid an erotic intention, and so revealed their willingness to exploit the beloved's shame without sharing it; their moralizing was insincere and masked their own shamelessness. The experience of shame itself, then, does not presume knowledge nor does it alone distinguish the noble and vulgar erōs; shame has been directed both for and against erōs. Insofar as shame is determined by the esteem of other human beings alone, it is not sufficient for coming to know the divine nature of Eros.

Socrates is constrained to begin his palinode not simply from shame before the noble lover but also because of his fear of Eros, lest he, like the poets, be deprived of his sight. Enjoying whatever honor may accrue from attacking Eros would deprive him of his keenest faculty, the capacity to distinguish genuine and false. Lysias and Phaedrus, who did not fear the wrath of Eros and even presumed to be able to master him, have 
become shameless because of their ignorance of Eros's divinity. ${ }^{16}$ For Socrates' part, he will not claim to be a non-lover and master over Eros, as his shame and fear has inspired him to "desire [epithumein] to wash out the bitter sound with a river of words" (243d). To put Eros in words, to define or "bound" him, is not therefore the sin itself, for logos remains the way by which the divinity of Eros and his mania will be revealed. Eros and desire even inspire a more pure account.

\section{Mania}

The previous speech, Socrates tells "the boy" whom the non-lover earlier addressed, belonged to Phaedrus of Myrrhinous, that is, Phaedrus of a place of fragrant luxury. ${ }^{17}$ The palinode, however, belongs to Stesichorus of Himeros. This new speech of himeros, the ancient name for "desire" that accompanies the Muses (and puns on erōs), will wash out Phaedrus's modern luxuries, and, correspondingly, the word epithumia, which was associated with bodily pleasures in the previous two speeches, disappears. ${ }^{18}$ Rather than refuting the concealed lover's attack on bodily pleasure or desire, Socrates distinguishes an entirely new form of desire; he implicitly agrees with the concealed lover's assessment of epithumia. As Socrates' satiric rendition of the non-lover showed, desire as such cannot be recanted, and now a new form is revealed that transcends the limits imposed upon it by the first two speeches.

Socrates' palinode begins with a repudiation of Lysias' thesis: "the speech is not true [etumos] which says that, rather than to a lover who is present, it is necessary [dei] to

\footnotetext{
${ }^{16} \mathrm{cf} . \mathrm{Lg} .701 \mathrm{a}$.

${ }^{17}$ Nussbaum 211.

${ }^{18}$ See LSJ 830; note its greater frequency in ancient poetry. Hesiod sings that the Muses are accompanied by the Graces and Himeros (Hes. Th. 64).
} 
grant favors to a non-lover, because the one is mad, the other sound-minded [sōphrosunē]"' (244a). Given what was learned from Stesichorus' use of the word etumos, Socrates signals his desire to bring the urbane speeches into harmony with the truth revealed by the divinities local to the plane-tree. But Lysias' thesis has been altered yet again. Socrates has qualified it with the lover's presence. The consequence is that he allows for the boy to give favors to a non-lover when a lover is not present: the boy may initiate a relationship and become a lover himself. Lysias erred, then, not in saying that a non-lover was worthy of favor, but in that the non-lover takes precedence over a lover.

Mania is not "simply" (haploos) and therefore always bad, and its complex nature allows for the possibility of goodness (244a). This entails that mania is itself not the cause of goodness, but rather a medium, and so Socrates adds the qualification that mania is good so far as it "be given by something divine" (Ibid.). Socrates does not deny that madness may be bad, but the examples of good forms of mania indicate the presence of a higher principle as the cause of goodness, akin to how Stesichorus' epode was the measure of strophe and antistrophe and thereby implied a higher principle.

Instead of his prior indulgences of Phaedrus's urbane taste, Socrates turns to opinions that they have neglected, namely those that are old-fashioned, and filled with superstition. The oracles, he says, have all achieved "many noble [or: beautiful, kalos] things," in private or in public, when mad $(244 a-b)$. Like the opinions of the concealed lover, the opinion that these oracles have also done great good is also "clear to all" (244b5; cf. 237d4). The concealed lover used this same appeal to common opinion in order to avoid demonstrating the truth, and so some caution is appropriate here. These opinions would of course be dubious for Phaedrus; it is not clear to all that these prophets 
say beneficial things when mad. How can one be certain that they are mad? Can they feign their mania? Moreover, how can there be consistent human knowledge of the conditions of mania without eliminating the divine source from which its goodness is derived? Is Pieper right to say that mania confounds any attempt to grasp it "scientifically"? ${ }^{19}$ Socrates does not yet offer a definition, a "boundary," of mania, as his concealed lover earlier demanded as the condition for knowing (237b7-d3). For the moment, Socrates is content to supply popular opinions in order to raise the possibility that erōs also provides "the greatest of goods."

The first example of beneficial mania is the mantic art, the art of prophecy, which includes the prophetess at Delphi, the priestess at Dodona, and the Sibyl. These distinct mediums derived their powers from different gods, such as Apollo and Zeus, dispensed prophecies privately or publicly, upon consultation or not, and were inspired through different methods. ${ }^{20}$ All, though, possessed "the most beautiful art [kallistē techne $]$ by which the future is distinguished" (244c). This is the first use of the word techne in the dialogue, and its conjunction with madness, particularly the sheer frenzy of the Sibyl, is puzzling, if art is understood as a solely human endeavor directed by thinking and capable of being taught (270d-e). Such an art of mantic inspiration could only be beyond the ken of the merely human, and depends entirely on divine influence. Indeed, Socrates says that any sobriety is detrimental to the art, to the point that it will accomplish "little or

\footnotetext{
${ }^{19}$ Pieper 56.

${ }^{20}$ There is no definitive account of their various modes of inspiration, but it is known that the prophetess at Delphi was inspired while in Apollo's cave, possibly seated on a tripod and inhaling gases, while the priestess at Dodona apparently communed with a sacred oak tree (Parke 1956 17-25, 36-9; $1963 \mathrm{x}, 3$ ). The Sibyl's frenzied prophecies, which were delivered solely through writings, were of even more obscure origins, involving some form of communion with Apollo, but not complete possession (Parke 1988 7-9, pace Pieper 55-6). Heraclitus wrote that "Sibyl, uttering with maddened mouth grave words, without adornment and perfume, comes out to us from a thousand years with her voice, on account of the god" (fr. B92 [DK]).
} 
nothing" (244b). ${ }^{21}$ Even sacred Delphi did not avoid criticism for its moments of weakness and keen sense for self-preservation, and only when it transcended these human concerns was its authority incontrovertible. ${ }^{22}$ The ancients, Socrates suggests, were more ready to accept the pronouncements of the prophets as divinely inspired, and associated art, authority, and origin with divinity. Moderns, on the other hand, give crude and "high-sounding" names, and assert the power of human sanity and seeking (zētēesis) over divine mania (244c-d). From the urbane exaltation of moderation over madness, Socrates has now gone to the opposite position.

The names of the arts that were "laid down" by the ancients, the mantic and "oionoistic" (the sober and uninspired art of judging the future), have been distorted. Whether or not the etymology of "oionoistic" given by Socrates, that it is compounded from nous, historia, and oiēsis (literally, "intelligent inquiry by supposition"), is historically correct is of no concern, for it could only be corroborated by the wisdom of the ancients (244b). Rather, what is important is that Socrates claims to know the original name that corresponds perfectly with the phenomenon, speech with deed. There are at least two consequences of this. The first is that Socrates maintains the concealed lover's demand for the consistent application of names. The variation of names over time, perhaps as a result of the willingness of speakers to manipulate their meaning for

\footnotetext{
${ }^{21}$ Rowe sees this passage as "doubly ironic," citing the low rank Socrates gives to mantike $e$ at $248 \mathrm{~d}$-e, and the apparently obvious fact that "nor is it even a science (technēe" (172n243c1). The simplistic sense of irony implied by Rowe - that Socrates is lying - means unfortunately that the passage depreciating the oionoistic art is "to be taken at face value" (172n243c5-6). But, if the mantic art is ironic, why not treat the oionoistic in the same manner? Surely Plato is here developing the distinction between mania and sōphrosune as it characterizes divine and human art. Rowe's refusal to countenance that the mantic art might serve a serious function for Socrates entails stripping the whole passage on the beneficence of mania of meaning and purpose (nor could the present appeal to the mantic art be understood as a simple appeal to Phaedrus's prejudices, given his urbane skepticism concerning traditional piety). The apparent contradiction with $248 \mathrm{~d}-\mathrm{e}$ need not be resolved by artlessly eliminating one of the propositions.

${ }^{22}$ On the bribery of the priestess at Delphi, see Hdt. 6.66.
} 
personal gain, underlies the importance of this demand; inquiry requires a consistent object and thus the gathering together and reconciliation of the variety of opinions related to it. ${ }^{23}$ The second is that the modern divergence from the ancients is not a correction, as the moderns suppose, but a distortion. Socrates confronts Phaedrus with the need to defend the superiority of his modern knowledge against ancient knowledge.

The second form of mania that benefits humanity arises amidst the greatest illnesses, which stem from ancient wrath or blood guilt. The symptoms of this great illness are not specified, and although it could be psychic in nature, there is no reason to adopt such a strict division between soul and body, especially since the case of Stesichorus was a physical malady with non-material origins. ${ }^{24}$ Nor does Socrates mention either a specific god that has been offended or any specific crime. This ancient blood guilt has few historical examples, and although Socrates says the illness afflicts "some families," this indefinite diagnosis suggests a general application: great illness might be bestowed upon anyone at any time, so long as we are without foreknowledge and remain ignorant of our ancient origins and the deeds of our forbearers $(244 \mathrm{~d}) .{ }^{25}$ There is an echo of Eleusis when Socrates claims that this mania awakens one to the sacred purifying rites or mysteries (teletai), and indeed Eleusis extended the need for regular purification to the entire city, rather than for certain families and crimes. This purification needs an interpretive mania that resorts to prayers and services directed to the gods (244e). That is to say, there are illnesses that exceed human understanding, and

${ }^{23}$ The Cratylus deals with the problem that the conventional nature of names poses for rational inquiry, as names are subject to a variety of relations depending on the opinions and intentions (and therefore desires) of the speaker (Cra. $411 \mathrm{~b})$.

${ }^{24}$ Pace Pieper 59-60.

${ }^{25}$ The Hippocratic writings discuss a "sacred disease" foolishly treated with purifications and magic, but without mention of blood guilt as the alleged cause (Hippocrates, On the Sacred Disease [Hp. Morb. sacr.] 1.6-10). Nevertheless, Pieper is surely right to connect this second mania to the human separation from the divine origin, and the subsequent distortion of reality, as Socrates describes in his palinode (Pieper 60-1). 
they cannot be remedied by the prescription of moderation given by Lysias and Socrates' concealed lover. In those speeches and contemporary medicine,${ }^{26}$ mania and illness were identical, yet now their distinction allows that not only mania may serve as a remedy, but also that moderation may actively hinder the achievement of health.

Unlike the prophetic mania, this purifying mania is not said to be an art nor does it make use of art in any way. The purifying mania, like Socrates when he arrives at the grove, seems to ecstatically transcend art. It seems to arise form the experience of pain and perplexity, providing the insight that one must change course and interpret the experience out of a desire to cure oneself and become healthy again. This mania derives its value from its dim insight into the past as the cause of present troubles in order to determine a future course of action; its suffering stands in-between the past and future.

The third form of mania, poetic inspiration by the Muses, seems to be quite different from the previous two. This mania works upon a "soft and chaste" soul, arousing it to a Bacchic frenzy with songs and poetry, and then "orders" (kosmein) the "myriad deeds of the ancients" into a whole image for the education of future generations (245a). What can it mean to attribute to the immaterial soul "softness"? The poet's susceptibility to inspiration suggests malleability and receptiveness to the Muses, in contrast to sober and therefore hard souls. ${ }^{27}$ This soft soul recalls the concealed lover's warning that erôs inculcates a softness of body (239c9). Socrates' present attention to souls rather than bodies inverts the relation between the opposites soft-hard, such that, while there, softness of body posed a risk to city, family, and friends alike, here the soft

\footnotetext{
${ }^{26}$ E.g., Hp. Morb. sacr. 1.1-3, 20.1-6.

${ }^{27}$ See Ficino 198182 . In the Symposium, the poet Agathon similarly declares that it is the softness of souls upon which Eros dances, rather than the hardness of bodies. His inference that Eros is therefore soft, however, is contradicted by Diotima, who told Socrates that Eros is in fact "hard and parched" (cf. Smp. $195 \mathrm{~d}-\mathrm{e}$ and $203 \mathrm{c}-\mathrm{d})$.
} 
soul marshals images for their benefit. The improvement of the soul follows a different logic than the body. These two distinctions are not irreconcilable and in fact their mixing allows for four consequent types, including a soft body with a hard soul, befitting Phaedrus, and a hard body with a soft soul, befitting the shoeless Socrates. ${ }^{28}$

Socrates played with this softness in his first speech, when he shared in Phaedrus's Bacchic frenzy, summoned the Muses, and then composed dithyrambs and epic verses. Like the previous forms of mania, the poetic art must be touched with madness, for art alone is insufficient:

He who approaches the gates of the poetic arts without the mania of the Muses, having been persuaded that he will be a sufficient poet from art [technē], is uninitiated [or: incomplete, atelē] and both he himself and poetry, the poetry of the sound-minded [sophronountos] are overshadowed by that of the mad. (245a)

The technician without inspiration, the hard soul, has "been persuaded" that he can become a poet, which in this case is to say that he has been deceived either by himself and his desire to become a poet or by another. Unlike the manic art, where divine foresight and art were one and the same, the poetic art distinguishes mania from techne..$^{29}$ Although poetic mania doubtless exhibits art, the whole is greater than the sum of its techniques. Without this mania, the sober man of technique remains incomplete (atelē), and indeed the mania of the Muses seems to share in the perfecting and purifying power of the mania of blood-guilt (cf. teletai at 244e2). In each case, sobriety leaves one in a state of ignorance as to how the past may inform future fulfillment.

\footnotetext{
${ }^{28}$ Socrates demonstrated great physical endurance and openness to intellectual wonder ( $\operatorname{Smp} .174 \mathrm{~d}, 219 \mathrm{e}$ ff.).

${ }^{29}$ In the Ion, Socrates similarly suggests there are two forms of art, one in contrast to divine inspiration, the other being divine knowledge itself. There, seers and oracles are not spared the epithet "artless" (Ion 534be).
} 
The three forms of beneficent mania share this inspired relation to time - future, present, and past respectively - for the sake of future remedy. ${ }^{30}$ Prophecy alone seems to have no need of the past, insofar as it is truly divine, for it sees all of time before it. The multiplicity of prophecies and oracles, however, and their notorious opacity, indicate human limitations for receiving this divine gift, such that the painful consequences of misinterpretation require reexamining past experience for signs of their truth. ${ }^{31}$ Thus the progression of the three forms is a progressive decay of divine knowledge, accompanied by a perception of this decay and subsequent return to a glorious past. Ficino has rightly noted that there were "no divine hymns until [the poets] were admonished by the prophets and priests. ${ }^{.32}$ As Socrates' shame revealed to Phaedrus, any such admonition must be preceded by impiety rooted in ignorance of the divine.

Socrates' own deeds thus present cases for instructive diagnosis. Each of the three forms of mania seemed to occurred simultaneously when Socrates described his prophetic and purifying shame to Phaedrus, although the presence of each can be differentiated. Socrates reenacted the oracle at Dodona when he heard the voice, the divine breath (pneuma), "from the spot" under the plane-tree, which prophetically revealed to him that he had sinned against Eros. This daemonic voice corroborated Socrates' experience of shame, as discussed above, mirroring the mania that reveals

\footnotetext{
${ }^{30}$ Pace White's suggestion that it is "cognition" that links each form of madness (White 1993 72). Although each entails some form of perception, only the sober and human inquiry into the future (the "oionoistic") is explicitly said to entail the thinking (dianoia) and intelligence (nous) that must accompany cognition (244c7-8).

${ }^{31}$ Herodotus' History is replete with misinterpretations of prophecies that are only correctly interpreted after deeds prove earlier interpretations false. In a famous example, Croesus warmly received the oracle that if he invaded Persia an empire would fall, and that his reign would last until a mule sat on his throne the empire that fell was his own and Cyrus was the mule (Hdt. 1.55, 91). In Plato's Apology, Socrates describes his examination of the poets as akin to examining prophets and oracles: they say many fine things but without wisdom or knowledge $(A p .22 \mathrm{~b}-\mathrm{c})$. Socrates himself claimed to have spent his life interpreting the oracular pronouncement that he was the wisest of human beings (Ibid., 21a-23c).

${ }^{32}$ Ficino 198182.
} 
purifying rites for crimes, i.e., those against Eros. Socrates' shame signaled his entry into the greater mysteries of the grove. The poetic mania seems to have arisen through Phaedrus's Bacchic frenzy, culminating in Socrates' first speech. That speech was itself, however, Socrates' crime - his poetic mania was in that case harmful to him, so he claimed, and did not glorify either the lover or non-lover for the sake of educating Phaedrus, as the poets glorify the ancients. Only the corrective palinode will properly order "the myriad deeds of the ancients." The palinode will be the product of mania, and insofar as erōs is the provider of the "greatest goods," it too will share in the beneficence of poetry, purification, and prophecy.

The cause of beneficence in these forms of mania remains to be seen. Each mania was asserted to be good on the condition that its dispensation was divine in origin, to the extent that any human and sober prophecy, illness, or poetry was useless (244a7-8, c3, $\mathrm{d} 4-5,245 \mathrm{a} 1-2)$. This proposition justifies mania insofar as Phaedrus accepts the earlier assertion that what is divine is in no way bad; but how can something be recognized as divine (242a)? What is the divine? It is first approached by distinguishing it from what is human. Madness allows Socrates to go beyond the probabilities and ordinary expectations of human experience. It is the disruption of the customary hierarchy of goods, such as the hierarchy found in Socrates' first speech. Socrates is consequently able to say that the "fine" or "noble" deeds of mania are the result of disturbance, that is, of "having being moved" (kekinēmenos) (245b). The realization of greater goods depends on being drawn out of an ordinary pattern of goods (265a). By disparaging passive inspiration and mania, the hedonistic calculus and honor-seeking of the urbane speeches precludes the symptomatic experience of "the greatest good fortune" (245c). 
So long as the natures of the divine and the greatest good remain hidden, Socrates" argument that madness is good - an argument reliant on what is "clear to all" remains insufficient. The palinode must extend beyond the assertion of contrary cases and opinions and the contest of ancient and modern authorities. Only when Socrates can show the nature of the divine, and that the madness of erōs is the most divine, will he carry off the "prizes of victory" and his vindication of Eros be complete (245b-c). Knowing full well the immensity of this task, Socrates tells Phaedrus that his "proof" will be disbelieved by the clever but trusted by the wise. What wise man, though, would not also be clever?

\section{Immortal Soul}

The demonstration that erōs has been given to achieve the greatest good must consider the nature of soul. Socrates' formulation of this putative necessity will order the entire palinode: "It is necessary first to consider [or: think, noèsai] the nature of soul with respect to both gods and human beings by seeing its true experiences [pathoi] and deeds [erga]" (245c). The suggestion of studying the soul arises naturally because in his earlier speech mania and erōs were said to be the rule of hubris within ourselves (237d-238a). But it is later shown that this inquiry is presented here as the conscious practice of artful instruction. Socrates later says that should someone wish to teach speeches artfully, he will show to his student "the being [ousia] of this [the soul's] nature" and how it acts and is acted upon (270d-e, 271b-c). Socrates here provides just this "showing" to Phaedrus. Like all arts, the art of speaking is acquired through its demonstration and analysis. The cause of this principle that links soul and speech, however, cannot be fully revealed until 
the nature of speech is brought into question. Socrates is beginning, then, with a principle that could only be the conclusion of the investigation. ${ }^{33}$ Indeed, the announcement of the proof forms a playful, but not meaningless, circle with the proof itself. Socrates says that "The beginning [archē] of the proof is this [as follows]," and goes on to demonstrate how soul is itself an archè. The necessity of thinking the soul seems to originate from and presupposes the soul.

The proof is a remarkably concise demonstration that the soul is immortal (literally "deathless," athanatos) (245c-246a). In eleven sentences, Socrates deduces that soul moves others, but is itself moved only by itself, and so also moves forever so long as it does not abandon itself. As a self- and forever-moving thing, it must be the archē ("beginning" or "ruling principle") of all motion. Being an archē, it could not have come from another arche, and so does not come into being (i.e., it exists but is not generated [agenèton]). The archē of motion is imperishable (or: incorruptible, adiapthoron), for if it were destroyed, it could never again come into being since it was not generated - and if it was susceptible to coming into being or perishing, the entire cosmos would collapse and cease moving, since there would be nothing from which things could again be moved. Therefore, since what is self-moving is immortal, "it would not be shameful for someone to say this is the being [ousia] and logos of soul" (245e). Indeed, the soul's selfmotion is seen from its effect on bodies, which do not move themselves unless they are ensouled (empsuchon).

The proof is problematic from the beginning. Its first words, "all soul is immortal" (psuche pasa athanatos), are ambiguous because there are no indefinite articles in Greek, and here psuchē pasa lacks the definite article $h \bar{e}$. The sense of the

${ }^{33}$ cf. $L$ g. $894 \mathrm{~d}$-e; $R .511$ b-c; Arist. Physics $(P h$ ) 184a 10-21. 
phrase is consequently either distributive, "each and every" soul, or collective, soul in general. $^{34}$ Is Socrates saying that the soul of each individual living thing is immortal? Or that soul, collectively, as life itself, is immortal? Each has significant implications for interpreting both the proof and the remainder of the palinode, and has understandably divided commentators. ${ }^{35}$ Given that the linguistic ambiguity is itself irresolvable, it is prudent to suspend decision for the moment and allow that perhaps Plato intended this perplexity. By doing so, there can be some resolution of the other problems seen in the proof.

This first sentence of the proof is also its conclusion. Socrates, like Lysias, places what comes last in thought first. Even the object in which the motion of soul is perceived - body - is not introduced until the end of the proof, almost as an afterthought. By suppressing this relationship to bodies, and so the distributive sense of soul, i.e., the individual souls that occupy those bodies, Socrates is able to suggest without delay that soul is itself an arche that stands outside all motion as perceived by our senses. Yet even this equation of soul and arche is not explicit. The mediating propositions concerning what is forever-moving and what is the arche of motion are more general and not explicitly linked to soul. Only the conclusions drawn from these general propositions are attributed to soul: soul is self-moving, not generated, and immortal. The burden of the proof is carried entirely by deduction from the distinction between the self-mover and that which can only be moved by another. Socrates thus relies on the distinction of soul

\footnotetext{
${ }^{34}$ The ambiguity of referring to the collective sense of soul as "soul in general" is the unfortunate consequence of the very problem in psuche pasa. Does the collective sense of soul refer to soul as a whole, i.e., a whole of parts, or as a single and indivisible soul, in the sense of one soul? Is soul one or many? ${ }^{35}$ On the ancient debate, see Hermeias $102.10 \mathrm{ff}$. Contemporary scholars are equally divided between the three possibilities. That psuche pasa is distributive, see Griswold 198684 , Nicholson 156. That it is collective, see Bett 919n24 and context, de Vries 121 ad loc., Ficino 1981 6.i, Yunis 2011 136-7 ad loc. That Plato intends both senses, see Burger 51, Ferrari 1987 124, Hackforth 64-5, Skemp 113-5, White 78-9.
} 
from body that he made in his first speech, used to prove the noble intentions of the concealed lover $(241 \mathrm{c}){ }^{36}$

The manner of the soul's motion, both being an $\operatorname{arch} \bar{e}$ and found in bodies, is perplexing. Motion presupposes a multiplicity, such as a change in position or in another property, and is therefore only a monad insofar as it encompasses a two-fold relation of like and unlike. ${ }^{37}$ As such, a self-mover cannot be said to be solely active (its "deeds"), for it is acting on itself, and being thus acted upon, it is passive (it has "experiences" or pathoi, from paskein, "to suffer"); the self-mover presupposes its duality. It is therefore not incorrect to suppose that the experience of mania as "being disturbed," kekinēmenos, is the true nature of soul, but it is incomplete, for that passive reception of the divine can only capture one part of the nature of the soul. The being of soul, which "never abandons itself," lies in its restlessness, always moving itself and being moved by itself (245c9). ${ }^{38}$ The closest physical analogue is centripetal motion, a perfect unending motion toward itself, the circularity of which necessitates its perception through parts. ${ }^{39}$ The perception of the soul as being in motion immediately differentiates it from soul in collective sense or soul as a principle.

Yet the soul as archē thus gives the proof an undeniably collective sense. Hackforth argues that "the logic of the proof" depends on it. ${ }^{40}$ All moving things - and so all things that "come to be" - "necessarily" (anangkē) come from a beginning, which itself cannot have a beginning or it would cease to be a beginning (245d1-2). The use of

\footnotetext{
${ }^{36}$ Sallis 136 . Nicholson is correct to say that soul's self-motion is logically distinct from the motion of bodies, but it remains the case that such purely metaphysical, or "psychic," motions cannot be conjectured until soul's effect upon the body is clarified (162-3).

${ }^{37}$ Pl. Timaeus (Ti.) 36b-d; $L g .893$ c. See also Prm. 138b-139b, 145e-146a.

${ }^{38} \mathrm{Lg} .894 \mathrm{c}$.

${ }^{39}$ Consider the example of the centripetal motion of a symmetrical top, the motion of which can only be perceived by indentifying a part as it moves along with the whole ( $L g .893 \mathrm{c}-\mathrm{d} ; R .436 \mathrm{c}-\mathrm{e})$.

${ }^{40}$ Hackforth 64. See also Bett 916.
} 
anangke here is the clearest expression yet of the nature of necessity, for its assertion is accompanied by a demonstration of why something is necessary: non-contradiction and its correlate, unity. What is must be itself; a beginning cannot have a further beginning. All soul must rest in one soul. This collective soul could be interpreted as a cosmological principle or world soul, in which all individual souls participate and are completed to the extent to which they do so. Although there is no mention in the dialogue of such a soul permeating all individual souls, there must be such a thing as "soul" generally, under which all souls are understood as souls. ${ }^{41}$ Indeed, both human and god alike were said to possess or be moved by souls, and the subsequent myth shows the Olympians moving through the heavens as each "performs what belongs to him" (247a5-6). "All soul" seems to arrange each soul as lesser archai of their respective "provinces of activity," as Ficino puts it. ${ }^{42}$ Socrates thus aptly calls the self-mover the "font" (pēge $)$ of motion, recalling the font of cool (psuchron) water that flows under the plane-tree (230b6, 245c10). This beautiful attempt to reconcile many souls under one, however, founders on the very passage that stimulated it, because the existence of many archai of motion contradicts the notion of $\operatorname{arch} \bar{e}$ itself, i.e., that an $\operatorname{arche}$ as an $\operatorname{arch} \bar{e}$ must be one (245d12). The proof thus points again to the original problem of its distributive and collective senses.

The proof builds upon the demonstration that soul is an arche to show its eternity. Being a beginning, the archē of motion does not come into being, which means it always was, and insofar as it is imperishable, always will be. The correlate "always," however,

\footnotetext{
${ }^{41}$ On this issue, compare for example Ficino, who argues that the rational soul becomes one with the world soul and so "participates of alike immortality," and Griswold, who argues that the only work of soul that is mentioned in the dialogue is the work of individual souls (Ficino 1981 6.i; Griswold 1986 84).

${ }^{42}$ Ficino $19816 . \mathrm{i}$.
} 
is suppressed and not stated. In fact, the verb "to be" (einai) is only ever implicit, and Socrates exclusively uses the verb gignesthai, "to come to be" or "to be born," which can only mean a temporally finite, rather than eternal, being. An archē is in privative relation to "becoming," the world of genesis or change and motion. At the same time, the arche is itself in motion, which, as noted above, means it too is always in a relation. How, though, can this self-mover be in relation to anything besides itself? Moreover, how can it be in relation to itself without the supposition of something - a property for instance with respect to which it changes or moves? This proof of the nature of soul in and of itself depends, then, on a further cause, for the sake of which it moves. What makes possible its movement, or rather, for the sake of what does it move? What is the cause of its being, or, in the language of the Republic, where is "the good itself"? ${ }^{43}$ No such cause is forthcoming in the proof; when soul inquires into itself, it already presupposes the cause of its motion. ${ }^{44}$ The perpetual motion of the self-moving archē necessitates that it never attain and be in conformity with that for the sake of which it moves; were it to do so, it would cease to move, and so abandon itself as something forever- and self-moving. The good for which the arche of motion sets itself in eternal motion is present only as an absence, a lack. $^{45}$

Socrates goes on to prove that an arche is imperishable by conjecturing the consequence of its non-being in the world, that is, on the temporal existence of bodies. Its eternity is proven by the absurdity that results should that $\operatorname{arch} \bar{e}$ cease to be, for

\footnotetext{
${ }^{43} R$. 504e ff. See Benardete 136, Burger 52. Ficino speaks of an "infinite" archē of archai as distinct from the "finite" arche discussed in the proof (1981 6.viii).

${ }^{44}$ This deduction of a further cause is not unique to the arche of motion, but in fact a necessary consequence of all thought and speech (logos), which at least presupposes "to be" (or simply "being," to einai) as a predicate. See Prm. 132a-133a and Sophist (Sph.) 243d ff. The close relationship between logos and the nature of soul is discussed below.

${ }^{45}$ That which is at once at rest and in motion, unchanging, must exist outside of time (Prm. 156c).
} 
another could not come into being (because an archē cannot be generated), nor could anything else, i.e., nothing could come to move again. Without this original source of motion, "the whole heavens and all the earth would come to rest collapsing into one and never again have something from which things will come to be moved" (245d8-e2). ${ }^{46}$ Everything that depends on another for its movement will be incapable of arresting this slowing. An immediate objection suggests itself: if there are other eternal causes akin to this $\operatorname{arch} \bar{e}$ of motion, their being would not depend on the $\operatorname{arch} \bar{e}$ of motion and so the collapse of the physical cosmos would have no bearing on them - they would continue to be as they always have. Although something might continue to be, either this "one" of everything that was once generated or simply eternal beings, the force of Socrates' argument is that such things can only be said to be insofar as generated things, and therewith motion, exist. Our own continuous existence, that we are in motion and temporal, is evidence that the arche of motion still exists, and there is no knowledge of eternal beings except through their differentiation and multiplicity, which is the work of the $\operatorname{arche}$ of motion and generation. The perfect rest of the "one" into which all is collapsed, echoing the one of Parmenides' monism, does not admit of direct perception or knowledge. ${ }^{47}$ The scope of Socrates' claim cannot be overstated, since, by implying the identity of the archē of motion and soul, he is claiming that the being of the cosmos, at least generated being, is coextensive with life and soul. The fact of our being and

\footnotetext{
${ }^{46}$ Accepting Burnet's gèn eis hen rather than genesis, so as to i) preserve the parallel structure te ouranon ... te gën, ii) reject the insertion of the truism that eliminating the arche of generation would eliminate generation, and iii) preserve the allusion to Eleatic monism, described above (pace de Vries 123-4 ad loc.; Hackforth 63n2; Rowe 176; Yunis 2011137 ad loc.).

${ }^{47}$ Parmen. fr. B8 [DK]; Pl. Prm. 132a-b, 141 e-142a. Socrates' proof here is not in opposition to Parmenides, for the apparent absurdity of all things being one points to the distinction between eternal being and the world of motion and multiplicity, transcendence and immanence, and the need to return to the "non-being" of opinion (doxa).
} 
thinking is a premise of not only the proof that the arche is imperishable, but of the very existence of the cosmos. ${ }^{48}$

With this, Socrates says that the immortality of that which moves itself has been shown, and that "were someone to say that this is the being and speech [ousian te kai $\log o n]$ of soul, it would not be shameful" (245e). Socrates does not say that the proof is true, only that it can be justified before the noble and soft souls. It is justifiable in light of the shame that Socrates incurred from his first speech. Although that speech distinguished the soul from the body, it made no claim for its immortality or incorruptibility. On the account of the first speech, the lover aimed at the corruption of both body and soul; the positing of an incorruptible soul would be a bulwark against persuasion that would take possession of the beloved's entire being. Indeed, the dramatic acting out of Socrates' shame served to reveal the soul to be something capable of purification for the crime of putting it in the hubristic service of its corruptible body. The soul is not only independent of the body, but rules the body for the sake of which it acts - this new account has freed the soul in order to show that the madness of erōs can meet the judgment of the noble lover.

Socrates' conclusion introduces the corruptible and perishable body that the proof depended on. The "necessity" that the soul is not generated and immortal requires that the motion of bodies originates from souls (246a1). Socrates has given an account of soul's nature that is as much as possible limited to itself, so that its deeds and experiences are only with respect to itself, distinct from its relation to the world. ${ }^{49}$ Indeed, the eternity of the soul is inconceivable without such a distinction, since the proof depended on the soul

\footnotetext{
48 "Also, any rational soul's power is so great that any one soul in a way may be the universe" (Ficino 1981 6.i).

${ }^{49}$ Griswold 198681.
} 
being an unmoved self-mover. Were the soul necessarily or always an other-mover, its essential being could not be said to lie in self-motion. ${ }^{50}$ The immortality of the soul lies in its eternity, not in the conventional sense of forever being attached to an everlasting body. The deathless gods of Homer and Hesiod are thus displaced from their perch atop the heavens, for what is truly immortal does not come into being; there is no theogony in the palinode. But the true self-motion of the soul is imperceptible, seen only in speech $(\log o s)$. Only the motion of individual bodies, which are in themselves "soulless" and moved "from without," allows the perception of soul in "ensouled" (empsuchon) bodies that seem to move themselves. The nature and cause of this embodiment remains hidden.

The soul's attachment to individual bodies, its distributive sense, presents again the problem of determining whether soul can also be the arche of motion, in the true sense of beginning all motion. The investigation of the nature of soul does not begin in its unity as an arche but in its many instances, while the need for the soul to know itself in order to find its greatest good has returned to that unity. The restlessness of soul, its being in motion, is its active and endless inquiry into itself. Socrates said that "this is the being and speech of soul" and indeed its being and speech (ousia te kai logos) are inseparable. The logos of soul exceeds the boundaries it sets for itself, because the object is forever in motion. ${ }^{51}$ By this mysterious excess, the question of the nature of soul has brought into question the distinction that Phaedrus inherited, between precise logos and ill-defined fantastical myth. ${ }^{52}$ The indeterminate psuche pasa remains, then, the best representation of the nature of soul, and it is fitting that Socrates concludes his proof with

\footnotetext{
${ }^{50}$ Benardete 136.

${ }^{51}$ Cf. Tht. 157a-c, $182 \mathrm{~d}-183 \mathrm{c}$.

${ }^{52}$ Griswold 198683.
} 
the individual soul, where the search of soul into itself for its own nature keeps it in motion.

\section{Form and God}

The proof is sufficient with respect to the immortality of soul, and now, Socrates tells Phaedrus, one must speak of its form or idea. The ousia and logos of soul found in the proof is an incomplete account of the nature of soul without this supplement that harnesses the soul's immortality as the archē of motion to the deeds and experiences of both divine and human souls. "Form" does not here refer to what has been called Plato's "theory of forms" or "doctrine of ideas," although it is unquestionably related. Idea, and the related eidos, is a substantive formed from the verb eidon, "to see," with its aorist aspect denoting a singular occurrence, and so means "a thing seen" or "a look." Form arises, then, in generated things, in the objects of sense, and yet is plastic enough to describe the manner by which soul is apportioned so as to be soul. ${ }^{53}$ In fact, in the Phaedrus, the highest objects of contemplation are never referred to as "forms," ideai or eidoi, a term reserved for objects of sensation or what is in motion, e.g., soul, where form is most manifest. Socrates says that to tell "what sort" of thing the form of soul really is would be an "altogether divine and long narrative," 54 while it is within human capacity to show what the form resembles (eoika) (246a). This does not mean that the long way is impossible, but that it is incomparably more difficult, as Socrates will later tell Phaedrus

\footnotetext{
${ }^{53}$ When Parmenides asks Socrates whether there is form in things like "hair, mud, and dirt," he is emphasizing how form is found in every object of perception, and that Socrates' transcendent forms must consequently be reconciled with these apparently meager instances (Prm. 130c-131a).

54 "Narrative" renders diēgessis, and the only explanation for this unusual word choice is that Plato wished to avoid the more charged muthos, which can also mean "narrative," but could impute fancifulness and a degree of falsehood to what must be "beautiful, wise, and good" (246d-e). On Plato's use of the term mythology, see Chapter I, note 58.
} 
(cf. 273d-274b). The study of soul through a likeness is more properly human in that seeing the form or look of the soul entails seeing it from without - but it can only be seen by a soul, and so falls into the circle of soul looking at itself, "as if in a mirror" (255d). The soul, by looking for its form, has begun working on itself and so moving itself. Socrates proposes an appropriately mobile likeness: "the combined power of a winged and yoked team and a charioteer" (246a). This recalls the charioteer Herodotus of Thebes, alluded to in the prologue of the Phaedrus, whose strenuous exertion of the body would not have been a rhetorically effective image until Socrates depreciated Phaedrus's weak body in his first speech. The soul is not the chariot itself but its capacity for accomplishment and activity, as it is specifically the "combined power [dunamis]" that unifies this fantastical complex of parts, which together recall the chariots and mythical beasts mentioned earlier in the dialogue. ${ }^{55}$ Socrates' earlier warning should be heeded in interpreting this likeness: one should not labor to judge the truth of it on its empirical likelihood. Indeed, Socrates' forthright use of such a fantastic likeness seems intended as a playful counter to the "clever" men who have fed Phaedrus's doubts concerning myth. Socrates is establishing a new ground for likelihood or eikos (derived, like eoika, from eikein, "to be like or resemble") that is not grounded solely in empirical observation. The purpose of the myth of the soul is to transcend the everyday.

\footnotetext{
${ }^{55}$ The image of a winged chariot is not novel to Socrates or Plato, as indicated by the earlier allusions to Pindar's charioteers, the immortal horses given by Boreas and Zeus as compensation for kidnapping their beloveds (Nonnus, Dionysiaca 37.155; Hom. Il. 5.265 ff.), Pegasus and Chimaera, Typhon, slain by Zeus riding in a chariot led by winged horses, and the wild horses of lbycus and Parmenides. Nor would Phaedrus forget Triptolemos, who was given by Demeter a winged chariot pulled by dragons so that he may spread the art of agriculture ([Hom.] Hymn. $2.145 \mathrm{ff}$., 470ff; Apollod. 1.5.2). Drawing on this widely used image of a divinity journeying through the heavens, Plato did not intend his myth to merely reiterate or resonate with any particular one, but indeed to show how all of them originated from the "deeds and experiences" of soul as he describes them. A reading of the palinode that dwells on Plato's use of such imagery and does not consider its transformation and fundamental re-founding misses the basic purpose of the speech. Anne Lebeck's essay, "The Central Myth of Plato's Phaedrus," is of particular note in how she traces Plato's development of images through suggestive repetitions of words and analogy.
} 
Nonetheless, Socrates' warning should not prevent analysis of his own mythical image by questioning how its parts relate to each other, as the further differentiation of the image suggests a specific set of meanings for each new element.

First is the distinction between the soul of a god and a human according to the nature and stock of their charioteers and horses. The gods' are good and of good stock, while the horses of human souls are mixed, explicitly having only a pair of horses, one "noble [or: beautiful, kalos] and good" and the other "the opposite," i.e., ugly and bad (246b). Having these opposites within the soul necessarily makes their teams troublesome and difficult to control. Socrates' description of the human charioteer is curious, literally being "the ruler [archōn] for the charioteer of the team," which suggests a further distinction in the image between the charioteer as a whole and his mind. ${ }^{56}$ The clever question as to whether the charioteer, and perhaps even the horses, are themselves animated with souls such that one soul itself contains several souls, results in an infinite regress with an ever-moving image that defies the unity sought by a likeness, and so can be passed over. A more likely interpretation links the archōn of the chariot to the arche of motion, serving as the origin or font of the chariot's motion, and thus distributing the power of the $\operatorname{arch} \bar{e}$ across each part as the $\operatorname{arch} \bar{e}$ does for each individual soul. The chariot as a whole would consequently be a self-mover in accordance with the archōn.

With this first distinction, Socrates is now able to more clearly distinguish immortal and mortal living things, for the earlier account in the proof distinguished immortal soul from body only on the basis of self-motion. But if a body could be moved forever, i.e., be immortal, it would be impossible to distinguish the soul as the cause of motion. Socrates maintains that soul can be distinguished from the body, for "all soul

\footnotetext{
${ }^{56}$ It is later said that "only the mind of the philosopher grows wings" (249c).
} 
[psuche pasa] cares for every soulless thing and journeys around the entire heaven, at different times coming to be in different forms [eidoi]" (246b6-7). The "all soul" of the proof reappears, with the same complications - does only soul as a whole care for every soulless thing, or does each and every soul? Regardless, soul is not limited by its care for a particular body, as it both inhabits and exceeds the many forms in which it is made manifest. Only Socrates' use of a likeness of a winged chariot has achieved the feat of reconciling soul as one and many. When soul is perfected or complete (telea) and winged it travels without difficulty and "arranges [dioikein] the cosmos," but "the one having lost its wings" is instead carried, that is, passively moved, "until it lays hold of something solid, where having come down to dwell [katoikizein], it takes an earthly body" (246b-c). The body is the home of the imperfectly winged soul, "but it is not immortal from any argument that has been reasoned through" (246c). It is only because of our limited perception of the gods, "neither having seen nor sufficiently thought of a god," that they are imagined (plattesthai) to be immortal living things, with a soul and body combined forever (246c-d). In a stroke, Socrates refutes the Olympians found in the poetry of Homer and Hesiod. The gods as portrayed by the poets are imaginative extrapolations of the life and experiences of human beings, in whom soul and body are mixed together. Knowledge of the soul's movement in its pure and divine form must therefore come from some other source than sense perception alone. The palinode has, however, only proceeded in the opposite direction, a descent from perfection rather than an ascent from the imperfections of embodied life. Nonetheless, beginning from the arche has allowed Socrates the opportunity to demonstrate the full range of motion in 
which the human soul participates, by virtue of its wings, with the upper bounds of that range determined by the gods.

The loss of wings resulted in passive motion, being carried by external forces. Such a soul could not be an archē in the fullest sense described in the proof. The natural power of wing is conversely active and its own source of motion, ranging the heavens and carrying aloft what is heavy. This power of ascent in its full nature has, "amongst the things concerning the body, the greatest share of the divine," which in turn is "beautiful, wise, good, and every such thing" (246d-e). What is similarly divine nourishes wing, while what is shameful or ugly, bad, and "the opposite" of the divine causes the corruption and destruction of wing. Socrates does not mention an opposite of "wise," such as ignorant (agnōs) or unlearned (amathēs). Socrates does not regard his own selfprofessed ignorance to be necessarily destructive of the power of wing (cf. 229e). Although the human soul is not divine, neither is it the opposite of the divine, and it can find a way to become more akin to the divine; its wings could grow again.

The discussion of the nature of wing gives over to the discussion of the souls of gods who, although most akin to the eternal self-moving principle of motion, are shown in the distributive manner which depends on the presence of the body. Socrates dismissed human representations of the gods, but such analogies - when understood as such - prove to be indispensable for depicting the nature of wing. The cause of the gods' power to range the heavens, that is to say, the cause of their fully nourished wings, must be perceived if the cause of the loss of wings is to be understood. Linguistically, immortality (athanatos) is the privation of death (thanatos), but now mortality must be 
understood as the privation of deathlessness; and the nature of a mortal soul can only be understood in light of that perfection.

In the first place amongst the gods is Zeus, "the great leader [hegemōn] in the heavens," who journeys about in a winged chariot "ordering and caring for all things" (246e). Behind him follows "an army of gods and daemons," arranged in eleven further companies (or "parts," merē). A thirteenth god, Hestia, remains in the home (oikos) of the Olympians. The twelve travelling gods "lead as commanders [archōntes] according to the station which each has been assigned" and "do what is [assigned] with respect to themselves" (247a-b). Zeus' station is to order the rest, and in so doing he assumes most clearly the power of self-motion. A rank ordering of souls is established, each owing their station to the power of Zeus. ${ }^{57}$ From this, the gods and their companies proceed along their respective pathways (diexodoi), each a ruler within his or her own station, but not the absolute first principle found in the proof. The purpose of this arrangement is not stated, and no enemy is specified for this army of "the happy race of gods" (247a). Perhaps the enemy is akin to Hesiod's primordial race of titans, out of which Socrates' Typhon, the many-formed usurper, was produced - a kind of gigantomachy between the orderly Olympians and what is monstrous (230a4). Regardless, enmity could only be directed outwards, for jealousy and love quarrels, despite the stories of the poets, are not found amongst the gods, who move as an orderly and harmonious "chorus" (247a). This is no doubt the chorus that Socrates alluded to in his earlier Bacchic mania, and would wish Phaedrus had the aspiration to join. The followers of the gods, however, struggle to

\footnotetext{
${ }^{57}$ Plato asserts for himself such a role in the Second Letter, impudently declaring to the tyrant Dionysius that "if I were ruling [archein] both you and Dion and the others, it would be a greater good for us all and the other Greeks" (Ep. 2.310c).
} 
participate in this chorus, for their leaders easily ascend to their "feast upon the arch of heaven," while they toil mightily on account of the weight of the bad horse (247a-b).

The feast of the gods is played against the "feasting of speeches" furnished by Lysias "over there," i.e., under the earth in Hades (227a3, b6-7; cf. 236c8). Here, the gods will not merely travel to a far away place, but leave behind any ordinary notions of place and feast. Their journey is more akin to Phaedrus's journey outside the colonnades or circuits of the city for the sake of his health (227a2-b1). When they reach the top, "having journeyed outside, they stand upon the back" of the heavens and are led around by its revolution (periphora). They then feast by turning their "gaze upon [theōrousi] the things outside the heavens" $(247 \mathrm{~b}-\mathrm{c})$. Even the gods now find themselves in passive subjection to a still greater source of motion that is perfectly circular in its path. Zeus is not the archē of motion.

The "superheavenly place" of the feast is the ultimate destination of the conversation between Socrates and Phaedrus, yet it is no place at all. Even the poets, who have given so many fantastic and strange images, have not "hymned nor will ever hymn the superheavenly place according to its worth [axios]" (247c). The poetic mania, dedicated as it is to the glorification of deeds, is insufficient for depicting the place here, which has no analogue in deeds and can only be spoken. Socrates only dares to speak, not hymn, the place. The truth (alêtheia) is that the place is "occupied" really is," or more literally, "the being which is in the manner of being" (247c6-7). The difficulty of this rendering lies not simply in translation, but in the nature of speech itself;

\footnotetext{
${ }^{58}$ Literally, true being, "that which really is," holds (echei) the superheavenly place. What Socrates describes cannot of course "occupy" any particular place at all, and so the verb echein avoids predicating position, depth, or other physical properties. Being, as the subject, is what holds the place, i.e., what gathers and orders the elements of the place. The place, in which transcendence is experienced to its greatest extent, is as it is on account of being.
} 
Plato's formulation, hẽ ousia ontös ousa, uses three cognates of the verb einai, "to be," as substantive, participle, and adverb. Indeed, when left un-translated, this formulation more clearly shows its utter circularity, which still hides from sight the nature of being itself. "That which really is" exceeds all description, for its attributes, asides from "being," can only be rendered as privations or negations: it is "colorless and shapeless and intangible" (Ibid.). This entirely transcendent object is that to which "true knowledge relates" and "is seen by intellect alone, the pilot of the soul" $(247 \mathrm{c})$. The full extent of this negation of all earthly attribution is difficult to understate, for the absence of body in the most general sense - all physicality - seems to be death.

The place, though, cannot be nothingness, for the gods are said to partake in what must be something: "the mind of a god is nourished by unmixed knowledge and intellect" (247d). This knowledge is not mixed with "genesis" or with anything "which is different in the different things we now say are," i.e., things which come into being or change, rather than always being ( $247 \mathrm{~d}-\mathrm{e})$. Such knowledge is the nourishment of the mind of every soul, not only of gods', and each "should care to receive what is fitting [to prosēkon] [for it]." The fittingness of such knowledge is not given any specific content, for that would entail mixture, but is simply the principle that it is only with knowledge of what really is, rather than what seems to be, that soul is able to receive precisely what it needs. The mind of a god sees "being [to on] through time with affection and beholding the truth it is nourished and fares well [lit. suffers well, eupathei]" (247d3-4). The precise cause of this "faring well" is not detailed, but amongst the nourishing things, a god is explicitly said to see three things, and he "looks upon justice itself, looks upon moderation itself, and looks upon knowledge itself," as well as "the other beings that 
really are" $(247 \mathrm{~d}-\mathrm{e}){ }^{59}$ Each is the being of one of the four cardinal virtues, although knowledge takes the place of wisdom. This cannot mean that the gods somehow lack wisdom, since Socrates earlier noted that what is divine is "wise," as well as beautiful and good (246d-e). The virtue of courage or manliness, however, is missing entirely. Although arrayed for battle, the bodiless gods seem to have, in their true knowledge, no need of courage. Also notable in its absence is the good, and perhaps it too can be found in the embodiment of soul. But Socrates is in the midst of arguing that "the greatest good fortune" is bestowed through ecstatic mania, and he has claimed that only in the light of transcendent truth does soul fare well. The good is thus hidden again, but, at the risk of repeating the earlier considerations concerning the immortality of soul, the need that mind and soul have for the good, arising from its absence, is made manifest.

Although the mind and soul of a god is completely translucent and hence open to being, it is not itself being, for it knows perfectly of its need for nourishment by what is outside itself. The ecstatic mania of soul finds cosmic expression in the ascent of the gods. The Olympians are not only aware, as one commentator puts it, of the "absent presence" of the good, but are ordered by and reconciled ("with affection") to this perfect knowledge of their subordination to true being. ${ }^{60}$ This is knowledge that they, lacking such being, are themselves not eternal but metabolic. ${ }^{61}$ Indeed, even the gods must see being through time, perceiving that which is outside of genesis, unmoving and unchanging - always being itself - as if it had a past, present, and future. The use of a

\footnotetext{
${ }^{59}$ The threefold repetition of "to look upon," kathoran, emphasizes the independence and enumeration of each being, the purity of which suggests a pun on kathairein, "to throw down" and so "to cleanse or purify."

${ }^{60}$ Benardete 166.

${ }^{61}$ Hesiod said that what did not taste nectar and ambrosia was mortal, "but if the gods lay hold of nectar and ambrosia to exist, how can gods who need nourishment be eternal?" (Arist. Metaphysics [Metaph.] 1000a8-20).
} 
definite article with a participle, on or ousa, indicates that this perpetual duration must nonetheless be perceived in a world marked by change. ${ }^{62}$ The participle, then, does not point to being itself, but back to our own being which is, having been put into motion, the medium for seeing (idousa) being. ${ }^{63}$ When their feasting (hestien) is complete, the gods sink "back into the heavens [and] go homewards"; home is not in the superheavenly place with its view of true being, but back [palin] at the hearth of the cosmos. Hestia alone does not feast, and it is her tending of the oikos that allows for the gods' motion, their ascent and descent. She remains at the centre around which the others revolve while they gaze upon true being. The gods, having ascended from their home, now look back upon it and perceive it as such. ${ }^{64}$ Were the gods to remain forever in the superheavenly place, they would be indistinguishable from the period that carries them and have no need of the horses and wings by which they resemble mortals.

The feast of the gods therefore turns back towards the human souls from which the gods' being was conjectured. The gods' perfect ascent and perception of the truth is extrapolated from a human capacity that is so often hidden. The colorlessness and emptiness of "that which really is" is obscured by "multicolored" feasts such as Lysias", which filled Phaedrus with desires for wealth, reputation, and pleasure (228a3-4, 234d,

\footnotetext{
62 "Being," to on, is here treated as synonymous for hē ousia ontōs ousa $(247 \mathrm{c} 7)$ and merely a difference in quantity from $t a$ onta $(247 \mathrm{e} 3,248 \mathrm{a} 5,249 \mathrm{e} 5)$, all of which refer to true being or being itself (the use of $t a$ onta is more ambiguous outside the palinode). As for the reason why Plato has used the more expansive formulation at $247 \mathrm{c} 7$, it was said above, unsatisfactorily, to be a way by which Plato can show how being permeates, and ultimately exceeds, all forms of linguistic representation.

${ }^{63}$ The gods' vision in the superheavenly place is accordingly expressed in participle form (theorrousa, $247 \mathrm{cl}, \mathrm{d} 4$, and idousa, 247d3), although the use of the aorist participle idousa indicates that Plato was attempting to express, not with tense but aspect, the perception of a perpetually enduring being.

${ }^{64}$ Consider Socrates' playful etymology of Hestia in the Cratylus: "what we call ousia, some say it is essia, and still others osia ... and because we say that which shares in ousia 'is', according to this she would also rightly be called Hestia, for we also seem to have called ousia essia in ancient times" (Cra. $40 \mathrm{lb}-\mathrm{e}$ ). He goes on to point out that despite serious philosophical differences between themselves and the Heracliteans about the nature of ousia, whether it is at rest or in motion, they would have agreed that Hestia is rightly connected to ousia.
} 
236b7). Rather than inducing a divine mania, an enthusiasm, for the attainment of true clarity understood as the soul's translucence to true being, Lysias sought to please his audience with the promise of things that he found to have so much purchase in the city. Ibycus' verse was prescient, for the very things that are valued in the city obscure what is truly needful.

Once home, the god's charioteer dismounts, and having harnessed his team he throws to them "nectar and ambrosia" (247e). Socrates" subordination of the poets" Olympians is now complete, as what was once called the food of the gods is now fit only for their horses. ${ }^{65}$

\section{Mortality}

The grand and orderly ascent and descent of the gods is followed by the chaotic and partial ascent of those in their train, particularly human souls that ultimately descend into the body. The rhythm of the palinode emerges more fully now as a series of cycles of ascent and descent, at least seven in number. The human souls, being inferior to the gods, followed a different rhythm, and even though "the best" amongst them resembled (eikasmenē) god, and "lifted up the head of the driver into the outer place, and was carried along with the revolution [periphora], the charioteer was interrupted by the horses and scarcely looked down on the beings [ta onta]" (248a). The superlative human soul establishes the limit of the human soul, and although it breaks through to the superheavenly place, it still sees far less than did the gods. The human soul does not see $h \bar{e}$ ousia ontōs ousa in its full expression, but only fleetingly glimpses some of the beings (249c4). This limitation and imperfection is the origin and highest form of eikos,

${ }^{65}$ e.g. Hom. Il. 5.368, Od. 9.345-59; Hes. Th. 639-42. 
likelihood, in the myth. Semblance and likelihood is established not on the basis of our experiences and opinions, from below as it were, but from what are truly the highest things, from above. Socrates has inverted his earlier observation that we imagine the gods in our own image; in truth, we are in the image of gods.

The proximate cause of this imperfect imitation of the gods is the quality of the chariot's horses. The best mortal soul struggles with both horses, for the bad horse has effectively disturbed the good one, and the horses must be forced (biazesthai) to lift the driver's head outside the heavens (248a5). The driver must resort to violence and compulsion, not words or other enticements, for there is an irrational element in the soul, as the concealed lover saw. Phaedrus himself had unwittingly been the model for, or rather imitated, the driver - the intellect - when he compelled Socrates to give another speech. Socrates' goading of Phaedrus into threatening force allowed Phaedrus to elevate his desire to the utmost, to take control in the belief that he knew what was best for himself and Socrates. This of course was mistaken, and Phaedrus was forced to take responsibility for the bad speech (236c-d, 244a). Phaedrus's leadership had "dreadful" consequences, but was, as discussed earlier, instructive.

The other souls, the souls which will not take the life of a human, "follow them up whilst yearning, but being unable to ascend, are carried around together below the surface [lit. underwater, hupobruchiai], treading on and laying upon one another, each endeavoring to be before the other" (248a-b). The yearning of the souls for a glimpse of true being intimates the origins of erotic life in the lack of nourishment. This absence has left minds enfeebled, unable and unwilling to hold their stations like the gods - they live in a disorderly competition that is wholly absent amongst the perfectly ordered gods who 
know that their given station is exactly what is best for their natures. The struggle within each soul to reign in its horses has now broadened into a struggle between souls. Disorder originates from the soul, not from the nature of being or the cosmos. Socrates uses the language of water in juxtaposition to the gods' easy ascent through the clear air of the heavens to represent life in the world of motion and becoming: "the competition generates great sweat [hidrōs]" (248b1-2). Water (hudros) comes from within them and they overflow with life. Rather than a charioteer who simply follows the gods and reigns in his horses, the intellect was also for a moment called a "pilot," someone who must navigate his own course (247c7). ${ }^{66}$

Without a glimpse of being, "all depart unperfected [or: incomplete, atelē]" and come to "desire [lit. be in need of, chrōntai] nourishment in opinion [doxa]" (248b4). Without seeing true being "where it is," i.e., by mistaking what is false for true, these souls will not know what is good or fitting for themselves. The "great earnestness" or "seriousness" with which the souls have sought to ascend beyond the heavens was due precisely to the nourishment provided to the best part of the soul. Only in this ancient time before the birth of soul in body is all soul knowingly animated by desire for truth; from here on most souls will be satisfied with its pale imitation in opinion and what only seems to be true. Phaedrus's own seriousness was born from the latter, as he was seduced into defending Lysias' speech as if it were whole and perfect in itself (234c235b). Eagerness for what is false means turning from that by which the wings of the soul are "made light" and akin to the transparent beings in the superheavenly place (248b-c).

${ }^{66}$ Iamblichus, On Timaeus fr. 87 [Dillon 254]. 
Now the journey of soul has returned to the point where the journey of the gods ended. Rather than nourishing their horses and going home, the souls are cast down by Adrasteia, literally Inevitability or Necessity, into mortal lives and bodies. Their home is in these bodies which must also be actively nourished as vehicles for our minds. The cycle of ascent and descent has been repeated, and now mortal life grows organically as soul descends into body and the "now." The "ordinance" (thesmos) of Necessity is more clearly a command or stricture than nomos ("law" or "custom"), and lays down that "whichever soul becoming a follower to a god should look upon something of the truth, is free from sorrow until another period [periodos], and should it be able [dunesthai] to do this forever, it would be forever unharmed" (248c). The soul which, through "some misfortune [suntuchia]," is unable to do so, becomes heavy and "is filled with forgetfulness [lēthē] and badness" (248c6-7). The cause of a soul's lack of power is mysterious in this mythical and ancient time before birth, and can only be ascribed to chance (tuchē). Despite the eagerness with which souls attempt to ascend to the superheavenly place, they are unable to choose their natures and powers. Both power and chance assume a role that was unseen in the life of the gods and produces an unpredictable variation amongst souls. ${ }^{67}$ It would seem that nourishing wing provides the "power" of the soul, but if wing is only nourished by truth, how can mortal souls ever find their way back? Socrates has only depicted the fall, and he will have to show how mortal souls can, in the present (he often refers to the "now") recover their original or natural state. Something of the divine nourishment must remain in the mortal and embodied soul, or be found in what seems to be true, doxa, in order that the soul can be aroused and ascend again beyond the heavens.

${ }^{67}$ E.g., dunamis only referred to the nature of wing $(246 a 7,246 \mathrm{~d} 6)$. 
The soul is "weighed down" beyond the uplifting power of the wing, with the consequence of falling to the earth. The soul does not fall into a body, but is planted: "Then it is a law [nomos] that this [soul] will not be planted into the nature of any beast in its first birth" (248c-d). The body seems only to grow around the "planted" and hardened soul and so become the "seed" or "birth" (gonēn) out of which mortal life originates. Yet because this "first birth" originates from the soul's forgetfulness, it remains a mystery how it can be determined to really be the "first." Since the soul is immortal, how could one know which "birth" is being lived? The first? The thousandth? This first birth, the nature into which the soul is planted and determines the course of our lives, is hidden from us. The ordinance of Necessity is in fact the moment of greatest chance from the view of man in his present life - he has no control over his nature and potential for seeing the truth, but is inescapably bound to it. All that is known is that a mortal soul, akin to a god's, at some point lost sight of the true nature of things but is now able to recall it and see it again. A soul born into a beast could not take on a human life, for some perception of true being is necessary (248c3-4). Human life lies then on a continuum between beast and god, between soul without perception or even awareness of being and soul that sees the whole of being.

Socrates claims that there are nineteen human lives into which a soul could be first born into, arranged into nine ranks according to which soul has "seen the most." There are therefore only nine types of "seed" out of which the lives grow (248d-e). The range of lives proceeds from the highest and first seed, which may produce "a philosopher or lover of beauty or musical [lit. man of the Muses, mousikos] and erotic 
man," down to the lowest and ninth seed which can only produce a tyrant $(248 \mathrm{~d} 3, \mathrm{e} 3){ }^{68}$

There is no obvious correlation between the rank into which a soul falls and in which of twelve companies of gods the soul first ascended, although Socrates later says that only followers of Zeus will become philosophic lovers (252e). So there is a concordance between a soul's nature and way of life or profession in this first birth, but discrepancies may arise in subsequent births. There might be found followers of each god in every one of these lives, and discrepancies may arise between a nature and the way of life it pursues. Until the nature of souls can be clearly determined, it would be a grave misunderstanding to view this hierarchy of souls as a clear scheme for the arrangement of human types in a city. ${ }^{69}$

This does not mean, however, that there is no ranking of those ways of life. The lives of the poet, seer, and sophist really are subordinate to the gymnastic trainer; regardless whether the true nature of whomever lives such a life is suited to it, the life of the trainer is closer to true being. Socrates gives some indication of the reason for this in the structure of the ranks. A division is made between the fourth and fifth ranks. The first four ranks are each introduced with the prepositional clause "into a seed [or: birth]"

\footnotetext{
${ }^{68}$ Within a seed, each life is joined by the conjunction $\check{\eta}$ ("or"), which may be disjunctive (i.e., in

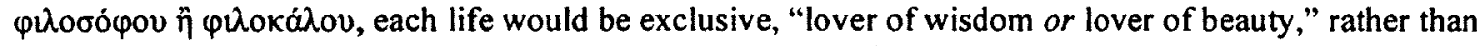
"lover of wisdom or in other words lover of beauty"). De Vries argues it is not disjunctive, at least in the first two ranks, and that these are attributes of a single seed (143n248d3-5). In the case of the philosopher, the two other lives are surely contained in the philosophical life - Socrates describes the philosopher's love of beauty (279b-c), his erōs (249c-d, 252e-253a, 257a), and his devotion to the Muses (259d). But de Vries ignores the attributive participle genessomenou ("into the seed of a man who will come to be") that in the future tense indicates potential, i.e., the potential for the seed to become one life or another. There is no need to preclude the possibility of distinct lives originating from the same seed; the palinode establishes the kinship between philosopher, beauty lover, and musical man, and their unity in the philosopher is possible, but not necessary. There are lovers of beauty and erotic men who are not philosophers, and indeed without the logismos characteristic of philosophy, these two lives appear very susceptible to mixing their pederasty with sex (256a-e). See Koritansky (39n14), though his concern with preserving the philosopher as such (e.g. a philosopher who does not mix this way of life with pederasty) passes over the implicit claim of Socrates that the philosopher, as the perfection of human life through knowledge, is also the best lover. ${ }^{69}$ Contra Hackforth 83; cf. R. 413d-414a, 546e-547a.
} 
(eis gonen), but the fifth through ninth ranks are introduced in apposition with "will have a life" (bion hexousan). The fourth rank is a turning point in the hierarchy of souls, and it is the only one explicitly concerned with the body. ${ }^{70}$ Although the vision of the beings is of non-physical things perceived by mind alone, the one who cares for the body and its health nonetheless saw more of the truth than other revered positions. The ranks below the fourth are no longer concerned with what really is and is beneficial.

These lower ranks of soul are in fact dim reflections, poor mirrors, of the higher ranks. This will lead to their conflation in political life. The politician's reflection by the demagogue and sophist is a case in point; although one is "political" in the full sense of being devoted to the good of the city, and the others curry favor with the demos for the sake of profit, the inevitable mixing of the two will result in the popular disdain for the "politician." The poet, the imitative man, similarly sits in the sixth rank as a crude counterpart of the musical man who is akin to philosopher - they would only be distinguishable to one who can recognize what is truly "musical." Poetic mania, the third form of mania discussed earlier, is now of questionable worth. So too is the first, for the prophet (mantike $)$ has been relegated to the fifth rank alongside the expert in mystic rites (telestikos). Socrates therefore indicates that a revision of his earlier defense of mania is required. Perhaps the higher relation to the Muse is one without the Bacchic frenzy of poetry. Likewise, Plato draws a distinction between the more humble prophetic powers of the soul and the mantic glimpse into the future given by the gods to such popular figures as the Pythia. A clear vision of the nature and origin of one's soul, realized to the fullest extent by the philosopher, is a superior glimpse into the nature of the cosmos.

\footnotetext{
${ }^{70}$ The number four is associated with solids, the adding of depth to a shape (R. 528a-b; Ti. 31c-32c).
} 
The tyrant is the sole life in the ninth rank, which is unique in this hierarchy. Although he may be a disordered swarm of Typhonic shapes, the "multicolored and many-headed beast" depicted in the Republic, ${ }^{71}$ the singularity of the tyrant in the ninth rank signifies that this soul is so completely closed in on itself and distant from true being that no real differentiation of similar lives is possible. The sheer chaos and disorder of this life paradoxically makes it unique. Whatever order is found in the soul and life of the tyrant is a crude image of the soul that becomes the lawful king.

If the rank order of souls, according to how much they glimpsed of true being, also reflects their relative concern with what really is, the preeminence of the philosopher means he is the one most concerned with what is truly beneficial. It is surprising then that he is ranked above those expressly political lives in the second rank, "a lawful king or one fit for ruling [archikos] and warlike," or third rank, "a political man." The highest rank of human being pursues a life of private concerns, of wisdom, beauty, music and erōs. There is no philosopher-king, at least not in this first and most natural life in accordance with Necessity. If the philosopher-king is still present to Plato's mind, it is therefore not a natural destiny of the soul. ${ }^{72}$ The philosopher-king would be an accommodation to the political and bodily demands that arise when one's nature, the grasp of truth reflected in the first birth, has been forgotten. Indeed, a fundamental division is drawn here between the erōs found in the philosophic seed and the political order made by the king who abides and rules by law. Perhaps the highest law which the king could aspire to lay down in writing so as to order the city would be that of

\footnotetext{
${ }^{71} R .588 \mathrm{c}-\mathrm{d}$.

${ }^{72}$ There is no reason to assume, in a biographical or developmental manner, that Plato's omission here of the type "philosopher king" is a repudiation of it as a failed hypothesis following the disappointments of his venture in Syracuse (pace Voegelin 3.192).
} 
Necessity, which assigned lives according to their perception of truth. But the king himself is not amongst the most far-seeing of souls. His law could decisively misconstrue the order that the philosopher perceives to the fullest extent possible for a human being. The later pairing of Zeus with philosophy, and not with the kingly type, suggests a disjunction between the divine order of the cosmos and the political order found on the earth (similarly, sixteen of the lives refer to professions, as the suffix -ikos indicates a man of skill) ${ }^{73}$. What is erotic is more indicative of the highest order (cf. 249d-e, 256e3-257a2). Likewise, the inclusion of the archikos deliberately recalls that the $\operatorname{arche}$ of motion was itself subordinate to and acted for the sake of something still higher. The law by which the king wishes to order the city is, in the end, subordinate to the law that perhaps only a god could know. ${ }^{74}$ A man of the kingly seed, if he is to rule and move others correctly, which is to say if he is to rule in accordance with what truly is, must himself be open to a higher life concerned with the nature of being alone.

It is tempting to locate Phaedrus within this rank ordering of souls and lives. He appears, though, to be a compound: he is a lover of beauty, friendly with physicians, enjoys the company of poets, sophists, and, as seen in the second chapter, is not disinclined towards the tyrant. The fact that the lover of beauty shares the highest rank suggests that if Socrates does not find potential in his friend's soul, he at least wishes to give him that impression. Phaedrus's love of beauty is thus established to be the highest part of his soul. It redeems his lower devotions, such as sophistry and demagoguery which is the principal concern of the dialogue - and sets them against the higher seed of

\footnotetext{
${ }^{73}$ This shrewd observation by Benardete is significant for the relationship between erōs and techne that will be discussed later (143). For the grammar, see Smyth 858.6.

74 "Although they are wise, those you educated as leaders of the city, they will not hit upon the good birth and barrenness of your people, but it will pass them by and they will bear children when they must not" ( $R$. 546a-547a).
} 
the politician, home administrator, and money-maker. Phaedrus's love of beauty and care for the body may allow for this ascent, just as they inspired his ascent from Epicrates' home.

All of these lives may, nonetheless, be lived more or less justly, with consequences for the soul afterwards, as Socrates says each will receive a better or worse "portion" (moira) in its ten thousand year journey of return (248e). Regardless, the ten thousand year cycle is composed of thousand year periods (periodoi), each of which corresponds to one life and the fate of the soul afterwards. These smaller periods are not strictly recurrences of the period of the superheavenly place, as they do not involve seeing the beings, but they are animated by the same desire to return there $(247 \mathrm{~d} 5$, 249a3). The relative rank and vision of being does not therefore determine the fate of a soul, and its ultimate potential is unknown. Only the one who "philosophizes without guile or loves his boy with philosophy" may return to the superheavenly place more quickly, in three thousand-year periods, if it chooses the life of philosophy three times in succession (248e). ${ }^{75}$ The exception of the philosopher is perhaps not surprising, but the equation of "philosophy without guile" and philosophical pederasty is. Pederasty is included for the sake of Socrates' rehabilitation of erōs, but it does not mean that it is exclusive of what some commentators call "genuine" philosophy. ${ }^{76}$ To say so is to deny

\footnotetext{
${ }^{75}$ This entails four lives, the last of which is chosen but never lived. This missing fourth is the possibility of failure, of choosing a non-philosophical life, which could result in spending a "myriad" (ten thousand) of years separated from the true beings.

${ }^{36}$ Gould thinks "without guile" makes no sense unless it is to be contrasted to pederasty with philosophy (making $\dot{\eta}$ disjunctive - "or," not "in other words") $(117,199)$. This means that pederasty with philosophy is therefore philosophy that is with guile, i.e., deceptive and perhaps malicious. This also leaves open the possibility of a philosophy that is asocial, which appears to be Koritansky's view: "the genuine philosophers and those who are lovers of youth along with philosophy" (39). For Koritansky, to equate genuine philosophy with philosophic pederasty "involves just the idolatrous overestimation of beauty indulged by Socrates' myth," but this is difficult to understand, given Socrates' penchant for pursuing beautiful boys.
} 
the kinship of philosophy with erōs and its ennobling of that erōs, which is later shown to be the purpose of the palinode.

The judgment of souls after their lives "are completed" (teleutèsōsin) reveals the work of Justice, Dikēe, to be cosmic, if not eternal, in scope. Death (thanatos) has no final hold on soul, and instead life on earth is euphemistically "completed" or perfected (teletuein) by participation in the cosmic cycle of soul. ${ }^{77}$ After a thousand-year cycle, some souls are sent to "a prison under the earth [and] pay a penalty" (249a6-7). Others, "having been lightened by Dikē [go to] some place in the heavens" and spend their time in a way "worthy" (axios) of the life they lived while in "the form of a human" (eidos anthrōpou) (249a7-b1). It is in the light of Dike that the true "worth" of a life is determined, rather than in the honors, money, and pleasure extolled by Lysias; justice is not in the first place the judgment of particular acts but a condition of soul. ${ }^{78}$ Judgment concerns the choices of a soul during its life from the moment of its "first birth," and even after life on earth choice is given to decide from an allotment "which life it may wish" to be born into next (249b). This means that the judgment of Dike is already found in one's choice of the next life, since that choice depends on one's experiences in this life - Dike is already at work in the way a soul lives its embodied life. In its descent from and concomitant ignorance of true being, soul is only superficially separated from Necessity, for we are compelled to choose for ourselves what is good and suffer what we must from that choosing. Now it is possible for a soul to become truly active and ascend to a higher life or descend to a worse one.

\footnotetext{
${ }^{77}$ This is the deeper meaning of Oreithuia's otherwise merely euphemistic "coming to an end" (teleutēsasan) when seized by divine Boreas (227c9).

${ }_{78}$ This heavenly reward nonetheless pales in comparison to the worth of the superheavenly place where that which is the cause of all worthiness is to be found (see 247c).
} 
The judgment of Dike and choice of lives reveals the nature of what is human, for the soul must be capable of seeing what really is if "choice" and "judgment" have meaning and are not simply arbitrary action and consequence. What is lower than the human, a beast, cannot take the "shape" of a human being:

For it is necessary for a human to know, according to form [eidos], what is being said [legomenon], by going from the many perceived things [and] collecting [them] into one through calculation [or: reasoning, logismos]; and this is recollection [anamnēsis] of those things which our soul saw then, having journeyed with a god and looked beyond what we now say to be, and raised his head into what really is [to on ontōs]. (249b-c)

The life of the human being is according to its perception of form through calculation or reasoning, without which it would cease to be human, for it comes to know what is by way of the form that gathers the manifold into one. Form does not originate from the human being but is drawn from "what is being said" (legomenon) in the things perceived. The analogy of vision for thinking is disrupted - for mortals, clarity with respect to what really is must be attained not through sight but through speech. There is no presumption, unlike the concealed lover, that speech has an unequivocal power of clarity, but is instead filled with confusion; "what is being said" must be gathered together, and the same thing may be spoken of in one way and "now" in another way (e.g., that which really is versus what is "now" said to be [247e]). The twenty-three lives that were distinguished indicate nineteen perceptions of being of varying degrees of clarity, and so at least nineteen ways to approach "what is being said." It is through speech and conversation with other human beings that we come to know, yet knowing is of the things that are outside of us that give meaning to those words. By relating logismos to being (to on ontōs), Socrates here describes more than just a process of communication, but the very conditions for communication. Every human being must enjoy some vision or knowledge of being if 
meaningful conversation is to be possible, such that calculation or reasoning, logismos, is already implicit in the capacity for speaking. "What is being said" refers therefore not to words but to the being of things as made manifest through logos. Being speaks.

The emergence of logismos is the heart of Socrates' analyses of erōs and rhetoric because it is the way by which human beings apprehend the reality of what is desired. Not just speech or conversation, but reasoning, the gathering together of the many into one, is the "form of the human being." Socrates saw the manipulation of speech in the urbane speeches as a deformation of human nature, since without the full development of the power of logos a soul could not perceive the reality it seeks. It is the unity of form that is sought by the soul that unifies human nature into one, into one "form" (eidos) unto itself, despite the nineteen lives into which it can be born. The use of eidos anthrōpou indicates that anthroppos is itself manifold and needs to be gathered into one ${ }^{79}$ man must inquire about man as the being that gathers. How, though, and into what, can that which essentially gathers gather itself? How can unified form emerge for that which perceives itself to be "as manifold as Typhon"? Socrates has not here given any definitive answer to the problem of what is human, but articulates that problem so as to reveals its depth and intractability. The perpetual self-motion of soul is embodied in the being that is separated from being - it takes human "shape" in opposition to the shapelessness of true being (cf. 247c6, 249b6) - in order to know itself.

In the knowledge that human form is essentially logismos, it is now clear that the premise of the present myth, that soul is an arche and therefore immortal, could only be

\footnotetext{
${ }^{79}$ The "necessity" of this gathering into one is derived from the principles of non-contradiction and unity. These can be ascertained in the proof of the immortality of the soul (245d1-3). More plainly, the unity of form is coextensive with the perception of "what really is" because the beings must be seen as they are by themselves. E.g., if one really perceives justice or knowledge simply, one must see "justice itself" or "knowledge unmixed" (247dl, d6).
} 
the result of Socrates having gathered many souls into one (e.g., 245d2). And yet the arche is also the beginning, the principle, which makes the gathering that is logismos possible because soul also endeavors to find what is fitting. Socrates' gathering of souls under the form of the human is the soul gathering itself. The $\operatorname{arch} \bar{e}$ is both the beginning and the end of human calculation, so that soul, in moving itself, returns to itself. This allows some clarification of Socrates' assertion that logismos is recollection: the soul could only perceive and know what really is if it had at one time seen being; otherwise, its "gathering" would be done at random and could hardly be said to be gathering or perception at all. Socrates says that "it is always through memory [that soul] is able to be near to those things, which being near to a god is divine" $(249 \mathrm{c} 5-6)$. The effect of the myth of the pre-incarnate soul is to establish the conditions for reasoning.

Yet at this crucial moment that connects the divine to the human, the myth points away from itself. On the one hand, the myth weaves together the whole which logismos recollects only in part, and so gives coherence to the fruits of reason. On the other, the logismos that begins from the manifold and fragmentary is the only way to return to being. What is left mysterious is whether logismos can ever achieve a vision of the complete whole portrayed by the myth and recollect the superheavenly place to the extent desired by the soul. Socrates' earlier claim that the mortal soul "scarcely looked upon the beings" and "sees some but not others," in contrast to the soul of the gods, suggests that it cannot (248a4-6). Socrates' myth of the logos thus indicates why an account of the logos must point beyond the logos and become myth, and why myth must become logos if the 
myth is to show what is true and satisfy the soul. The palinode is mythology in the highest sense. ${ }^{80}$

Although human nature is said to lie in the logos, and all humans therefore participate in it, it is nonetheless on account of the logos that the philosophic life is said to be superior. Socrates says that "justly only the mind of the philosopher grows wings"; the philosophic life stands beyond even those born with equal visions of the beings, the lover of beauty and the musical and erotic man $(249 \mathrm{c})$. The philosopher alone is able to gather so as to "recollect" in the truest fashion, "using reminders rightly" to grasp the beings. That is, he reasons best. In seeing most clearly what every human soul has seen to some extent, the philosophic life does not transcend the human, but is the human life par excellence. The philosopher nonetheless seems to stand infinitely far from the human, for his recollection of true being, which is "colorless and shapeless and intangible," must confront and be set against the ignorance of the many that manifests itself in "what we now say is." Humanity dwells in the manifold of perception but without understanding or recollection, for it uses names solely as reminders of these perceptions, rather than as reminders of what really is. What we say (phamen) is not what is said (legomenon); we do not speak what is spoken by being. This "now," the "present," the "modern," in which man lives must not be construed to mean merely the dramatic date of the dialogue, the corrupt state of Athenian intellectual and moral life circa $415 \mathrm{BC}$, but rather the perpetual present separation from being experienced by every soul that takes the form anthroppos. The mythical "then" before our birth is the

\footnotetext{
${ }^{80}$ Friedländer's apt formulation is worth repeating: "Socrates ... in the last phase [of the palinode], the erotic mania, unfolded the myth out of doctrine" (1.192). To this the qualification should be added that the "doctrine" is of such a nature that at its heart it subordinates logos to divine being and truth, and so reawakens the possibility of true myth.
} 
eternal unity of being and form to which the logos directs us, which is the essential condition for human life but only experienced as a separation and hence forgetfulness. The myth of soul has placed the eternal in the temporality by which we must perceive things, giving a beginning to what never came into being and will never perish.

In this recollection of the eternal, which is to say, this making manifest what already and always is, the philosopher is separated from his peers. Only the philosopher, "standing outside [ekistamenos] human seriousness" will be "perfected" by glimpsing being again $(249 c-d)$. The typical human concerns, what are no doubt directed towards the immediate needs and desires of the body, are now treated with a sense of play. As seen earlier, the objects of value listed by Lysias, which were taken with great seriousness by Phaedrus, all pale next to the true goods which must be the object of true seriousness for the soul. The philosopher, as the human life most essentially human, separates itself from the apparent home of human beings, the body and what seems to be true, i.e., opinion. In this enthusiasm, understood literally as "having the god inside" (enthousiaszein), the philosopher, the one who is most essentially human, "has forgotten the many" that dwell only in what seems to be true and so separates himself from what seems to be the home of the mortal soul (249d). On account of this, he is rightly regarded by the many as disturbed (parakinon), although they do not know the truth of their words that the philosopher is moved to return to the superheavenly place. To Phaedrus, Socrates seemed to be "wondrous" and "most strange" or "out of place" (atopos), always ready to walk outside the city although he never does $(229 a 3-4,230 \mathrm{c} 6-\mathrm{d} 2)$. Socrates has thus returned full circle to the mania that erōs shares in. 


\section{Recollection and Eros}

As the palinode continues its descent from eternal being into mortality, it turns to how the soul may ascend in this life. That ascent was a return to being and truth through calculation, which was also called recollection (anamnēsis). Now Socrates tells Phaedrus that "therefore the whole speech [logos] having come here concerns the fourth mania" (249d). The ancient life of the soul, its ascent and descent, has been an account of the highest or fullest form of mania. The ascent of the gods was a perfection of human potentiality, however, and what is merely human cannot match the grandeur of a soul moved by unadorned truth. The human soul becomes winged when it sees someone beautiful, and though eager to fly it is unable (adunatōn) (249d).

The winged human who nonetheless continues to look upward to true being is "slandered" as being mad (249d). In looking upwards, he "neglects [lit. does not care for, amelein] the things below" ( $249 \mathrm{~d})$. These things below are the things of the earth, the needs and desires of the body as well as the city in which the body is cared for. Care for the body, however, was shown to be the privilege if not function of soul - "all soul cares for every soulless thing" (246b6). Although Socrates praises the soul that longs to return like "a bird" to true being and true nourishment, it will later be seen that that longing is not without its dangers.

Despite this danger, the mania that is induced by looking upon (blepein) something beautiful and being reminded of true beauty is the "best" mania of all (249d). This is the same mania that seemed to fill Socrates while he looked upon (apoblepein) Phaedrus as he read Lysias' speech and threatened to enthrall the beloved $(234 \mathrm{~d} 3$, 239b7). Phaedrus's own inspiration and shining face, Socrates now shows, was a 
reminder or even a "semblance" (homoiōma) of true beauty. Their sharing in this mania was in fact love (erōs) of beauty, the love from which the name erastēs ("lover"), the senior man in a pederastic relationship, is derived (249e). It is through the best mania that a man may transcend the particular beautiful boy he looks upon to reach what is truly beautiful. In complete opposition to the previous speeches and the experiences of "sailors," erōs is now conceived of as solely beneficent, the condition of soul that leads to the vision of true being. This lover was in fact in love before even meeting his earthly beloved, for erōs is participation in truth through the beauty found on earth - it is inbetween $($ metaxu $)$ the pure superheavenly place and the mixed life of the body on earth ${ }^{81}$ - and in its highest form this participation is through speech. This outlines, in principle, the meaning of Socrates" mystifying account of himself as being between the "simple" and "manifold," and that he knows himself through knowledge of Phaedrus. As a desirous being he gathers together, through conversation, his manifold perceptions in order to find what he desires in its simplest and purest form.

Erös is a tension, expressed here in the image of growing "wings" yet remaining rooted to the earth; the ascent of the soul will not be relived on earth in the manner depicted in the myth. Indeed, the coherence of the myth seems to break down now that it is concerned with human life as we find it. Although wings were said to only grow every ten- or three-thousand years to lift one back to true being, now wings grow while on earth $(248 \mathrm{e}-\mathrm{a}, 249 \mathrm{c})$. The great cycle is experienced in the "now," such that the nourishment of truth is found not only in "that place" above the heavens, but can be glimpsed here.

\footnotetext{
${ }^{81}$ The metaxy is described in the Parmenides as the "strange moment" when change occurs that is neither when the thing is at rest nor in motion nor in time, and so reveals "the one" that stands outside of all properties, e.g., outside of rest-motion, like-unlike, great-small, increase-decrease (Prm. 156d-157b). Awareness of and living in the metaxy would therefore be the most direct link to eternal form.
} 
Socrates again insists that "every soul of a human being has by nature gazed on the beings [ta onta] or it would not have come into this creature" $(249 \mathrm{e}-250 \mathrm{a})$. The possibility of ascent through recollection is at once open to all human beings, but Socrates also explicitly restricted it to the philosopher (249c). All human beings have the capacity to recognize and be led by the philosophic life of the logismos even though their nature may not be sufficient to live that life themselves. Even the concealed lover, one might recall, was compelled to a more disciplined use of logos in order that he might gratify his erōs, base as it may have been. Unlike the philosopher, the many, because of either their past failure to see enough of true being or their choice of company, are turned to injustice and "forget what [they] saw then of the sacred things [hiera]" (250a). This forgetfulness is the forgetfulness that brought a soul into a body; the potential for injustice is coeval with incarnation, and so an inevitable part of human life that is the rule rather than the exception (248c7). Only those few who are left with "sufficient memory" of the beings will grow wings (250a).

The souls that can recollect more are most susceptible to the power of being, for they are "struck out" (ekplēttesthai) when they see on earth a "semblance" (homoiōma) of beauty itself, just as was Socrates when he saw Phaedrus (250a6, cf. 234d1). When a man is struck out in this way he ceases to be himself; the "self" and its regular, reliable, and known boundaries are thrown into question before this vision of the truth. The self as such is defined in contrast to truth because it is what is filled up, colorful, and with shape, rather than transparent towards being. The heaviness of the self is the forgetfulness of being that must be "struck out" - this is a very strange picture of recollection, given the common belief that we hold on to our memories as if they were 
artifacts so they do not escape us. Socrates is not saying that "memory" is emptiness, but that our original, best, state is one without forgetfulness and being transparent to being.

A soul dulled to the experience of being struck out, amazed, perplexed, does not perceive a likeness as a likeness of truth, and will consequently maintain itself in its usual manner, secure in itself. Socrates' claim that he still seeks to know himself, that he is ignorant, suggests that he would be in a constant state of being struck out or perplexed $(229 \mathrm{e}-230 \mathrm{a})$. There are indications of this in other dialogues. ${ }^{82}$ But Socrates' experience of being struck out in the Phaedrus was playfully feigned for the sake of showing Phaedrus his inspiration by speeches. Moreover, Socrates also said that because he knew Phaedrus, he had not forgotten himself (228a). How can he be both ignorant of himself yet not have forgotten himself? The only solution seems to be that Socrates knows himself as someone who is ignorant of himself, as someone who knows his own ignorance, which is the suggestion made in the Apology. ${ }^{83}$ Could he really therefore be said to be ignorant? The account of recollection shows that no one is entirely ignorant, for a vision of the beings is a necessary condition for recollection, i.e., all learning and experience that summons the intellect. Recollection is participation in the beings through reasoning, but a life of reasoning is not one of completed thought or the formation of doctrine, rather a life moved to seek the knowledge it possesses only in a preliminary or intuitive fashion; it still seeks completion or perfection, which it can do only because it recognizes its own state of ignorance. ${ }^{84}$

\footnotetext{
${ }^{82}$ E.g., R. 475a5-6, Smp. 174d-e, 203c-d.

${ }^{83}$ "That man among you, $O$ human beings, is wisest, whoever just like Socrates knows that he is in truth of no worth with respect to wisdom" (Ap. 22e-23b).

${ }^{84}$ Griswold calls this intuitive knowledge "mythical understanding," an understanding that, as the condition for logical understanding, ultimately eludes rational speech.
} 
The capacity for recollection is limited both by the powers of the particular soul and its "dulled organs" as well as the nature of the reminders or semblances themselves: "there is no light in the semblances here [i.e., on earth] of justice and moderation and other such things of value to souls" (250b). Socrates does not mention being itself or knowledge, and so what was earlier manifest to the gods has now passed from clear sight. Since a human being cannot with clarity see even justice itself, no more clarity could be expected concerning the whole of being to which "true knowledge relates." With being so obscured, by its appearance in semblances and by our organs, "few who come to the images [eikonas] see the race of the thing that has been imaged" $(250 \mathrm{~b})$. Socrates has transfigured the statue (eikōn) that Phaedrus promised to erect in his image at Delphi into a natural reminder of what is truly beloved.

The beloved beautiful boy is a reminder of what had been seen "then," in the ancient life of the soul, when it "was possible to see beauty shining" as all the souls followed the gods in a "happy and blessed chorus" (250b). Now, moved by erōs, the soul longs to return by recollection to true being and that time when we "were whole ourselves and untouched by evils" (250c). This return is, Socrates says, an initiation in "the most blessed mysteries." Its final stage, the epopteia, is to see "whole and simple [hapla] and unchanging and happy showings [phasmata]" (250c). The properties of these showings differ from the properties of being mentioned earlier, namely shapelessness, colorlessness, and intangibility. All the properties are nonetheless in sharp contrast to life in a body in a world of change and multiplicity. Happiness lies not in the experience and use of the things here, the images and semblances, but in their use as reminders of these whole and simple showings where good things are found unmixed. 
Without Socrates' mythical arrangement of this experience in the past life of the soul, one could be led to believe that the life of a human being is a tragic one of darkness and suffering without reprieve. Socrates does not defend philosophically the natural priority of wholeness, rest, peace, goodness and happiness, as he does in other dialogues, but only implies the need to do so by equating recollection to logismos. Socrates' primary purpose here is to show that although living in the revelation of truth - and therefore not the greatest fortune given through erōs - is beyond the mixed life of the body, it may nonetheless be approximated or approached by constantly purifying the soul of the body's influence that compels it to dwell in what are only reminders. The greatest good fortune that is given through erōs is therefore not the complete vision of the superheavenly place, but the desire to attain it.

Socrates thus initiates Phaedrus into mysteries that recall the Greater Mysteries of Eleusis, although the civic cult of Athens has been transfigured and subordinated to the ecstatic view of the whole of nature through philosophy. The rites of initiation are recollection, the procession of sacred things (hiera) is the gods' vision of the beings themselves, and now in the final initiation, the epopteia, "happy showings" are given and beauty is glimpsed in its radiance. ${ }^{85}$ The rituals of Eleusis, rather than being the model for this ascent to true being, are now themselves shown to be an imitation in deed of what must in fact proceed through reasoning. As an image of philosophy, the old rites are preserved on new grounds, not discarded. But is Phaedrus aware of this? Or does he

\footnotetext{
${ }^{85}$ After the walking of the sacred objects (hiera) from Eleusis to Athens, the initiates are taken back to Eleusis for participation in sacred rites. The sources on these rites, which occur in the temple at Eleusis, are limited and only mention the things "done," "seen," and "spoken" (Mylonas 270; Kerenyi 92-3). The initiate is passive during the showing of further sacred objects inside the temple. Some sources suggest that the epopteia, the final initiation, culminated in the revealing of a sacred flame, which may have also been found in Apollo's temple at Delphi (Mylonas 274-8; Kerényi; Parke 1956 35). Kerényi interprets the flame as that in which Demeter held Demophoōn in order to make him immortal (Kerényi 82; see [Hom.] Hymn. 2.231-41).
} 
only see this as the demystification of ancient superstition? The reenactment of the mysteries is the crime for which Phaedrus and his associates are exiled from Athens, and Socrates has here been his leader in exactly this. Socrates, though, should not shoulder all the blame for the destruction of custom, given that Phaedrus had begun the dialogue already afflicted with impiety and urbane skepticism. For Socrates, the mysteries of Eleusis, though deficient in the use of logismos, have grasped something of the nature of human life as separation from wholeness and purity, with the attendant need for purification. ${ }^{86}$

Nonetheless, Socrates does not give a reverent portrayal of this embodied life, but one both comic and tragic: we are like oysters, carrying around (peripheresthai) our bodies as tombs and prisons (250c). This mixed image collapses together two elements that were held to be discrete in the ancient life of the soul. First, embodied life is a microcosm of the great revolution that carried soul around (he periphora peripherein) the beings (247c5). As soul revolved around and was nourished by being, the body encircles soul. The implication is that the body must find its perfection and nourishment through the order of the soul. The care for the body follows directly from the care for the soul, which goes some way to ameliorating the second element of the image. This second element is that embodied life is imprisonment, the very same curse laid upon unjust souls after death (249a). The punishment for injustice, then, is found in this life as dwelling in the living death of our bodies. But this view neglects that the shell of the oyster also protects its soft interior from being washed away by powerful waters. The dissolution of the body will not in itself deliver the soul to the happiness found in the superheavenly

${ }^{86}$ Cf. Phd. 69c-d. 
place. The palinode continues because the greatest good fortune provided through erōs has not yet been established.

\section{Beauty and Enthusiasm}

The recollection of true beauty places the embodied soul in the tension experienced as erōs, and so it is out of "longing for what was before" that Socrates spoke at length about the nature of recollection (250c). In the next iteration of the soul's ascent, Socrates turns to the source of longing "here" on earth. He discusses the nature of beauty, how humans participate in it, and its effects. Beauty, although Socrates only just introduced it alongside recollection, had also "shone with the other things" in the superheavenly place (250c-d). It is primarily of concern "here," where it is "found glistening most visibly clear through the clearest of our senses" (250d). Sight is the keenest of sensations that come "through the body," and so it is the fate of beauty alone to be "the most manifest" (ekphanes) and therefore "most loved" of the beings. Wisdom (phronēsis), and "the other things that are loved," remain concealed, "for it would provide terrible love if it allowed some sort of visible phantom (eidōlon) of itself to come into sight." Recall that the beings themselves are not called "forms" (ideai or eidēe), a term that Socrates has assiduously restricted to the objects of perception, ${ }^{87}$ with the effect that the experience of seeing beauty is inseparable from the recollection of being (only in the discussion of rhetoric and logos does eidos more obviously take on meanings that resemble Plato's "theory of forms"). Beauty is so loved precisely because of its clear manifestation and visibility - it presents to the senses the wholeness and purity so

\footnotetext{
${ }^{87}$ Albert Cook remarks that Plato uses the terms "casually" in the Phaedrus, but it is certainly conspicuous and significant that he deliberately avoids the usage most familiar to readers of his other works (Cook 441).
} 
beloved in the superheavenly place. It seems to offer a visible and experiential completeness that has so far only been seen in speech, in the concealed lover's use of definition to make clear and delimit the object of desire (237c-d, 238b6-7). It is therefore a vital link to the nature of being.

Beauty thus does us the good service of supplanting a most terrible and dangerous love with love for itself. The danger of the love of wisdom lies in the human inability to take hold of wisdom in its entirety; the direct love of wisdom and eternal being would destroy a mere mortal. The love of beauty must then be relatively innocuous, as it directs us towards the visible things that have so far been called images, phantoms, or reminders, rather than the truth, which is not visible to sight. Beauty is rare in that we can love it for its own sake, such that beauty, perhaps more than any other being, entails the love of its instantiations (what is "eponymous" with beauty itself). ${ }^{88}$ Those fighting in Troy were drawn not by Helen, Stesichorus sang, but her phantom. Indeed, if truth concerning being is obscured, the love of what is beautiful draws one away from the being of beauty itself. Insofar as love is directed at what is beautiful in its visible clarity, it is directed at what seems to be beautiful and not beauty itself, which, as one of the beings, is visible to the intellect alone (250b). The further implication is that the being of beauty, the manner of its being, lies in its concealment of being. The sheer manifest and evident perception of being conceals the nature of being. Nonetheless, Socrates says beauty draws one towards the recollection of being (249d). This apparent inconsistency may be explained as follows. The inspiration which beauty induces for its manifestations, rather than itself, leaves the lover longing for the true source of his inspiration when those manifestations prove to be just that - manifestations that hide the truth. Because of the very falsity of

\footnotetext{
${ }^{88}$ Smp. 204d-e.
} 
these phantoms, the lover is drawn towards being itself. ${ }^{89}$ The attractive superficiality of the beautiful points away from itself. This is what Martin Heidegger means when he interprets this passage as "beauty in felicitous discordance with truth. ${ }^{.90}$ In his brief essay, the most penetrating analysis of the central teaching of the Phaedrus, he explains that "the essence of the beautiful ... is what makes possible the recovery and preservation of the view upon Being, which devolves from the most immediate fleeting appearances and which can easily vanish in oblivion. ${ }^{\prime 91}$ The central concern of the Phaedrus may be said to be how the "showing forth" or "manifestation" (ekphainein) of beauty conceals, for this is the fundamental experience of erōs and therefore essential to understanding the power of persuasion that is built on that experience. Since it is beauty that is manifest to the senses and draws the human being towards its being, "Plato envisages the utmost perfection accorded to man only as an encounter with divine Beauty, not as an encounter with the idea of Goodness or of Being." ${ }^{92}$

For someone who has not been recently initiated into the mysteries of being, this discordance between the appearance and being of beauty means that when he sees a "god-formed face" or "something that imitates beauty well," he will "give over to pleasure" and, like an animal, go "on all four legs to set upon them and father offspring" (250e). This pursuit of sexual pleasure and reproduction is, after chance and lack of power in the human soul, the third cause of the soul falling away from true being. Socrates describes it as hubris that is without fear or shame and is "contrary to nature"

\footnotetext{
${ }^{89}$ In the Symposium, Socrates cannot explain to Diotima what it is for the sake of which beauty is desired, but he has no difficulty answering the same question concerning the good (Smp. 204d-205a). Pieper comments that beauty does not make us content or satisfied, "even on the most spiritual level" (85).

${ }^{90}$ Heidegger 1991197.

${ }^{91}$ Ibid.

${ }^{92}$ Pieper 83. Cf. Smp. 210e-212a.
} 
(251a). Socrates has returned in even stronger terms to the definition of hubris given in his first speech. The desire to reproduce or "beget upon the beautiful," as Diotima says in the Symposium, that seems to be common to all living things is considered unnatural, at least for a human, whose shape and form is the consequence of having glimpsed true being. ${ }^{93}$ Dwelling in the pleasures of the body and producing bodily offspring is a diminution of human nature and even erös - it belongs to the "small men" who do not see the divinity of erōs (242e-243a). The true deficiency of this erōs is only seen in light of the experience of the newly initiated man who feels "fear" and "shame" when taken by the desire for bodily pleasure. This also means that the experience of the new initiate must contain the seeds or potential for degradation.

The new initiate is fearful on account of the "reverence" he has for the beautiful body, and also fears having "the reputation [doxa] of madness" (251a). His fear and shame therefore originates from divine and human sources. With respect to the latter, all humans are nourished, to some extent, by opinion (doxa) and their recollection of being through speech, so the opinion of the community as a whole carries enormous weight with those not blessed with true knowledge. The forgetfulness of the many shows itself in the opinion, first seen in Lysias' speech, that would restrain the lover from "sacrificing to his beloved as if to a statue and a god" (251a; cf. 248b4-5). Since Socrates is attempting to fashion an antipode to the urbane speech, he does not mention that this opinion could also restrain those who would otherwise go on all fours towards their beloved. The power of reputation consequently produces an incentive to hide this reverent madness if one wishes to ensnare a beloved who is ruled by fear for his reputation - as Lysias clearly saw. That fear of course obscured the divine fear instilled

\footnotetext{
${ }^{93}$ Smp. $206 \mathrm{e}$.
} 
in the lover by the ecstatic experience of recollection and love, which Socrates now describes. ${ }^{94}$

This experience is now "an expected change [metabolē]," a disturbance of the regular motions of life that produces symptoms of illness, including sweating, fever, itching, and throbbing aches $(251 \mathrm{~b}-\mathrm{d})$. The diagnosis that Socrates provides is in the manner of the Ionian physicians, analyzing the motions of bodies as they are acted on and act on others. Its resemblance to the physiological account of mania written by the Hippocratics is not accidental, as Socrates ironically reverses the demystification found in their The Sacred Disease by using a physiological account of sight to depict the disturbance of the soul. Rather than madness arising from a failure to breathe, madness arises from a failure to remain open to beauty; rather than producing a need to discharge phlegm, there is a need to discharge a stored perception; rather than a melting of phlegm, there is a melting of the base of the wings; and so on. ${ }^{95}$ But Socrates' physiology of erōs is not merely analogical, as it indicates that the lover's participation in beauty, the motion of his soul incited by its separation from the beings themselves, is also the cause of the motion of the body, both local motion and metabolism. ${ }^{96}$ Unlike the Hippocratics, Socrates' understanding of the body entails understanding its non-physical causes. ${ }^{97}$

The lover receives through his eyes the "flowing off" of the beautiful, which is the nourishment of the plumage of his wings (251b). The "outgrowth" or base of the

\footnotetext{
${ }^{94}$ Shame is one part or kind of fear, as it is linked to a fear for one's reputation (Euthphr. 12a-c).

${ }^{95}$ Hp. Morb. sacr. 6-8, 9.10-12, 13.7-10.

${ }^{96}$ The two basic forms of motion (see Lg. 893c; Prm. 138b-139b, 145e-146a; Ti. 36b-d).

${ }^{97}$ Consider the author's emphasis on the brain, which must remain open to the external world and freely circulating phlegm if intelligence is to be produced, as well as on the need to study causation in order to discover cures (Hp. Morb. sacr. 10.46-54; 20.12-16). These affinities suggest that Socrates found such diagnoses to be not wholly without merit, but incomplete or reductive. Socrates is rarely dismissive of the expertise of physicians, which is frequently seen as a model art analogous to philosophy - and the body is after all the object of care for the soul. On Socrates' rejection of the physiological explanations of Anaxagoras, see Phd. 97b-99d.
} 
wings that had become dry, hardened, and closed, is now watered and melts and opens. As his feathers "begin" (archein) to grow anew, the swelling of the quills induces throbbing and "itching" (knēsis) that initiates the soul's motion (kinēsis) towards the holder of beauty. The bodily motion produced through erōs is the performance of the soul's power as archē of motion. ${ }^{98}$ Growth and fulfillment of the soul's winged nature, its ascent, requires this openness to being, which is literally a taking part in. The wholeness of true beauty, earlier said to be pure with respect to itself, is now understood as a whole of parts. Its division must be due to the particularity of the receiving organs, for the whole of true beauty cannot be limited to a particular space or time. When looking upon (blepein) the beautiful boy, parts (merē) of beauty "come [ep-ienai] and flow $[r h \bar{e} n]$ from there" (251c). Phaedrus would see that this account closely resembles Empedocles' influential hypotheses on respiration and perception, albeit playfully compounded by Socrates into the experience of himeros, desire, understood as openness to the reception of being. ${ }^{99}$

While the lover gazes upon the beautiful boy, "he rests from the pain" of growing wings "and rejoices," but when the lover comes to be separated from the beautiful source of nourishment himeros becomes painful (251c-d). The base of the wings "becomes parched" (lit. "unwashed") and the "passages," diexodoi, through which the quills grow out now close and harden (251d) ${ }^{100}$ The nourished "shoots" of the feathers, straining to be released from this imprisonment, "sting" the soul. The full meaning of this is not

\footnotetext{
${ }^{98}$ Benardete 134.

${ }^{99}$ See Empedocles (Emp.) fr. B84, B89, B100 [DK]. See also Pl. Meno (Men.) 76c-e.

${ }^{100}$ The Greek is ta tōn diexodōn stomata, which resonated greatly with Ficino, no doubt because of its prefiguring of the stomata of Christ, as well as the sharing of his blood in the sacrament of Eucharist. Ficino writes of this exchange of mere as the exchange of blood: "vapor produced by the heart of Phaedrus immediately seeks the heart of Lysias, through the hardness of which it is condensed and turns back into the blood of Phaedrus as before, so that now the blood of Phaedrus, amazing though it seems, is in the heart of Lysias" (Ficino 19857.4 [159-61]).
} 
evident without recollecting the life of the gods, who traveled by many diexodoi ("pathways") in their ascent outside the heavens (247a). The lover, full of himeros, has gods inside him - the original meaning of "enthusiasm" - that move him to return. As Benardete says, "God is wing," and so it is through erōs that a human gains the wings of divinity. ${ }^{101}$ This pseudo-physiology of erōs is therefore a microcosm and macrocosm of the ascent and descent of the souls; the life of soul has unfolded over the course of the palinode in successive iterations, and each iteration compactly contains or rather implies the whole. That is to say, the form of the palinode as a whole is implied in each part. This particular iteration shows the form to be what was earlier called "the form of the human." This means that if the human soul could be plumbed to its fullest extent, that enquiry would reveal the structure or form of the cosmos, and conversely, inquiry into the nature of the cosmos demands inquiring into the nature of oneself as the subject that shares in its object. Knowledge of the cosmos becomes coextensive with knowledge of soul. Should the diexodoi of the soul be closed, this would mean being closed off to the divine, to participation in true being, and therefore to self-knowledge and the natural flourishing of the wing.

Socrates, by repeating the process of the lover's perception and then separation from the beloved, this opening and closing, growth and decay, pleasure and pain, reveals the rhythmic pulsation of the soul to being itself. ${ }^{102}$ This is actually experienced

\footnotetext{
${ }^{101}$ Benardete 138, 141.

${ }^{102}$ The interpretation of this process as a consequence of pulsation by both the subject and "being" cannot be substantiated by the text. For example, Voegelin writes that "we immerse ourselves in mania in the Agathon and, reversely, in mania the Agathon fills the soul. All such formulations, however, are inadequate because the language symbols distinguish between soul and idea, while in fact the process should be understood as an impersonal pulsation of the cosmic force, a flow and ebb of the cosmic rhythm in that particular part of the total psychic substance which for the time being gives form to a particular human body" (3.191). Voegelin collapses soul and "idea" (i.e., the beings themselves). But this relationship is the very problem that Plato expressed in the proof of the immortality of soul, and more
} 
simultaneously, for the painful experience of this separation is at the same time a reminder of the beloved. The mixture of these two opposites - as if by some daimōnmakes the soul "despair at the strangeness [atopia] of the experience" and it "rages in its perplexity [aporein]" (251d; cf. 240a9-b5). The soul becomes restless, moving night and day. ${ }^{103}$ Rest is only found with the beloved, whose presence re-opens the lover's soul. The lover again "channels himeros" into himself and releases the parts of beauty that had been previously "compacted" inside him, ending his "birth-pangs" (251e). ${ }^{104}$ Its parts compacted inside him, beauty is never entirely absent from the lover, and indeed it is because of the presence of these parts that every human being longs for the whole that it had seen before. That which is held compact in the soul is only a partial gathering together of beauty as logismos was earlier said to do. As Socrates indicated earlier, though, the sensations of beauty need not be gathered through logos. Either way, the compact perception of beauty, being partial and hence incomplete, was not inert and was placed the soul in the disequilibrium that set the soul in motion, in search of peace in the beloved. This compact perception of beauty is the offspring of the soul, as opposed to the bodily offspring that was repudiated. In keeping with the motif of Eleusis, Demeter's seed is ready for harvest: the soul, ceasing from its birth-pangs, "reaps the sweetest

expansively over the course of the myth of the palinode. Soul moves and "pulsates" only insofar as it is separated from the idea, from the Agathon. Nor can the Agathon itself be said to "pulsate," for it is must be eternal and unchanging; only those who are able to perceive it in varying degrees are ecstatic. Voegelin's interpretation has more resonance with the visions of Plotinus and Proclus, and perhaps even the charis of Augustine's God, than with what Plato writes in the Phaedrus. See note 108 below.

${ }^{103}$ Compare the dramatic settings of the Phaedrus and the Symposium. Over the course of the palinode, the sun approaches midday, "when all comes to a halt" (242a), which threatens to overwhelm the soul in the ecstatic experience (see the discussion of the myth of the cicadas in Chapter IV). In the Symposium, the evening conversation descends from the beauty and perfect order described in Socrates' speech into the Bacchic frenzy heralded by Alcibiades, which Socrates seems impervious to as he continues his conversation until everyone else has fallen asleep just before dawn (Smp. 223b-d). Socrates thus fixes his erōs on philosophical conversation night and day.

${ }^{104}$ Empedocles (Emp.) fr. B71, B84 [DK]. 
pleasure" (251e-252a). The cosmic planting of "seeds" into the earth is also found in the soul, and those seeds now grow in the presence of beauty.

The great pleasure that the soul experiences in this birthing, and its offspring as well, will not be "abandoned willingly," and the soul accordingly values its beloved beyond anything else (252a). Only beauty and the erōs for it - not for justice, moderation, or wisdom, all of which have now disappeared from sight - produces the ecstatic change in a mortal by which the old heavy self is transcended. ${ }^{105}$ Because the beloved appears to the lover to be good, the source of peace and relief, the compulsion to return is transformed into willingness. Just as "all soul" was said to never abandon itself, the soul of the lover now includes the beloved as a necessary part of the whole self it once possessed in the presence of true being, thus making the beloved its own. Love is at its core love for oneself as a complete whole, what will in a later time be called the unio mystica. This is also the cause of the selfishness exhibited by Phaedrus. In this case presented here, what the lover refuses to be separated from is pleasure - there is no mention of it being good in itself or "the greatest good fortune" sought at the beginning of the palinode. ${ }^{106}$ The lover will not abandon "the object of longing,"

But he will forget mothers and brothers and all companions, and not place anything on wealth destroyed through neglect, and [neither on] what is customary [or: lawful, nomimoi] and graceful, and is ready to be a slave of all that he scorned. (252a3-6)

Such is the fate of the civil and modest man who once followed custom because of fear for his reputation. Socrates seems to have surreptitiously moved from condemnation to approbation, returning to the same lust that had men crawling on all fours. Socrates, like Lysias, encourages Phaedrus to set aside his fear of reputation and aim his erōs beyond

${ }^{105}$ Benardete 141.

${ }^{106}$ R. 509a6-10. 
the mere opinions of the many. The erōs that leads the lover to forsake the broader community is the erōs that brings the lover into community with this beloved, whom he now "reveres as if a god" and "the sole healer of his greatest troubles" (252b). The capacity for erōs, as love of one's own, to both bring together the community as well as divide is one aspect of the political problem raised by the Phaedrus. ${ }^{107}$ This is the same reason for which Socrates condemned erōs in his first speech, and he echoes those earlier formulations closely, e.g., the lover not allowing the beloved to leave day or night, depriving the beloved of associates, and wanting to reap pleasures endlessly (239d-240a, $240 \mathrm{c}-\mathrm{d})$. Here, though, it is the lover who is enslaved by the beloved; Socrates shows how the lover is drawn outside the bonds and conventions of the community for the sake of the beautiful.

If what is beautiful is good, then the palinode has found "the greatest good fortune" that is bestowed through erōs. The desire of the lover to hold beauty forever is satiated only in the eternity of true beauty, and so in desiring to make the eternal his own, he desires to be without hardship, "whole, simple, unchanging, and happy." This, though, would mean that the lover would have to transcend his body entirely, for mortal life is hardship, and true unchanging beauty is seen only in the superheavenly place (248c, 250d). There is no unio mystica. ${ }^{108}$ We will remain inexperienced in a pleasure that is not preceded by pain, and even the gods never join with the beings. But the mortal lover, in creating a monument to his beloved, wishes to make fixed and unchanging the

\footnotetext{
${ }^{107}$ The ascent of the philosopher against the custom of the city is also described in Plato's Apology as a "stinging" (30e5). In terms of the image here, Socrates is the "gift from the god," whose stinging growth sets the soul into motion.

${ }^{108}$ For Plato, the mystical union would be a not-unexpected but nonetheless erroneous extension of erōs. See Friedländer (1.80-4) for a relevant discussion on the differences between Plato and Plotinus on beauty, and Benardete $(141,146)$ on the irreconcilability of the desires to behold and to have. See note 102 above.
} 
pleasant and immediate appearance of beauty in the boy, and so forgets the being of beauty itself. ${ }^{109}$ This is the reason why Socrates summarizes his "speech" (logos, 252b1) concerning Eros in both human and divine terms:

We mortals call him soaring Eros,

But immortals [call him] Winged Eros [Pterōs], because it is necessary he grow his wings. (252b7-8)

In the first verse, "we mortals" are inclined to make fully divine and worship that which brings us pleasure, and so beautify Eros (cf. 242e1-3). The second verse, supposedly quoted from the followers of blind Homer, is "altogether hubristic" and "not in meter" (252b). The words of the gods escape mortal beautification and art, but are nonetheless true, for Eros is fated to always come to be and never simply be winged, unlike the heavenly Olympians. The two verses together, human and divine, express the perplexing metaxy that is the cause of the lover's pathos.

\section{Searching for God}

A lover will bear erōs, and the painful separation from the beauty he wishes to hold forever as a part of himself, with more or less success. This depends on his original, ancient, nature and which god's train he followed. The followers of Zeus, Socrates tells Phaedrus, are more able to bear "the burden of the winged one" than those of Ares (252c). Erōs is not simply an uplifting experience or seamless ascent to true being, but rather it is dangerously fraught with the same "heaviness" that cast souls to the earth, namely forgetfulness of being (248c, 263d). The lover's intoxication and "reverence" for the beloved boy resulted in the lover memorializing beauty in the boy. Heaviness was found in the lover's bearing of the "compact" bundle of himeros and fragments of beauty;

${ }^{109}$ Lg. 731d-732b. Also see Emp. fr. B2 [DK]. 
rather than searching for true beauty, the lover sought to relieve himself of this heaviness before the particular beloved. The followers of Zeus are able to bear this because their beloved god was that of order, and so understand the role of erös in disclosing that order.

Those who follow Ares, however, follow the god of war and strife. Ares appears at this point in the palinode because of the lover's refusal to be separated from his beloved. The incredible value that the lover places on the beloved and on the pleasure derived from him instills a powerful jealousy. Whenever followers of Ares are "captured by Eros and should believe [themselves] to be done some injustice by the beloved, they are murderous and ready to sacrifice both themselves and the boy" (252c). Despite Socrates' criticism of the jealous love depicted by Lysias and the concealed lover, Ares's love is the very real and recurring consequence of the expectation of unlimited benefit that arises despite the finitude of the particular beloved. Such is the terrible power of erōs that the lover wishes for the beloved to be his alone forever. This self-regard is contrary to Phaedrus's expectation of complete selflessness; when erōs is experienced to this profound extent, the entirety of the lover's being is devoted and subordinated to the bond between him and the beloved. Phaedrus's desire for many potential lovers and benefactors, each satisfying what another cannot, is a manifestation of his superficial understanding of erōs.

The powerful sense of injustice felt by the lover stems from his separation from what he believes to be part of himself, which makes peace and the complete enjoyment of beauty a fleeting and fragile experience. ${ }^{110}$ The subtle theme of war that runs through the

\footnotetext{
${ }^{110}$ Ares's followers traditionally longed and prayed for peace and harmony ([Hom.] Hymn to Ares [Hymn. 8] 15-17). Consider how the three Platonic dialogues directly concerned with beauty are set at the very end of the Peace of Nicias, around 416-415 (see Nails 313 on the dramatic dating of the Greater Hippias), and
} 
Phaedrus now breaks through at the moment of the lover's frustration. When Socrates suggested in the prologue that the Areopagus, the Athenian court which tried homicide cases, particularly those related to adultery, was the likely site of Oreithuia's death, he was alluding to this relationship between $e r \bar{s} s$, strife, and justice. ${ }^{11}$ Justice here takes its bearings from the rigid boundaries that are established around one's own, as if a sacred precinct - one of the professed aims of the urbane speeches. The Ares-like lover is concerned with preserving the present state, and so would be most amenable to the formation of statues - he is susceptible to becoming hard and closed to another, perhaps even higher, beloved. ${ }^{112}$ At the most fundamental level, when the beloved is understood as being itself, this anger and wrath is a hatred of reality itself for refusing to bend to one's desire, such that taking vengeance can only mean repudiating what is and therefore embracing death. There remains the possibility that the utter devotion of an Ares could have disastrous consequences, forgetting once-dear relations and risking the well being of the city for the sake of the beloved. Only the mutual love of an even higher justice could ameliorate this tension in loyalties. ${ }^{113}$ This would be the problem faced by the "lawful king or one who is fit for ruling and warlike," and reiterates his subordination to the "philosopher" and "erotic man" (248d).

The imitation of Ares's war-like and unbending nature by his followers is one example of the imitation performed by all humans. Socrates says that each lives with their beloveds and others in the manner of their god, and will choose his beloved from the

that both the Symposium and Phaedrus allude to the exile of some of Socrates' associates for defiling, on the eve of the Sicilian expedition, what was held sacred by Athens (Hyland 14).

111 Also recall the reference to the gods' war with Typhon and the allusion to the Trojan war (243a-b).

${ }^{112}$ In the Cratylus, Socrates says Ares's name is derived from being "hard and unbending, what is called firm [arraton]" (Cra. 407d).

${ }^{113}$ cf. Smp. 178e-179b; R. 468b-469b. 
beautiful "according to his disposition" (252d). Socrates repeats that the lover will "build and adorn [katakosmein] a statue as if that same one were a god, thus honoring and worshiping him." Knowledge of god, self, and the beloved are concomitant. To this is appended, however, the crucial caveat that the lover be "uncorrupt" and "living his first birth here." That is to say, only in that long-forgotten ancient life of the soul would there be perfect concordance between the lover's idol and his own nature. Socrates implies, however, that in the present, when faced with the impossibility of knowing whether one was living in that "first birth," the lover would misconstrue the god whom he fashions an image of. The lover cannot rely on what he merely believes to be his nature, and this ignorance places great significance on the "search" (zëtēsis) that a lover conducts for his beloved. The search is not merely visual but must take the form of an inquiry, as Socrates himself inquires, into the nature of soul and the different kinds of soul in order to discriminate both the soul of the beloved and one's own soul. Love of oneself and another demands the Delphic quest for self-knowledge (cf. 230a1).

Socrates chooses the followers of Zeus as his paradigm for the search. These look for a Zeus-like soul that is "both a philosopher and leader [hēgemonikos] with respect to its nature" (252e). Such a soul would be most in accordance with Zeus who orders (diakosmein) souls, rather than simply adorns (katakosmein) them; the philosopher will be a leader on account of his true knowledge of soul (cf. 247e5, 252d7). When a Zeuslike soul is found, its god-like nature is only a potentiality, and the lover "will do everything so that he will become such a sort" (252e). That Plato himself undertook such loving labor would not be surprising, particularly given that his phrase, "those of Zeus search for someone Zeus-like," is formulated as the pun Dios dion, or "Dion of Zeus"- 
an allusion to the Dion of Syracuse upon whose urging he attempted to persuade the tyrant Dionysius of Syracuse to a life of philosophy. ${ }^{114}$ In this most intimate moment between lover and beloved, the life of philosophy that they erotically pursue becomes the heart of political reform. The discovery and seduction of kindred souls will become critical to the political concerns of the Phaedrus that come to the fore in the discussion of rhetoric.

The joining of Zeus-kin is depicted, in the arithmetic middle of the dialogue, as the culmination of a search for god (252e5-253b1). A lover begins searching by learning from others and his own efforts, and "by following the scent from within himself to the discovery of the nature of his god, he finds [the god] through the compulsion [anangkesthai] to look intensely upon the god." This inward examination is a sharp departure from the ways of ancient oracles and seers, who would look to omens in the world around them. Now, the compulsion of erōs to find that which would complete and heal oneself is the very way by which god is found; ${ }^{115}$ god is found in how the lover creates his monument and whether it is a fitting reminder, for "he touches him [god] through memory." As seen earlier, the lover compacted desire and parts of beauty within himself, and so contained a god that would bear him aloft. Being thus "enthused" through recollection, he shares in the god by adopting his practices and ways, and then attempts to realize his experience of god in the world outside himself. Since the lover "holds the beloved to be the cause for [his enthusiasm], he is fond of him still more."

\footnotetext{
${ }^{114} \mathrm{Pl}$. Ep. 316c-317d, 7.327b-329b, 8.355a. On the pun, see Wilamowitz 1.537, followed by numerous others (e.g., Hackforth 99n2; Nussbaum 229; Voegelin 3.72). Yunis doubts the allusion, arguing that this advertisement of Plato's "private life would reek of melodrama and disrupt the elevated tone that is an essential aspect of [Socrates'] message" (Yunis 2011 156-7). This overlooks, however, both Socrates' and Plato's playfulness in the palinode, as well as how the allusion emphasizes that philosophy is realized in human relationships which seriously take the other as a monument and hence way for the recollection of the truth.

${ }^{115}$ Yunis $2011157 \mathrm{n} 252 \mathrm{e} 4-253 \mathrm{a} 2$.
} 
Through this search, the beloved is seen as the cause of the vision of god, but is not the vision itself nor god. The beloved therefore becomes pleasing to the lover not as a mere reflection of his desires, but as a reflection of the god he once saw.

Although the discovery of Zeus is only one possibility, it seems that it is exclusively those who find him, that is, those who are philosophers by nature, who are able to make the beloved in the image of god: "if it is from Zeus that they draw, like Bacchants they pour the draught upon the soul of the beloved, making him as like [homoios] to their own god as they are able." The goodness of erōs is first seen in how the search opens the lover to the divine. It is also seen in how his erōs, drawing from a font, overflows the limits of his soul, and so inspires the fond wish to bring what is beloved into harmony with god. Insofar as the two participate in the nature of the same god, the interests of both the beloved and the lover will coincide. But the lover's affection for the beloved comes after he has discovered god, and therefore after he has determined what is best and most worthy of worship. Only if he had seen the truth in its entirety, and had not forgotten it, would he be able to do his beloved an unmitigated good deed. ${ }^{116}$ The overflowing Bacchic frenzy is only rehabilitated under the authority of Zeus and his philosophers. Socrates thus implies that his own earlier Bacchic frenzy was drawn from Zeus. At the same time, by restricting the beneficence of that frenzy to philosophers, Socrates covertly criticizes the poets, who were said to glorify and memorialize the ancients for the sake of educating the young. Although well-intentioned, the poets are incapable of truly making their beloveds in the image of god unless they become philosophic. This is particularly startling, given that it is the poets who have depicted the gods so beautifully, while it is Socrates who has denied them bodies and

\footnotetext{
${ }^{116}$ Benardete describes this as "a forced fitting of the beloved into a previously fashioned image" (154).
} 
subordinated them to the true beings. Within the present myth, then, to search for god is only to search for a guide to the highest and "most blessed mysteries" - this search for god, compelled by erōs, makes no mention of beauty itself. The erotic desire vested in the form of a god has concealed the true source of inspiration once again.

As for those who followed other gods in their first life, they will behave similarly, and so Socrates repeats the search for god and the formation of the beloved. He only mentions by name Hera, whose followers seek royalty, and Apollo, to whom no attributes are assigned (253b). Even those who now follow Apollo, the priests and prophetess at Delphi, must search for their god in themselves, despite the ancients' scorn for the merely human "search" (244c6). Socrates covertly alludes to the inscription at the temple of Delphi, "know thyself," and gives it a novel interpretation. It is not simply a warning that petitioners will not understand the words of the god unless they know themselves, i.e., that they should enter the god's temple complete and at the end of their search, but that the temple is the site at which self-knowing begins. Self-knowledge is the mission of the god. ${ }^{117}$

This search for god and self-knowledge is by no means the understanding of love that the beloved holds. Socrates says that the beloved must still be "persuaded" and "disciplined" in the practices and "form" (idea) of the god (253b5-8). ${ }^{118}$ That the beloved must be seduced into the search, even though he was perceived to have a suitable nature, means that he was not only ignorant of himself, but ignorant of his need for selfknowledge. This is the problem that Phaedrus presents. Only when the beloved is

\footnotetext{
${ }^{117}$ Ap. 23b, 30d-e.

${ }^{118}$ Gods and the beings themselves were clearly distinguished earlier in the palinode, and the present use of idea with reference to the gods is not inconsistent with this. Rather, it is an extension of the common usage of form, which partakes in "the ideas." All that is perceptible, whether by sight or intellect, must have form, but there is no indication that such forms are the beings in themselves.
} 
persuaded to a life of philosophic self-inquiry will the lover be able to find the god. Only then will the "eagerness of those who truly love, acting in the manner I say," Socrates tells Phaedrus, become "beautiful" (or: noble, kalos) and bring them happiness (253c). Rather than the dangerously self-obsessed erōs depicted by Lysias and the concealed lover, this erōs produces an affectionate exchange from one friend (philos) to another, free of jealousy. The discussion of Ares-like lovers, however, showed jealousy to be an ever-present danger in love. Perhaps only the lover who seeks Zeus can attain true love, if he can catch the beloved in the right way.

\section{Capturing the Beloved}

Only now, after the development of a cosmology and psychology, all of which Socrates now explicitly called a "myth," can the nature of persuasion be discussed, as it depends on the nature of the beings and how the soul experiences them (253c). Persuasion is seduction, the making of a lover from a beloved or non-lover. Only in this turning around of the beloved is the greatest good fortune of erōs embodied in the characteristic activity of the lover. Socrates returns now to the original image of the soul, which divided "each soul by three," that is, as a charioteer with two horses. At the beginning of the myth, Socrates focused on the unity of this "form," its "combined power" to which wings were attached (246a3, a6-7, 251b6-7). The presence of wings is coextensive with the unity of form, as the ever-winged gods are harmonized with their own work, one another, and true being. Now Socrates turns his attention to the disunity within the soul and the human experience of interior struggle for unity. 
The struggle occurs between the charioteer and his two horses. Since the competence of the charioteer is for the moment held constant (but cf. 248b), Socrates will only describe how the struggle originates from the horses' opposing "two forms" (253c). The good horse is the "nobler" or "more beautiful," although the use of the comparative indicates that it is not simply or altogether good. This is also the first indication that the bad horse should not be considered simply or altogether bad, the reasons for which will soon be made clear. The goodness and relative beauty of the first horse is found in the first place in its shape. It is "straight [or: correct] in form" (to eidos orthos) and "welljointed," it nobly "carries the neck high," is white in color, and has black eyes (253d). As for its character, the horse is "a lover of honor [erastēs timēs] with both moderation and shame, a companion of true glory [or: reputation, doxa], needs no whip, [and] is driven by command and speech [logos] alone" (253d-e). Unlike the middle part of the soul in the Republic, he does not possess the anger and steadfastness characteristic of thumos or spiritedness, and indeed there is no mention of thumos in the palinode. ${ }^{119}$ At first glance, the horse is well-formed in both its look and actions, and its own parts function well with reference to the whole and the whole responding well to the charioteer. As just suggested, though, the white horse has limitations, some of which are indicated by its attributes.

The white horse is erotically drawn towards honor, that is, towards the praise of others. That erōs could be moderate and without hubris is a new development, but in

\footnotetext{
${ }^{119}$ See $R .375 \mathrm{c}, \mathrm{e}, 410 \mathrm{~d}$, and esp. 440a5. There, Socrates also attributes to thumos the love of honor, which in the Phaedrus is possessed by the white horse (cf. $R$. 545a, Phdr. 253d-e). The tripartite division of the soul in the Republic does not correspond to its division in the Phaedrus. The absence of thumos in the Phaedrus is related to its ostensibly apolitical character, and particularly to Phaedrus's character, which lacks any real civic attachment (see the discussion in Chapter II and the discussion of Isocrates in Chapter V).
} 
keeping with the love of those who are "noble and gentle" (243c-d). The fact that it is the good horse that is attracted to doxa is a rehabilitation of doxa, opinion, which had been attacked for inhibiting erōs. This rehabilitation is mixed, however, for the horse does not necessarily drive himself to what is best. He follows "true reputation," or more literally, "that which truly seems best" (alethine doxa). What seems to be best can therefore be true, even though it is plain that an opinion can be true or correct even though it is not held with knowledge. ${ }^{120}$ For example, Phaedrus is not wrong to believe that the moderation of his bodily desires is healthy. The same consideration should be given to the opinion that reproved the lover's memorializing and deifying of the beloved (251a). It seems that the white horse can remain correct in its opinion, however, only through the words of the charioteer - words which would not be needed unless there were some risk or precedent of the white horse straying from the correct path. The fact that the word logos and its cognate logismos only appeared after the mortal soul had fallen from the superheavenly place suggests that logos is only of use when the mind cannot immediately perceive the truth. Such pure thought is the power of the gods alone, to whom Socrates never attributes the capacity for speech. ${ }^{121}$ The white horse remains outside of the intellect and is sub-rational; the charioteer may speak orders to the horse, but he does not reason with it. Instead of physical violence, the charioteer may appeal to the horse's desire for true reputation and use shame to direct him.

The bad horse is the opposite of the white horse in every way. He is "crooked [or: hard, skolios]" and misshapen, with "manifold" parts that look as if they "have been heaped together at random [eikos]," "flat-nosed," black in color, and has grey bloodshot

\footnotetext{
${ }^{120}$ Pl. Men. 97a-98a; R. 413a-c; Tht. 200e-201c.

${ }^{121}$ Hyland 76-7.
} 
eyes (253e). He is "a companion of hubris and boastfulness," disobedient, "hardly yielding to whip and goad together," and deaf. The horse's physical appearance is one of disorder, and so seems to be the source of Socrates' wonder that he may be "more complex than Typhon" (230a). This disorder and formlessness is repeated in his behavior, acting with the excess and hubris which, for Lysias and Socrates' concealed lover, characterized erōs as a whole. The randomness (eikos) of the horse's appearance is as if he was formed for manifold purposes, just as he is excessively attracted to the immediate objects of desire; it is the black horse that drags the soul "on all fours" towards the pleasures found in phantoms and images of true beauty (250e-a). The human attraction to the "likely" (eikos), which Lysias played upon with no little skill, originates from the black horse's desire for beauty in its multitude of manifestations. The hubris of the black horse is compounded by the poor eyesight by which it might otherwise distinguish image and truth, as well as deafness to the commands of its charioteer. Its black color indicates its opacity to the colorlessness of form and true being, and indeed that it is full of that which obscures.

The darkness of the horse is the link between erōs, desire, and the need for the search. Although the excessive desire of the black horse entails the confusion of images and monuments with truth, it is precisely that excess which inspires the search for one's true nature. As noted earlier, it is through the compulsion of erōs that the soul discovers god and his nature, and that compulsion will act through the irresistible pull of the black horse. Socrates does not therefore simply denigrate the black horse as the lowest part of the soul, but portrays it as the part first aroused in the recollection of true being. The blackness of the horse, its non-being, is what sets the soul in motion towards the 
beautiful, and it is his role in capturing the beloved that is of principal interest. This powerful desire, however, must be guided and disciplined, and because of the horse's hubris and poor senses, it is obstinate. Having no other means to reach the black horse, the charioteer must punish and restrain it violently.

The internal struggle for mastery that Socrates described in his first speech, and implied could only be achieved by the non-lover, is now integrated into an account of erōs that requires that the lover himself attain self-mastery. In fact, the two horses form a team of opposites which happen to share the very same properties as the two forms of soul found in that earlier speech ( $237 \mathrm{~d}$ ff.). One side listens to speech and is moved by honor and opinion, the other is "without logos" and moved by an insatiable hubris (238a1). Socrates now relieves the tension of that dualism by harnessing the two parts to the intellect, which, having been freed from its subordination to desire and "interest" (oikeios) in Lysias' speech, and to opinion in Socrates' first speech, is able to perceive what really is. The nature of the soul has therefore been unfolded over the course of the three speeches of the Phaedrus, and the form of each speech has changed accordingly. The first two speeches appealed to Phaedrus's bodily moderation and self-interest, although it was only Socrates' speech that was able to coherently distinguish two parts of the soul. In that speech, Phaedrus found himself reflected in the rule of opinion over the desire for bodily pleasure. Phaedrus, it could be said, is the white horse. In the previous chapter, this dualism within the soul was shown to be insufficient, unable to account for the speaker's interest in the boy without contradicting his professed moderation. Now Phaedrus will be shown how those two opposites can coexist within the same soul, ruled by the intellect that alone perceives the true object of erōs. 
When the charioteer sees the eyes of his beloved, "all of the soul is warmed by perception" and "filled with tickling [by the shoots of the wings] and pricks of longing" (253e-254a). This "longing" is the same longing for true being that is generated after forgetfulness has filled and weighed down the soul. But if this longing is directed only at the earthly manifestations of beauty, it too can become a cause of forgetfulness. Life here, insofar as it entails perception, is a life of forgetfulness - forgetting oneself in the very objects that can remind us of the original cause of our longing. Such is the nature of beauty $(245 \mathrm{c}-\mathrm{d})$.

Having been filled, the white horse "is forced [biazesthai] by shame" to restrain himself from leaping on the beloved, while the black horse, "leaping with force [bias], is carried [pheresthai]" forward (254a). Again, Socrates' use of the passive pheresthai is significant, as it signals the soul being placed in subjection to the object of desire, as it once was when it gazed upon the beings (see $247 \mathrm{~d} 5,248 \mathrm{a} 8,250 \mathrm{c5}$, e2; cf. the active voice at 252c4). While the soul was perfectly passive before the beings, the black horse here becomes active when it feels the pull of erotic inspiration. The force with which he does this is irresistible and experienced as necessity (anangkē) by the white horse and charioteer. The black horse, unable to perceive anything else, is led to the beloved for the sake of sexual pleasure; this is the principal way for the embodied soul to alleviate its painful separation. The black horse wishes to propose things that are, for the white horse and charioteer, "terrible [deinos] and improper [lit. outside convention, para-nomos]," and they attempt to resist (254b). After much agitation by the black horse, they finally succumb, and "the two follow his lead" and "agree [homolegein] to obey his commands." 
The drama that Socrates is now narrating reenacts the drama that he and Phaedrus had performed earlier. There, Socrates had placed Phaedrus in the role of the black horse. Socrates followed Phaedrus's lead after Lysias' speech, but attempted to resist the younger man's desire for a new speech once he was propositioned with things outside convention - namely the statues dedicated by the Cyspelids and law-breaking archons (235d4-237a6). The dramatic action between the two men was of the same form as the struggle that is now taking place within the soul. This parallel between deed and speech should not be construed as either a fabrication or fantastic prophetic insight on Socrates' part, but rather a consequence of the depth of Socrates' insight into the ways of erōs (see 257a7-8). That is, Socrates has imitated the essential motions of the soul in both speech and deed for the benefit of Phaedrus. Indeed, Socrates has at different moments assumed each form found in the soul. At the beginning of the interlude, he assumed the form of the white horse and charioteer being dragged along by the black horse, but when Phaedrus resisted his analysis of Lysias' speech, he took the form of the black horse and promised the pleasures of a new speech. By doing so, Socrates was able to show Phaedrus how his moderation was an instrument for attaining the pleasures of speech, and that the hubris of desire lay below the surface; he could not be the white horse simply. Socrates incited and so revealed to Phaedrus the importance of his own black horse.

Likewise, when the charioteer is brought before the beloved and looks into his eyes, their "flashing" like lightning takes his memory to "the nature of the beautiful" which he once saw outside the heavens (254b). ${ }^{122}$ Nature is not simply what grows or is found outside of human making, but the very perfection or pattern to which that growth

\footnotetext{
122 "To flash," astraptein, is a cognate of astrapton, "lightning," and is related to astron, "star." Lightning is the power of Zeus that unites heaven and earth.
} 
tends. The nature of the soul that Socrates sought at the beginning of the palinode is discovered in its relation to the nature of the perfect beauty that inspires it $(245 \mathrm{c})$. To this point, the desire for beauty has been at the expense of the conventions or laws, opinions, and associations which restrain a lover (e.g., 252a). Yet now, rather than indulge his unconventional desire, he restrains it for the sake of what he truly desires, what he desires by nature. Socrates thus subtly indicates that what is conventional is not necessarily in diametric opposition to what is natural. That is to say, the conventional can be brought into harmony with, perhaps even support, what is natural - the lover was earlier said to "make" his beloved in the image of god, i.e., bring him into concordance with his natural potential (252e1-5). Transcendence and the fulfillment of nature need not be at the expense of the city. Despite the overpowering effect that the beloved has on the lover, the vision of the nature of beauty is accompanied by moderation: the charioteer "sees it [beauty] again standing with moderation [sōphrosunē] on a holy pedestal" (254b).

That this erotic and mad pursuit leads to a vision of moderation is surprising, for the earlier passage concerning enthusiasm was silent on this point. Phaedrus will no doubt feel vindicated by its appearance here, but also puzzled that he can become truly moderate only through erōs. This is far different from the form of moderation he was attracted to in the previous two speeches, which repressed desires for the sake of satisfying them in the future. Instead, it is the subordination of all earthly desires to the end of erōs, which is the intellection of the beings themselves. Phaedrus's moderation, because it originates in the maximization of pleasures, actively precludes the transcendental erotic pursuit that partakes in true moderation. Moderation is the manner in which the true beings are seen in themselves, for that beauty which is pure and 
unmixed with any other being is distinct in itself, which is to say it is in perfect accordance with itself and never abandons itself; unlike soul, it is not ecstatic but at rest. The lover could not therefore experience true beauty with hubris, for he would always miss it; only through restraint will erōs be able to distinguish an image from what is truly desired. This is the power of Socrates' daimonion, which by restraining him holds him to the divine way, and as such could be said to be erōs (it is not a god but "something divine" [242d9]). ${ }^{123}$ Consequently, the hubristic desire of the black horse is only vindicated insofar as this great desire for unending pleasure in union with the beloved points to a being that is not limited by time or space and so is eternal and unchanging. As Socrates said earlier, the erotic search for nature is inspired by the beauty of the beloved, not the beloved himself. Lysias was therefore correct in saying that the lover's search for a higher object of desire will disappoint many a beloved. ${ }^{124}$

Moderation now possesses the entire soul. The charioteer, in fear and reverence, "falls on his back" before beauty, and "is compelled" (anangkazein) to violently pull both horses back onto their haunches $(254 \mathrm{~b}-\mathrm{c})$. True beauty and moderation seem to push the lover back, placing him in the passive state that his soul experienced so long ago, when the cosmic period carried the chariot on the back of heaven (247c). The soul is nourished and becomes most god-like in its motion on account of its moderation. ${ }^{125}$ This moment of harmony between the soul and its true object of desire is fleeting, as the white horse trembles and sweats with shame and anxiety, and the black horse impatiently struggles to continue its pursuit of the beautiful boy. The chariot thus reenacts in the present its ancient cosmic struggle to maintain its view of the superheavenly place, and is quickly

\footnotetext{
${ }^{123}$ Following the suggestion of Friedländer $(1.44,53)$.

${ }^{124}$ Alcibiades' shame at being spurned and charge that Socrates is hubristic is a case in point (Smp. 221 e).

${ }^{125}$ Pl. Charmides 166c, e, 168a, 169d-170a. See Klein 25.
} 
cast back down to earth. The fall of the soul and its vision of truth are coincident; the moment of the soul's complete satisfaction and rest is at once the moment the soul begins its descent to earth, its motion, and its longing.

In this struggle, the black horse reviles both the white horse and charioteer "for deserting their post [taxis] and agreement [homologia] in fearfulness and cowardice [or: unmanliness, anandreia]" (254c-d). The black horse resorts to military language in Areslike anger aroused by separation from the beloved. This "post" or "station" (taxis), the pursuit of sexual pleasure, is defended in ignorance, however, of both true being and the nature of the soul. The gods who perfectly maintain their own stations (taxeis) live in harmony with truth, and earthly resoluteness proves a poor imitation of the gods' knowing self-possession and steadfastness. Both the charioteer and white horse had only agreed to pursue the beloved, an image of beauty, in ignorance or forgetfulness of true beauty. Their oath-breaking appears to be forgiven by the realization that the beloved is not, in fact, simply beautiful, but only a reminder of beauty. Yet the desire of the black horse, apparently misplaced, was a necessary prerequisite to recollecting true beauty in the beloved. No other approach to true beauty is possible but by way of its images; because the soul must commit itself to successive perceptions of beauty, it is deceived on its way to truth. The ascent of the souls was not direct, but by turns (247a5). Indeed, the white horse and charioteer will, in the next pursuit of the beloved, deliberately lie to the black horse and "pretend to forget" their promise (254d).

In this second sortie, the black horse is told that he must defer union with the beloved boy to another time (254d). The soul cannot grasp the object of desire, in its completeness, in the present, but the black horse is deceived into believing that his 
longing to be with the beloved forever can be satisfied in the future. The black horse is deceived by this promise for the future just as the beloved was in Socrates' first speech (241a-b). The myth of the superheavenly place revealed that what the short-sighted black horse expects for the future stands outside time altogether; it is upon this expectation that Socrates distinguished the moderns from the ancients, an ignorant neediness from the self-sufficient completeness of the gods. In his eagerness, the black horse "reminds" the white horse and the charioteer of their previous commitment to pursue the beloved boy, for the others would simply forget the boy in their enjoyment of their vision of true beauty. ${ }^{126}$ Since the theme of the passage is the moderation of the black horse, it is tempting to see the horse's continued struggles as mere distraction or nuisance in this process. But Socrates' attribution to the black horse the power "to remind" (anamimnēskein) reverses his earlier usage of reminders: here, it is a reminder of earthly things, not the beings themselves. This seems to be a blatant contradiction of Socrates' earlier account of recollection - would not the black horse's "reminding" constitute a forgetting of being? This very question, though, mistakes the lover's enthusiasm, depicted earlier in the pseudo-physiological account, as solely sexual. Rather, that passage was concerned with any beauty that induces "reverence" and "fear" - as indeed the charioteer now reveres his recollection of beauty $(251 \mathrm{a}, 254 \mathrm{~b} 8)$. The charioteer is in danger of making a monument of his memories. The danger of memorializing beauty therefore extends beyond bodily "images," and warns against the impossible fixation on

\footnotetext{
${ }^{126}$ This is the concern expressed by Gregory Vlastos, that the beloved is not loved for his own sake, but only as a mere stepping stone to the beings - a concern no doubt amplified by his opinion that "the ideas" are merely "place-holders for the predicates 'useful' and 'beautiful" (1981 26). Perhaps because he believes himself to be following Aristotle's account of friendship, Vlastos fails to notice that he is here allied with the black horse (and Alcibiades - see note 124, above). In recognizing this, he would see how Socrates acknowledges that the black horse, by reminding the soul of its embodiment, is crucial for disinterring the soul from fixating on the beings in an impossible manner.
} 
what seems to be true beauty in itself. When Socrates says that the black horse reminds the soul, he is reminding Phaedrus that the soul can only know true being through the perception of its manifold and mixed manifestations, i.e., through the body (cf. 249b6c4). ${ }^{127}$ Expressed in the terms of the myth, the human soul must ascend and descend. The lingering earthly desire expressed by the black horse is crucial for the soul's "correct" use of reminders (249c-d). Furthermore, since recollection proceeds through reasoning (logismos), and thus the use of words or speeches (logoi), it is clear that even the logos that is the way for recovering true being is liable to induce forgetfulness. This is the difference between "what is said" by being and "what we now say is" (247d, 249b). This was also the same point that Socrates made with his first speech, when the apparently clear use of definition ("bounding") obscured the object in question, namely erōs. Now the charioteer recognizes the need to break his verbal agreement with the black horse.

The black horse is brought to heel only after the soul has been drawn to the beloved boy for a second time, and the charioteer again experiences ("suffers") the recollection of beauty and consequent fall. This time the charioteer is unsparing in his violent restraint of the black horse, wrestling with it until the bit has spattered the horse's mouth with blood (254e). Since the horse can only understand pain, many such experiences will be required to train the horse to feel fear whenever it approaches the beloved and "ceases from its hubris." The experience of erōs is, for the entire soul, "toilsome" and marked by "sufferings" as it struggles with itself. The capture of the

\footnotetext{
${ }^{127}$ Compare Socrates' remark that he must run away from Parmenides as well as Heraclitus (Tht. 179d$181 \mathrm{~b}$ ), or Parmenides' refutation of both the hypothesis that "the many are" as well as that "the one is" (Prm. 136a-c), or the Eleatic Stranger's risking of "parricide" in refuting Parmenides' thesis that only the one is (Sph. 241d).
} 
beloved is thus preceded by the lover's difficult struggle to become moderate, which depends on perceiving the true beauty that is the original source of inspiration. Socrates thus seems to elide the beloved in question: is it the beautiful boy or beauty itself? The attainment of one depends on the attainment of the other. As Socrates goes on to explain, it is only when each soul becomes open and transparent to the truth, dedicated to its realization, that the beloved will be "captured" and the two lovers bound to one another. The form of the struggle within one soul is thus closely related to the form of the pursuit between two souls.

With his black horse tamed, the lover again follows the beloved in reverence and makes a monument of him, before which he may sacrifice (251a). Unlike the "therapy" of the concealed lover, the lover gives the beloved services or therapy (therapeuein) as if he were "equal to a god" (255a). Since the lover is not "pretending to love but has truly experienced this $[e r o ̄ s], "$ the beloved is naturally a friend to him. Despite any "prejudice" the beloved may hold towards lovers on account of the opinions of others, such as Lysias, he will eventually allow the lover into his company (255a-b). This, Socrates says, is a "necessity" or "what is due or fitting" (chreōn), not simply because the lover has given services that should be repaid, but because "it is a decree of fate that never shall bad be friend to bad nor good not be friend to good" (255b). Socrates' argument here of course takes for granted that the lover is good, not merely in his intentions, but actually good in his actions and benefiting the beloved. Moreover, it is also assumed that either the beloved recognizes that he is being benefited, or that even the true lover resorts to flattery. Socrates shows to Phaedrus only the best case possible, not the undoubtedly 
long and difficult search for what is good or bad and suitable or unsuitable for one's nature.

Regardless, the good will that the lover provides with his "speech and company" exceeds the "friendship" (philia) of all of the beloved's relations, and so "strikes out [ekplettein] the beloved" (255b). The beloved is led by this to turn towards the lover and spend more time with him. The experience of enthusiasm is awakened as himeros and beauty flow through the beloved to the lover. Since the lover is in the presence of his beautiful beloved, his soul remains open, and the "stream" (pēgē) of beauty pouring into him "overflows" and returns to its source - just as the font (pēgẽ) of motion moved itself (255c, cf. 245c10). The stream that the lover pours over the beloved is thus drawn from the beloved himself, which Socrates depicts as the draught Zeus poured over his beloved Ganymede, whom Zeus had stolen away from his family and made immortal wine-bearer to the gods. Ganymede's tale of divinization through love is the happy counterpart to Oreithuia's. ${ }^{128}$ In the context of Socrates' narrative, Ganymede becomes divine through the stream of beauty which his lover sends "back into the beautiful" just as "a sound or some wind echoes off a hard surface and is carried [pheresthai] back whence it had been set in motion." ${ }^{\prime 29}$ The lover does not impregnate the soul of the beloved or fashion him in his own image, but inspires the beloved to bring forth his own "compaction" of beauty (cf. 251e). ${ }^{130}$ The inspired beloved begins growing wings, for he too "is in love [eraein]"

\footnotetext{
${ }^{128}$ Hom. Il. 5.265ff.; [Hom.] Hymn to Aphrodite (Hymn. 5) 202-17.

129 "Wind" is pneuma, also meaning breath or spirit or life force, which in archaic usage was a synonym for psuche, meaning breath or soul. The hardness from which the soul rebounds may signify the body; souls move other souls through their bodies. Or in more general terms, soul moves itself and so returns to itself by way of its opposite, body. The embodiment of soul is necessary to its self-motion.

${ }^{130}$ Socrates says he is not the source of logoi in his interlocutor, but instead assists them in becoming "pregnant" and then "giving birth" to what is inside them (Tht. 148e-151d). This is in keeping with the account of the palinode that reasoning and learning are "recollection." Socrates' refutation of his
} 
and becomes a lover. This is the beginning of a mutual love that was occluded in the previous speeches' duality of lover and beloved.

The former beloved does not yet perceive the beings, but is perplexed (aporein), and now undergoes the same experience as did the lover who was separated from the source of his enthusiasm $(255 \mathrm{~d} 3,251 \mathrm{~d} 8),{ }^{131}$ The perplexity of the beloved is the experience of ignorance: the beloved was not attracted to the lover, but is now turned towards him and cannot account for this (255d). Moreover, the erōs of the lover, purified by the glimpsing of moderation itself, would be unrecognizable to the beloved as the vulgar erōs criticized by Lysias and the concealed lover. The beloved has nonetheless attained a sort of knowledge, that it is not precisely the lover himself that he loves or that it is not precisely himself that the lover loves. This perplexity presents an opportunity for the inculcation of philosophy that will search out the divine through its images. In fact, it is only by becoming a lover, being open to the possibility of understanding the true nature of things, that one can attain self-knowledge, for there was no perplexity in the soul of the beloved until he turned to the object of his love. This is why it is his own beauty that is reflected back, "as if in a mirror," and inspires him. But the beloved does not recognize this, which is not surprising given the difficulty of understanding how the services and good will of the lover constitute a reflection of the beloved. The earlier experience of the enthused lover can clarify this: the lover longed to be with his beloved because he did not wish to be separated from what he saw as his own, and the apparent wholeness he had

interlocutors is not, then, simply an eristic victory, but a reflection back to the interlocutor the selfcontradiction in their reasoning.

${ }^{131}$ Consider how Plato puns on aporein, "to be at a loss," with aporrein, "to fall off" (i.e., wings): "let us grasp the cause of the wing falling, why it falls from [apporein] soul" (246d3-5). This implies a relation between the two experiences. Both, it has been noted, are coincident with separation from being, which is to say that erös is at once the perception and lack of being. See also Smp. 192c-d. 
thus achieved. The beloved sees, then, in the services of the lover, a good from which he himself would not be separated, and which the lover indicates is due to him; it is, after all, his own desires that are aroused by the lover's deeds. His inability to recognize himself in his attraction to the lover is therefore a profound ignorance of himself, but his erōs will become a guide to self-knowledge. Plato provided an example of this earlier, when Phaedrus proved ignorant of what it was, precisely, that he found pleasing in Lysias' speech, as well as of what would constitute a good and noble speech.

The beloved, having become a lover, is now also afflicted by the pain and pleasure of separation and reunion. Each lover is "longed and longed for" (255d). But as a consequence of the beloved's perplexity, the love that he holds is "a return of erōs [anterōta], a phantom [eidōlon] of erōs; but he calls it and supposes it not to be erōs but friendship [philia]. He desires [epithumein] in a similar way to that man [the lover], but more feebly" (255d-e). This passage is remarkable in that it locates friendship (or friendly affection) in the erotic experience, as what might be called a derivative of erōs. On the one hand, it is obvious that lovers may also be friends with one another. Yet on the other, Lysias, and indeed common Greek usage, kept erōs and philia starkly separate, for fear of attributing erotic desires to the affection one feels for, say, mother or father $(233 \mathrm{c}-\mathrm{d})$. Less sensational, but more interesting, is the coincidence here of friendship with epithumia, a desire for pleasure in bodies, which were themselves shown to be images, memorials, or phantoms of beauty. Friendship, not erōs understood as bodily desire, is the proper "erotic" relation between these two humans, indeed it is the proper relation to earthly things. A phantom of beauty is properly approached by a phantom of true erös. The restoration of friendship thus restores the friendship felt for friends and 
family that was lost in the ecstasy of erōs (239d-240a, 252a, 255b). This does not mean that true love and the experience of true beauty cannot be found in the lovers' relationship - quite the contrary in fact. The beings can be found in their friendship as well. Socrates' defense of Eros does not entail the repudiation of community, but points to the community that in which the truly good can be embodied and in which a form of erōs appropriate to it may be inspired. Indeed, without the defense of friendship, the other side of erōs is left unchecked. Its forgetful heaviness, as opposed to its recollecting lightness, lends lovers to selfish greed, jealousy, and ultimately strife (the soul must "use reminders rightly") (cf. 248c7, 256b4). Erōs therefore forms a community at the risk of forgetting being, that is, at the risk of forgetting what is necessary for loving well and benefiting that community. A true lover, a true friend, must remain in the tension of the metaxy, not because he would otherwise forget the heavenly for the sake of the earthly or vice-versa, but because the heavenly can only be perceived through the earthly and the earthly can become the best possible only in light of the heavenly. In so opening themselves to this tension, the lovers become moderate in their relationship.

Still, the temptations of sexual desire, which "the licentious horse whispers to the charioteer," may prove too powerful for the lover to resist, now that the beloved is turned favorably towards him. Or, should the lover prove immoderate or deceptive in his erōs, he may take advantage of the beloved's lack of understanding. The beloved, "being swollen [with desire] and perplexed," would readily "lie with" his friend, "embrace" him, and "give him favors" - charisesthai, the sexual favors of Lysias, rather than the therapeuein of the true lover (cf. 255a, 255e-256a). His white horse and charioteer, however, resist with both "shame and speech [logos]," awakened by the experience of 
perplexity and dim awareness that it is not the body of the lover which is desired. The beloved, then, must learn to restrain his black horse and moderate his soul's desire for what is false, just as the lover did. ${ }^{132}$ The lover, through his restrained counsel, will shape his beloved in the pattern of moderation he once glimpsed. ${ }^{133}$

Should these friends be able to resist their sexual desires, with "the better [parts] of the mind victorious" in each soul, they will be led "into a well-ordered [tattein] way of life and philosophy," and achieve that greatest good which Socrates promised. He tells Phaedrus that "neither divine mania nor human moderation is able to furnish a greater good for human beings" (256b). This is not simply the mythical growth of wings and ascent - Socrates reiterates that that occurs only after death - but "leading a blessed and harmonious [homonoêtikos] life here" (256a-b). To follow in the orderly train of the gods is a way of life in the here and now, the forming of a manifold soul into one. How, precisely, that way of life will be conducted - presumably by following the logismos that is recollection - is not explained. Instead, Socrates shows a life of successive mirroring, the beloved through the lover and vice-versa, each glimpsing in the other the true beings, their god, which make them virtuous and truly beneficial. ${ }^{134}$ The lover will come to be of the same mind (homonoia) as the beloved through the pursuit of true being, not by mere

\footnotetext{
${ }^{132}$ Cf. Smp. 218c-219d.

${ }^{133}$ The prohibitory power of the daimonion extends beyond Socrates' own actions to his counsel and the actions of his associates as well. See Theages (Thg.) 128b, d, and esp. 129e.

${ }^{134}$ This no doubt informed Aristotle's conception of agonistic friendship, perfected in the case of philosophic friendship (EN. $1156 \mathrm{~b} 6 \mathrm{ff} ., 1169 \mathrm{~b} 30-1170 \mathrm{a} 5,1172 \mathrm{a}$ ). Compare esp. 1156b6-7 (complete friendship is between good men, who "wish good for one another insofar as they are good") to Vlastos's formulation of Aristotle's "standard" ("to love a person we must wish for that person's good for that person's sake, not ours" [Vlastos 19816$]$ ), which is ostensibly based on 1166a2-5, but has more resemblance to the charitable affection of a mother who assumes her child to be wholly good - as Aristotle says on the very next line. The Aristotelian "standard" by which Vlastos would measure Plato is in fact not a standard at all for Aristotle, and more likely derives from the Kantian dictum to see others not as means but as ends in themselves. A similar error is found in Bentley's critique of the urbane speeches (238).
} 
agreement (homologia). ${ }^{135}$ For a man like Phaedrus, accustomed to being the non-lover or beloved, only love for some transcendent being will carry him outside himself and his presumption of knowledge. The beloved non-lover in its highest form was shown to be the beings themselves, pure and unmoving in their self-sufficiency. Lysias had therefore already perceived, dimly, the ultimate superiority of what is loved to the lover, on the simple observation that it is the beloved who sets in motion the lover. ${ }^{136}$

The truly beneficent friendship is safely guarded only by a life dedicated to wisdom. If friends slip to a love of honor characteristic of the white horse - that is, if their charioteers should resign control to even the good horse - they will succumb to their bodily desires. Their black horses will "take their souls unguarded [to] the choice which is said by the many to be most blessed" (256c). This derision for the many is particularly powerful, not in that they should desire sexual pleasure, but that they should honor it secretly while deploring it publicly (253a). This is the hypocrisy and confusion that Lysias exploited but also succumbed to. It is also revealing of the ignorance of the many whose souls are unguarded by philosophy, since, secretly wishing for the same thing, they do not know what it is of erōs that they criticize. Socrates finds, though, a way by which the friendship that Lysias aimed at - one with sexual relations - may be held moderately so as to prevent falling into a hedonistic life. Since "the whole mind" is not committed to sexual pleasure, they will be sparing in it and so remain friends, "but less so than the other two," i.e., the philosophic friends (256c-d). With their minds disordered, these friends will need to make pledges to one another which "they believe to be not right to break" (256d). While only philosophic friends will agree that their unity lies in the

\footnotetext{
${ }^{135}$ This distinction was first made in Socrates' first speech $(237 \mathrm{c3}, \mathrm{c5}, \mathrm{d} 1, \mathrm{~d} 9)$. See Chapter II, note 45.

${ }^{136}$ Burger (27-8), following Rosen (1969 436).
} 
mutual search for true being, these less moderate friends will still reap "no small reward for their erotic mania": they will go into their next lives (and likely spend this life) desiring to become winged so that they may acquire "matching plumage by grace of erōs" and ascend again to the superheavenly place.

Thus, it is "from the friendship of a lover," not the gratification of bodily desires, that "such divine things" are given (256e). In contrast, the non-lover has no claim to friendship, but is merely an "acquaintance" (oikeiotēs), specifically, someone whose benefit is limited to providing for the interests of the household (oikos). In the final flourish of the palinode, Socrates completes his refutation of both Lysias' thesis and Phaedrus's moderation:

The acquaintance of a non-lover, mixed with mortal moderation [and] distributing [oikonomein] what is mortal and thrifty, engenders in the beloved soul an illiberality praised by the majority as if it were virtue. (256e-257a)

Lysias' proposal was not attacked primarily because of its deception or blatant falsity, but rather because it was in service of an ignoble ethic and way of life. The moderation proposed in the first two speeches denigrated erōs for the sake of a wider variety of pleasures, repressing any overwhelming passion for a single object so that it might calculate the best means for attaining all of them. As discussed in the previous chapter, there was no distinction made, beyond following the judgment of the city, between good or bad desires; what seemed to be good was not distinguished from what was truly good, since any goodness was simply derived from moderate enjoyment. The man of mortal moderation will flitter from one desire to the next. ${ }^{137}$ In the language of the palinode,

\footnotetext{
${ }^{137}$ Socrates' account of the democratic man in the Republic is instructive: "He lives by the day gratifying the desire that falls upon him, at one time drinking and listening to the flute, at another drinking water and wasting away, and then again exercising, and again doing nothing and neglecting everything, and then
} 
Phaedrus's moderation, rather than separating him from earthly "images" or "phantoms," instead held his gaze solely upon them in the hopes of unencumbered enjoyment of them all (cf. 258e). This moderation follows from association with a non-lover because without erōs, which desires wholeness in the beloved, there is no impetus to seek out what is truly good, pure, and unchanging - the non-lover and his form of speech can only be guided by what seems to him to be good. So concludes the palinode of Socrates.

\section{$X$. Love and Art}

Socrates now prays to "dear [phile] Eros" for forgiveness on both his own behalf and Phaedrus's, and implores the divinity to receive "the best and most beautiful palinode I am capable of, both with respect to the other things and the fact that I have been compelled [anangkesthai] to speak with some poetical words on account of Phaedrus" (257a). Fearing that Eros would strip him of "the erotic art," Socrates points out that it was Lysias who inspired the earlier transgression, and "was the cause, the father of the speech [logos]" (257b). The palinode has made reparations not simply by repudiating Socrates' earlier thesis concerning erōs, but by attempting to persuade Lysias to change his ways. Lysias must be made to "cease from such speeches" and go to philosophy, "just as his brother Polemarchus has been turned." Polemarchus had participated in the discussion of justice portrayed in the Republic, which Lysias observed silently. Socrates has since that time been unable, it seems, to persuade Lysias, and he now tries to reach him through his friend. ${ }^{138}$ Phaedrus will become the messenger of Eros and philosophy.

spending his time [diatribein] as if in philosophy" (561a-d). The democratic soul does not possess true moderation (559b8-c1, 560c5-d6).

${ }^{138}$ Cleitophon's criticism of Socratic philosophy appears to have been developed in discussion with Lysias (Pl. Cleitophon [Clit.] 406a). 
But this was not Socrates' principal purpose in his palinode. Rather, Lysias must be persuaded for the sake of Phaedrus, so that he too may cease to "play double" or hesitate, "but fashion his life simply towards love with philosophic speeches." For his own sake, Phaedrus must demand speeches from Lysias that do not simply flatter his mortal moderation, but that search out what is best for them. Instead of being a selfishly passive beloved, Phaedrus must turn to Lysias as "his lover." only the slightest philosophic capacities that would be of interest to Socrates, namely his love of speeches, Socrates nonetheless seems to wish to cultivate a philosophic friendship with the beautiful young man, as well as one between Phaedrus and Lysias. Socrates as a lover of Phaedrus is not jealous of this relationship, and even acts as a go-between by which each man may seek something more noble from their friendship. Socrates attempts, as if he were their charioteer, to redirect the passions of the two men.

For his own part, Socrates wishes to retain his erotic art so that he may be "still more than now be esteemed by the beautiful" (257a). But how can he have an art and still claim ignorance? It could be objected that techne does not imply knowledge in the fullest sense, either as epistēmē or gnōsis, but is rather a practical know-how or knack. This is taken up later in the dialogue, but Socrates will there conclude that for someone to have an art, he must have knowledge (epistēmēe $)(268 \mathrm{~d}-\mathrm{e}, 269 \mathrm{~d}) .{ }^{140}$ Socrates is therefore paradoxically knowledgeable and ignorant. This must be the knowledge of ignorance depicted in the palinode, the awareness that erōs is for an absent good. But does this knowledge merely consist of this awareness? Any conventional sense of art could hardly be said to consist of such a bare prospectus. Prophecy, for instance, was divinely inspired

\footnotetext{
${ }^{139}$ Which is also to repudiate the customary division of the paederastic relationship into lover and beloved, erastès and erōmenos.

${ }^{140}$ See also Ap. 22c11-d5.
} 
and so beyond merely human capacities, yet still an art practiced by humans that stood outside mere chance (244c1). Its art seemed to consist in the attainment and production of divine inspiration by which the future could be seen. Perhaps this could be said to be the power of the erotic art, to find inspiration and inspire others, i.e., produce fellow lovers, particularly of the highest things, as Socrates has attempted with Phaedrus. The erotic art would then consist of knowing souls and how they may be moved. It was Phaedrus, after all, and not Socrates, who opposed moderation to erōs and art to inspiration when he said Socrates' inspired description of their resting spot was done "artlessly" (atechnōs) (230c7). ${ }^{141}$ But Socrates himself seemed to offer the same opinion when he said that one cannot be graced by the Muses through the use of art alone (245a). Art then seems to be a practice which works within definite boundaries that mania transcends. A more precise interpretation of that passage, however, shows that Socrates never denies poetry the status of art, but says that it is wrong to believe that art can be separated from mania and still be sufficient:

He who arrives at the gates of the poetic arts ${ }^{142}$ without the mania of the Muses, having been persuaded that he will become a sufficient poet from art, is incomplete [atele] and both he and his poetry, the poetry of the sound-minded [sōphronountos], are overshadowed [or: hidden, $a$ phanizein] by that of the mad. (245a)

The complete art of poetry thus makes its object, and itself, show out or be manifest ekphainesthai, the power of beauty - in a way that the incomplete and uninspired art cannot. The power of the erotic art can be reformulated accordingly: the erotic art is the power to make evident to another the nature of their erōs and their beloved. Yet erōs was

\footnotetext{
${ }^{141}$ Socrates returned this in kind with respect to Phaedrus's love of speeches, but seemed to insinuate that Phaedrus does so in ignorance of the highest uses of speech (242a7).

${ }^{142}$ Poètikas, lit. "poetic things" in the accusative, with the substantive implicit, and the suffix -tikos indicating "relation" or "fitness or ability" (Smyth 858.6).
} 
shown to be, at the highest level, the philosophic search for the divine; that is, a search rather than a pleasant conclusion. The tension between techne and mania is therefore an expression of the tension between search and beauty, or most simply the raising of the question of the nature of beauty. The problem of Socrates' erotic art is, at the highest level, the problem of beauty. In practice, this problematic art demands a choice: either show erōs and its ends, and so beautify and monumentalize it; or engage in the continual search that is erōs, which cannot, in the end, rest in the images and speeches of what it seeks.

Socrates revealed this problem in the practice of his art when he said that his palinode was done "with poetical words" for the sake of Phaedrus - despite saying earlier that poetry will never "hymn" the highest things worthily (247c, 257a; cf. 265b-c). The palinode was itself formed to be the "most beautiful" image of erōs, and by making erōs manifest and attractive to Phaedrus, its true being was hidden. The palinode cannot be understood as a simply frank revelation on the part of Socrates - and indeed he will later say that the palinode only addressed one half of erōs (265b-c, 265e-266e). Instead, the formulations of the palinode must be understood in light of what is known about Phaedrus's character. The final purpose of the palinode was for the sake of persuading Phaedrus and Lysias to a life of philosophy, albeit by misleading Phaedrus about its attendant experience of erōs. In particular, Socrates had to address Phaedrus's love of speeches, fear of pain, valetudinarianism, and tepid hedonism.

The palinode sought to adorn itself with the great pleasure of the release caused by the presence of the beautiful, in imitation of the gods' perfect ascent to, and perception of, true being. Chance itself, particularly the chance of having a Zeus-like nature, was 
suspended in order to show the best possible life. This philosophic life could be construed to be directed towards a most pleasing vision, but Socrates both denied the possibility of a human attaining a complete vision of true being as well of finding any complete rest in whatever vision was attained - the soul is in perpetual motion and the palinode was accordingly a series of cycles between ascent and descent. All life on earth is confronted with toil and pain, and a life of philosophy that refuses gratification in the images of truth cannot be excepted. While Phaedrus's valetudinarianism seemed to be validated by this life of separation from pleasure, particularly by the revelation of moderation itself at the peak of the erotic pursuit, this also means that true moderation lies in the culmination of a mad search, rather than in balancing the desires of the body. Socrates' inspiration of Phaedrus did not forsake his salutary opinion that moderation is healthy. ${ }^{143}$ Each aspect of Phaedrus's character can be found in the palinode, and Socrates deliberately formed the speech in relation to their preceding conversation and actions. Phaedrus could find himself in this speech (see 265c4), but he would also be perplexed by its commingling with the very opposites of what he enjoys. Moreover, with a good memory - which Phaedrus does not possess (e.g., 227e6-228c8) - he would recall many moments in the speech where a crucial proposition was not or could not be elaborated. The most significant of these was the nature of logismos as the means by which the intellect is able to gather together its perceptions, i.e., reminders, of true being. Although necessary for recollection or, still more poetically, ascent towards being, its nature and the manner of how it "is" was not disclosed. While tracing the connection between recollection and erōs indicates that logismos is somehow related or akin to the

\footnotetext{
${ }^{143}$ Recall that Socrates gave those concerned with the health of the body a higher noetic rank than seers, poets, sophists, and demagogues, and praised Acumenus' advice that Phaedrus go for a walk (227a, 248de).
} 
capture of the beloved, how is it that perceptions and the beloved are both reminders? More importantly, why is logismos or recollection even necessary for ascent, and why must it consist of a way of life rather than the production of a single logos? The palinode could be regarded as a beautification of what might seem to many to be the ugly and tedious work of precise argumentation, the beautification of a logos underneath the myth, but Socrates gives no direct argument in the Phaedrus to support this. The persuasiveness of the palinode lies entirely in its ability to reflect back to Phaedrus beautiful images that recall his own experiences.

The use of the mythical form was, however, a curious means of persuasion, given Phaedrus's express distrust of it (229c4-5). Socrates' strategy is full of irony, or, rather, play, for he did not expect it to be persuasive in itself. Phaedrus confirms this when he says that "I pray with you, Socrates, if indeed it is better for us that these things come to be" (257b-c, emphasis added). Socrates' use of fantastic imagery suspends any ready agreement on the basis of literal truth; by proposing images that are fantastic, e.g., that the soul possesses wings, he compels Phaedrus to look beyond received opinion concerning both the definition of the words "wings" and "soul" and their relation. Phaedrus must see, as Socrates showed with his first speech, that definitions and logoi do not exhaust the truth of a thing; he must interpret and ask himself what it means for the soul to possess wings. This mythical talk is a counter to Phaedrus's urbane skepticism, not for the sake of conventional piety, but to open Phaedrus to his own ignorance; he admits to Socrates, "I have been in wonder at your speech" (257c). This was accomplished, for example, through the organization of the palinode in a mythical time that proceeded from a perfect but obscure ancient past ("then") to the modern and 
perplexed present ("now"). In the first place, it put into temporal sequence what actually occurs simultaneously in the present in the experience of longing or desire. A future good is desired on the basis of past experiences that disclosed something concerning good and bad. In its basic form, this is a longing for perfect wholeness. Secondly, the placement of perfection in the past inspires future action towards return. The future is thus understood as a realization of what originated in the past, and the whole of time past, present, and future - is understood to be unified in form. The discernment of timeless patterns is the discernment of the eternal. Accordingly, the third accomplishment of this mythical arrangement was to reorient Phaedrus's comportment to his present objects of desire. The desire that seeks perfect wholeness in them or their future arrangement is to be understood as a degeneration ("forgetfulness"). Phaedrus cannot expect perfection, such as endless pleasure, now or in the future, but only in a way of life that understands the limits of what is possible in our mortality.

The myth of the palinode beautifully depicts the whole in its motion and eternity. The myth presents a compact account of the whole in which logismos participates, if it is to be the discernment of what really is, and yet thereby reveals what logismos can only perceive in part (249b6-c4, 250b1-5). The myth itself thus subjects this beautification to the critique of making monuments. At its very heart, the myth of the palinode points away from itself and its beauty to logismos, that is, to the gathering together of parts. The palinode is, after all, only an image of beauty. This does not mean that Socrates places myth and logos in an irreconcilable opposition. His palinode and his first speech are each 
described as mythos and logos, ${ }^{144}$ and so demand the care required of each form. Neither implies an inherent truthfulness, and myth remains a form of speech; the ordinary meaning that they share is not repudiated. Nonetheless, Socrates' palinode does place its own beautifying synthesis of the whole in tension with the dialogue on rhetoric that is to follow. It remains to be seen whether that dialogue is as much in need of myth as myth was of it. The palinode's manner of showing, namely, that it shows itself to be a showing and not the truth itself, is a call to search that illustrates Socrates' erotic art, and as such it truly finds itself in harmony with the beautiful.

${ }^{144}$ Socrates' first speech as mythos at $237 \mathrm{a} 9,241 \mathrm{e} 8$, and $243 \mathrm{a} 4$, and as $\log$ os at $241 \mathrm{~d} 3,242 \mathrm{e} 3,243 \mathrm{c} 2$, $244 \mathrm{al}, 264 \mathrm{e} 7,265 \mathrm{c} 6, \mathrm{~d} 7, \mathrm{e} 3$, and $266 \mathrm{a} 3$. The palinode as mythos at $253 \mathrm{c} 7$ and $265 \mathrm{cl}$, and as $l o g o s$ at $243 \mathrm{~d} 4,244 \mathrm{a} 3,252 \mathrm{~b} 2,265 \mathrm{~b} 8, \mathrm{c} 6, \mathrm{~d} 7, \mathrm{e} 3,264 \mathrm{e} 7$, and $266 \mathrm{a} 3$. 
IV

\title{
THE ART OF SPEECH
}

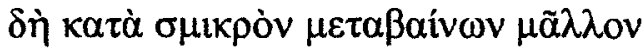

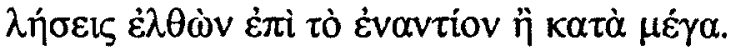 \\ Indeed you will escape notice more readily \\ when crossing over to the opposite by proceeding \\ along small steps rather than large ones.
}

The beauty wrought by Socrates' art in the palinode impressed Phaedrus, but did not persuade. Phaedrus's qualified praise, "if indeed these things are better," shall become a familiar refrain, for what is beautiful indeed fills and pleases him, but does not itself satisfy $(257 \mathrm{c})$. The showing of the erotic life is therefore not yet complete, despite the lavishness with which Eros has been redeemed. Whatever truth is contained in the palinode has not been made sufficiently clear to Phaedrus that he will take it into his life and consider devoting himself to the highest erōs and so to "philosophical speeches." The immediate cause of Phaedrus's doubt is his lingering attachment to Lysias. Phaedrus fears that Lysias, in the contest with Socrates, will "appear to me wretched," for he is not present and will have to write another speech. That Lysias must write seems to be something shameful to Phaedrus, for he once heard a politician abusing his friend by calling him a "speechwriter," as if writing rather than actually delivering speeches or speaking extemporaneously was inherently contemptible. A rift between Phaedrus and Lysias had therefore been opened, and Socrates' speeches have threatened to widen it further. This pragmatic concern of a man for the true beauty of his friend raises the question that animates the remainder of the dialogue: what is beautiful or noble writing? How may Lysias become truly beautiful? Dramatically, then, the question of the nature of the art of rhetoric is subordinate to the question of writing, even though the dialogue 
will demonstrate the former to in fact be the primary philosophical question. Erōs as embodied in the lives of the interlocutors is what animates the dialogical inquiry into art. Through this embodiment the promise of the palinode, that it persuade Phaedrus and Lysias to philosophy, may be fulfilled and the two halves of the Phaedrus unified, as Phaedrus seeks true beauty as it is found here on earth in its particular manifestations. This chapter will show that the whole discussion of the art of speech is an exercise in Socrates' erotic art. In demonstrating how a true art of speech entails knowledge of both the subject matter and what is fitting for the soul of the audience, as established by dialectical study and demonstrated through teaching, Socrates indicates how the present inquiry, and speech in general, presupposes or implies an erotic relation to its principal object, "the fitting." What is fitting can neither be acquired through specific logical techniques nor established in a definitive demonstration, but only embodied in a life dedicated to its pursuit. Dialectic and the true art of rhetoric are thus promulgated as the final end and perfection of inquiry into soul but are in practice subsumed under Socrates' erotic art, thereby reforming the current practice of rhetoric under the guidance of philosophy.

\section{Lysias' Shame}

Phaedrus expresses the concern that the politician's abuse will cause Lysias "to cease from [lit. restrain himself from] writing out of love of honor [philotimia]" (253d6). What is "better" for him and Lysias is not understood in the highest terms outlined in the palinode, the philosophical pursuit of true knowledge, but in the terms of "the coarser way of life" $(256 \mathrm{c} 1)$. Socrates' shame was before a god, while Lysias' shame is before 
men. Phaedrus thus reopens the question of the best life in the context of Lysias' art of writing, not yet persuaded that he should leave behind the opinions of men. But Socrates tells him that he has gravely mistaken Lysias, if he believes that his friend is susceptible to the politician's abuse. It is not Lysias, then, who is ruled by love of honor, but Phaedrus, who projects himself upon his beloved and misses the mark because he fails to understand himself. His love of honor was, after all, one of the reasons why he was susceptible to the seduction of Lysias' non-lover (231e-232a).

Phaedrus's lack of self-understanding is a consequence of his ignorance of the full nature of erōs, which demonstrates how the palinode did not persuade him. He believes that politicians scorn writing because they too fear for their "future reputation [doxa]" and do not want to leave behind such trifles "lest they be called sophists" - a fear that indicates the problematic position that these itinerant teachers had come to assume in Athenian life, being both in demand and reviled for their cleverness in speaking (257d). Socrates does not deny this fear for their reputation, but rejects the belief that it is a repudiation of writing simply: "have you forgotten 'the sweet bend' that is named for the long bend along the Nile?" That is, the politicians say one thing yet do another. Politicians are also lovers and their principal instrument in this is writing, since "the greatest thinkers" amongst them spend their time trying to have their laws acclaimed by the assembly and written down (257e). Thus their love of honor is also a part of erōs, binding one not to a single beloved, but many. The politicians wish to see themselves reflected in and loved by the dēmos as a whole, and so write their beloveds first: "the writer says 'it seems best to the council' or 'to the people' or both, and 'such a man said,' speaking of and praising himself with great reverence" (258a). Thus the politician enacts 
in "the theatre" of the assembly the great encomia of the poets, but with himself as the object, realizing his self-love and desire for immortality. The politician lives on in the memory of his fellow citizens through this writing. The mere mention of the Spartan Lycurgus, Athenian Solon, and Persian Darius, is sufficient to show how a legislator's name may transcend both time and place.

Legislation is the third form of immortality mentioned in the Phaedrus. The first was the impossible immortality of the body popularly ascribed to the gods, the second the eternal life of the winged soul. It would not be wrong to see here the origins of the dispute between Socrates and Plato on the immortality of the logos, which is expressed in the later discussion of writing. Socrates qualifies the immortality of fame produced through the writings of poets and legislators: the legislator is like "a god" until he dies, being subject to the higher (and unwritten) ordinances of nature, ${ }^{1}$ and lives only as a memory recalled when future generations "gaze upon his writings" (258c-d). What immortality he gains is thus dependent on its durability on earth, as Socrates points out when he mentions the sadness of the politician "when his writings are rubbed out." This immortality is a dim reflection of the eternal being seen by the mind, and produces custom and habit rather than knowledge. ${ }^{3}$ Keeping in mind this difference, introduced in the palinode, it is evident that the persuasion affected by law is consequently a mixture. In the first place, it is the persuasion of the souls of the assembly, making them willing

\footnotetext{
'E.g., in the cosmology of the palinode there is found "the ordinance of Adrasteia" and "the law" that a soul that saw the beings shall be planted in a human seed (248c2, c8).

${ }^{2}$ This echoes the dispute between the mantic seer Diotima and the poet Aristophanes in the Symposium. Diotima repudiates Aristophanes' celebration of political virtue as the striving after a form of immortality that is far surpassed by the immortality of being with the eternity of true beauty itself (Smp. 207c 10-d 2 , 208c3-209e5, 211a6-b6, 212a3-10; cf. 191e7-192el2).

${ }^{3}$ The subtle difference in the words used to describe the observing of the superheavenly place, theörein, which connotes the witnessing of an oracular pronouncement, and the seeing of the law, theaesthai, which means to gaze at, albeit often with a sense of wonder, emphasizes the different levels of these respective visions and immortality.
} 
participants who believe in the goodness - for whatever reason - of the proposed laws. Rhetoric precedes legislation and must appeal to principles higher than those found in either the current or future law. What had previously been a matter of debate therefore becomes determinate and even customary or habitual in the broader sense of nomos. ${ }^{4}$ Next, the law must continue to persuade over time. Law provides a fixed meaning to words such as justice, crime, property, etc., permits or proscribes certain actions, and defines relations between rulers and ruled; it is literally the making of custom. Law, however, does not itself teach, for writings are static, as Socrates later says, "always saying the same things," and are only "reminders" (275a, d-e, 276d). The greater force of law lies in its compulsion of assent, which is not mentioned here, and was only alluded to at the beginning of the Phaedrus in the mention of the Areopagus, which tried cases punishable with death $(229 \mathrm{c})$. The restraint of the horses in the palinode, either by the threat of shame or bodily pain, is a vivid metaphor for this form of rule, which, so far as souls ruled by mind alone are rare, is laid on the multitude. Thus the immortality of law is not won simply by persuasion, but in large part by its power over the body and the lower parts of the soul.

Legislation as a form of "writing" is a far cry from the writing of "speech-writers" like Lysias, and so it is not surprising that the argument of the "sweet bend" of the politician would be lost on the politician himself, or Phaedrus. Phaedrus's acceptance of the argument is tepid: "it is not likely [eikos] [that the politician reproaches Lysias for being a writer] from what you say, for he would reproach him, so it seems [eoikein], for what he himself desires" $(258 \mathrm{c})$. The response that "it is likely" is a common refrain for Phaedrus, whose hesitance to agree emphatically indicates a wariness concerning the

\footnotetext{
${ }^{4} \mathrm{Lg}$. 793a-d. On the broader meaning of nomos, see Chapter II, note 9.
} 
argument. This hesitation proves to be a helpful guide for the reader of the Phaedrus, as closer examination of Socrates' arguments often reveals a subtlety that eludes Phaedrus in the quick flow of conversation. The demonstration that the politician's abuse of Lysias is self-contradictory, for example, raises the question that, if this is true, why then does the politician abuse Lysias? Perhaps he is ignorant of his desire for self-immortalization, but perhaps he also draws the rather obvious distinction between the writing he performs and that of Lysias. Strictly speaking, they may both be speech-writers, but perhaps the politician finds Lysias' to be shameful. Lysias' forensic writing is, after all, directed at securing a beneficial verdict for his client, perhaps evading the punishments commanded by the law, and so undermines the monument of justice by which the politician is immortalized. ${ }^{5}$ Moreover, Lysias himself does not enter in the contest to found lasting legislation, but contents himself with his timely pieces. ${ }^{6}$ Socrates thus fails to distinguish between kinds of writing, i.e., noble and shameful, but quite intentionally, for that distinction can be clearly made only after the long discussion of the nature of rhetoric itself. Indeed, it was because Phaedrus, not Socrates, initially failed to make that distinction that the present argument is persuasive. That Lysias' particular form of writing may deserve abuse is a point that Socrates politely passes over in silence, but did allude to when he claimed that the urbane speeches were dreadful, and now alludes to by stating the truism that "what is shameful is speaking and writing not nobly [or: beautifully, kalōs] but shamefully and badly" (242d, 258d). Socrates reserves the direct

\footnotetext{
${ }^{5}$ E.g., Defense Against the Charge of Taking Bribes (Lys. 31 ).

${ }^{6}$ None of Lysias' extant writings nor ancient commentary on his career evidence an interest in this higher art of writing. That he was a metic would of course have presented an obstacle to such political participation, but it would be no more formidable than participation in forensic disputation, which he of course achieved in an indirect manner. Lysias did write a rhetorical defense of Athens's democratic constitution, Against the Subversion of the Ancestral Constitution of Athens (Lys. 34), but that could in no way be construed to be legislation.
} 
censure of Lysias' manner of writing until he has solicited Phaedrus's agreement to the principles necessary for that censure.

In this discussion of Lysias' shame, Socrates saves the possibility of good writing, and in doing so links writing to politics, legislation, and self-immortalization. The return of political life to the conversation gathers together the full range of subjects, and stakes, of logos and the art of rhetoric, far beyond the private uses seen in the earlier speeches. Socrates asks Phaedrus, "what is the manner [tropos] of writing nobly and not? Do we need to examine [exetazein, from zētein, to search or inquire] whomever else has at some time written something or will write, either a political or a private writing, in meter like a poet or without meter like a prose writer [or: private man, amateur, idiōtēs]?"' (258e). The question that Phaedrus and Lysias should concern themselves with, Socrates suggests, is a universal one, which in answering will disclose goodness of writing in all its forms - a claim that is on the face of it incredible, for he implies that the following discussion will reveal what is good poetry, good legislation, good rhetoric, and so on, regardless of audience, subject, and time. Socrates' later insistence that speech be formed in relation to such particularities will have to be reconciled with this intention to discuss writing simply.

\section{The Immortal Song of the Cicadas}

The discussion of the nature of writing is quickly led into a digression that will develop into the lengthy examination of the art of rhetoric. This digression arises from Phaedrus's peculiar delight at the prospect of examining Lysias' speech. His sentiments are decidedly un-Socratic, not born from that higher zêtesis depicted in the palinode, and 
therefore crucial for understanding his character as a lover of speeches (228a-c). He tells Socrates: "for the sake of what else would one live, but than for the sake of such pleasures?" (258e). Unlike Socrates, who also described himself as a lover of speeches, Phaedrus pursues speeches of all sorts not as an instrument for the love of learning but for pleasure. The first example of this entirely aesthetic love of speeches was Phaedrus's praise for the form of Lysias' speech rather than its substance (228b-c, 230d3, 234c6-7, 236e4-5). The problem this presents to Socrates is whether inquiry can be conducted for the sake of such an end, or is thereby essentially compromised. ${ }^{7}$ Phaedrus, for his part, must show why pleasure is for him not only good but also the highest good "for the sake of which one would live." Phaedrus reasons that one lives "not [for the sake of] those [pleasures] which it is necessary to feel pain before or not take pleasure in, which indeed all the pleasures concerning the body have a small part of, so that they have also justly been called slavish." The highest principle of Phaedrus's life is a hedonistic calculus, albeit directed at a sort of purity that would rather minimize pain than find the greatest pleasure; a great pleasure mixed with pain is of little interest to him. This seems to be a misinterpretation of the transcendence of the palinode, for Phaedrus effectively cuts himself off from the greatest of pleasures, which arise from the relief of pain (see 248c25,251c1-252a1) (but Phaedrus's view also seems to correspond remarkably well with the concealed lover's implied promise of pleasure that is free of the harmful madness of bodily erōs [239a-e, 24le6-7]). If the soul's philosophical return to the superheavenly place depends on successive experiences of the erotic pain of separation and then joyful vision, Phaedrus's present understanding of both speech and erōs prohibits any such

\footnotetext{
${ }^{7}$ Pl. Philebus (Phlb.) 21a-b. In the Republic, Socrates is unequivocal that the highest good is not pleasure, yet later argues that the life of philosophy is a pleasure unmixed with the pains of the body $(505 \mathrm{c}, 509 \mathrm{a}$, 583a-587a).
} 
return from the very outset - and he will indeed express wariness concerning the exertions of a philosophical life (272b5-6, 274a6-7). Moreover, Phaedrus understands pain as solely physical, rather than the psychical pains of erōs depicted in the palinode, which produces a curious form of hedonism that holds the body in contempt and manifests itself in his valetudinarianism.

The superficiality of Phaedrus's soul shines through here, as his concern is not for learning but gratification (e.g., 235b) ${ }^{8}$ In the Symposium, Socrates discovered that his incessant questioning and refutation held no special charm for Phaedrus, who was bent on eliciting the rhetorical displays on Eros: "I on the one hand listen with pleasure to Socrates' conversations, but on the other hand it is necessary for me to care for the encomium to Eros." 9 This later elicited the rejoinder from Socrates that Phaedrus must decide "whether [he] needs any speech of such a sort, [and wishes] to hear the truth told concerning Eros, in whatever sort of words and arrangement of phrases that may happen to occur." power to grip the soul in pleasure has proven to be particularly suitable for Phaedrus. In order to refute Phaedrus's aesthetic understanding of speech, Socrates must find a way to approach the problem that will be suitably attractive to his younger friend while at the same time does not compromise its serious purpose.

Observing that the cicadas that sit above their heads in the plane tree sing in the midday heat, Socrates notes that they have leisure to pursue this digression. He tells

\footnotetext{
${ }^{8}$ Compare the Athenian Stranger's argument that a teacher must find a middle ground between the absence or presence of pain when educating a youth $(L g .729 \mathrm{~b}-\mathrm{e})$.

${ }^{9}$ Smp. 194d.

${ }^{10}$ Ibid., 199b.
} 
Phaedrus that they must continue conversing in order to resist the song of the cicadas. If the cicadas saw them,

like the many who in midday do not converse but doze, being charmed by them [the cicadas] on account of their lack of employment [argian] of the mind, they would justly laugh, thinking some slaves had come to their retreat in order to take their midday nap around the spring, like sheep. $(259 \mathrm{a}-\mathrm{b})$

Phaedrus's urbane sentiments are thus quickly reversed: an examination for the sake of pleasure is akin to sleeping; leisure should not be lack of employment (argian is the privative of ergia, "work" or "activity"), but activity of the mind; what is truly slavish is to forgo the exertion of the mind for the sake of gratification. Dialogue versus sleep is the difference between Socratic and Phaedrean speech, such that what is at risk for the two of them is not merely the possibility of a real examination of Lysias' speech, but with it the possibility of speech ever grasping a reality of greater meaning than the pleasures it may generate. "1 The superficiality of Phaedrus's erōs threatens to turn speech into an empty instrument that would dwell undisturbed with falsities such as those found in Lysias' "non-lover."12 Symbolically, the shade under the plane tree - the light mingled with darkness - comes to express these two ways of orientation towards the logos. The sun rose to its apex over the course of Socrates' palinode, but its "stifling heat" now threatens to destroy the conversation. They can either revel in the relief provided by the shade, and thereby lose sight of the true beauty in writing that should be their concern, or

\footnotetext{
"Pace Klein (15), who argues that the purpose of the myth is to restore orality to its proper place. The immediate context, and Phaedrus's remark at 258e, indicates that the issue is Phaedrus's manner of conversation. This is not to say that this is unrelated to the criticism of writing discussesd in Chapter V and Phaedrus's own interest in writing.

${ }^{12}$ Socrates expresses a similar sentiment elsewhere: in the Protagoras, he voices his contempt for dinner parties devoted to interpreting a poem in a variety of ways (Prt. 347c-e); in the Symposium he rebukes the encomia to Eros inaugurated by Phaedrus for their abject falsity in ascribing to the god everything thought $\operatorname{good}($ Smp. 198b-199b).
} 
they can use that shade as an opportunity to understand the preceding experience $(258 \mathrm{e}-$ 259a).

Should they follow the latter way and employ their minds in conversation, the cicadas will see the two "sailing by them un-enchanted as if they [the cicadas] were Sirens" and give them "the gift for human beings that they have to give from the gods" (259a). Socrates' appropriation of the story of Odysseus' escape from the Sirens is revealing. In Homer's story, Odysseus followed the divine counsel of Circe with regard to his men and instructed them to stop their ears, but he himself contrived a way so that he could listen to the terrible song of the Sirens, which promised wisdom, and so instructed his men to fix him to the ship's mast. ${ }^{13}$ Through this device, he was temporarily driven mad by the song yet nonetheless escaped the Sirens' island meadow that had been filled with their victims' corpses. ${ }^{14}$ Socrates' allusion has two implications. First, his advice to converse despite the cicadas' song rejects the division between the ignorant men and divinely counseled Odysseus, and so makes a principle for all human beings the Odyssean wisdom to both hear the song and guard against it. Second, he transposes the Sirens' island of death onto the grove of the plane-tree, which has been the source of Socrates' inspiration (230b-d, 241e, 242d-c, 263d). Life and death are now bound together in the grove. ${ }^{15}$ As is fitting in a place that provides respite from the sun, the myth of the cicadas will express the limitations that mortality places on the divine ascent depicted in the palinode.

\footnotetext{
${ }^{13}$ Hom. Od. $12.39 \mathrm{ff}$. On the promise of wisdom, see 12.188.

${ }^{14}$ Hom. Od. 12.45-6.

${ }^{15}$ The theme of an eternity that transcends life and death was first seen in the myth of Boreas' murder or divinizing of Oreithuia, and the Eleusinian allusions that recall the marriage of Persephone and Hades.
} 
Socrates tells Phaedrus that it is "not fitting" for a "devotee of the Muses," a philomousos such as Phaedrus, to have not heard of the origins of the cicadas and how they came to bear a divine gift (259b). The cicadas, Socrates tells Phaedrus, were once men, before the Muses were born. When the Muses and their song came to be, these men were "struck out by pleasure" and devoted themselves to singing with such ardor that they "neglected food and drink, and did not notice that they had died." From these men, "the race of cicadas grew," being pitied by the Muses. They subsequently take the Muses' gift and sing until their death, after which they go and report on those who had honored the Muses in each of their respective domains, whether it was Terpsichore in dance, Erato in "love matters," and so on. But "to Calliope, the eldest, and Ourania who follows her, they report those leading a life in philosophy and honoring their music, who indeed amongst the Muses are most of all concerned with the heavens and speeches [logos] both divine and human" (259b-d).

The dual purpose of the myth - both a warning and a call to honor the Muses seems to originate from the nature of the undying song of the cicadas. In his version of the origins of music, Socrates seems to be in agreement with Hesiod, that although the Muses bring "a forgetting of ills and a rest from sorrows," a life without pain and laborious struggle is impossible. ${ }^{16}$ When song "appears" - it was not born, but hidden it "strikes out" men. This moment of being "struck out," which Socrates playfully enacted after hearing Lysias' speech, is the moment of ecstasy when the soul lays hold of what is pleasing because it seems to satisfy the most fundamental desires (cf. 251a252a). ${ }^{17}$ Having found the source of great pleasure, the soul refuses to part with it, but

\footnotetext{
${ }^{16}$ Hes. Th. 53-61; cf. Pl. Phd. 60b-c.

${ }^{17}$ See also Smp. $211 \mathrm{~d} 7$-el.
} 
the fate of the ancient men shows that an everlasting grasp of the beautiful and what is pleasing is outside the power of mortals. By neglecting their bodies in their eagerness to be filled with pleasure, these men spurn a truly human life, and are reborn in sub-human form. Socrates earlier said that no soul that had glimpsed the truth would "be planted in a beast," and now it seems that even the highest rank of soul, a philomousos, might, because of its natural ability to recall beauty, spurn the form that most of all would allow for the return to true being (248c-d). The cicadas lose sight of being because they lose sight of their mortality. The argument is not that death is an inherent evil and the ancient men were fools for allowing it to happen, ${ }^{18}$ but that their obsessive indulgence in the pleasures of song led to the obliteration of "the human form" (249a-c). Pain and death may in fact be good so far as they are reminders that the truth of being is hidden.

The cicadas' song is thus a test, bestowing a divine gift to those who hear it and honor the Muses but do not delight in the deceptive song alone, as Hesiod famously sung: "we know how to speak many false things that resemble the genuine [or: true, etuma], but we [also] know, when we may wish, how to sing true things." ${ }^{.19}$ Perhaps the substance of the ambiguous divine gift lies in this, the disclosure that logos is dualistic, both "human and divine," and so an instrument for gratifying what is merely human or what is divine. ${ }^{20}$ These two forms of logos had been identified twice before, in the distinction between the divine and human ways of telling what the soul is, and between the Homeric and divine verses on Eros (246a, 252b). Each distinction pointed to a higher but

\footnotetext{
${ }^{18}$ Burger rightly points out that Socrates' own testimony indicates that he did not believe death to be simply evil (74). In Plato's Apology, Socrates implies this when he notes, after his death sentence, that his daimonion, which holds him back from what is bad, never restrained him throughout his acerbic "apology" - perhaps it was good that he would come to die in the way he did ( $A p .40 \mathrm{a}-\mathrm{c})$.

${ }^{19}$ Hes. Th. 26-8.

${ }^{20}$ Ferrari plausibly argues that the gift is a good report to the Muses, which the cicadas do bestow (Ferrari 1987 27). But for a man like Phaedrus, who is skeptical concerning myths and gods, and perhaps for many readers of the Phaedrus, the utility of this good report is not at all evident.
} 
inscrutable way to the complete nature of things. If philosophy cannot be said to be the divine way simply, it is at least the form of music, as Socrates interpreted it throughout his life, ${ }^{21}$ which seeks to couple the logos with what is heavenly. The philosopher would be a true devotee of the first Muse, Calliope, whose name is "Beautiful vision."

The implication of Socrates' myth is that the form of Phaedrus's love of speech does him no good, for it conflates the pleasant and the good, and the pleasant may very well be harmful, whether this is understood to be the singers' deaths or their ceasing to be human. Phaedrus must develop an awareness of how deceptive his present desire for pleasure can be, particularly when it affects the very logos necessary for understanding what is truly desirable. The emptiness that logos is capable of arises from its departure from the sheer necessities of life and the concerns of the body. Although this risks producing the opinion that the pleasant separation from necessity is the highest good, it nonetheless allows for the discernment of a good that is greater than mere survival. The tension that mortality induces between the necessities and pleasures of life cannot be reconciled simply in favor of pleasure, as the cicadas believe. Indeed, Phaedrus's enduring respect for medicine and his observance of its prescriptions, can - and will - be cultivated as a source of insight into how the desirous nature of human life points beyond the incessant "filling up" on pleasures. Logos is thus used by Socrates with an eye towards its utility for a human life that is greater than either mere survival or the enjoyment of a licentious freedom.

\footnotetext{
${ }^{21}$ Phd. 60d9-61 a5. Socrates comically portrays himself as inept and graceless with conventional music because of his devotion to the higher music of philosophy. He blames his failure to become musical on his incessant questioning of the lessons of his music teacher, Connus (PI. Euthydemus [Euthd.] 295d-e). The distinction that Socrates makes in the Phaedrus between the susceptibility of the philomousos and the highest music of philosophy indicates that the mousikos in the palinode is not simply a property of the philosopher, but an independent life of its own. See Chapter III, note 68.
} 
To this dimension of Socrates' story of the cicadas can be fruitfully appended Ferrari's interpretation of the passage, which sees the reemergence of the "background" or setting of the Phaedrus as an enabling condition for the possibility of dialogue. ${ }^{22}$ The dramatic function of the grove that is graced by the cicadas, which at times emerges from the background, is coextensive with erōs, understood as the desire to unite with an object that is absent yet somehow already known. There is a "background" presupposed and implicit in human action, in which the causes of its own being are found. The "human form" is uniquely capable of perceiving and inquiring into this, and it is the logos that does not merely assume or take for granted that background that is truly human. It is the logos that opens the soul to the nature of being. The present manifestation of the background coincides with a story about the death of the body because mortality is a fundamental neediness that reminds Phaedrus of his ignorance of what is truly everlasting.

Socrates' story is also a useful remedy for an urbane intellectualism that turns itself away from the pragmatic, unpleasant, even painful, and ugly or ignoble aspects of human life. The subsequent discussion of rhetoric and knowledge accordingly turns on the relationship between knowledge and use.

\section{Rhetoric and Knowledge}

With the warning of the cicadas delivered, Socrates returns to the inquiry into speaking and writing nobly. Speech will not be used simply for pleasure and gratification, but for the sake of finding what is good and useful. Socrates' very first argument is met with a response that will not be addressed to the satisfaction of either

\footnotetext{
${ }^{22}$ Ferrari $198721 \mathrm{ff}$.
} 
man for the remainder of the discussion of the nature of rhetoric. Socrates asks Phaedrus to agree that speaking "well and nobly [or: beautifully, kalōs]" requires that "the mind of the speaker knows the truth about what he is about to speak on" (259e). There is a small but significant change here from Socrates' previous formulations of the inquiry: he has added "well" to the character of speaking and writing under investigation (cf. 258d7, 259e1-2). This subtle distinction between the good and the beautiful seems to be a consequence of the digression about the cicadas, which qualified Phaedrus's love of speech, particularly beautiful speech. This establishes a link between knowledge and goodness, although it is not clear if this implies that the knowledge that a rhetorician must possess includes the goodness of the things in question, let alone the goodness of the rhetorician himself. Regardless, Socrates sets a high standard for speaking well, particularly if this knowledge is understood as "true knowledge" of the beings themselves $(247 c-e)$

Phaedrus's negative response is predictable, given his purely aesthetic interest in speeches. As such, it seems to have been deliberately prompted by Socrates for the purpose of examination (and ultimately refutation). Phaedrus says:

I have heard that it is not necessary for the one who intends to become a rhetorician to understand the just things in reality but what seems so [ta doxanta] to the majority who judge, nor the truly good nor beautiful things but what will seem so [dokein], for persuasion comes from these things and not from the truth. (259e-260a)

This is an important opinion that bears closer analysis before considering Socrates' response. Phaedrus's resort to hearsay, "I have heard," is now familiar and reflects his approach to speech, which adopts positions without having considered their merit for himself (e.g., his fascination with Lysias' speech). But beyond this characterization of Phaedrus, Plato's introduction of this opinion with "I have heard" hints at the problem in 
the claim being made: Phaedrus could not claim "I know" that knowledge is unnecessary without contradicting himself, nor could he simply say "It seems to me," which would only confess that the opinion is itself not true because opinions are not true. ${ }^{23}$ Phaedrus's choice of words is a tacit admission of this incoherence that creeps in through his reliance on a vague authority. Socrates will not be concerned with the precise source of this opinion, only whether it is true, but it does call to mind Gorgias' claim that he teaches his students how to talk about justice and persuade others without knowing what is truly just or making themselves just men. ${ }^{24}$ There is a certain common sense to this belief, which may explain how it has come to Phaedrus, in that speech can be performed without knowledge and even effectively. But how can it be that we can persuade others of what only seems to be, i.e., what is not, if we do not know what is? The problem expressed in Phaedrus's opinion is not a small one, and will reemerge at crucial junctures in the conversation. The opinion is "not to be cast aside," Socrates says, quoting Nestor. He recalls the noble tradition of public speaking that sought to lead a recalcitrant audience to the correct opinion held by the speaker, rather than the duplicitous speech that abounded in both public and private. This latter, deviant, mode of speaking has now come to prominence. $^{25}$

In the Iliad, Nestor's words persuaded Agamemnon to muster the army by nation and clan so that they may be addressed and persuaded of the decision of the council. ${ }^{26}$ Socrates takes up this motif of battle to show how persuasive rhetoric must address itself

${ }^{23} S p h .237$ a ff.

${ }^{24}$ Grg. 457b-c, 459c-460a; Men. 95c.

${ }^{25}$ Two examples of the noble rhetoric are sufficient to show its legacy: the address to the mustered army in the Iliad aims to win the soldiers over to decision of the council of kings (Hom. Il. 2.72-4); Aeschylus' Pelasgus enters the assembly to persuade the citizens to heed the strictures of justice despite its risks (A. Supp. 468-89, 516-23).

${ }^{26}$ Hom. Il. 2.361. 
to a sort of knowledge that the audience has acquired through use and experience. An utter absence of knowledge is impossible: "If I were persuading you to defend against enemies by acquiring a horse, and neither of us knew what a horse was, but I happened to know so much about you, that Phaedrus believes a horse is that animal of ours that has the greatest ears..." (260b). A rhetoric that could somehow grasp the opinions of its audience, without having any grasp of what it is an opinion of, would be incomprehensible or "ridiculous," as Phaedrus says. Socrates carefully qualifies this, arguing it only becomes ridiculous when he "puts together a speech praising the donkey, naming it a horse and saying the beast would be an entirely valuable acquisition for both home and on campaign, useful both to fight from and able to bear baggage and many other purposes" (260b-c). The ridiculousness of this kind of rhetoric depends on the unexpressed premises that a donkey would be useless for fighting and that such uselessness would be evident to the owner. The ignorance of the buyer and seller, and the seller's deceit, is only exposed by this use; so long as the object remains in speech alone, and is not brought to the test, it can maintain the guise of truth. Socrates therefore does not argue that false opinion is impossible, but only that it will eventually be refuted by experience. Action and experience imply some knowledge. There is no real knowledge of what is said until the speech can be brought into deed and reconciled with its supposed function, ${ }^{27}$ although it is unclear if this holds for all knowledge, including those forms that are outside of direct empirical experience, such as mathematics. ${ }^{28}$

\footnotetext{
${ }^{27}$ Socrates uses the same argument in book ten of the Republic, but for the opposite purpose of refuting the opinion that a poet who imitates but does not use a thing has knowledge, rather than showing that there is some knowledge implied in persuasion (see $R .601 \mathrm{~d}-602 \mathrm{a}$ ).

${ }^{28}$ Socrates does not entertain this question here, but the divided line in the Republic indicates that mathematical knowledge is subordinate to knowledge of the ideai, the highest of which is the idea of the good (Ibid., 508b-509a, 510c-b, 511d). Knowledge of the ideai is attained through dialectic that ascends from sense experience through general hypotheses, and then back down to what is sensible (511b-d, 533a-
} 
Moreover, Phaedrus could object that use is no simple thing, as Socrates himself mentions, and were the owner to also employ the donkey in other tasks besides war, he would not necessarily know he was not sold a horse, but believe he only had a rather limited one; surely the knowledge of what is a horse also depends on speech that can grasp in a single form the many properties, including uses, of a horse. The example of war and success in battle was thus deceptively clear, and this deceptive clarity is even more pronounced when Socrates applies the argument to the usual objects of rhetoric mentioned by Phaedrus - "just things," "good," "beautiful."

Socrates uses the example of political deliberation to return to the broader scope of rhetoric, in which the fate of the city is at risk. Phaedrus's ethic or comportment to speech has serious political implications. If a rhetorician who is ignorant of what is good and bad addresses a similarly ignorant city, "and persuades them ... about bad as if it were good" and to do bad rather than good "by having practiced the opinions of the majority," he will "reap" from "this rhetoric" a bad fruit (260c-d). Rhetoric that is unconcerned with knowing the objects of its speech will inevitably make mistakes and produce the opposite of what is intended, if indeed the rhetorician intended to produce justice and goodness in the city. This kind of rhetoric, if it is not simply malicious or for the sake of self-aggrandizement, is unable to determine which of the opinions it had studied should have been inculcated. Socrates' deduction is faultless, but the question is whether the city will notice that it had been deceived and consumed bad fruit. Is injustice as evidently useless as a mule is for war? Socrates' argument depends on Phaedrus

534d). If this comports with the argument of the Phaedrus, and book ten of the Republic itself, it is therefore the reconciliation of the highest parts of knowledge with the particular things of sense experience - the putting of one's hypotheses and theorems, and the principles upon which they rest, to use - that constitutes true knowledge. 
believing that the nature of justice, goodness, and beauty are sufficiently obvious that someone would soon discover they had been deceived when putting these opinions to use, assuming they would even know what use these things serve (Socrates deduces the reaping of bad fruit by only actually using the word "bad," an obvious truism, rather than injustice and ugliness). These are all things that Socrates will later describe as "disputable" in their meaning, and indeed the palinode showed each to be visible to the mind alone rather than discernable to the senses like a horse (263a). If the majority in the city were to content themselves with mere opinions concerning justice, goodness, and beauty, it would prove difficult for the soul of a single citizen to find for itself the truth concerning those things and thereby ensure that the chariot of his soul was pulled by war horses rather than donkeys. Without knowledge of the use of these things and of "bad fruit," the question still remains whether we can persuade and be persuaded with regard to what only seems to be true. Phaedrus does not, of course, raise this objection, and accepts the analogy of the seemingly self-evident uselessness of the donkey to the uselessness of injustice and ugliness. Socrates already saw how Phaedrus fails to distinguish between pleasure and good, and relies on what he "heard" for his opinions, so it was not much of a stretch to see that he would also accept this analogy. Phaedrus is one of "the majority" on whom Socrates seems to use his own rhetoric.

\section{Psychagogia}

Rather than take the issue of rhetoric and knowledge to have been settled, Socrates reformulates the claim of rhetoric so that it does not deny knowledge, and therefore its own possibility, but is necessary for all skillful persuasion. He personifies 
the art (technē) of speaking, who chastises them for thinking she wants them to be ignorant of the truth. Instead, she advises the one who intends to become a good speaker to learn the truth before taking up the art. But she also boasts that "without me [i.e., the art], the one who knows the beings will not be able to persuade by art" (260d). It is important to note at the outset that Socrates' discussion of this boast is a subtle one that refutes neither the boast nor the rhetoricians' power to persuade a crowd, even if they lack this art - the truism that without the art of persuasion there is not artful persuasion leaves open the possibility of artless persuasion. But the boast is necessary if the art of speaking is to be an art in its own right and has a subject matter independent of the other arts. This separation of persuasion from the other arts in fact greatly expands the scope of rhetoric, for if rhetoric is necessary for any artful persuasion, even the practitioners of the other arts will have need of rhetoric - perhaps even to learn and conduct their own art. Otherwise, the knowledge contained in those arts could only somehow be given beforehand, without persuasion, or acquired through an artless persuasion, which seems unsatisfactory for any real art. This also implies that the nature of knowledge is such that it cannot be simply communicated or made manifest, as if it were some parcel to be simply shown and given to another. ${ }^{29}$ The claim made by the art of rhetoric is thus even greater than the one made by Gorgias, that a physician can use a rhetorician to deal with recalcitrant patients, ${ }^{30}$ for it extends to persuasion simply.

Socrates does not reject the great claims made by the art of speaking, and actually agrees, with the qualification, "if she is indeed an art" (260e). Accordingly, he wishes to

${ }^{29}$ The boast of the art of speaking contains the whole problem of what knowledge is and how one acquires it, which is discussed in the Theaetetus, and rules out the "aviary" model of knowledge (Tht. 197c-200c, esp. 198a-b; cf. Smp. 175d-e).

${ }^{30}$ Grg. 456a-457b. 
consider whether the art of speaking "lies," and is no art at all, but an "artless knack"which if true would refute her claims while acknowledging rhetoric's capacity for persuasion. Socrates characterizes the objection as Spartan: "of speaking, says the Spartan, a genuine [or: true, etumos] art without having laid hold of the truth [alètheia] neither is nor will ever come to be later" $(260 \mathrm{e})$. This argument does not seem to directly address the claims made by the art of speaking herself, but is more suited to Phaedrus's original opinion, since the art of speaking did not reject the possession of truth. Nor did she, however, explicitly state that she depends on truth and knowledge; Socrates allowed this ambiguity concerning her status as a transition from Phaedrus's opinion, and now uses the Spartan's objection to supply what will prove to be a crucial premise concerning the nature of art. Possession of the truth is therefore the first criterion demanded of not just the art of speaking, but any art. The Spartan's deliberate contrast of etumos and alētheia provides a second criterion: only an art founded upon what is true simply (alètheia) will be fitting for local custom or practice (one of the senses of etumos). This goes in the reverse direction of Stesichorus' palinode, which rejected the popular story about Helen because it was "not genuine" (243a-b). Here, inasmuch as the practice of an art must lay hold of truth to be art, so too is that truth found in the practices; art will be proven genuine if it bears true fruit. ${ }^{31}$ If, for example, the principal subjects of rhetoric are justice and goodness, the Spartan demands that rhetoric produce what is truly just and good. The story of the sophist Hippias' visit to Sparta is a further illustration of this: the urbane Hippias was not allowed to deliver his usual speeches, but compelled to give "edifying tales" praising the heroes of old because only those speeches would conform

\footnotetext{
${ }^{31}$ Beercroft 57.
} 
with the law. ${ }^{32}$ The relevant question in the Greater Hippias is whether Hippias' speeches make men better concerning excellence or virtue (aretē).$^{33}$ The Spartans, for their part, left that to the law of Lycurgus, which alone spoke with the authority of the truth by which rhetoric becomes genuine. This parochial quality in the Spartan's objection makes a point similar to Socrates' argument that knowledge is confirmed in its use and practice, which can only establish truth if there is some other form of knowledge or persuasion outside of art. ${ }^{34}$ The transition to the arguments refuting the art of speaking is revealing, for Socrates summons these "noble beasts" "to persuade Phaedrus ... that unless he should philosophize sufficiently, he will never be sufficient in speaking about anything" (261a). Given that the context is a refutation of the art of speaking, philosophy is thus set up as the great alternative to artful speech, an artless persuasiveness and proficiency with logos that has arisen out of questioning concerning the grounds of art. Perhaps these "beasts" allude to the horses of the chariot - arguments that arise from the breadth of desires and opinions rather than pure intellection. Without this artless persuasion, an art could never have been learned.

The art of rhetoric "as a whole," Socrates says, is a psychagogia, a leading of the soul, through speeches in any context, whether it be in law courts, in public or private, and on great or small things (261a). The term psychagogia will also be used to describe the power of logos itself, confirming the breadth stated here, and how Phaedrus came to believe that a master rhetorician could speak persuasively on any subject even without knowledge (271c10). If the art of speaking must be founded upon truth, as the Spartan

${ }^{32} H p . M a .285$ d ff.; cf. $R .377 \mathrm{~b}$ ff., 396e 10, $548 \mathrm{e}$.

${ }^{33}$ Hp. Ma. 283c.

${ }^{34}$ The possibility of investigating whether the art of speaking "lies" is necessary for establishing the truth of the claim that it is necessary for all persuasion, otherwise the art would presuppose itself: the artfulness of speaking could only be shown through artful speaking. 
insisted, it would necessarily have knowledge of all that can be expressed in logos. Such comprehensive knowledge would be Zeus-like, the great leader who puts in order all others, and is the patron god of philosophers (246e4-6). Rhetoric and logos partake of the same experiences of the soul, which is led by erös to what is outside of mortal life..$^{35}$

This expansive definition of rhetoric means that the rhetoric used in public settings is only one part of the whole art. There is, Socrates tells Phaedrus, a "private" rhetoric as well. Socrates gives voice to what the three monologues did in deed when they presented a private topic, erōs, in public form (forensic, deliberative, epideictic). That Phaedrus is unaware of this is hardly surprising, given that common practice associated rhetoric exclusively with speaking in courts and assemblies. Private speech was associated with household matters or love matters, but to compare either to rhetoric would sully its name. ${ }^{36}$ Nor would the mention of rhetoric bring to mind other uses of speech, such as in natural philosophy or the other arts. ${ }^{37}$ Socrates' purpose here, though, is not to be crass, but to show the full scope of speech and potential power claimed by rhetoric. In the Gorgias, Socrates coaxes Gorgias himself to extend the art of speech to all these other matters. ${ }^{38}$ That exchange sheds some light on Socrates' purpose here: it forces Gorgias, and now Phaedrus, to consider the power of rhetoric and logos on the

\footnotetext{
${ }^{35}$ Socrates seems to reinterpret Hermes's role of leading shades to the house of Hades as the power of legein and logos; in the Cratylus, Pan son of Hermes is interpreted to mean logos (Hom. Od. 24.1-15, 99$100 ;$ Pl. Cra. 408b-d). The word psychagoggia does not appear until the fifth century, in Aeschylus' Persians, where psychagogos refers to someone who leads shades out of Hades in order to examine them, and in his lost play Psychagōgoi ("Necromancers") (A. Pers. 687; fr. 150-2 [Sommerstein]). Socrates' rhetorician is the psychagogos who leads the soul out of and back into the mortal realm.

${ }^{36}$ On the shamefulness of erotic speeches, see D. 61.1. Kennedy asserts that "love ... was a common rhetorical theme," but can only cite as an example only Demosthenes' Erotikos and Diogenes Laertius' late testimony that Aristotle composed four books on the subject (D. L. 5.1.24) (Kennedy 1963 75).

${ }^{37}$ Socrates' comparison of rhetoric to medicine in the Gorgias is the first step in expanding the scope of the art of speaking ( $449 \mathrm{~d}$ ff.). It is important to note that his illustration of the rhetorician's failure when in competition with a physician does not refute the point that the physician uses speech both with respect to his patient as well as his own study of the nature of body and illness (Grg. 459a-b).

${ }^{38}$ Ibid., $449 \mathrm{~d}$ ff.
} 
individual. If rhetoric really is a leading of souls, should it not be able to produce its effects on both many souls and one soul? And if on one soul, not only on the ignorant soul, but also on the soul that uses, say, speech concerning erōs or medicine, or even on the rhetorician's own soul?

Socrates gives ancient heroes as examples of this hitherto unknown distinction between public and private rhetoric. Nestor and Odysseus, each of whom addressed the Achaean troops, represent the public rhetoric. ${ }^{39}$ Palamedes, the ill-fated hero famed for his invention of other arts, such as the alphabet and arithmetic, represents the private. ${ }^{40}$ These are of little help to Phaedrus, who thinks the examples are merely allusions to contemporary rhetoricians - Nestor is the elder Gorgias, Odysseus is Thrasymachus, and Palamedes is Theodorus ( $261 \mathrm{~b}-\mathrm{c})$. Socrates demurs, for Phaedrus's reading would at the least overlook the significance of Palamedes. Palamedes' inclusion implies that the private rhetoric is the persuasion of oneself or another towards the nature of things, i.e., the achievement of understanding. Both forms of rhetoric, however, if they are to be persuasive, follow the same principle of persuasion. Thus the one who possesses the art of speech will know this principle and be equally proficient in each form. Socrates thus sets the ground for his later argument that public rhetoric will only be mastered if the speaker can master the underlying principle that also governs private rhetoric, from which it follows that he must become an expert in the acquisition of knowledge. In order to demonstrate his artistry, the rhetorician will have to be able to prove, in private, that what he has said publicly was done with knowledge. Socrates' procedure here is

\footnotetext{
${ }^{39}$ E.g., Hom. Il. 2.207 ff., 7.155 ff.

${ }^{40}$ On his invention of number, see A. fr. 252 [Sommerstein], PI. R. 522d. On his invention of the alphabet or "syllables," see E. fr. 578 [Collard and Cropp]. Gorgias gives a longer list that also includes military tactics, writing and written laws, weights and measures, messenger services, and even draughts (Gorg. fr. B1 la.30 [DK]). For further sources, see Woodford.
} 
dialectical, for he has distinguished the private from the public rhetoric in order to reveal their unified principle that would otherwise remain hidden by the outward appearance of skill in public rhetoric.

The basic principle of artful speaking is "speaking the opposite" or antilogic (261c-e). This is seen in forensic arguments, which make a man who seems unjust just or vice-versa, and deliberation in assemblies, which make what seems good bad or viceversa, but also in the writings of the "Eleatic Palamedes," which make "the same things appear to be like and unlike, one and many, at rest and in motion" (261d). The art of speaking therefore lies in the ability to produce contradiction, which it does by making something resemble everything it can possibly resemble, and "bring into light the making of semblances [homoioun] and the hiding of another" (261e). An artful speaker will therefore be able to lead his audience by soliciting their agreement to "many small steps" of such semblances, eventually "crossing over" to the opposite opinion (262a). The importance of the private rhetoric is revealed here: without real knowledge of these semblances, i.e., how things resemble and differ from one another, the rhetorician will not be able "to deceive another but remain un-deceived himself," which would be the case with the "artless knack" that produces effects without clearly understanding how it did so (262a; cf. 260e5). The deception thus comes about because the audience is unable to distinguish the beings themselves from their images or semblances, which are mixtures: "those who hold opinions contrary to what is do so on account of some semblances streaming in" (262b).

Socrates' account of antilogic shows the fundamental role that opposites play in persuasion. This is most evident in the structure or form of persuasion, where the 
argument "crosses over," and the reason for this is a straightforward psychological one: the listener's soul believes one thing and must come to believe other than it, which, at the most basic level is moving from "what is" to "what is not." Without this reversal or turn, the audience's opinion would be unchanged, and persuasion would simply be a reiteration of what was already believed to be the case. For this to be a deception, the listener would of course be unaware that this had transpired and that he holds opposite opinions - there would be no moment of perplexity, aporia, in which the soul perceives a contradiction, e.g., the concurrence of pleasure and pain in the soul that lays hold of beauty, or the beloved who turns to the lover and seems to love what he does not love (251d-e, 255d3; cf. 247a5). The rhetorician is capable, though, of "bringing to light" this state where opposites are made to resemble one another. This seems to be the purpose of the private rhetoric, by which the rhetorician shows himself, or is shown by a teacher, that what seems to be the case (e.g., that the unjust man is just) is in fact not the case. But if antilogic is the singular art "with respect to all that is said," this private rhetoric must also proceed by the same form, and so attaining the knowledge that distinguishes what is from what is not will also entail crossing over from one thing to the opposite (261e). This knowledge is therefore not attained through demonstration, but through the refutation of what it is not, using the semblances or mediating propositions to reject an opinion concerning the nature of the thing. It is therefore through this private use of antilogic that the rhetorician will become able to distinguish in what respects one thing is like and unlike another, and in knowing which ways they are like, be able to make the "semblances" by which he can lead his audience. 
The force of antilogic lies in the principle of non-contradiction and its correlate, unity. The thing in question cannot be the opposite of itself, unlike itself in a fundamental way. In persuasion, the semblance is the means by which a thing comes to be its opposite, and what establishes the contradiction. ${ }^{41}$ When the contradiction is brought to light, e.g., that what was said to be one is many, or that the man who was said to just is unjust, it is these semblances that are of primary interest. The semblance is the third term, the middle term that, being agreed upon as true, allows the conclusion. Where imprecision is allowed with respect to semblances, i.e., in myths or by use of analogy, the speech may easily move to its conclusion. But if the crossing over is brought to light and an aporia experienced, it is this mediating semblance that must be examined in order to understand how the opposite, what is not, came to be and if the contradictory conclusion is in fact true. ${ }^{42}$ The private rhetoric will therefore be concerned with further inquiry into this third term that mediates speech. Just as the parts of true beauty "streamed into" the lover through its earthly "semblance" (homoiotêtos) in the beautiful boy, so too is the "streaming in" of the semblance (homoiotêtos) here the streaming in of assumptions about the nature of things, the ever-present "background" as Ferrari puts it, or the memory of being in its wholeness (cf. $251 \mathrm{~b} 5,253 \mathrm{~b} 8,262 \mathrm{~b} 2-3$ ). ${ }^{43}$ Socrates' palinode, for example, took up the proposition that madness is harmful, which was the semblance that allowed Lysias to conclude that erōs, as a form of mania, is harmful (cf. 235e-236a, 244a).

\footnotetext{
${ }^{41}$ Cf. Ti. 48e-50a, 52a-d.

${ }^{42}$ Two basic results are possible from this experience of opposites: the rejection of the first opinion or premise; or, the rejection of the conclusion, which, having been agreed upon, entails rejecting the premises or semblances by which that conclusion was attained.

${ }^{43}$ Heidegger similarly employs "background" (hintergrund) while interpreting the discussion in the Sophist of the presupposition of being (to einai) (Heidegger $1997 \S 68.327$ ).
} 
Socrates attributes this art to the "Eleatic Palamedes," commonly understood to refer to Zeno, who is depicted by Plato in the Parmenides as doing just what Socrates describes, making the like unlike and the many one. ${ }^{44}$ This allusion helps clarify the assumption of non-contradiction in antilogic and the art of speaking. Although Zeno seemed to bring to light the experience of opposites and contradiction for the sake of “exercise," ${ }^{, 45}$ Socrates' description of Zeno's art attributes to him the same power claimed by rhetoricians and sophists, most notably Gorgias (see 267a-b). Gorgias, in his Encomium of Helen, asserts that all persuasion proceeds by false argument inasmuch as finite words would be other than complete knowledge, which is eternal. From this he concludes that opinion is inherently insecure, and therefore the art of persuasion can impress any opinion upon the soul that it wishes. ${ }^{46}$ Zeno's arguments appear to be similarly destructive of opinion, for he shows that what is many must also be one, and since many cannot be one, the many do not exist; motion is also impossible. ${ }^{47}$ Insofar as both men used contradiction for refutation, they assumed that what in fact is must be by itself and one without change. For Gorgias, this separation of the eternal and what is believed to exist allowed him to assert that there is no being, only appearance, and consequently that the art of speech that rules opinion rules over all. ${ }^{48}$ For Zeno, the negation of all opinion pointed inexorably towards an eternal one or unity that transcends

\footnotetext{
${ }^{44}$ The usual reason for this attribution, that Zeno invented dialectic (Diogenes Laertius, Lives of Eminent Philosophers [D.L.], 8.57, 9.25), seems untenable, for this could as easily be attributed to Parmenides, at least on the evidence of his argumentation in Plato's Parmenides (see Friedländer $3.215 \mathrm{ff}$.). But, as above, which also relies on the evidence of the Parmenides, the power of dialectic is here described in the exact terms of Zeno's treatise.

${ }^{45}$ Prm. 135c8-d7.

${ }^{46}$ Gorg. fr. B11.11, 13; see also B11a.24, 35 [DK].

${ }^{47}$ Prm. 127e; Zeno fr. A25-7, B1-2 [DK]. See also Parmenides' poem, in which he argues that the way of "the opinions of mortals" is without "true reliance" (Parmen. fr. 1.30, 8.50-2 [DK]).

${ }^{48}$ Gorg. fr. B3.67-74 [DK]; PI. Phlb. 58a-b.
} 
the multiplicity of opinion, such that "all is one.",49 Indeed, Socrates had charged that Zeno wrote his antilogical treatises out of love, as a negative support for Parmenides' thesis that only the one is, since he had been the older man's beloved "boy." implied that without this erotic link to Parmenides and the one (or unity), Zeno's public antilogic would have no foundation; it was Zeno's private rhetoric, or acknowledgment that there is a stable basis for knowledge in unified being, that allowed him to escape Gorgias' radical conclusions, and that allows Socrates to attribute to him the art of speaking. ${ }^{51}$ According to his adoption of this "private" rhetoric, the comparison of Zeno to Palamedes is a fitting one. But there is also the matter of the fate of this master of private speaking.

A long tradition reports that Palamedes, despite his intellectual achievements, or perhaps because of them, was betrayed by Odysseus, who accused him of treason and persuaded the Achaeans to execute him. ${ }^{52}$ Palamedes has been remembered as the victim of injustice, but his fate could also be interpreted as the sacrifice of wisdom, or perhaps even the political failure or naiveté of that wisdom. That Gorgias (and many others) saw

${ }^{49}$ Prm. 128a9-bl.

${ }^{50}$ Ibid., 127b, 128a-e.

${ }^{51}$ The argument that Socrates here attributes to Zeno, that "the same things appear to be like and unlike, one and many, at rest and in motion," are the exact words he, in the Parmenides, uses to criticize Zeno's argument as self-evident: if all physical things are mixed, it is "nothing wondrous" that with respect to one attribute, a thing is one, and that in another respect, it is manifold. From this beginning, Socrates postulates that the being of things lies in invisible and non-material forms that transcend all mixture ( $P h d r .261 \mathrm{~d}$; Prm. 128e ff., esp. 129d9-e2). Parmenides later confirms that Socrates' hypothesis, while imperfect, was the proper beginning: "if indeed someone will not allow that the forms of the beings are, looking to all the things [that he allows are] now and other such things, nor defines some one form for each, he will be at a loss, not allowing that an idea of each of the beings is always the same, and thus he will destroy in every way the power of conversation [dialegesthai]" (Prm. 135b-c). In the Theaetetus, Socrates claims that the rhetorician who is devoted to giving an account of himself in private will come to scorn rhetoric (Tht. $177 \mathrm{~b})$.

52 The story of Palamedes' betrayal arises after Homer, and was a common theme in fifth century literature. All three of the great tragedians wrote a Palamedes (A. fr. 96, 97, 252 [Sommerstein]; S. fr. 478-9 [LloydJones]; E. fr. 568, 581, 583 [Collard and Cropp]). See also Gorg. fr. B1 la [DK]; PI. Ap. 41 b; Xen. Apology of Socrates (Ap.) 26, Mem. 4.2.33; Isoc. Busiris (Isoc. 11) 24-30. 
fit to write a defense speech for Palamedes, unable or unwilling to provide effectively for his own defense, is indicative of the latter opinion. ${ }^{53}$ Zeno was also a Palamedes in this sense, for he was tortured and then killed for conspiring to overthrow the tyrant Nearchus, but refused to resort to rhetoric in the fashion of Gorgias in order to exonerate himself. ${ }^{54}$ Socrates of course shares a kinship with these two men, and will, in his own trial, compare himself to the learned Palamedes, being unjustly accused yet nevertheless refusing to speak other than "his customary way" (despite allegedly being offered the services of Lysias). ${ }^{55}$ But the fates of Palamedes and his Eleatic namesake are a warning to Socrates, and suggest a number of political problems in his making the private rhetoric, i.e., knowledge of the beings, the basis of the public rhetoric. Is there a need for a public defense of this private rhetoric, that is to say, the possibility of truth? Could such a defense be effective in the form of private rhetoric, given that public rhetoric is tailored to address "the many"? The fact that Zeno wrote down his defense of Parmenides indicates that there is some need for such a public defense, and that perhaps Zeno was not so innocent of it being "stolen" and distributed. ${ }^{56}$ The form of his public defense, being entirely negative in its argument, and therefore only an oblique or hidden defense (Zeno only reveals this purpose when questioned by Socrates), as well as its spirited origin ("a

\footnotetext{
${ }^{53}$ Gorg. fr. Bl la [DK].

${ }^{54}$ D.L. $9.26-7$

${ }^{55}$ Pl. Ap. 38d-e, 4 lb; Xen. Ap. 26; Cic. De or. 1.54.231; D.L. 5.40-1. Consider a fragment from Euripides' Palamedes: "A fine speech on shameful actions - such wisdom is not worthy of praise" (fr. 583 [Collard and Cropp]). A further dimension of Palamedes' fate is that Odysseus is often cited as having acted out of revenge at the man who disproved his madness to Agamemnon and so forced him to leave Ithaca and join the war against Troy. Here in the Phaedrus, Socrates seems to disprove his own madness and inspiration as he analyzes his speeches.

${ }^{56}$ Prm. 128e.
} 
love of victory from being young"), ${ }^{57}$ will be instructive for understanding Plato's own art of writing and supplement to Socrates' strictly oral teaching.

\section{Lysias and Socrates Examined}

The need for unity that was implicit in Socrates' account of psychagõgia now becomes the explicit theme of his examination of Lysias' speech, as Socrates demands that artful speech manifest unity in its content and form. He and Phaedrus turn to the practice of rhetoric in search of evidence of artful psychagogia because the discussion, Phaedrus notes, "is somewhat bare since we do not have sufficient examples [paradeigmata]" (262c). It is "by some chance," Socrates claims, that "the two speeches that were given have an example of how the one who knows the truth might mislead those listening by playing in words" (262c-d). This is a turning point in the discussion of rhetoric, as Lysias can no longer be considered the principal object of inquiry as stated earlier, but only one example of the real object, the logos itself (see 258d8). The "example," paradeigma, is literally a showing from the side, the revealing of something through indirect means. Phaedrus's expectation as a student of rhetoric is that the knowledge and artfulness that Lysias possessed in order to craft his speech can be made manifest or brought to light in the examination of it. Lysias' knowledge of erōs shapes his rhetoric, and the shape of his rhetoric will reveal that knowledge. ${ }^{58}$ There is no pure deception or esotericism whereby the speaker is completely hidden.

Lysias' skill in the art of speaking (or speech-making to be precise) will be found in how well he is able to lead the soul of the audience from one thing, e.g., giving favors

\footnotetext{
${ }^{57}$ Ibid., $128 \mathrm{~d} 8$.

${ }^{58}$ The phrase "shape of rhetoric" is borrowed from Yunis 2005.
} 
to the lover, to the opposite, e.g., giving favors to the non-lover. Since the basis for artful speaking was established as knowledge of the beings in question as well as their semblances, Socrates will therefore subject the public rhetoric to an examination by private rhetoric. If the ultimate demonstration of a speech's artlessness is its inability to persuade, then Socrates' objections reflect how Lysias has failed to persuade him. What can also be found in these objections are basic criteria for private rhetoric, that is to say, the manner of persuasion that aims at knowledge of the nature of things. The comparison of Lysias' and Socrates' speeches will subsequently allow him to distinguish between artless and artful speaking, and from this a more precise grasp of the art of rhetoric will be attained. The good fortune that they have such examples is attributed to "the gods of the place" and the cicadas, "the interpreters of the Muses," who "may have breathed upon us this gift," rather than any art on Socrates' part (262d). Socrates' comments closely follow the need, mentioned earlier, for techne to be teachable and demonstrable to those who are artless, as Socrates himself professes to be (262d5-6). This accidental or inspired artfulness can only be possible if Socrates participates, not in art, since he says he has "no share in an art of speaking," but in the knowledge that is the basis for art. Otherwise, one could not "chance upon" or discover what otherwise would be unrecognizable and incomprehensible. ${ }^{59}$ This Socratic inspiration and madness that can disclose the nature of art will prove crucial to the relation between philosophy and the art of speaking.

\footnotetext{
${ }^{59}$ Tht. 188a-e, 191d-e, 192d-e.
} 
The examination of Lysias begins with Phaedrus reading out the opening lines, the thesis, of Lysias' speech, ${ }^{60}$ after which "they must say where Lysias misses the mark [hamartanein] and what he does artlessly" (262e). Socrates' first of three arguments is that deception is easier when it concerns disputable terms. The meanings of terms such as "iron" and "silver" are easily agreed upon, while "just" and "good" are greatly disputed (263a). The former terms refer to material objects which, being objects of the senses, are easily indicated, while the latter are immaterial objects only found through discourse and thought ("things of value to souls" [250a]). Although the argument is disputable, for there may be disagreement about what constitutes real iron or silver, or consensus that the just is what is promulgated by law, it is nonetheless the case that the just and the good are subject to a wide variety of opinions and debate, especially in those particular cases that affect the disputants.

Given this disagreement, the rhetorician "must first in some way distinguish and take some mark of each form, both in which it is necessary that the majority wander, and in which [they do] not" and "perceive sharply which of the species it happens to be that he is about to speak on" (263b-c). The rhetorician must be able to precisely divide (as well as collect, e.g., iron into the same form or kind as silver) the objects of his speech with respect to popular consensus, which can only be done by applying a mark or name to represent in speech the beings in question. This theme of logos as marking has a subtle

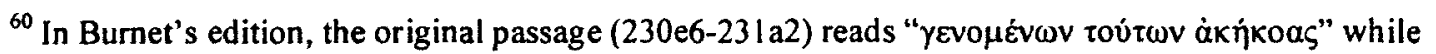

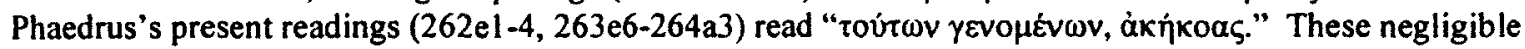
differences in syntax and punctuation have no impact on the meaning of the Greek, and a number of editors consequently bring the passages into conformity (de Vries [see 58n ad loc.] and Yunis in accordance with the latter passages; Rowe preserves the differences). Nonetheless, the differences are conspicuous given that they are lines meant to be read verbatim from a written source, and that Socrates later states that writings can only repeat themselves endlessly ( $275 \mathrm{~d}-\mathrm{e}$ ). If Plato intended these differences, the purpose could be to illustrate how even reading the written word is subject to idiosyncratic variation, either through the error of a scribe or interpretation of syntax, grammar, and style.
} 
presence throughout the Phaedrus, and finds a psychological basis in the palinode, where the erotic soul creates monuments out of the reminders (i.e., the perceptions) of beauty and comes to provisional agreements with itself (and the beloved) concerning the beings (249b-c, 250a-b, 250e-251a, 254b). The "mark" is itself a sensory object that fixes or brings to rest what is in motion. In the present case, it is a sound in speech, or as said in the Theaetetus, "a phantom [eidōlon] of thought in sound," but the mark will also be used to characterize the written word that attempts to fix knowledge in the soul (275a). ${ }^{61}$ If a mark is not made, Socrates implies, the difference will elude the speaker and he will "miss the mark" (hamartanein), as Lysias apparently does. This elusiveness seems to originate from the beings' transcendence of the boundaries set by such reminders and marks. Due to the difference between the beings themselves and their spoken (or written) monuments, a great deal of plasticity may be found in logos and the two senses of legein as "to speak" and "to mean" - the meaning of uttered words will vary according to the opinions of the interlocutors, only taking on a true meaning in light of their shared knowledge of the being itself (the "same-minded" lovers of the palinode $[256 \mathrm{~b} 1]$ ). ${ }^{62}$ This plasticity allows for the "play in words" of the knowledgeable rhetorician, but the rhetorician must nonetheless use a mark to keep distinct in his own mind - the writing on the soul (276a) - the real differences between the types "iron" and "justice," as well as between what actually is and what "the multitude" believes. ${ }^{63}$

\footnotetext{
${ }^{61}$ Theaetetus and Socrates attribute two further definitions to logos, as a "way to the whole through letters," and "some mark by which the thing in question is distinguished from all others" (Tht. 208c).

${ }^{62}$ In the Cratylus, Socrates shows that even the most important word for one who knows, "knowledge" (epistēmē), may admit of different meanings, either the soul being able to follow things in their motion (412a) or that the soul stands still before things (437a).

${ }^{63}$ Alcibiades contrasts Socrates' use of the same terms for the same things to the poets and rhetoricians (Smp. 221e).
} 
Socrates thus reintroduces a part of Phaedrus's definition of rhetoric, that its power lies in its persuasion of the many rather than any individual. The popular opinion that Phaedrus heard about rhetoric is not entirely false, and by reintroducing the effect of rhetoric on the many, Socrates indicates that the distinction between public and private rhetoric, although both are governed by antilogic, is a real one. Still, Socrates insists that the rhetorician's knowledge of what is popularly agreed upon and what is disputable must be manifested in the actual speeches produced for an audience. Socrates uses erōs as an example of something that must be marked as disputable or not. Phaedrus points out that it must be disputable since Socrates was able to say contrary things about it - that "it is harmful to the beloved and the lover, and also the greatest of goods" (263c). Phaedrus does not notice that if indeed the two speeches said completely opposite things (they did not - Socrates only claimed that "such a madness [as erōs] is given by the gods to allow us to achieve the greatest good fortune" [245c]), it follows that he had been deceived by Socrates' two speeches. Lysias, on the other hand, failed to mark what was agreeable and disputable, and was consequently unable to properly lead his audience.

Socrates' second argument concerning artful speaking follows directly from the marking of terms: Lysias did not define or bound (horizesthai) erōs. Socrates elaborates that Lysias, were he to define erōs, would "compel [anangkazein] us to take erōs as a particular one being ... towards which all the rest was arranged" (263d-e). Definition brings what is otherwise contentious into one so that the listener can more easily be led to the desired conclusion by the necessity of non-contradiction. This does not mean, however, that the definition must be true, and Socrates will later admit that his own definition of erōs was not, but only that its clarity and unity are necessary for persuasion 
to proceed (265d). ${ }^{64}$ This is the same argument Socrates made in his first speech when he asserted that without a definition to establish agreement, either with oneself or with others, any deliberation would "miss [hamartanein] everything" (237b7-d3). Socrates then used his definition of erōs to bring about its rejection - thus leading the beloved who was disposed to lovers to the opposite opinion. Whether or not the audience, i.e., Phaedrus, agreed with the definition would be an important qualification of public rhetoric understood as the making of set speeches or monologues, but Socrates will only obliquely address this later. For the moment, he only makes clear to Phaedrus that Lysias did not distinguish in his speech between what is disputable and agreeable, which would have brought his audience into a state of seeming clarity concerning erōs. Socrates consequently claims that his own speeches, because they made use of definition, were more artful than Lysias'. Or rather, "how much more artful you say the Nymphs of Achelous and Pan son of Hermes are than Lysias son of Cephalus with respect to speeches" (263d). Nonetheless, it remains unclear whether definition is necessary or useful as a technique in public persuasion, although it seems to be a necessary part of knowing and distinguishing reality from semblance, i.e., private rhetoric.

Socrates' criticism of Lysias on this point appears to be shallow - why would a speaker define a contentious subject if he intends to mislead the audience by that very contentiousness? Why make something clear when the advantage lies in its ambiguity? ${ }^{65}$ Indeed, Lysias' probabilistic statements about erös depend on his acknowledgment of the possibility that there may exist good lovers, even as he must discredit them as unlikely (231e). But Socrates demands that public rhetoric meet the same stringent criteria for the

\footnotetext{
${ }^{64}$ In the Seventh Letter, Plato similarly stipulates that name and definition are two of five elements of coming to know, but, being only elements, they are by themselves deficient ( $E p .7 .342 \mathrm{a} \mathrm{ff}$.).

${ }^{65}$ Ferrari 1987 46-52.
} 
demonstration of knowledge that is required of private rhetoric. Insofar as only private rhetoric, the refutation of the precise opinions actually held by the individual, is capable of achieving real persuasion by revealing knowledge of what truly is, Socrates' judgment of Lysias' speech is completely sound - the speech cannot claim to be done with art unless it demonstrates that it possesses such knowledge. Yet since Lysias' speech relies on what is likely rather than what is true, it cannot demonstrate such knowledge. Unfortunately for Lysias, he is not here to defend his speech and elaborate on what it says (cf. 275d-e). As such, Socrates does not fail to treat Lysias' speech on its own terms, ${ }^{66}$ since he has shown that, on its own terms, it says nothing true. Perhaps Lysias is artful, but because his writing does not evidence complete knowledge of erōs, he must be considered artless.

Without a definition of erōs, Socrates continues, Lysias is unable to order his speech accordingly, and so cannot bring his audience to the desired conclusion in a definitive and compelling manner. Socrates has Phaedrus read Lysias' opening lines once again, wherein the non-lover declares that the boy "knows my business," but stops the reading a little further on, when it is said that the lovers "repent from doing good, whenever their desire ceases" (263e-264a). Lysias, Socrates says, "[does not begin] from the beginning [archē], but from the end [teleutē], attempting to swim the speech backwards on his back, and begins from the things the lover, having finished, might say to the boy" (264a). Socrates here demands a linear order to speech, rather than, for example, the circularity of the soul's motion, where its perfection or end (telos) was shown to be the return to its beginning (249c6-8). Lysias' disordered speech, by beginning from the end and presupposing a relationship between lover and beloved,

${ }^{66}$ Pace Ferrari 198756. 
parodies how the soul is erotically moved by a prior union with its beloved. Lysias assumes an erotic link to the beloved, but calls it something else in an attempt to realize it. But the soul's journey, if it does proceed through legein and persuasion, entails the turn from one opinion to its opposite, rejecting what seems to be for the sake of what really is, so that its greatest good is not already known to it but must be sought out. The linear order that Socrates demands appears to be a concession to the temporality of human experience, which cannot seek what it knows or believes it already knows. Speech should instead proceed in such a way to attain the greatest clarity concerning what it speaks about.

The need for a definition leads Socrates to his third argument about artful speaking. Without a clear beginning concerning erös, the remainder of Lysias' speech has no integral order:

What about the rest? Do not the [parts] of the speech seem to have been thrown out in a flood? Or does it appear that the second thing he says must have been placed second from some necessity, or any other of the utterances? For it seemed to me, as one who knows nothing, that, not in an ignoble way, the writer said what came to him; but do you have hold of some logographic necessity by which that man placed these things thus beside one another in this order? (264b3-8)

Socrates challenges Phaedrus to find the intent behind writing in this manner. Rather than claim that there was no purpose to this order, as Socrates insinuated, Phaedrus instead claims that he is not "sufficient ... to see through" what Lysias had done (264bc). Not unreasonably, Phaedrus still believes that Lysias did have some purpose in mind; Socrates himself had said earlier that no one could "miss the mark [hamartanein] entirely" (235e). It is impossible to converse in an intelligible way and not touch on something of the truth. But this is also part of the problem of rhetoric, and art generally, for Phaedrus believes that he is able to recognize who is artful, a technikos, even though 
he and Socrates, being amateurs, are unable to assess their work. Lysias' reputation and the pleasing effects of his work have enthralled him. Phaedrus is therefore, like Socrates, in the position of artlessly looking for art. Nonetheless, since he does believe Lysias had a purpose and is artful, Socrates easily elicits agreement that a speech should be ordered like a living animal.

Speeches should be put together like "living animals," with an organized "body" that does not lack any parts and has all these parts arranged "so as to fit one another and the whole" (264c). Speech must aspire to complete unity and comprehensiveness, which is the ultimate demand of private rhetoric that seeks knowledge of unmixed beings. The unity of a speech, however, is not the unity of the being, which is defined as a simple "one" rather than a "whole" with parts. Speech is always composed of parts, a many in the one and multiform, which can readily be seen in every sentence, being composed of subject and predicate, but was also made explicit in the case of antilogic, which binds together a pair of opposites and semblances. ${ }^{67}$ Without these parts, speech ceases to be a whole and ceases to be speech. A singular purpose thus joins and binds together the parts, which are in turn functionally related to the whole. In the terms of the palinode, the analogy of a living animal means a body that moves itself on account of being ensouled (245e4-6). The holism of speech is therefore not simply linear, but also functional. What comes second, third, and fourth follow in their linear order not because of the first (e.g.,

\footnotetext{
${ }^{67}$ The discussion of being in the Sophist suggests that the simplest declarative sentence is itself antilogical and manifold, for "what is" (or "what exists") cannot be understood unless an object - which must be other than the subject - is added to the predicate, forming the opposite, "what is not" (Sph. 244b-245c). The "semblance" in this speech is simply the verb "to be," einai. This is perhaps the most fundamental presupposition or "background" for all speech, and was accordingly identified in the palinode as one of the most fundamental objects of erōs.
} 
the definition of erōs), but for the sake of a greater purpose. ${ }^{68}$ If a speech is able to deduce from an agreed-upon definition or opinion, the full or complete meaning must already be implied in the beginning. But if the analogy of speech to an embodied soul holds, what can be made of the erōs that propels a mortal being on account of its deficiency or separation from the whole of being? Moreover, what can be made of the immortal disembodied soul, which was defined as the self-moving archē of motion, and so was neither simple (the "one" sought by both logismos and Socrates' principle of definition [249b7-c1, 263d7-e1]) nor a whole of parts (its whole was only the sum of two opposites, mover and moved)? Even when Socrates created his "image" of the soul as a winged chariot, were not all its parts - if they were only three - erotically aimed at the superheavenly place? Whatever unity and final necessity is sought by speech or a living animal, that unity appears to exceed the unity or whole of the speech or animal itself. For speech and writing generally, the principles of "logographic necessity" and speech as a living animal have at least three implications: nothing is unnecessary to a piece of writing; everything is ordered to produce the whole; the work is a whole unto itself, comprehensible in the interrelation of its parts. Some provisional rules for inquiry (zètềsis) into speeches can be deduced: study the work as a whole with a singular purpose, rather than a collection of pieces; parts that do not share in a whole are not parts, thus the parts cannot be understood in isolation from the whole ${ }^{69}$ since the whole is composed of parts, the parts must be related to the other parts; seek the reason for the whole through the parts. These rules are not unrelated to the criteria that Socrates has established: distinguish the beings from their semblances; seek the oppositions that form

\footnotetext{
${ }^{68}$ Compare Socrates' first speech. The definition of erōs did not seem to necessitate that he speak of mind, body, associations, property, and pleasures in that order.

${ }^{69}$ Prm. 137c-d; Sph. 244c-245a.
} 
deception and produce persuasion; distinguish words that are agreed upon and disputed; define words. These rules were all of course in evidence in Socrates' examination of Lysias, whose speech, having failed in all respects, is characterized as a dead and therefore unmoving and un-erotic ${ }^{70}$ collection of things that cannot even be called parts since they have no necessary relation to one another.

As a final blow to Lysias' speech, Socrates compares it to the epigraph on the tomb of the famed king Midas. The epigraph is composed of four verses that sing of its own undying testament to Midas:

A bronze-clad maid, I lie still upon Midas' tomb [sēma], So long as water flows and trees grow tall, Remaining on this much-lamented grave, I will tell whoever goes by: Midas is buried within. (264d)

Socrates ridicules Lysias by saying that "there is no difference whether a part of it is spoken first or last" (264e). Since there is no linear order to the verses, the epigraph lacks logographic necessity, and as such is not a whole, but a kind of dead body (recall the play on words in the Gorgias, sōma sēma, "body is a tomb"). ${ }^{71}$ This seems to be the fate of a "mark" or "sign" (sēma)..$^{72}$ But the possibility of rearranging the verses without altering their meaning depends on the epigraph communicating a unified whole, namely the unchanging ("I lie still") and eternal ("so long as...") testament to Midas. Socrates' comparison of Lysias' speech to the epigraph is, on the one hand, a criticism, for the true nature of erōs cannot be discerned without the linear and temporal antilogic. The life of speech is constituted by its motion and temporality, and so it must separate itself from the fixity represented by the bronze-clad maiden. On the other hand, Socrates says that what

\footnotetext{
${ }^{70}$ Burger 79.

${ }_{72}^{71}$ Grg. 493a.

${ }^{72}$ In the Cratylus, Socrates puns on body (sōma) as a "sign [sēma] of soul" (400b-c).
} 
constitutes the whole remains outside of life and death, and is communicated regardless of the strict linear form of artful speech. This qualification of Socrates' principle of "logographic necessity" stems from the eternity expressed in the second verse of the epigraph.

Without the verse, "So long as water flows and trees grow tall," the epigraph could not communicate the immortality of itself and Midas. The verse itself, though, expresses immortality through what is temporal, finite, and linear, i.e., what has a beginning and end: the running rivers and growing trees. Moreover, the epigraph's representation of an eternity that transcends temporal order through its interchangeable verses is Socrates' contrivance; he has removed from the original source two verses that would expand on the second verse's theme of immortality. ${ }^{73}$ These three verses form a continuity that prevents the original epigraph from being rearranged in the manner intended by Socrates. He has violated the original's logographic necessity, understood as linearity, to suit his own end, which is to prove the importance of logographic necessity. Socrates' purpose in the conversation is what has shaped the epigraph, making it whole and bringing life to its dead words. The effect of the reader's investigation is the same, for when the reader reconstitutes the original epigraph in an attempt to find Socrates' purpose, the epigraph makes the same point as Socrates, through the three verses that find the eternal in the enduring cycle of nature. ${ }^{74}$ Examining the original source returns the reader to Socrates' superficial purpose, to emphasize the need for logographic necessity and linear order in speech, but with the additional insight that this logographic necessity

\footnotetext{
${ }^{73}$ Contest between Homer and Hesiod 3.324. Socrates excised the following lines: "and rivers fill, and the sea breaks on the shore, / and while the sun rises and shows its light and the moon as well".

${ }^{74}$ Socrates similarly argued that without the eternal presence of motion, as caused by soul, "the whole heavens and all the earth would come to rest collapsing into one" (245d7-e2). See Chapter III, pp. 131-2.
} 
depends on the writer's intentions, and those intentions depend on his relation to or understanding of the nature of things. Socrates, by qualifying logographic necessity, shows how it is but a phantom, derivative of the eternal necessity, which Socrates called Adrasteia, that binds writer and reader alike.

Socrates thus sets aside Lysias' speech as a negative example of rhetoric, being unable to lead the soul, having neither definitions nor opposites that could reveal the singular nature of erōs, nor an ending necessarily related to the rest of the speech. It was an example of what rhetoric is not, useful in "that someone might profit from by looking at [it], if not by attempting to imitate" (264e). The present discussion is therefore a simple instance of antilogic, leading Phaedrus from the opinion that Lysias is artful, even "the most clever of those now writing," to the opposite, that he is artless (228a). The ugliness of Lysias' rhetoric is made clear in the light of the beauty of truly artful rhetoric. The techniques of artful speaking were the mediating terms, the semblances, of Socrates' argument: distinguishing agreeable and disputable terms; defining the object in question; and giving a logical order to the speech. None of these, though, was absolutely necessary to produce persuasion, at least a temporary persuasion, rather than the final persuasion that private rhetoric aims at. That these techniques alone do not constitute the full nature of rhetoric is shown by the counter-examples, i.e., the examples of artful rhetoric, found in Socrates' two speeches.

The first thing Socrates notes about his two speeches is that "they were opposites," where "one said that favors must be granted to the lover, but the other to the non-lover" (265a). As noted earlier, the two speeches together formed an antilogical movement. Phaedrus, however, misunderstands the role of opposition in speech, saying 
that Socrates had done so "very manfully," as if it were an eristic contest in which the excellence of a man is demonstrated by his power to deceive and persuade without regard for real understanding. Phaedrus does not see the need for the unity to which antilogic tends and is necessary for knowledge. Instead, the speeches, Socrates tells him, were done "madly, which was the very thing I was searching for." The production of two opposing speeches was a kind of madness that distinguished two forms of madness, one "caused by human illness," and "the other coming about by a divine sudden change from our customary ways." As noted earlier, antilogic is used not only to deceive a crowd, but also in the act of knowing and separating the beings. Yet even Socrates' present formation of the antilogic of the two speeches, which together constituted the search for the nature of mania, is now said to be itself a form of madness. It arises out of the same "sudden change" characteristic of erōs - the erotic soul, separated from true being, sought to heal its contradictory state through the search. Therefore the searching erōs is now turned to look at itself as if in a mirror, and must undergo the "sudden change" of divine mania; it becomes moderate and sober in the present analysis in order "to gather into one" its previous experiences (cf. 249c1). The divine mania proves to be the synthesis of what has been called "the dialectic between sobriety and passion" portrayed in the palinode. ${ }^{75}$ The use of opposites for persuasion thus arises from the structure of erōs itself, not for the sake of a manly contest and the prizes to be won from such a contest, but for the sake of apprehending what really is.

The substance of the mania sought by Socrates' speeches indicates that the two speeches were not strictly opposites. They both agreed that "erōs is a kind of mania" (265a6-7; cf. 231d, 235e-236a, 241b-c). This agreement reveals how a "semblance" is

\footnotetext{
${ }^{75}$ Dorter 287.
} 
introduced, for in his desire to go from the rejection of erōs to its acceptance, Socrates used the constant presence of mania to make a plausible transition from Lysias' understanding of erōs. The good erōs was itself found by a second "division," this time of the divine form of madness. Divine mania, Socrates says, was divided according to which god each of its forms belongs to: "the mantic from Apollo, the telestic from Dionysus, the poetic from the Muses, and the fourth from Aphrodite and Eros, which we said was the erotic and best madness" (265b). This is not a perfect recapitulation: Socrates uses the modern term mantikē rather than manike for the first mania. More significantly, but not unrelated, Dionysus had not been associated with the second madness, and his epithet "Bacchus" had been linked to both the poetic and erotic forms of madness (234d5, 245a3, 253a6). Dionysus was a late addition to Olympus, considered a foreign god, and so the exemplary other, a hidden and mysterious external force that now represents well "the divine sudden change from customary ways." ${ }^{, 76}$ In revealing Dionysus to be the god of the second madness, the telestic, the turmoil of the separation from divine grace is explicitly linked to erōs. The erotic madness was of course called "the best" because it produced zêteesis, which encompassed all the other forms of madness, and thereby linked the human being to eternal being.

The clarity of these two divisions with respect to erōs is, however, subject to some reservations. Socrates says that he "expressed by likeness the erotic experience, perhaps on the one hand laying hold of something true, but on the other also being quickly carried another [way], having mixed a not altogether unpersuasive speech, we played a mythic hymn, both fitting and quiet" (265b-c). This is the nature of the semblance, a mixture that must somehow share in the two things it links. It is also the

${ }^{76}$ E.g., E. Ba. $25-35,215-48$; Hdt. 2.49. 
song of the cicadas, which discloses some wisdom so long as one is able to sail past. The palinode did not mislead about erōs simply because it used the likeness of winged chariots, but because speech is itself a likeness. This argument was already woven into the palinode, which contrasted the particular beauties that were only likenesses to beauty itself, which transcended mortal experience and expression. On account of the palinode revealing this relation and therefore its own status as a semblance, Socrates now claims that the "mythical hymn" was "both fitting and quiet [i.e., reverant, euphēmē ] $]^{77}$." Earlier, Socrates had attributed the mythical and poetic form of the speech to the presence of Phaedrus, that is, he adapted the form of the speech to the desires and expectations of his audience (257a, 271e-272a). Socrates thus links the inability of the logos to completely manifest the truth to the necessity that the soul be led. The palinode was so formed in order to disabuse Phaedrus of the opinion about erōs found in the first two speeches. The opposite to which he was led was therefore formed in relation to Phaedrus's first opinion, and was not the truth simply; we miss erōs as it truly is because we must address our present opinions. In order to persuade Phaedrus, Socrates can begin nowhere else but with his opinions. Persuasion and rhetoric can only exist so long as there is a mixing of beings in the semblances, the images and opinions, through which the soul is led; because of this necessary mixing, Socrates' palinode was neither the complete truth nor an "altogether unpersuasive speech." By way of the example of his own speech, Socrates shows Phaedrus how even artless speakers such as himself and Lysias can produce persuasion, albeit imperfectly.

Despite the fact that Socrates has just taught that each speech and definition was false, including the palinode, Phaedrus expresses the pleasure he had at hearing them

${ }^{77}$ LSJ 737. 
(265c). Somehow the experience of the contrariness of the two speeches forms a beautiful whole, but because of the pleasure Phaedrus finds in this, the falsity of selfcontradiction remains a strictly formal or logical concept for him, rather than an experience that compels the soul to seek pure and whole beings. Socrates does not contradict Phaedrus's implicit opinion that the two speeches were together beautiful, and now turns to consider how this beautiful whole was composed so as to encompass these opposites.

\section{Dialectic}

Socrates wants to take up how his speeches "crossed over from censure to praise," which is the "crossing over" of antilogic (262a2). This discussion means that the preceding techniques of definition and logographic necessity were not the basic principles of persuasion and the art of speaking. Yet, "by some good fortune," the two basic "forms of speaking" were found in them (265c). These two forms compose dialectic.

The first form of speaking is "to lead the many scattered things that are seen together into one form, in order that one may, by defining [horizein], make each thing clear concerning what one should ever wish to teach" (265d). This implies that all perceptions can be gathered into a more general kind; this was also called recollection and reasoning in the palinode, and was the impetus behind the demand for definition and logographic necessity (249b-c). The knowledge necessary for artful speech can only be had through this gathering together of manifold perceptions into a unified whole, which was mythically portrayed in the palinode as the "compacting" of the parts of beauty in the 
soul (251e4). Socrates' introduction of teaching as a property of art is therefore not out of place, as the rhetorician must himself be taught or learn the art, through speech of course, if it is to be an art and not simply some natural knack or the divine inspiration that Socrates attributes to his own accidental moments of artistry. The "one" produced by definition, or reasoning, does not, however, constitute the true nature of the object. Socrates' description of the definition of erōs in his first speech is telling: "[with respect to] the things said about erōs, what it is when defined, whether said well or badly, the speech at any rate was able on account of this to say what was clear and agreed with itself" (265d). As noted earlier, the technique of definition alone is insufficient for good speaking, but it provides the clarity needed for the second form of speaking; the monument created by this gathering is only provisional.

The second form is "to be able to cut up again according to form along the natural joints, and to attempt to not break any of the parts, acting in the manner of an inept butcher" (265e). This implies that objects of perception can always be seen under general terms that are subject to division. Where there is no complexity there is no division. The image of the butcher is juxtaposed to the analogy of speech as a living animal; the living speech is now rendered dead, a collection of parts akin to Midas' epigraph. This analysis is the breaking apart of the whole, removing the soul of the speech that makes it self-moving, as opposed to the enlivening efforts of the gathering together. Cutting up and gathering together are complementary in their insufficiency, joined by the desire to grasp precisely the being itself in its true and simple form.

Socrates again turns to his own speeches as an example of this "cutting up" or division. The two speeches together, he says, took "the senseless part of the mind as one 
particular form" and cut it into the left- and right-handed (266a). In the first speech, Socrates says they continued cutting up the left-side of "madness" - here referred to as paranoia, literally "beyond intellection" - until it "found among the parts an erōs ... that it greatly abused with justice." This cutting up was at the time called defining, i.e., what is now said to be part of collection. Nevertheless, in the second speech, in "the parts of madness, we discovered and put forward an erōs homonymous with that other one, but divine, and praised it as the cause of our greatest goods" (266a-b). Each division, then, was not false, but neither was it the complete truth, which could only be comprehended by joining the two forms of erōs as halves. Socrates' speeches thus moved from censure to praise through the proposition that erōs is a form of mania, preserved in all three speeches, and because Lysias had presented a partial account of erōs. Socrates rhetorically led Phaedrus to the opposite in order to prove the negative, that Lysias' definition was not true, but this entailed, as explained earlier, that the new account would also be incomplete. In reconciling these two speeches as part of the same antilogical movement, Socrates' third recapitulation of his speeches produces a holistic account of erōs.

In this recapitulation, erōs, as a division of the "senseless," is a part of mind (dianoia). The division of erös has allowed for a new collection of erōs, which reveals that mind comprehends sense and senselessness. ${ }^{78}$ This is the structure found in the image of the winged chariot, where the charioteer harnessed together the obedient and unruly horses. Mind therefore cannot be equated with a determinate sensibility or rationality, as the non-lover would have it, but is only found by opposing and then transcending the sensibility that presumes to know. This also seems to be the structure of

\footnotetext{
${ }^{78}$ See the diagram in Appendix II: The Three Divisions of Eros.
} 
the soul's ascent as a whole, as it looked beyond the many appearances of being in search of being itself, where alone true knowledge was found. The desires of the unruly horse and the soul's ascent are therefore linked by their disruption of a given sensibility or "mortal good sense" (256e). But if erōs really is madness and outside the ken of sensibility, how can it now be domesticated as a part of mind? Indeed, Socrates' present definition of erōs omits its principal attribute, mentioned in both speeches, that it is a desire for the beautiful; such desire was not just a species of mind, for mind itself and the whole of soul were said to be possessed by himeros (251c-e, 255c). Even the present holistic account of erōs, understood as a division of mind, is incomplete.

Despite the incompleteness of these two forms of speaking, which Socrates names "collection [sunagōgē] and division [diairesis]," he claims that he is "a lover" of them "in order that I am able both to speak and to think" (266b). Together, they are the ability "to look to one and many," i.e., the unity of being found in its many semblances, and whomever possesses this ability "by nature," Socrates will follow "in his footsteps behind him as if he were a god." They work in concert by successively separating the semblances of an object from one another and the object itself, and so compose the complete manifestation of knowledge (266b). Socrates calls the expert of the whole of these two forms "a dialectician," and the art of speaking dialectic. The dialectician will therefore possess the knowledge to perform collection and division perfectly, that is to say, to collect parts into a natural whole, and to separate them according to their natural joints. But the full nature of dialectic seems to elude Socrates, who can only follow the dialectician, and hesitates in naming him (266b). Is "dialectic," from dialegesthai, "to converse," a suitable name for the practice of collection and division as a whole? How 
can it unify and bring into one what are two opposite forms? The whole form towards which collection and division are harnessed is captured by neither, such that the insufficiency of one necessitated a "sudden change" to the other. Dialectic may constitute the perfection of speaking and require the possession of perfect knowledge concerning the truth of the being, but it only indirectly manifests that knowledge by leading the soul to contradiction, and is not that knowledge itself. ${ }^{79}$ Dialectic does not disclose the being itself, and in fact moves forward because of this, for only when one form of speaking has "missed the mark" is the other taken up, either a collection into one when the object appears in many forms (e.g., erōs as a desire for the beautiful and for bodily pleasure), or a division when the defined "one" has encompassed too much or too little (e.g., madness can be beneficial as well as harmful). An erotic analogue to this was seen in the lover who fashioned a monument of his beloved, as if he were a god, only to then be compelled to distinguish the beloved boy from beauty itself.

Socrates' love of dialectic nuances his account of the art, for this love is the same erōs that was said to be a part of mind. On the one hand, dialectic as a whole is necessary for him "to speak and to think" because it is the way by which semblances are differentiated from the being in question. Yet on the other hand, its relationship to the beings themselves, and whether or not it constitutes the true art of speaking, must remain elusive, for the nature of dialectic can only be grasped dialectically. Dialectic requires that it itself remain an open question. ${ }^{80}$ The very discussion with Phaedrus that revealed dialectic was, for example, conducted dialectically, arising out of the assertion that rhetoric does not need knowledge before moving through definition and logographic

\footnotetext{
${ }^{79}$ Parmenides aptly calls dialectic an exercise for the purposes of discovering the truth (Prm. 135c-d).

${ }^{80}$ Gadamer 1989 II.4.3.C.i (359-60).
} 
necessity as elements of the dialectical process, and then culminating in an account of dialectic contrary to Phaedrus's opinion (that knowledge is unnecessary for rhetoric) and Lysias' technique (no definition or logical necessity), yet nonetheless indeterminate with respect to knowledge. Socrates' earlier equivocation whether antilogic really is "one art" neatly expresses this fundamental tension, since any inquiry into the art must put it in relation to what resembles it, and so look at the many in order to clearly differentiate the one form (261e1-2). The question of the art of speaking remains fundamentally open, animated by the need to reconcile it into one. As such, Socrates follows the dialectician longingly, just like Odysseus followed the goddesses Athena and his beloved Calypso (literally, "a concealment," kalupsis), never taking the lead and eventually parting ways in order that he might find what is good for a mortal. ${ }^{81}$ Though antilogic and dialectic clarify the opinions, they only reveal the nature of being through the opposition of opinions, i.e., the opposition of what is said to be and what is not. Since the true nature of being remains hidden in the "background," erös sets in motion the mind and its dialectical search. ${ }^{82}$ It is from this apex concerning the basic forms of speaking that Socrates must divide dialectic from itself and descend back down to Lysias and the conventional practice of rhetoric, searching for these forms through their images. ${ }^{83}$ When he asks Phaedrus, "is this that art of speaking by which Thrasymachus and the others have come to be wise with respect to speaking?", their search begins anew.

\footnotetext{
${ }^{81}$ Hom. Od. 2.406, 3.30, 5.193, 7.38; see also 5.192-226 on Odysseus' longing for home.

${ }^{82}$ Faced with contradiction, "when the eye of the soul is sunk in the barbaric mire, dialectic gently draws it forth and leads it up" (R. 533c-d).

${ }^{83}$ R. $511 \mathrm{~b} 7-\mathrm{c} 2$.
} 


\section{On Technique}

When Socrates asks Phaedrus whether the rhetoricians and his friend Lysias have this art of dialectic, Phaedrus is surprised, and says that they do not. He therefore says that they do not have the art of speaking; but Phaedrus only says this because he has become lost along the way, and he tells Socrates that "the form of rhetoric somehow eludes us" (266c). For Phaedrus, what Socrates presented has no resemblance to rhetoric as he, Lysias, and the majority, conceive it. Phaedrus presumes, not unreasonably, that he has some knowledge of what rhetoric is because of his experience with its actual practice, which he believes has been conducted successfully without the abstruse considerations of dialectical inquiry. If dialectic is indeed the true art of speaking, Socrates must show Phaedrus how it is manifested in wider practice. In order to do so, Socrates must further distinguish Phaedrus's rather obscure opinion about rhetoric before it can be collected back together with dialectic: "what particular thing of rhetoric," he asks, "is being left behind?" (266d).

What has been left behind, Phaedrus states, are those many techniques written down in the manuals of rhetoric. "A beautiful reminder," Socrates says, as if Phaedrus were the black horse reminding the charioteer to return to earthly beauty $(266 \mathrm{~d} 7$; cf. 254d2-7). The techniques that are written down are themselves called "many beautiful things" - perhaps mere reminders rather than the truth itself (266d7). The problem Phaedrus poses to Socrates is whether or not these techniques can be considered the art of rhetoric simply, and if not, what does the art consist of beyond its techniques? If dialectic really is the art of speaking, it should be able to account for those things regarded to be a part of it, either by rejecting them or reconciling them to itself. 
Socrates mentions to Phaedrus twenty-six rhetorical techniques, taking a playful and mocking tone yet nonetheless displaying a broad reading of the subject matter. To begin, there are five techniques that are not attributed to any particular rhetorician and are apparently quite obvious parts of rhetoric and speech. These natural techniques include: a "preamble"; "exposition and testimonies"; "proofs"; "probabilities" (eikota); and a "recapitulation" (266d-e, 267d). The preamble was earlier mentioned as a part of legislation, which served to link the speech to its audience and so give it purpose (258a). After the exposition, the following three techniques are devoted to its demonstration, each relying on different criteria: testimonies rely on authority; proofs on argument; and probabilities on what is likely. The inclusion of all three techniques indicates the insufficiency of each, and so testimonies must be substantiated by proofs, and proofs in turn by probabilities. That probabilities would follow on necessary arguments admits either that the audience as a whole is unable to follow those arguments perfectly, or that the object cannot be established with the strict certainty of necessary argumentation. The "recapitulation" is described as "the end [telos] of speeches," that serves "to remind those listening about what has been said," thus usefully encapsulating the manifold speech (267d). These six natural techniques seem to encapsulate the full range of a speech, from beginning to end, providing the linear order and the bringing of parts into necessary relation as demanded by logographic necessity. ${ }^{84}$

The remainder of the techniques are attributed to nine rhetoricians. The first is Theodorus, whose techniques, "confirmation" and "further confirmation," and "refutation" and "further refutation," supplement the proofs' aim to produce a coherent linear order so as to evidence unity in speech (266e). They are contraries, encompassing

\footnotetext{
${ }^{84}$ Aristotle reduces these to simply four: preamble, statement, argument, and epilogue (Rh. 3.13).
} 
the movement between opposites seen in antilogic. Perhaps it is because of this professed power to persuade in opposite directions that Phaedrus associated him with the wily Odysseus (261c). Socrates also calls Theodorus a "Daedalus of words," referring to the inventor who was said to have made moving statues, and whom he often invokes as an analogy for the motions of logos. ${ }^{85}$ Aristotle describes Theodorus' use of contraries and paradoxes as useful for producing learning by going against the audience's expectations and turning them to the opposite. His techniques are nonetheless redundancies that hide this principle of persuasion, for a refutation of others confirms one's own argument, and a confirmation refutes the others'; the two techniques are simply part of "proofs." 86 The techniques of the second rhetorician, Evenus, who is also a poet, are striking examples of the deception and semblances that are part of antilogic: "covert allusion"; "indirect praise"; "indirect censure" (267a). ${ }^{87}$ The latter two indirections are simply derivative of Evenus' first technique, but what is interesting about each of them is how they produce two messages or even two lines of argument in a speech, the superficial one that is accepted by the audience and the one that is hidden because it would not be immediately persuasive. Such a technique is, though, of little use unless the audience is composed of more than one person, each receiving different messages, or the speech is written down to allow for review. This seems to be why Socrates says these indirections are "an aid to memory," for an attentive listener or reader, who sees what is alluded to and notes the deception, is reminded why it was necessary to hide the allusion, praise, or censure. The opposites used in antilogic, for

\footnotetext{
${ }^{85}$ See Pl. Euthphr. 11b-e, 15b, Men. 97d-e. There is a later story that Daedalus made wings that lifted him from imprisonment, a power that Socrates also attributes to the logos as a means of perceiving true being (Ovid, Metamorphoses 183-259; Hyginus, Fabulus [Hyg. Fab.] 40).

${ }^{86}$ Arist. Rh. $1412 \mathrm{a} 19,1414 \mathrm{~b} 7-19$.

${ }^{87}$ Phd. 60d. Socrates says that Evenus is a philosopher (Phd. 61c). Evenus also taught virtue (Ap. 20a-c).
} 
example, could not be said to express the simple non-contradictory truth that gave force to the reversal of opinions.

The following set of techniques are attributed to Teisias, said to be Lysias' teacher in rhetoric, ${ }^{88}$ and Gorgias. Their contributions are "that the likely things [ta eikota] are to be more honored before the true," and "to make small things appear large" and the large small, and the old new and the new old, and, finally, "conciseness and unlimited length of speech concerning everything" (267a-b). The deliberate movement between opposites is the application of the basic principle of antilogic (to make "the same things appear to be like and unlike, one and many, at rest and in motion" [261d]), and their use of likelihood an easy means to affecting that opposition, by casting doubt on the absolute certainty of a proposition. Socrates later gives the example of a strong man who is unlikely to have been assaulted by a weaker man alone $(273 b-c)$. It is unclear whether this technique of probability is distinct from the natural technique mentioned earlier, but Socrates will later claim that Teisias' whole "art" was based on the use of probability, rather than being one of several parts of a speech.

Socrates' mocking reaches a peak when he juxtaposes Gorgias' "speaking both with conciseness and at limitless length" with Prodicus' rejoinder, to give speeches that are "neither long nor short," but "fitting" (metrios) (267b). Prodicus' place in this list is thus a curious one, for he appears to share Socrates' sentiments about the nature of these rhetorical techniques, with his "fitting" a playfully crucial but vague formulation that resonates with the presupposition of unity and demand of logographic necessity found in antilogic. That Hippias is then said to agree with this good sense is a not insignificant joke in its own right, given Socrates' interest in the relation between erōs and the

${ }^{88}$ Pseudo-Plutarch, Lives of Ten Orators 3. 
beautiful. In another conversation with Socrates, the sophist had claimed that "whatever is fitting [prepein] for each thing, this makes each beautiful," only to be compelled to contradict himself. ${ }^{89}$ Nonetheless, Prodicus' "fitting" is prophetic for Socrates' demonstration that dialectic really is the essence of the art of speaking with which Phaedrus is enamored. The "fitting" will prove to be the crucial but elsuive part of knowledge upon which dialectic depends for its perfection.

The seventh rhetorician is Polus, whose techniques, "speaking with reduplication," "speaking with maxims," and "speaking with images [eikonologia]," are forms of semblance (267c).$^{90}$ For Protagoras, the eighth rhetorician and rival in fame to Gorgias, to follow this is another joke, since his signature technique is said to be "correctness of diction." This is derivative of the principles of "making a mark" and defining that Socrates identified as necessary for establishing a clear movement in speech from one thing to its opposite. That this technique is here mocked is at first surprising, but upon further consideration, it serves to remind Phaedrus that Socrates qualified definition - although it clarifies an opinion, it can be "spoken well or badly." But Protagoras" "correctness of diction" cannot be thought to imply any strict correspondence between speech and being, as indicated elsewhere when Socrates interprets Protagoras' thought as radically Heraclitean. ${ }^{91}$ Rather, Protagoras' technique is strictly rhetorical, an instrument for affecting that the simple truth can be manifested in words without semblance, which is to say, without refutation and dialectical exercise. The irony is that

\footnotetext{
${ }^{89}$ Hp. Ma. 290d, 293d-294e.

${ }^{90}$ E.g., Grg. $473 \mathrm{c}-\mathrm{d}$.

${ }^{91}$ Socrates attributes to Protagoras, on account of his argument that knowledge is perception, a radical Heraclitean doctrine that being is unending change (Tht. 179c ff.). The corresponding account of logos and names is found in the mouth of Cratylus, who cannot consistently maintain that all names have a natural basis (Cra. 428d-429c, 434a-435e).
} 
such a pure manifestation is, according to Socrates, impossible, for it must already begin with and be established through incorrect diction. For example, if one were to say that erōs, correctly speaking, is the desire to achieve perfect unity through the mind's contemplation of being, this would have to be first distinguished from the conventional usage of erōs expressed in the urbane speeches, that it is the desire for bodily pleasure, yet still reconciled as to why the same word has been used for two apparently different phenomena. Detached from this dialectic, "correctness of diction" would be mere declaration or legislation, divorced from the opinions of the audience and so unpersuasive. Socrates' ridicule of correct diction helps clarify how it is that logos actually persuades. It is closely related to how writing may serve as a reminder, taken up in the later discussion of writing.

The ninth rhetorician, not incidentally the rank numbering of the tyrant, is Thrasymachus (cf. 248e). His techniques include: "the wailing speeches of old age and poverty that are dragged out" (e.g., in courtroom pleading); "rousing the many to anger at the same time, and again when they are angered 'singing incantations to charm [them];"' and "to cast as well as destroy slanders" (267c-d). The alternate arousal and calming of the audience places the hitherto coolly rational antilogic in the context of the passions associated with the lower parts of the soul, the horses rather than the charioteer. These are not incidentally also the first techniques to expressly identify the audience as "the many" and to manipulate their passions. This dimension of rhetoric is not greatly explored in the present discussion, although it has been close at hand throughout the Phaedrus in the madness of erōs, the shame of the white horse, the blind fury of the black horse, the fear of the pains of the whip and love, and the jealous rage of the lovers who 
follow Ares. Each of these were incited by the separation of the soul from its beloved, whether it was honor, the beautiful boy, or the joys of pleasure and freedom from pain unlike the cicadas, Thrasymachus" "song" is not content to simply please. These techniques give a forceful demonstration of how the deception, the turn, that is affected by rhetoric is closely related to the fundamental experience of erōs as a separation from being, and how that experience is manifested in what might be called irrational, or perhaps non-intellectual, symptoms. The "strength" that rhetoric possesses with the many thus derives not from that part of the soul that is "more complex and Typhonic than Typhon" on account of which the soul is divided with itself and becomes disordered $(230 a, 268 a)$. It is from this link between "the many" and the disorderly passions that primarily arise from the body that the tyrant becomes visible, not simply as the capricious rule of a single man, but as a psychological state of disorder and forgetfulness of the simplicity of true being. The "wailing speeches" by which a defendant would persuade a jury to suspend his just punishment would be one Socratic example of how the many would use speech in the manner of a tyrant. ${ }^{92}$ In light of this, the disorderliness of Lysias' speech could be seen as a mirror to the many whom a written speech must address, not as a celebration but rather a demonstration of the disorder of the left-handed erōs. Thrasymachus, however, seems to have mastered his technique sufficiently enough to precisely lead his audiences from a state of tumult to its opposite and vice-versa - the challenge before him is not to evoke the passions in a crude way, but to possess a knowledge of the subtle gradation of semblances that would allow this passionate reversal.

\footnotetext{
${ }^{92}$ Grg. 475e ff.
} 
The tone of Socrates' presentation of these techniques suggests that they obfuscate rather than clarify, contrary to the techniques introduced by Socrates, such as naming, definition, logographic necessity, collection, and division. Nonetheless, Plato has Socrates use all of the rhetoricians' techniques over the course of the dialogue, not least of all Polus's "speaking with images" in the palinode (267c). The number of ways that antilogic and dialectic are reduplicated have already been mentioned, and Socrates has even "indirectly praised" Prodicus, if not all of the rhetoricians whose techniques he has shared in..$^{93}$ The only ones that Socrates does not seem to have used are Teisias' and Gorgias' probabilistic arguments (his use of images is the inverse, the use of the improbable), and Thrasymachus' techniques that are performed before crowds. Socrates' playful aggravation of Phaedrus earlier in the dialogue, who is of course alone, is the exception that proves the rule $(235 \mathrm{c}, 236 \mathrm{c}-\mathrm{d})$. The qualified use he will make of "the wailing speeches" in his own defense speech confirms he is not unaware of the power and efficacy of such techniques. ${ }^{94}$ The exception of these two techniques will later prove significant when considering the full nature of Socrates' art.

With Phaedrus's understanding of rhetoric now clarified as the mastery of techniques, Socrates proposes that they "look more closely at these things under the light, and [see] what power of the art they hold" (268a). Phaedrus's rejoinder, that it is "a very

\footnotetext{
${ }^{93}$ A few further examples are sufficient. Socrates' clearly structured first speech includes a "preamble" in which he summons the Muses and begins a myth about the non-lover's secret love, an "exposition" in which he describes the principles of deliberation and his definition of erōs, "testimonies" in which he appeals to "what is clear to all," and "proofs" in his examples of how the lover harms the boy (237a-d, $238 \mathrm{~d}$ ff.). One "covert allusion" in the palinode has already been discussed: equating logismos to "recollection," then relating recollection to erōs, and then erōs to searching, links logismos and the search, although the link between logismos and erōs is never made explicit. The making great the small and small the great was seen in the collection and division of beauty and its "parts" (25lc-e).

${ }^{94}$ Socrates denounces the "wailing speeches" of those who bring their tearful family members into court to evoke the pity of the jurors, yet nevertheless mentions his poverty and the plight of his wife and young sons (Ap. 31c, 34b-35b). On Socrates' use of rhetorical techniques in his Apology, see Seeskin 59.
} 
strong [power], Socrates, in a large gathering," is conceded by Socrates, and he will later consider its efficacy and potential for abuse in the context of Teisias' probabilistic forensic rhetoric. For now, he presses on to the basic question as to whether technique is a sufficient mark of artfulness, which it is not, as "there seems to be a gap in their warp." Simply put, the rhetoricians who have written down these techniques have described their art artlessly, unable to weave a logos concerning the art of speaking. This difficulty, Socrates will argue, is peculiar to the art of rhetoric. Socrates thus attempts to gather this understanding of the art of rhetoric as technique together with other arts so as to properly distinguish it. The method here is dialectical, refuting the opinion that technique is sufficient for art on the basis of what has been agreed to be artful.

Socrates chooses arts that are familiar and dear to Phaedrus: medicine; poetry; and then a return to rhetoric. In each case, he asks acknowledged masters of the art whether the memorization and application of techniques is the whole of the art. He begins with medicine as the model art and the most familiar to Phaedrus, with respect to the apparent self-evidence of the ends of medicine as well as his long friendship with the physicians Eryximachus and his father Acumenus. What would these men reply to someone, Socrates asks, who came before them and said:

I know how to apply such things to the bodies, so as to both warm and cool them if I wish, and if it seems best to me, to make them vomit, and again if [it seems best to me], to make their bowels move, and many other such things; and knowing these things, I am a worthy physician and [am able] to make another to whom I pass on knowledge of these things. (268a-b)

Socrates here chooses as examples of effects those that he metaphorically attributed to the ecstatic soul that alternately beheld and was separated from beauty, in which the case their utility depended entirely on whether the soul perceived true beauty; if ecstasy 
should be induced for an image of beauty rather than beauty itself, moderation and a cooling would be more prudent (251a-252a, 254b). The case of the body is similarly complicated. Phaedrus scoffs at the pretensions of the amateur physician, emphatically saying that Eryximachus and Acumenus would think him "mad" to believe he was a doctor simply because he "had heard somewhere from a book or chanced upon some trifling drugs [pharmakia, diminutive of pharmaka]" (268c). Rather, the physician must "also know for whom and when it is necessary to do each of these things, and to what extent." Socrates has chosen this first example well.

This presentation of the medical art does, though, raise a few questions. Is this how Eryximachus understood his own art? How is the question of "for whom," "when," and "extent," determined? To what does medicine aim? As to the first question, Eryximachus' speech in the Symposium is instructive. It affirms the argument that medicine is more than the application of techniques, for it has the purpose of establishing a "harmony" between contrary states in the body, rather than simply producing changes. 95 The medical art culminates in knowledge of the good and bad loves of the body, how they arise in nature as a whole (e.g., in different seasons), and how to procure the one without the other in order to establish the harmonious state. The aim of this harmony in the body is not simple healthiness, however, but to allow for the enjoyment of the pleasures of both the "good" and "bad" loves when they would otherwise be "out of season" (akairos). Eryximachus' highest aim is the continual experience of pleasure through the artful and moderate application of the two loves, without obstruction by the body - the same end that Phaedrus said was that for the sake of which one lives, which he

${ }^{95}$ Smp. 186c-187b, 188a-d. 
pursued in rhetoric (258e) ${ }^{96}$ Thus the end of the medical art becomes open to the question, bodily health for the sake of what? In the Republic, Socrates raised this issue in terms of the relation of medicine and poetry to the city, which subordinated all the arts to its needs. Should a physician treat the body of a man whose soul is corrupted or is useless to the city? There, Socrates approved of Asclepius as a "politic" physician. ${ }^{97}$ In fact, this question was already implicit at the outset of the Phaedrus, which contrasted the "noble" Acumenus to the ignoble Herodicus, who devised his regimens out of an obsessive fear of death (227a, d). Given that medicine admits of different uses, the use of the body itself cannot be reduced to its preservation; it is only a part of the greater whole of the "living animal."

In his second comparison, Socrates turns to poetry, which is represented by the celebrated tragedians Sophocles and Euripides. In poetry's use of speech, there is a closer resemblance to rhetoric than medicine, which allows it to act as a midpoint in Socrates' refutation of the belief that art is simply a collection of techniques. Indeed, Socrates has an amateur poet present to the two masters expressly rhetorical techniques "making long utterances on small things and very short ones on great things, piteous speeches whenever he wished, and the opposite, frightening and threatening ones" - as evidence of his capacity to make tragedies and teach others the same (268c). These were the techniques of Gorgias and Thrasymachus. Thrasymachus' techniques were expressly suited to crowds, while Gorgias was also noted for his influence on poetry. ${ }^{98}$ As with the comparison to medicine, Socrates also identifies teaching to be an important criterion for

\footnotetext{
${ }^{96}$ Ibid., 187d-e, 188d. Compare Socrates' argument that medicine arises and develops out of the desires for luxury that produce a "feverish city" $(R .372 \mathrm{~d}-373 \mathrm{~d})$.

${ }^{97} R$. $407 \mathrm{c}$-e. Also see $L \mathrm{~g}$. $728 \mathrm{~d}$-e on the political determination of bodily excellence.

${ }^{98}$ Smp. $198 \mathrm{c}$.
} 
art. But this transition from the use of drugs on the body to the use of speeches on the soul contains more than a mere repetition of the example of medicine.

Phaedrus sees immediately that the error of the amateur poet is the error made by Lysias, that he does not know the proper "arrangement" of these techniques "so as to fit one another and the whole" - a verbatim quotation of Socrates' principle of logographic necessity (268d; cf. 264c5). What, though, is this "whole"? Does it mean that the whole of a living animal, composed of parts joined by soul, is the poem itself? Socrates says that the purpose of poetry is not simply to produce "the highest and lowest notes on a string," but to produce poems that harmonize these notes. Given that the techniques mentioned refer to the effects on the audience, the object of poetry cannot simply be the poem, but the soul of the audience as well, just as the object of medicine was not the drug, but the body. The principle of logographic necessity, as discussed earlier, cannot therefore be understood in isolation from its use, so that there is no proper arrangement of a speech or poem without knowledge of how it effects the soul. Socrates thus compels the poet to lay claim to knowledge, rather than the earlier mad inspiration of the poet who "educates future generations" (245a). This resumes the contest with poetry over the education of Greece, most fully explored in book ten of the Republic, where the good poet is also compelled to lay hold of knowledge. There, poetry's end is said to be imitation rather than harmony, but the difference is not so great when the ultimate object of imitation is understood as the idea, the "form" itself, whereas in the Phaedrus the superheavenly place where true being resides is said to be the source of what is fitting for and productive of harmony in the soul $(247 \mathrm{~d}) .{ }^{99}$ The poets, though, only imitate the heroes, "glorifying the myriad deeds of the ancients," without any demonstration of

\footnotetext{
${ }^{99}$ R. 597b-e.
} 
whether these are truly good or bad models for their students $(245 \mathrm{a}){ }^{100}$ Without knowledge of what is truly good, the poet takes advantage of the confusions in the lower parts of the soul, as Thrasymachus does, that believe something can be the opposite with respect to the same thing, and so is particularly effective with the ignorant. ${ }^{101}$ The poetic display seems to resolve these contradictory states in a gratifying whole. ${ }^{102}$ In this attention to pleasure, such poetry "fosters waters that should be dried up," in contrast to the streams that were portrayed in the palinode as being poured upon the soul that pursues beauty (251c-d, 253a-b, 255b-c). ${ }^{103}$ If the "harmony" to which Socrates says the art of poetry aims is understood as solely within the poem itself, on its own terms as it were, the poet would lose sight of his principal object, the soul that experiences the pleasures of speech and music and judges the harmony to be good or bad - and so lose sight of the highest harmony (cf. $277 \mathrm{~b}-\mathrm{c}$ ). Perhaps this is why Socrates subtly inserts "the musical man" to demonstrate harmony, rather than the tragedians (268d6-e6). Rather than abuse the amateur for his ignorance, as Phaedrus does the amateur physician, "the musical man" - the mousikos Socrates claims Phaedrus is - would speak "gently" when telling him that he only "knew the things to be learned before harmony, but not harmonics" (268d-e). The mousikos thus produces harmony in his student and, conducting himself harmoniously, is harmonious himself.

In his return to the art of rhetoric, the exemplary rhetoricians that Socrates identifies are Pericles and "the honey-voiced Adrastus," the ancient king of Argos

\footnotetext{
${ }^{100}$ Ibid., 599 d-e.

${ }^{101}$ Ibid., 602c-603b, 605b-c.

${ }^{102}$ The tragic poem gratifies "a natural desire for lament" $(R .605 \mathrm{a})$. The pleasing effect of the tragedy indicates how its express discordance must be resolved or harmonized into a unity, and so admits the priority of the latter. Take, for example, the resolution of Oedipus' pain and despair into the immutable Fate of the cosmos (S. OT 1524-30). Aristotle describes this effect as the "catharsis" or "cleansing" (Poetics 1449b27-8).

${ }^{103}$ R. 606d.
} 
(269a). ${ }^{104}$ This turn to statesmen is a return to the most public use of speech and most public of arts, ascending from the privacy of the body and poetry that serves private as well as public purposes. Rather than the indeterminate ends of the rhetoricians mentioned earlier, the statesmen must concern themselves with the preservation of the city as a whole, and thus to the objects of both previous arts, the preservation of the body and the harmonizing of the citizens (cf. 239c-d). Like the musical man, the statesmen will be more urbane in rebuking "those who have written these things [rhetorical techniques] and teach them as a rhetorical art" than were the "rustic" Phaedrus and Socrates, who sharply point out his ignorance (269a-b). The statesmen who follow this gentler course are said to be "wiser" - not yet an ironic statement, since their advice here is correct, that sophistication and gentle words of instruction are necessary to persuade those who have come to believe themselves experts. "One must not be harsh but forgiving," Pericles says,

if some people who do not know dialectic prove unable to define what rhetoric is, and from this experience of having the things that must be learned before the art believe [themselves] to have discovered rhetoric, [and] that when they teach these things to others they have taught rhetoric completely (teleoss), and as for each of them [the students] speaking persuasively and arranging the whole, since it is no work at all, they must furnish [this] in their speeches from their own learning. (269b-c)

Socrates' great irony is to put these words in the mouth of Pericles, whose own knowledge of dialectic, and therefore rhetoric, will be cast in serious doubt. It is through dialectic that the rhetorician will be able to give an account of his art as it truly is and so perfect it, as Socrates and Phaedrus are attempting to do in their own conversation, alternately collecting and dividing the principles and practices in order to clearly distinguish "the rhetorical form" itself. Here, the nature of rhetoric is outlined as the

${ }^{104}$ Hom. Il. 2.572; Pi. Nemean Odes 9.30; Hdt. 5.67. 
combination of the advice of the physicians and poets, including the knowledge of both "for whom and when ... and to what extent" to use rhetorical techniques and how they are to be arranged as parts of the whole of a speech. "The whole" to which rhetoric aims is thus both the linear and functional forms of logographic necessity, which can only be understood in relation to the soul that must be persuaded. The object of rhetoric has now doubled to include both the speech and the soul. Without such knowledge, there is neither an art of rhetoric nor the possibility of it being taught. This contradicts the claims of a rhetorician like Gorgias, who would teach students how to speak in a law court without teaching them what justice is, ${ }^{105}$ even though he believes there is no clear connection between "speaking persuasively and arranging the whole" and knowing the subject matter of the speech. Socrates himself supplied this connection in his earlier stipulation that a rhetorician must know the difference between a semblance and the being of what he wishes to speak about. ${ }^{106}$

Phaedrus now claims to be persuaded that the art of rhetoric does not consist merely of technique, and that a rhetorician must also possess dialectic and knowledge of the whole - how a speech is formed in relation to its audience. But since he has just now learned of the existence of dialectic, and since the rhetoricians do not seem to teach it, he is right to ask Socrates, "how might someone be able to acquire for himself the art of the real rhetorician and persuasive man?" (269c-d). Socrates gives three basic criteria for becoming a perfect rhetorician: a suitable "nature"; "knowledge" (epistēmē); "and practice" (269d). Such a man would be "a complete competitor," in contrast to the

${ }^{105}$ Grg. 456a-457c, 460c-d; cf. Men. 95c, Phlb. 58c.

${ }^{106}$ Aristotle similarly argues that politicians should devote themselves to studying and writing about political science rather than writing the speeches that they do in law courts or assemblies (EN 1180b351181a13). 
current popular form of the art, "but with regard to so much of it as is art, the way

[methodos] appears to be, it seems to me, not [the way] by which Lysias and

Thrasymachus travel." 107 The true way of rhetoric is thus disclosed through the

refutation of the conventional way of rhetoric that uses techniques according to the whim of the rhetorician, that is, without knowledge (epistèmē) of the soul; the way that travels under the heavens, as it were, is perceived through dialectic, but therefore only dimly, by negation (cf. poureia, 256d). To call this hidden way a "method" would therefore assume too much, ${ }^{108}$ but the present clearing of the way is the first step in acquiring the art of the real rhetorician.

\section{The Noble Rhetoric}

Socrates once again begins his inquiry into the art of rhetoric by beginning from a commonly held opinion. In an apparent reversal of what is said in the Gorgias, Socrates claims that Pericles "likely proved to be the most complete of all in rhetoric," having accomplished the joining of rhetoric with the study of nature (269e). Although Pericles was of course widely celebrated by this time, ${ }^{109}$ Socrates' favoring of him over so famous a rhetorician as Gorgias indicates the importance he attaches to the political functions of rhetoric, particularly in the actual leadership of the city. Socrates alludes here to a political art that must also take up the study of nature for its perfection, alongside the

\footnotetext{
${ }^{107}$ Griswold observes that Socrates and Phaedrus only take up "that which has to do with art," implying that the whole of rhetoric may be greater than art alone (Griswold 1986 189). This is discussed later in the context of Teisias' "practical" objection to Socrates' dialectical rhetoric.

${ }^{108}$ The refutation of art as technique qualifies any conception of "method" as a set of procedures, rules, or techniques of inquiry, for such a method must presuppose a determinate end that justifies the use of these techniques in their specified manner. That is to say, a determined method presupposes the nature of the object and that the method is the necessary manner of disclosing that nature. As discussed earlier, the basis or principle of dialectic is fundamentally problematic. By which method is method established?

${ }^{109}$ Thucydides testifies to his immense reputation for leadership and rhetorical skill (Th. 2.65.8), an opinion that Plato's characters frequently echo (see sources in Nails 223).
} 
mastery of rhetoric. ${ }^{110}$ In fact, "all such great arts need in addition babbling and lofty talk concerning nature, for in all things this high-mindedness and perfect workmanship [telesiourgos] seems to come from such a place" (269e4-270a3). The ends of these arts, as suggested by the examples of medicine and poetry, must be placed not only in relation to the nature of their objects, but to the natural use of those objects. Only a study of nature as a whole can provide this comprehensive view. Socrates makes this claim, however, in a mocking tone, adopting popular terms of disparagement for the study of nature, and so mimicking the ridicule that Aristophanes leveled at him as one who studied "the things aloft and below the earth." " But he is not simply sardonic, since purported knowledge of nature that amounts to no more than chatter will be of no help to the true and noble rhetorician.

Pericles, for his part, "was filled with this lofty talk" by associating with Anaxagoras, whose natural philosophy taught "the nature of mind and mindlessness [lit. intellect and lack of intellect, nous te kai anoia]" (270a). ${ }^{112}$ The opinion that Pericles was "the most complete of all in rhetoric" stands or falls on the quality of Anaxagoras" teaching. Given the numerous criticisms that Socrates elsewhere makes of Anaxagoras, in addition to the tone of "babbling" and "lofty talk," it seems that Pericles cannot be seriously understood as the most complete rhetorician simply. Indeed, Socrates inaccurately paraphrases Anaxagoras' thought, claiming that Anaxagoras postulated a

\footnotetext{
${ }^{110}$ See PI. Pol. 303e-304e.

11 Ar. Clouds 227-34, Pl. Ap. 18b. On the popular use of "babbling" and "lofty talk" with respect to the study of nature, see Yunis $2011209-10 \mathrm{n}$ ad loc.

${ }^{112}$ See also Alcibiades $I 118 \mathrm{c}$. An ancient tradition attested to the friendship of Pericles and Anaxagoras, and that Pericles defended Anaxagoras from charges of impiety (Plutarch [Plu.] Pericles 32), although the original sources are only from the fourth century, not from the fifth in which both men lived (Yunis 2011 209n ad loc.). The careers of both flourished at about the same time (Nails 23-5, 223-7).
} 
duality between "mind and mindlessness," 113 in order to convey the same criticism he elaborates in the Phaedo. There, he argues that Anaxagoras, who claimed Mind was the cause of being, was unable to provide a principle showing "in what way it was best for a thing to be," and so "did not use his mind."114 In the Gorgias, Socrates says this resulted in "everything being jumbled together, without distinction" such that not the soul "but the body itself was the judge" of what was good. ${ }^{115}$ Pericles is similarly charged with pandering to and inflaming the capricious desires of the many, and so making them wild, unjust, and therefore worse. ${ }^{116}$ Whether or not this fairly represents Periclean politics, Socrates indicates that Anaxagoras, by not sufficiently distinguishing mind and the objects of thought, could not distinguish what is by nature an orderly or better arrangement of those objects, i.e., the "for whom, when, and to what extent." Anaxagoras' "mind" thus justified whatever state of things happened to be the case, and, politically, whatever opinion the many were persuaded of; the natures of mind and mindlessness were indistinguishable. 117 Socrates" supplement of "mindlessness" is therefore a correction of Anaxagoras, creating a pair of opposites that point to the higher

\footnotetext{
${ }^{113}$ Following de Vries, Rowe, and Yunis (2011) in emending Burnet's redundant dianoia with anoia. ${ }^{114}$ Phd. 97c, 98b. Yunis (2011 21 ln 270a 1-2) rightly notes that anoia was not an element of Anaxagoras' thought.

${ }^{115}$ Grg. $465 \mathrm{c}-\mathrm{d}$.

${ }^{116}$ Ibid., 503c-d, 515e-516d, 517b ff. Pace Hackforth, Pericles' "oratorical excellence" is necessarily related to whether or not he was "a bad statesman," for it is the expedient use of the former, in conjunction with his commensurate policies, that produced the wildness for which Socrates convicts him as being the latter (Hackforth 149).

${ }^{117}$ Anaxagoras' desire to conform his concept of Nous to the strictures of Parmenidean monism - that it is "unlimited," "self-ruling," "unmixed," "alone by itself," "purest" - could not be reconciled with his postulation of the mixed "all" that is necessarily separated from Mind as it set itself in motion, i.e., what is not mind and therefore mindless (fr. B12 [DK]). But since Mind is the source of all being, in which there are no opposites, Anaxagoras produced such self-contradictions as "And in all things the other is neither separated nor divided from the other except Mind. But Mind is everything alike, both the greater and lesser" (Ibid.). Without the differentiation of a truly transcendent source of being, mind and mindless prove to be the same. When Socrates concludes that Anaxagoras "did not use his mind," the jibe is stinging because it is merely a deduction from the man's own writing.
} 
principle Anaxagoras was unable to achieve. ${ }^{118}$ Socrates thereby also indirectly censures Pericles.

In his urbane speech, Socrates proposed a similar dichotomy between purely moderate "mind" and "mindless" erōs $(241 \mathrm{a} 3-4, \mathrm{cl})$. The political implications of that speech resembled the democratic conventionalism of Pericles, finding in common opinion the source of all good sense and justice, although its dualistic psychology untenably denied that speech and common opinion had any basis in the private desires of the body. A moderate man had a purely aesthetic interest in intercourse, whether it was with the city, its opinions, or an individual, and so persuasion of the beloved was inexplicable - it was either an act of selfless moderation or of the destructively "mindless" private desire of erōs. On this urbane view, a lover or rhetorician could not have an interest in benefiting his audience, but only his own self-aggrandizement. Consequently, the question of "for whom, when, and to what extent" is of no intrinsic interest to rhetoricians like Lysias or Thrasymachus, but only to the extent that it aids in serving their desires. If, however, they wished to avoid the inevitable failure of their rhetoric by deceiving themselves, mistakenly applying one of their techniques at the wrong time or to the wrong soul, they would have to be able to understand soul in relation to its natural good.

\footnotetext{
${ }^{118}$ A younger Socrates raised an argument resembling Anaxagoras' to contest the necessity of this third term (the "third man") in the Parmenides. Parmenides responded that if the forms (ideai) are "thoughts," then everything that participates in form is a thought, with the result that either everything thinks (and so there is no distinction between thinking and not thinking) or everything that is said to participate in thought is in fact "without thought" (anoeta) and so does not participate in it (Prm. 132b3-c12). Again, if form exists solely in mind or thought, there is no reality, but only an impossible multiplicity of forms and individual thoughts - a multiplicity that could not be grasped without presupposing a singular form, a oneness, that they all share, outside of thought. Anaxagoras' position thus reduces to an untenable relativism.
} 
These consequences of Anaxagoras' understanding of nature are only implicit, and Phaedrus asks Socrates to explain why the study of nature should be part of an education in rhetoric. He responds that it is because "the way [or: manner, tropos] of the medical art and rhetorical art is the same" (270b). He will also explain why the analogy of these arts concluded that the rhetorical art requires knowledge of "for whom, when, and to what extent" rhetorical techniques are to be used. "In both [of these arts]," Socrates adds, "it is necessary to distinguish [diairein] a nature," whether it is the nature of body or soul, otherwise one will only proceed by "knack [tribē] or experience." Without knowledge of the nature of a body, one will not know how to apply various "drugs and diets." This nature is not merely a collection of parts, anatomy, but is essentially what is good for the body as a whole - "strength and health." Without knowledge of the body in its complete and perfect state, one cannot produce the end of medicine, and therefore cannot be said to possess the medical art. Accordingly, one cannot possess the rhetorical art if one does not know how to "apply speeches and lawful practices" in order "to pass on whatever conviction and excellence [or: virtue, aretē] one wishes." The novelty of this function of rhetoric is difficult to overstate, both in the history of Greek rhetoric and within the Phaedrus itself. While rhetoric had of course been used to lead souls to a correct or noble opinion, e.g., Nestor's and Odysseus' exhortatory speeches to the Achaean troops, it had not been associated with the actual production of excellence in the audience. Socrates himself questioned the possibility of teaching virtue throughout his adult life. ${ }^{119}$ In the Phaedrus, this function of rhetoric was implicit in the palinode as "the greatest good fortune" bestowed through erōs, since true lovers were joined in philosophic discourse by a love that sought the knowledge that

${ }^{119}$ E.g., Pl. Men. 71 d-e, $89 \mathrm{c}-$ d, Prt. $318 \mathrm{e}-320$ c; Xen. Mem. 1.2.3-4. Cf. Pl. Clit. $408 \mathrm{~b}$ ff. 
would order, "perfect," and "nourish" their souls (247c-d, 249c-d, 253a, 255a, 256a-b). This is the great use of rhetoric. ${ }^{120}$ But this could only be explicitly stated after a number of obstructive opinions had been refuted, particularly the opinions that rhetoric does not need knowledge and that it consists of the application of techniques in whatever manner the speaker wishes; that is, the popular opinions about rhetoric that teachers of rhetoric propagated, to their gain. Rhetoric, then, claims the power that Socrates attributes to justice in the Gorgias, suggesting a higher or noble rhetoric. ${ }^{121}$ Two forms of rhetoric can therefore be distinguished, the one of artless knack and caprice, the other of art that knowingly cleaves to the excellence of the soul. This explains the apparent equivocation in Socrates" words, that the rhetorical art may produce "whatever conviction and excellence one wishes" - rhetoric is a useful instrument for achieving one's desires, but if the true art of rhetoric is coextensive with knowledge of the nature and therefore excellence of soul, will not the rhetorician's wishes simply consist in the production of that excellence? The question of the Gorgias, whether or not the rhetorician must know and teach virtue, and whether he is virtuous himself, is therefore implicit in the Phaedrus. $^{122}$

With Phaedrus, Socrates approaches the noble rhetoric exclusively through the question of efficacy, where even if the rhetorician's aims are low, they can only be reliably achieved if he possesses knowledge of soul "sufficient for his purposes." Still, Phaedrus's customary response, that "it is likely," shows that he is not persuaded that medicine and rhetoric do indeed share the same "way" (270b10). While an ignorant use of medical techniques will produce ill effects that are relatively obvious, a sham rhetoric

${ }^{120}$ Cf. Grg. $480 \mathrm{a}$.

${ }^{121} \mathrm{Grg}$. 463e ff., 504d-e, 508c, 517a; see also $480 \mathrm{e}-481 \mathrm{~b}$.

${ }^{122}$ Ibid., 456a-457c, 460c-46lb. 
will not be so evident, for, as Socrates himself said, the principal objects of soul "justice," "good," "beauty," "love," etc. - are matters of great dispute, so that the effects of sham and noble rhetoric are easily confused. Thus there is a real possibility of a soul's "conviction" being divorced from excellence, which grants great power and scope to the ignoble use of rhetoric. ${ }^{123}$ For the moment, Socrates conceals this by saying that the rhetorician "applies speeches and lawful practices" - even though what was "lawful" was earlier said to be inhibitory of both human and divine erōs, and it is unclear how a speaker could apply practices without having already persuaded or otherwise compelled the audience (cf. 252a). Socrates thus uses his own rhetoric to ensure that Phaedrus judges the art not according to how it is currently practiced, but according to the perfection seen in speech.

Rather than explicitly taking up the validity of the analogy of health to virtue, Socrates presses on with how the nature of something can be known. He asks Phaedrus, "Do you suppose it is possible to comprehend [lit. to thoroughly understand, katanoēsai] the nature of soul in a way worth speaking of without [comprehending] the nature of the whole?" (270c). Phaedrus quickly supplies the medical analogy: "If indeed one is bound to trust Hippocrates of the Asclepiads, neither [is it possible to comprehend] [the] body without this method [methodos]." In completing the analogy himself, Phaedrus inadvertently draws the reader's attention to a difference between soul and body. Socrates says one must understand the nature of "the whole," but which whole? The

\footnotetext{
${ }^{123}$ In the Republic, Socrates compels Thrasymachus to concede that the strict meaning of art means caring for the good of its object; accordingly, a rhetorician who produces ill in his audience would cease at that moment to practice the true art of rhetoric $(R .345 \mathrm{c}-\mathrm{e}$; also see $G r g .460 \mathrm{~b}-46 \mathrm{lb})$. Aristotle retains the conventional meaning of rhetoric and so admits that the art of rhetoric is open to abuse by those of poor character; but any successful use of rhetoric will first require that the audience either assume or be persuaded of the speaker's good character (Arist. Rh. 1356a).
} 
whole of soul, and, for Hippocrates, the whole of body? Or is it "the whole" simply, that is, the whole of nature? This is an issue of long-standing controversy amongst commentators, and has significant bearing on the nature of the noble rhetoric that Socrates is about to present. On the one hand, Phaedrus surely did not mean the whole of nature, although Socrates' discussions of medicine and poetry implied that the arts were related to a whole greater than their particular objects. It is unlikely that most physicians concern themselves with soul or even non-human bodies, and in addition the following discussion of the Hippocratic-cum-rhetorical method seems to be strictly taxonomic and analytical. ${ }^{124}$ Moreover, the body, as a physical object, can be perceived as a whole unto itself, as seen in the discussions of the "living animal," whose parts are understood in relation to each other and the whole, and how the artful use of drugs and diet produces a healthy whole. On the other hand, a consideration of the dialectical nature of the present passage suggests that "the whole" must be understood as the whole of nature. Socrates himself suggests this procedure when he says that each art "must distinguish [diairein] a nature," that is, use division, diairesis, which is a component of dialectic. Furthermore, the suggestion that the arts of medicine and rhetoric share this "way" (tropos) is itself a collection of the two arts under the scope of dialectic. In simply examining whether the two arts do indeed share this attention to the whole, Socrates must place them in dialectical relation. $^{125}$

\footnotetext{
${ }^{124}$ De Vries 234-5n.270c2, c3-5; Hackforth 150; Hermeias 245, 5; Yunis 211n.270c1-2. The historical question of whether Hippocrates in fact subscribed to this method is an interesting one, discussed in Mansfeld, but is of no consequence to either the analogy of medicine to rhetoric or the argument concerning the method of the noble rhetoric. But Socrates' point seems to be that the Hippocratic method, whether or not they understood it as such, is necessarily of this form if it does in fact show the nature of things.

${ }^{125}$ The interpretation that follows is indebted to Mansfeld 348-53.
} 
Socrates first turns to what "Hippocrates and the true logos say" (270c). In order to become an "expert," a technikos, one must "comprehend [or: to think through, dianoeisthai] the nature of anything whatsoever" by beginning with the basic dialectical problem, which is to determine whether the object is "simple" (haploos) or complex (literally "has more forms") (270c-d). This means that a complex whole may possess a nature unto itself, although this complex can only be understood through its constituent forms. The way to determine whether it is simple or complex is implied in the sequel. Second, if the object is simple, one must study its natural "power" or capacity in active and passive form: "the power it possesses for acting on some particular thing"; and "the power [it possesses] to experience on account of some particular thing" (270d). In more conventional terms, one must study "the deeds and experiences" of the object in relation to whatever it interacts with. As seen in the discussion of antilogic and dialectic, the purpose of this method is to isolate the form on the basis of non-contradiction; if an object undergoes a change in one respect but not another when it is put in relation with another thing, it cannot be truly simple. ${ }^{126}$ From this it would follow that that which produces the effect must also be subjected to division in order to specify whether a particular form in it or the whole of it caused such a change. Third, if the object "has many forms," these forms must be counted - only possible if they share in one form and then, just as with the simple object, each studied with respect to its active and passive powers. A constituent form is thus tested in the same manner as the whole it shares in,

\footnotetext{
${ }^{126}$ In the Republic, Socrates similarly argues that the whole of the soul cannot experience different things, and that it is instead different parts of the soul with respect to each thing. But rather than multiply the parts of soul ad infinitum, Socrates collects the desires as a type under a single part $(R .436 \mathrm{~b}-437 \mathrm{a})$. Parmenides tells Aristoteles and a young Socrates that "a whole cannot both do and experience the same thing at once, and thus what is one would no longer be one but two," and "the one, becoming other than itself, cannot any longer be one" (Prm. 138b). On the "power" of activity and passivity in relation to simple being, see Sph. $248 c-249 b$.
} 
determining its most basic forms. A complex object is itself not tested as to its "powers" for the same reason that that test was able to isolate the simple form - since any contrary effects indicate complexity, the forms responsible for these contrary effects must be differentiated. The test for the active and passive powers of a simple object is therefore also the test for whether an object is simple or complex.

On the face of it, this "way" is analytical and taxonomic, representing only the form of division that "comprehends" the whole as merely a sum of parts rather than a whole with its own powers as a whole. But the test for complexity shows that the forms of the object are only revealed in relation to what is other than it. ${ }^{127}$ The earlier account of dialectic showed that this relation implies a larger whole. For example, erōs was first collected or defined as a form of senselessness, and on the basis of that larger whole was then divided into its human and divine forms, just as the difference between a left and right hand is comprehended only in relation to the whole body. ${ }^{128}$ The analogy of rhetoric to medicine recalls another example, that the difference between soul and body was comprehended in relation to motion. This makes clear that definition ("to bound or delimit") is relational, such that erōs is seen clearly only in the light of a higher form, and this also helps clarify why the most simple forms, the beings themselves that are pure and unmixed, elude comprehensive definition. The larger whole which is implicit or presupposed in this "true account" of how to understand a nature is therefore implicit or presupposed because it is the whole of nature itself - the possibility of comprehending it is the condition of the possibility of comprehending any particular nature, any particular

\footnotetext{
${ }^{127}$ This relation seems to be the same use of the "semblance" by which antilogic moved from one thing to its opposite (261d10-262b8).

${ }^{128}$ Following the explanations in Mansfeld (350) and White (1993 237-8). On the general point that "the whole" must be the whole of nature, Ferrari (1987 76), Jaeger (3.192), Heidegger (1997 §53.232-3) are in agreement.
} 
whole. ${ }^{129}$ The study of the nature of soul or body must share in the same way if both are said to study nature. ${ }^{130}$ Pericles was right to point to the study of nature itself, even if he did not execute it sufficiently.

Socrates concludes that "the method that proceeds without these things seems to be just like that of the blind" (270d-e). This is not to say that the blind man's way is no way at all, but a stumbling without the precise clarity of epistēme - the way of "knack" and "experience." This calls to mind the poets who would compose beautifully harmonious speeches without knowledge of soul, but especially blind Stesichorus. The healing gift of divine Helen was nothing less than the clear vision he attained of her true nature by dividing it from her phantom. Socrates calls this man who sees "the one who crosses over," that is to say, the one who possesses antilogic and dialectic; beholding the differences as they truly are, the natural joints, he is the one most able to move between them in his speech. An artful rhetorician will therefore be capable of "clearly demonstrating the being [ousia] of the nature of this thing" $(270 \mathrm{e}) .{ }^{131}$ Socrates' precise formulation is, though, more general: "should someone teach speeches by some art, he will show clearly the being of the nature of this thing with respect to which he will apply the speeches; and this I believe will be soul." The art of rhetoric is not explicitly named, but rather it is "someone" who "teaches speeches" by "some" art; could Socrates mean that anyone who uses speeches, i.e., anyone who teaches regardless of the particular art?

\footnotetext{
${ }^{129}$ Heidegger $1997 \S 53.232-3$.

${ }^{130}$ Contra White (1993 238), it seems difficult to understand how soul can be completely known unless "each entity in the universe [is also] known," insofar as soul necessarily experiences something in its perception of an entity, and the precise nature and cause of that experience - and so what it affected in the soul - cannot be elucidated without knowledge of that entity.

${ }^{131}$ If ousia is understood as the fundamental nature of a thing, "the being of this nature" would be a particularly clumsy redundancy. The difference between ousia and phusis is obscure. In the present context, ousia seems to refer to the manner by which a nature is, that is, how it is articulated as a whole in all its complexity.
} 
He reminds Phaedrus that such a person "produces persuasion [or: conviction] in this [the soul]," and of course all teaching and learning is done, and all natures seen, through the persuasion of the soul. Griswold shows that the implication of this is that the physician would not truly possess the art of medicine until he understood the nature of soul, for it is by soul that he understands the nature of things. But Griswold rejects this conclusion in the belief that Socrates' intention is to show a merely technical and "value free" method that "determine[s] a priori what the nature of a knowable thing shall be."132 In the most important respect, the complete comprehensiveness implied by this method, Griswold is correct, but he misconstrues Socrates' purpose.

Socrates' formulation of the art of rhetoric follows the comprehensive method ostensibly employed by the Hippocratics. He begins with the distinction between soul and body, saying that the artful rhetorician "must first write and make visible soul, whether it is one and homogenous by nature or multiform like the shape of [the] body" (271a). This is important, because the same distinction is implied in the study of medicine, insofar as its object is the body; the study of body implies the presence of soul, for if all was body, it could not differentiate itself as an object. ${ }^{133}$ This going outside of the body to understand its forms is evident in the Hippocratic writings, which formed diagnoses only by analyzing the body's interaction with the basic elements of nature and

\footnotetext{
${ }^{132}$ Griswold 1986 191-2. Hackforth embraces the universality of the method: he translates $270 \mathrm{e} 2-3$ as "to address people scientifically," explaining "that all important sciences ... must apply to their several provinces the same theoretical treatment - the essence of which is the discovery of the One behind the Many, or the One-in-Many - as physics and cosmology apply to the universe. All science is, or ought to

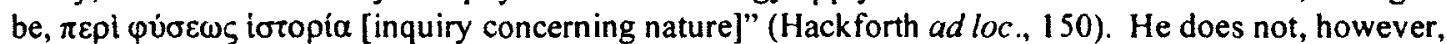
draw the necessary corollary that this universal method depends on comprehending a universal whole, since he interprets Socrates' "the nature of the whole" in terms of physics and cosmology (Ibid.).

${ }^{133}$ Sph. 246 a ff., esp. $249 \mathrm{c}-\mathrm{d}$.
} 
things in the external environment, such as various winds. ${ }^{134}$ Since body is complex, analysis of it in its constituent forms again summons the soul, which alone sees "the being of the nature" of a thing and understands it as a whole of parts. Socrates' formulation of the method of the art of speaking differs from the method of "the true account" in this, that rather than simply divide the whole object into its constituent forms, it also proceeds from this analysis to reconstitute wholes.

In the second step of the method, the rhetorician will show "what by nature it does to what sort of thing or experiences from what" (271a). In the case of the single soul and single speech, this is a simple task, but when a speech fails to persuade or persuades some souls and not others, there must be a differentiation of speech and soul to determine the cause. In doing so, the rhetorician "arranges" or "classifies" (diatattesthai) "both the species of speeches and soul, and the experiences of these" (271b). Socrates' shift from the broader term of "form," used in the first account of the method, to "species" or "kind" has been interpreted to mean that this rhetorical method is not interested in the division of soul into parts, such as in the palinode. ${ }^{135}$ A classification of species, under which particular souls fall, would, however, be impossible without classifying parts of soul, for the differences between species must manifest in the particulars themselves, if all the souls are still to be "soul." Soul is both many and one. An Ares-kin and a Zeus-kin, in the rudimentary scheme of the palinode, would have to differ in a particular form in their souls (e.g., dominance of the charioteer) if "of Ares" and "of Zeus" were not names

\footnotetext{
${ }^{134}$ For example, a change in the direction of the wind, from north to south may produce an excess of phlegm (Hp. Morb. sacr. 13.10-5). Also see Hp. Airs, Waters, Places 1.

${ }^{135}$ Griswold 1986 193-4.
} 
incidental to the functioning of their souls. ${ }^{136}$ The shift to "species" is, rather, nothing more or less than a reminder that the differentiation in soul that is produced by a speech, whether in a particular soul or soul generally, is also a collection of soul in the various kinds that are differentiated from other kinds. In the next formulation of the art, Socrates expressly preserves the coextensive differentiation of kinds and parts, saying that the rhetorician "must know how many forms soul has," from which he classifies them into "such and such sorts" (271d). Forgetting that division implies collection would be tantamount to only seeing one particular after another when applying a speech - which would be no more knowledgeable and probably less effective than experience, which by some knack at least grasps when to apply one speech or another. For example, a soul's "limitless" number of desires could be investigated ad nauseum, but at the expense of forgetting that they were collected for the purpose of understanding deviation from moderation (238a-b). A broader whole is always implicit, and it is only by ascending in generality that the particular becomes manifest in its particularity.

The third step of the method is consequently that the rhetorician, "having classified the species of speeches and souls," "will go through all the causes of these experiences, adapting [prosarmozein] each to each and teaching which sorts [of soul] are [affected] by which sorts of speeches, on account of which cause one soul is persuaded and another unpersuaded" (271b). The causes of the "experiences" of soul are revealed by the complete classification of the differences seen in-between the various kinds of speeches and souls. This correspondence between speech and soul is aptly brought about

\footnotetext{
${ }^{136}$ There was no obvious correlation in the palinode between the division of Olympians and the parts of soul, although the soul of the Ares-kin seemed to exhibit jealousy as a manifestation of the horses' attributes, particularly the anger of the black horse, but perhaps also the love of honor of the white horse. A more precise division of soul than what is found in the palinode would seem to be necessary to grasp the nature of the Ares-kin.
} 
by "adapting," prosarmozein, for harmos is a "fastening" or "joint," showing the true harmonia that was hidden or forgotten by the poets, who thought harmony could simply be a relation of words to themselves. Only the judgment and decision of soul can affirm whether logoi are in fact harmonious. The teacher's role in "adapting" speeches to souls is thus conspicuous, for he too must adapt his present teaching to the soul of his student, rather than point out to the student the real harmonies between speech and soul. The nature of the student's soul must, it seems, be revealed in the same way as other souls, through the observation of his response to the each part of the teaching. As for the teacher himself, he will only be capable of perfectly adapting his teaching to students if he can perceive every differentiation of soul produced by a particular speech, which is to say that the teacher's own soul must be perfectly attuned to the nature of logos. How can this adaptation arise except from understanding the nature of logos and one's own soul by the same method? But if inquiry into the nature of logos presupposes logos, where will the inquirer find the cause of "adaptation" that shows a speech is rightly fitted to soul? ${ }^{137}$ The soul therefore struggles to see what is found through logos in complete distinction from the logos. Such was the struggle of the chariot to emerge from its peers in order to glimpse the nature of being (248a-b, 249c-e).

It has been argued that the taxonomical matrix that is proposed here is consequently defective and not the "true account" it presents itself as, but this greatly overstates what is actually given here. ${ }^{138}$ The three steps simply form a broad outline of the process of teaching, derived from the perception of a change being produced in one object by another object on the basis of non-contradiction. This is complicated by the

\footnotetext{
${ }^{137}$ Benardete 179-81; Sallis 173.

${ }^{138}$ Burger 85-6, Griswold 1986 193-4.
} 
fact that each object is indeterminate in its nature - perhaps it is simple, perhaps it is multiform. A necessary consequence is the differentiation of forms, species, or kinds, and causes, for a being could not come to be other than it is on account of itself. Contrary to Griswold's interpretation, the method here is not a set of rules that proscribes and determines the nature of a being or even the nature of being itself, but the expression of the one rule that what is cannot be what it is not (cf. 245d1-3). Given this one rule, what is left to do is no small thing, but the immense task of discovering and giving an account of the forms that comprehend the vast differentia that may be found around us.

The enormity of the task before the rhetorician underscores the irony in Socrates' words when he concludes that "in no other way will something be demonstrated or said with art, being actually spoken or written, either with respect to this subject or any other" $(271 b-c)$. Socrates thus seems to have arrived at the conclusion of the task he earlier set out, "to persuade Phaedrus ... that unless he should philosophize sufficiently, he will never be sufficient in speaking about anything" (261a). Philosophy seems to be the perfection of dialectic. Dialectic, as the art of the logos by which nature is known, is the art of arts in which all arts must share if they are to be arts and know the natures of their objects. The highest and most necessary of arts is the study of the nature of the human being that "gathers together into one through logismos" (249c). The other arts must look to dialectic to secure themselves in the knowledge of soul and the whole itself, i.e., the truth in the words that "all such great arts need in addition babbling and lofty talk concerning nature" $(269 \mathrm{e}-270 \mathrm{a}){ }^{139}$ This is the implication of Socrates' claim that he is a lover and follower of dialectic "in order to speak and to think," and expresses the full meaning of the art of rhetoric as a leading of soul by words in both public and private

${ }^{139}$ On dialectic as the "synthetic" art of arts, see PI. R. 531c-d, 532b-c, 533c-d. 
(261a-b, 266b). The boast of the art of rhetoric, then, that "without me, the one who knows the beings will not be able to persuade by art," has in a way been confirmed, albeit with the qualification that no one will persuade by art without knowing the beings (261a). Indeed, with this incredible knowledge, it must be that those "who now write manuals [lit. arts, technai] of speeches," are not just clever, but panourgoi, "artisans of everything" modern Daedaluses (cf. 266e3-6). ${ }^{140}$ These men, Socrates tells Phaedrus, must "keep secret the nature of soul," for how else could they possess the art yet not have revealed it in their writings (271c)? On the basis of this contradiction in what is manifest, Socrates attributes to them an esotericism that would somehow reconcile this. ${ }^{141}$ That is, there must be a private rhetoric behind their public deceptions. Or perhaps they do not in fact possess the art at all. Only when they can "speak and write this way [tropos]," and so make manifest and public the stable knowledge upon which their practice rests, "shall we believe they write with art." Just as public rhetoric depends on a private rhetoric, so too does the private depend on the public.

Phaedrus's question, "What way [tropos] is this?" is confusing, as it is obvious that it would have to be the same way by which the rhetorician came to classify and know the nature of soul $(271 \mathrm{c}) . \mathrm{He}$ must not realize that Socrates is suggesting the unity of the public and private rhetoric, a perfectly complete manifestation of the nature of things to all as a proof of artfulness. The artful speaker, possessing the complete knowledge of soul and how logos is adapted to it, will necessarily be able to persuade every soul with respect to what he knows. At this great height, when the object is true knowledge, there is no distinction between teaching and persuasion; any deception would occur only on

${ }^{140} \mathrm{Hp}$. Ma. 285b-e, Hp. Mi. 368b-c; cf. Euthd. 293e ff., Grg. 453d-454a, 454e.

${ }^{141}$ Socrates uses the same device to instigate an inquiry into Protagoras' teachings (Tht. 152c-e). Compare Protagoras' own discussion of esotericism in teaching politics and virtue (Prt. 316c-317c). 
account of the ignorance of the student. ${ }^{142}$ Socrates, artless and ignorant of the great things the dialectician and rhetorician must know, demurs that "the words [rhēmata] themselves will not be easy to speak," as he would have to go through the entire classification of speech and soul according to their forms and species. In using rhèmata rather than logoi, Socrates calls to mind the rheuma, the flowing, of the parts (merē) of beauty into the soul of the lover. The transmission of the things themselves therefore eludes Socrates (255c1, c6; see also 251c7). But he can say "how it is necessary to write if it is to be as artful as possible," i.e., the basic conditions for the manifestation of knowledge (271c). Phaedrus's question therefore allows Socrates the opportunity to recapitulate the whole account of the dialectical method that the rhetorician must follow if he is to become artful.

The noble rhetoric is found in the rhetorician's education in the nature of soul. Only when this education is complete will he be capable of speaking and writing nobly or beautifully - the end to which the entire discussion of rhetoric aimed (258d4-5).

Education begins in the same manner outlined in the study of nature: the rhetorician must first "know how many forms soul has," enumerate and classify them into "such and such sorts" and whence "they come to be" of one sort or another, and "having distinguished these, again there are so many forms of speeches, each such and such a kind" (271d). From this he will know "which sorts of people are easily persuaded to this sort of speech on account of this cause, and which are hard to persuade on account of these [causes].",143 Once these preliminaries are concluded, he will "see these in practice both as they are and

${ }^{142} \mathrm{Cf}$. Ti. 51 e. Gorgias' ready acceptance of the distinction between learning and persuasion leads to his refutation on the grounds that rhetoric, if it is only concerned with persuasion rather than learning, has nothing to teach ( $G r g .454 \mathrm{e}, 456 \mathrm{a}, 458 \mathrm{e}$ ff.).

${ }^{143}$ See the similar passage in $\mathrm{Grg}$. $513 \mathrm{~b}-\mathrm{c}$. 
being put into practice, and be able to attend to them sharply by perception, or they will be nothing more to him than the speeches he earlier heard when I was with him" (271de). The rhetorician must "be able to show to himself that this man he perceives is of the same nature which the previous speeches were concerned with, now present in deed" (271e-272a). A strictly discursive education is therefore insufficient, despite the seeming self-consistency that accompanies it; the rhetorician's knowledge must include what lies outside of speech in the complicating mixture of soul and body. He must be able to descend down to and account for the particulars themselves, resolving as he is able the difference between speech and deed.

Curiously, this turn to practice had not been mentioned in the earlier discussion of method, and is presented after the student had gone through his classifications, as if the classifications were ready-to-hand and could be accomplished without reference to the use of speech in practice. What Socrates has himself hidden from sight, then, is the artless stumbling of the autodidact, who does not fit particular souls to pre-given categories, but must discern those forms as he converses, "following the scent" as it were, by observing the effects of his words on them and looking for patterns amongst these souls. This of course must have been the way that the first teacher first established his classifications, but Socrates presents to Phaedrus this education as if the art of rhetoric is already complete in its formulation and founded on proven principles.

On the basis of this supposedly complete art, the student will see his education bear fruit in his persuasion of "the man now present in deed." With his knowledge of speech and soul, he knows "to whom he must apply these speeches towards the persuasion of these things" (272a). Such is the necessity conferred by complete 
knowledge of the nature of things; no capriciousness on the part of the artful rhetorician is possible, but only conformity to the necessary relation between the nature of soul and nature of speech. With this, the crowning achievement of the rhetorician is in hand:

By having already grasped all these things, then taking hold of the right moments [kairoi] when he must speak and refrain, and again for both speaking concisely and piteously and indignantly and for each form of speech he may learn, distinguishing both the right moment [eukairian] and wrong moment [akairian] for these, will the art have been brought to perfection beautifully and completely [teleoss], but not before. (272a)

The kairos, the "opportune moment" or "season," is Prodicus' "measure" (metrion) between two extremes. 144 It was seen in the medical analogy as the "for whom, when, and to what extent." For poetry, it was the fitting of high and low into a harmonious whole. In rhetoric, the fittingness of the drugs employed, the techniques of a Gorgias or Thrasymachus, does not lie in the techniques themselves, but whether they are eukairia or akairia in relation to the soul of the audience. Nor is a technique considered fitting simply because it has produced the effect desired by the speaker, unless that desire is for what is truly fitting for his audience. In grasping what is kairos for soul, the rhetorician's knowledge of soul is completed, for the nature of soul is understood only in what is best and most fitting for it. It seems that just as the physician cannot be said to possess the medical art without knowing what constitutes a healthy body, neither can the rhetorician possess the art of speaking without knowing what constitutes excellence of soul.

Moreover, this knowledge is both universal and particular, for only in knowing what is good for soul simply will the rhetorician discern what is good for the particular soul that is "present before him" "in deed." As knowledge of soul entails knowing "the whole," i.e., the nature of the things themselves by which soul is perfected, the discussion of the

${ }^{144}$ Pol. 284e, 310d-e; Lg. $916 \mathrm{e}$. 
art of rhetoric has come full circle with the palinode, perfecting (telein) the human soul as it perfects that by which it grasps the nature of things (250b5-c6). Speech-craft is therefore a matter of soul-craft, producing not simply the whole speeches called for by "logographic necessity," but whole souls. Accordingly, the question still remains whether the artful rhetorician, in knowing what is fitting for soul, has perfected his own soul. Can he "fit" speeches to another without having so fitted his own?

Again, the expansiveness of the knowledge that is required of the rhetorician is difficult to overstate, as knowledge of soul and logos will touch on, if not determine, every art and how the logoi concerning their objects affect and persuade the soul. This is not simply knowledge of which speeches are effective with which souls, for a true grasp of logos entails knowing what is truly persuasive, which can only be knowledge of the beings themselves. ${ }^{145}$ This, to be knowledge, must transcend the finitude of speech and relate to the eternal causes, which the rhetorician-dialectician somehow takes hold of. From this view, Socrates' attribution to mantic prophecy the first place amongst the arts, "the most beautiful art by which the future is distinguished," can be reconciled with the sober classifications of the dialectician. The complete dialectician, perfectly knowledgeable of the unfolding of being, yet moderate by virtue of his concordance with the nature of things, would be the perfect prophet; only the merely mortal prophet would experience madness with his art. The dialectician would be like the gods of the palinode, effortlessly ascending to and descending from the beings themselves, and most akin to Zeus, leader of the gods who arranges the others according to their nature; this is why Socrates would follow the dialectician "as if he were a god" $(246 \mathrm{e}, 266 \mathrm{~b})$. But the crucial being by which what is fitting for soul and all else, the good itself, was hidden in the

${ }^{145}$ See Grg. 503d-504a. 
palinode, which was a "human telling" of what soul resembles, rather than the "divine telling" of what it is (246a). This beautiful vision of the complete dialectician does indeed set for rhetoric a high and perhaps impossible standard. ${ }^{146}$

Socrates' application of this standard to those who now practice rhetoric is, then, as much a rhetorical strategy as inquiry into the true nature of techne, for whomever is "lacking in any of these things," i.e., knowledge of species, discernment of particulars, and grasp of the kairos, "when speaking or teaching or writing, and says that he speaks with art, the one who is not persuaded is stronger" (272b). Questioning of the rhetoricians with respect to their knowledge of soul and its good is taken up in the Gorgias, but here Socrates does not have Lysias to question, and must rely on his writing. Perhaps Lysias does have a keen perception of what is persuasive to the many, but whether or not such speeches are fitting is another question, and Lysias' indifference to that question refutes any claim he has to knowledge and indicts him for harming the soul. Socrates, on the other hand, by taking a position of doubt and ignorance, will not mistake his own speeches for art. He knows the conditions for art and can seek it in the proper manner; he does not have the kairos, but only the erotic art and its accompanying knowledge, that one is in need of and must search for what is truly fitting and good.

In honor of this stronger position, Socrates does not conclude the discussion, but solicits argument and further conversation: "perhaps the writer will say, O Phaedrus and Socrates, does it seem best [dokein] in this way, or must the art of speeches somehow be said in another way?" (272b). Plato has written in a playful ambiguity with "the writer," for it cannot mean Lysias, whose "method" has already been refuted, nor a would-be rhetorician in the new "manner" of rhetoric that has just been presented. This "writer"

\footnotetext{
${ }^{146}$ Burger 6.
} 
would therefore be cognizant that missteps or deceptions had occurred in Socrates' discussion of the art of speaking and found his division and collection in some way deficient; the principle may not yet be fully articulated. The writer in question may of course be Plato, for it is the author of this dialogue who determines whether a line of argument has satisfactorily reached its conclusion, or if something still remains that the whole writing depends upon.

For Phaedrus's part, it is not faults in argument that repels him, but rather the amount of toil involved in the way of dialectic. "It is no small deed," he tells Socrates (272b). The older man agrees that the way to the rhetorical art is long and hard, and "we must turn all the speeches up and down" to see if there is an "easier and shorter [brachutera] path," "in order not to waste time going on a long and rugged road, should there possibly be one short and smooth." Phaedrus must go back over the arguments and review them. Has Socrates collected and divided rhetoric properly? Is the medical analogy fitting? Are the techniques of definition and logographic necessity really necessary and if so in what way? Is all thinking by collection and division? Socrates' advice is that Phaedrus take their opposites, i.e., if they are not true, and then see what is left of the art of rhetoric. ${ }^{147}$ Perhaps the way does lie with Teisias and Gorgias, who boasted of "concise" (brachus) speech, although Prodicus seemed right to say that a "fitting" speech is necessarily preferable to either, for what is short and easy should not be desired if it is not good. Prodicus found this rustic wisdom in Hesiod, who wrote: "Badness can be had easily, but between mortals and excellence (aretē), the gods have placed sweat upon our brows; long and steep is the path to it, and rough at first."148

${ }^{147}$ Cf. Prm. 136a.

${ }^{148}$ Hes. Op. $286-93$. 
Prodicus modeled his famous speech, Heracles' Choice, which Socrates himself was known to quote, on the same choice of paths between Virtue and Vice. ${ }^{149}$ His admonishment of the desires of Vice would be a fitting lesson for Phaedrus, whose desire for painless pleasure in the form of speeches has made him indolent, as their present beauty offers a false escape from the toil that is necessary for mortal life (248c). What seems to be long is only so in relation to habit and inclination, which, as the palinode and myth of the cicadas illustrated, is the desire to face no resistance and to have what is pleasing before us at all times. But, if there is no such easy and smooth way, the heaviness of compulsion must be embraced with willingness, bringing desire and toil into harmony for the sake of what is better.

\section{Probability}

"It is said, Phaedrus, to be just to also give the wolf's side" (272c). In opening this contest as a matter of justice, Socrates sets himself against the non-lover, who only castigated the lover as "a wolf" without allowing for the possibility of his exoneration; the non-lover's duality of erōs versus moderation refused real deliberation, and with it the possibility of justice beyond the rule of common opinion. When Teisias, imitated by Socrates, takes a similarly conventional approach to the matter of justice, he therefore does so in the shadow of the more expansive justice by which Socrates has allowed him his rebuttal. For Socrates, justice is only served by dialogue that aims to take hold of the truth. He will, in dialectical fashion, put his own account of rhetoric as a kind of dialectic to the question by taking up the case of Teisias' probabilistic forensics as its opposite or negation. What is at stake, however, is not just a form of speaking, but the very

\footnotetext{
${ }^{149}$ The principal source for Prodicus' speech is Socrates' quotation of it in Xen. Mem. 2.1.18-34.
} 
excellence of soul, which the noble rhetoric - and artfulness itself - was said to depend upon.

Teisias' objection is that persuasion occurs and can be readily, and artfully, produced by the rhetorician without true knowledge. He says that there is "no need to exalt [the matter] or lead up [to general principles], going around the long way, for it is as we said at the beginning of the speech: the man who is practicing to be a sufficient rhetorician would not need to share in truth concerning just or good actions [pragmata], or even whether humans are such a sort by nature or nurture" (272d). Teisias will thus make the final case for Phaedrus's opinion about rhetoric and persuasion, which is a surprising admission on Socrates' part that the argument had not yet been settled. Indeed, Socrates' Teisias draws attention to at least two points about dialectic that had not been explicitly discussed. In the first instance, Socrates never claimed that dialectic and the teaching of rhetoric "leads up" to general principles, but only that rhetoric depends on knowledge concerning both the subject matter and the soul of the audience, which entails the collection of particulars into kinds or types. That justice itself or the good itself are archai or first principles would, of course, be a crucial premise for establishing knowledge of "just actions" or "good actions," but it was unclear whether collection and division could actually establish the principles upon which they depend or presuppose. ${ }^{150}$ Socrates' Teisias has interpreted the art of speaking as claiming that it can lead directly to true knowledge.

A second point that had not been discussed was "whether humans are such a sort by nature or nurture." Socrates had simply spoken of souls that had "natures" irrespective of their potentiality for change (270a1, b4-5, c1-2, c9-d7, e3-4, 271a6-8, a10, ${ }^{150}$ Arist. EN 6.6, Posterior Analytics 2.19, Top. 1.1-2, 8.2. 
272a1). Only once did Socrates speak of the soul being affected by custom (270a7-8). Teisias here draws attention to the fact that a soul is changed by persuasion - a necessary proposition if either persuasion or learning is possible - and that a soul of one type may become (or reveal itself to be) another by consequence of the speeches applied to it. As a case in point, a soul persuaded by Socrates' arguments in the Phaedrus would become more obstinate to Teisias' form of persuasion. But this also suggests a problem for the noble rhetoric as Socrates has proposed it: given that application of speeches is necessary for understanding soul, a wholly natural account of soul is extremely difficult to obtain the ever-moving soul conceals itself. It is in light of these problems that Teisias makes the case for addressing ta pragmata as separated from knowledge of the truth, and should therefore be taken seriously as an argument against the theoretical investigation of the nature of things.

The argument that Teisias advances is that the rhetorician need only take up what is "sufficient" for his purposes. As Socrates pointed out at the outset of the discussion of rhetoric, action and use are crucial for determining whether a donkey is a horse or a speech good or not. He then went on to stipulate that one must know what is useful or good for soul if one is to speak artfully. Teisias, in contrast, proposes that use or "sufficiency" is simply determined by expedience or the whim of the rhetorician. In lawcourts, no one cares for the truth, but only "for what is persuasive, and this is the likely (to eikos), which is what the man who is practicing to speak with art must attend to" (272d-e). Even if that truth is on the side of a litigant, "sometimes it is even necessary to say not what has been done, if it is unlikely, but the likely things, both when accusing and defending, and to pursue saying the likely in every way, often saying good-bye to the 
truth." Plato has had Socrates put in the mouth of Teisias an incredible indictment of forensic practice and institutions, echoing similar sentiments expressed elsewhere, such as in the Apology and Theaetetus. The digression in the Theaetetus in particular, concerning the difference between the clever lawyer and the philosopher, helps to explain how Teisian rhetoric may claim such power despite its admitted ignorance.

The digression is introduced with a brief discussion of relativism concerning "the political things." A rhetorician will admit that whatever a city lays down as custom or law is not always to its advantage, but at the same time deny that there is any natural justice or injustice beyond force or law. This was Thrasymachus' argument in the Republic. ${ }^{151}$ With this background, Socrates first presents the philosopher who, having spent his life looking to the nature of things, bumbles about when he finds himself involved in the business of the city and the courts. The litigators, on the other hand, who are concerned only with following the strictures of the court and attaining a desirable verdict, are likened to slaves before the master who judges. These men, because they lack any concern for what justice actually is and embrace the lie, "become small and crooked in their souls," yet believe themselves clever and wise. ${ }^{152}$ But when compelled to look beyond disputes about who has wronged whom, and to see what justice and injustice actually are, these men become "dizzy" and are "perplexed and stutter," although the many who are ignorant "do not perceive" his condition. ${ }^{153}$ In the Phaedrus, Teisias' argument is remarkably similar to that of the clever litigants. Like them, his primary concern is to produce the desired verdict, by whatever means, within the strictures imposed by the understanding of justice found in the law. Unlike the

\footnotetext{
${ }^{151}$ R. 338e-340a.

${ }^{152}$ Tht. $171 \mathrm{e}-173 \mathrm{~b}$.

${ }^{153}$ Ibid., 175c-d.
} 
politicians, they do not concern themselves with legislation. Although legislation may be mere flattery, as Socrates insinuated earlier, it may also entail inquiry into the natures of law, justice, regime, and consequently the nature of the human being. ${ }^{154}$ Socrates' noble rhetorician, who produces persuasion "in conformity with nomos" because it is good for the soul, appears to be the antipode of Teisias, who advances a conformity with nomos so far as it exists only in the jury's opinion, regardless of whether it is truly just. There is no philosophical antipode to the clever lawyer, as there is in the Theaetetus. The absurdities and impracticalities of the apolitical philosopher are here hidden.

The distinction that Teisias draws between truth and persuasiveness depends on the hiddenness of truth and its at times fantastic appearance. Images of the truth may be more attractive and persuasive than the truth itself, which is to say that people are drawn to what should be the case as they themselves conceive it - their own opinions. Socrates made similar arguments in the context of psychagogia, as the rhetorician was compelled to begin with his interlocutor's opinions and draw semblances between them and the opinion he wished to produce. One does not gain knowledge simply from the perception of the truth, as one could infer from the palinode. Therefore, the critical issue at hand, what makes Teisias' argument credible, is the nature of the souls of both the litigants and their audience and how "the likely" may come to be preferred over the truth. As noted with respect to Lysias' speech, this audience is the jury which, in the case of Athens, is the dēmos.

Why is it the case that the likely may be more persuasive than the truth? Teisias says that "the likely [to eikos] is nothing other than what seems to be so [dokein] to the

${ }^{154}$ This seems to account for the subordination of the "lawful king" to the philosopher, for the former must look beyond what is enshrined in law to determine its justice and goodness (248d). 
majority" (273a-b). Phaedrus recalls that something similar was said earlier; in fact, it was he who said that "it is not necessary for the one who intends to become a rhetorician to understand the just things in reality but what seems so [ta doxanta] to the majority who judge, nor the truly good nor beautiful things but what will seem so [dokein], for persuasion comes from these things and not from the truth" (259e-260a). Perhaps Phaedrus heard this opinion from Teisias' writings, or second-hand from Teisias' student Lysias. Regardless, Socrates is now concerned explicitly with public rhetoric and how a "knack" for persuasion may in fact be possible. His earlier refutation of Phaedrus's opinion was not complete, for it did not address how a city can be deceived about justice and good because they are disputable things. Socrates' sarcastic comment that Teisias "discovered this wise and artful thing" can consequently be understood more seriously, for the efficacy of probability will be instructive about the nature of "the majority" or "the many" (273b3-4). Socrates himself will say that the efficacy of any speech necessarily depends on hitting upon something of the truth.

The relation between probability and the nature of the many can be seen more clearly in the example that Teisias provides of his probabilistic forensics. A weak but brave man assaults a strong coward and steals his cloak. When they come to court, Teisias counsels that neither should tell the truth; the coward should say he was assaulted by more than one man, and the thief should insist that they were alone, and use the argument, "how could I, being such as I am, have assaulted such a one as him?" (273c). Since the coward is unwilling to admit his cowardice, he will make other lies and give the thief the opportunity "to refute him." The simplicity of this example is deceptive, as there is a complex relationship between the two qualities, strength and bravery, and the 
jury's ignorance. This interrelation of strength and bravery produces two of the probabilities that inform the litigants' strategies: a strong man is more likely to prevail over a weak one; and a brave man is more likely to prevail over a coward. There is a third probability that seems to be a corollary of these: a brave man is unlikely to be unjust. Each of these probabilities arise because of the ignorance of the jurors, not only due to their absence from the event, but also due to their unfamiliarity with the men, the mixture of the two properties, strength and courage, and in the present case the assumed relation of those properties to a physical contest.

The first point of ignorance is simple, but crucial for probabilistic reasoning: because the jury was absent from the event, the truth of it is unknown. Instead, the jurors are asked by Teisias to conjecture based on past experience. The second point is that the two men are unknown with respect to their relative bravery, but are known with respect to their relative strength, which forms the basic premise for their arguments. Some form of truth and knowledge is required as the basis for deceit, or at least a proposition that is agreed upon, for people only believe what they think is true. The next point, the third, is the most revealing of the soul of the many. The jury conflates bravery and strength, which, though distinct, resemble one another. For example, in Socrates' urbane speech, a man with a weak body "emboldens enemies and causes fear in friends" because it is assumed that a strong body is necessary for success in battle (239d; cf. 270b7). Having the two litigants before them, without further knowledge of the two men, the jury can only see their relative strength. They assume, from experience, that the physical property of strength is a determining factor in a physical contest, with the result that the stronger man could not have been assaulted by the weaker. The many judge the case according to 
what is visible in deed rather than by words to the contrary. Sight, Socrates said, is the clearest and sharpest of senses, although it is that same clarity and grasp of the whole of the thing that deceives with respect to the truth, which is only visible to the mind. Bravery is not discernible simply in the bodies of men, but is a quality of soul that makes it one of the "disputable" words (like "justice" or "good"), which Teisias takes full advantage of. He advises the coward to hide his cowardice because of this conflation of bravery and strength - it is unlikely for a strong man to be a coward - and because of the similar proposition that is unlikely that a brave man would be unjust - one virtue resembles another. The coward does not admit his cowardice because he is ashamed, but because no one would believe him, and they would expect a coward to be ashamed and fearful of popular opinion. From these common opinions concerning what is, certain expectations about the course of events can be readily generated. The opinions that the jury holds concerning these general propositions are therefore not disputed. Teisias' discovery of such a "cleverly hidden art" is of course no great discovery, for it is nothing more than a collecting of popular opinions that would not meet resistance in a jury deliberation that amounts to little more than a vote. ${ }^{155}$ As Socrates noted earlier, this beginning from common opinion is only one facet of psychagögia.

Socrates' response to Teisias' probabilistic forensics, and thus final refutation of Phaedrus's opinion, is a recapitulation of the method of education in the noble rhetoric. This reconciles Teisias' argument with what had already been established: "We have for some time been saying this probability [to eikos] happens to be generated amongst the many through a semblance of the truth, and just now we came [to the conclusion] that in every case the one who knows the truth knows best [lit. most nobly, kallista] how to

${ }^{155}$ MacDowell 1978 119, 251-3. 
discover these semblances" (273d). Socrates' response is in fact a third formulation of the art of rhetoric that gathers together Phaedrus's original opinion about rhetoric, antilogic, and dialectic, with Teisias' probability.

Teisian rhetoric is accordingly subjected to the same arguments as before: probability is a natural effect on the many that is "generated," rather than simply made or produced. Teisias and Gorgias take advantage of what naturally arises in the soul, and so cannot simply produce whatever conviction they please, but one that must be in conformity with the opinions and desires of the many. Just like the true rhetorician, Teisias must be able to discern what sorts of speeches produce the desired effect with the many. The semblances that he draws on have a natural basis - they touch on reality. If one wishes to go beyond opinion polling and actually know how to use those opinions, Socrates argues that the rhetorician, even the probabilistic litigator, must understand the causes of these opinions. In the given example, Teisias' advice depends on his knowledge that the many believe strength to be greater than weakness, courage greater than cowardice, and courage incompatible with injustice.

Socrates' description of the argument, "how could someone such as I am have assaulted one such as he is?", as a "semblance" gives a clearer picture of the knowledge implied by Teisias' technique, and the cause of its power. This probability is a semblance of truth because it acknowledges, first, the truth that strength is greater than weakness and, second, the ignorance surrounding the particular case, in which the jurors have before them a strong man and a weak man, but are ignorant of any other intervening properties, e.g., bravery. The power of the probabilistic proposition is, then, that it encompasses, like all semblances, the problematic relationship between that which is 
simply true and its manifestation in particular cases. Is strength the ability to lift weight? Is it success in physical contests? Is it resoluteness in the face of defeat? Is it prevailing over another? By setting aside the truth, the probable is able to encompass the range of opinions attached to "strength," which might contradict one another, and yet nevertheless infer from them a consensus about the most evident of cases. In this way, the desire of each individual for the truth, ${ }^{156}$ expressed in their opinion, is reconciled to their ignorance concerning both the true nature of "strength" and the particularities of the case at hand; the many possible opinions can thus be addressed by the one probability. As was the case with Lysias' speech, the crowd's contrary opinions are ameliorated and the crowd is reconciled with itself. From solipsism arises a great conformity.

"What the many believe" is, therefore, very similar to what any given reader of the Phaedrus may believe, for it is the natural tendency to a holism that may in the end be too ready and hence unsatisfactory. This springs not from any particular malignancy, but from the same font of "the human form," namely a natural and necessary desire to be reconciled with that which truly and completely is, to reach a complete and uninterrupted self-satisfaction (249bl). The ready identification of the form of the being with a particular instance of that form produces a love of that particular and one's own opinion, and this effect of self-love comes to be multiplied en masse in the many. The contention that arises from this mass of particulars can be abated by the gratifying semblance of the whole found in probability. The universal pretension of Teisias' probability thus raises the possibility of a universal logos, one that will persuade "the many" in the broadest sense. This allows Socrates the opportunity to finally formulate the complete training of the rhetorician in terms of the universal knowledge portrayed in the palinode. Only when

${ }^{156}$ See Phdr. 248b, and cf. R. 505d. 
the rhetorician can count the natures of those who will be listening to him and he "is able to divide the beings [ta onta] according to their forms and to embrace each, one by one, in one form," will he be a "technikos of speeches" (273e). The full scope of the rhetorician's education is revealed to be the return to the beings through their intellectual division and collection. This enormous task is at least qualified: one must do all these things "so far as possible for a human being" (273e-4). Only a divine technikos of speech, who grasps "the one form" will be able to precisely divide it in speech into all its particular manifestations. A human form of the noble rhetoric is therefore distinguished from the perfect case that must be the standard for art - it is a human way that, though incomplete, is devoted to and follows the divine. The old rhetoric that forgoes knowledge is thus cast aside as the merely human, represented by Lysias and his moderation, that does not even recognize its natural subjection to a greater ordering power.

Socrates formulates his refutation of Teisian rhetoric as a restoration of the separation between the human and divine: "For indeed, Teisias, it is necessary, say those wiser than us, for those who have intelligence [or: mind, nous] to practice not at gratifying fellow-slaves, except as a subordinate task, but [at gratifying] masters who are both good and from good stock" (273e-274a). This conclusion does not proscribe the use of Teisias' probability, but only the way of rhetoric that does not see beyond the opinion engendered by probability - that there is no truth, but only what is likely, and that that is sufficient for the purposes of a human being. Phaedrus's opinion concerning rhetoric is thus given the same judgment meted as the litigators in the Theaetetus - they debase themselves by seeking "the gratification of fellow slaves" rather than "what is gratifying 
to the gods" (274a). ${ }^{157}$ The long labor that is education in dialectic is thus justified by true knowledge concerning what is fitting and good for soul, which, being truly good, as Socrates told Phaedrus earlier, would rightly be called "something divine" (242e). What is at risk with Teisias' rhetoric, concerned as it is with extracting a judgment regardless of its true justice, is not reputation, wealth, or one's own body, but the soul itself, for in saying good-bye to the truth, one ceases to orient oneself by that alone which provides for one's own good and flourishing.

As seems appropriate for the Phaedrus, being a transcendent dialogue, Socrates is unequivocal that there is no freedom in the city and in pursuit of the ends most frequently found there, as Lysias" "free" non-lovers would have it. Neither, however, is there an escape from this bondage - one gratifies fellow slaves or gods and remains a slave regardless - but only that blessing which accrues from assent to one's betters and strict adherence to that which is good and whole and complete. The lot of the human is bondage to a whole greater than himself, to which he may open or close himself. Such would be the fruits of a complete education in the art of speech or dialectic, Socrates tells Phaedrus, and "if the period [periodos] is long, do not wonder, for it is for the sake of great things that one must travel around, not [for the sake of such things] as you believe" (274a). For Phaedrus, who longs to leave this world in an indolent pursuit of painless pleasures, a reconciliation with the limitations and bonds of mortality is most fitting. It is no mean achievement of Socrates' rhetoric, then, that Phaedrus responds that this vision of slavery is "altogether beautiful, if indeed someone were capable of it" (Ibid). Unlike the beautiful palinode, the present prosaic discussion of art and technique, harnessed to

\footnotetext{
${ }^{157}$ It should be noted that the practical consequences of the way of the litigators (and the opinion of Phaedrus and Teisias concerning rhetoric) stem from Protagoras' dictum that "man is the measure of all things" (see Tht. 171e-172c, 177e-178b).
} 
what is useful rather than aesthetics, has brought beauty into the realm of possibility. What is truly beautiful and good exceeds what is merely human, for it is the excellence and perfection of the human, not its mean. Phaedrus's hesitation is not to be despised, however, for it is the awakening of the philosophical wonder that darkly glimpses an unwavering perfection; only in light of this is the smooth and easy road is perceived as it really is. The awareness of the insufficiency of this road, the doubt of its goodness, and recognition of one's own ignorance, is what keeps open the possibility of the higher way. When Socrates gently consoles Phaedrus, that "for he who attempts what is beautiful, it is beautiful to endure what should befall him," he quite fittingly and beautifully leaves the problem of possibility unresolved, for only if the truth is unattained in deed will thought go out in search of it (274b). ${ }^{158}$

With the resolution of Teisias' objection, Socrates and Phaedrus conclude their discussion of "art and artlessness of speeches" (274b). The problem that was dramatically subordinate to the examination of Lysias' art of writing and way of life emerged as the most pressing and primary problem: how speech itself is capable of leading the soul through human ignorance towards divine truth. The refutation of Teisias left unresolved, however, the most crucial question for those who would gratify the gods rather than their fellow slaves. Socrates asks, "do you know in which way you may most gratify a god with respect to speeches, either performing [or: doing, prattein] them or talking about them?" (Ibid.). This is a peculiar question, since the whole of the preceding discussion aimed to show the nature of the complete art of speaking and how one might acquire it through the study of soul and its manifold relations with speech. At the very moment when the noble rhetoric, founded on the perfection of dialectic, was to ${ }^{158}$ R. 506b-d. 
be crowned as the highest and noblest way to bring oneself into accordance with what is divine, the spell is disrupted and the beautiful monument of rhetoric subordinated.

The highest way is not directly known to Socrates, but he suggests to Phaedrus that he has heard something of it "from the forbearers, and they alone know the truth" (274c). If the wisdom of the ancients could be discovered without aid, "if we were to discover this ourselves, would we care anything for the opinions [doxasmata] of mere humans?" The return to ancient wisdom coincides with the care for common opinions, for what "seems best" (one of the connotations of doxa) to other human beings. Humans alone cannot discover the truth as if they were gods, but must seek it through opinion and conversation with their fellows, that is, through semblances of what is truly good. Nussbaum rightly points out that our "food of opinion [...], though less fine than the gods' food, is both the best we can get for our horses and a necessary item in our search

for understanding and the good life." 159 It is because these opinions share in what is good that someone can develop a knack for persuasion and leading souls without theoretical comprehension, and that learning is itself possible ("recollection"). It is why Socrates can and must turn from the final and highest things to those that are first for human beings.

\section{$X$. Socratic Rhetoric}

Socrates has, throughout the Phaedrus, but especially in his discussion of rhetoric, portrayed himself as a rustic man who is ignorant, artless, and inspired. His grasp of the comprehensive noble rhetoric founded on dialectic came to him through "some chance" and the inspiration of "the gods of this place," rather than his own possession of the art of

${ }^{159}$ Nussbaum 214. 
speaking and the knowledge that accompanies it. How is his own rhetorical practice to be understood, then, if he does not possesses complete knowledge of the soul, let alone the whole? How has he come to grasp the principles and "method" upon which the noble rhetoric is established? Moreover, how can his presentation of soul in the palinode - its definition and account of its "deeds and experiences" - be reconciled to this professed ignorance?

Socrates explained that he was able to perceive the principles of art because he was inspired and maddened either by the cicadas of the Muses or the nymphs of Pan. That is to say, he was filled with a divine madness that disclosed the nature of things this madness was shown in the palinode to be erōs. Socrates' artless perception seems to be a consequence of the pre-incarnate knowledge that inspires and guides erōs; his glimpse of the eternal nature of things is not by his own work, but granted to him as a recollection. The particular definitions that he cited as examples of art, moreover, are nothing more than reminders. This artless grasp of the conditions for knowledge seems to be the solution to the problem that dialectic, as the manner by which knowledge is acquired, can be secured and known by nothing other than dialectic. There must be a form of knowledge prior to dialectic, whether in its formal sense or common sense of conversation. This is one of the reasons why the palinode and its account of erōs took the form of a myth, for a logos could not disclose the cause of its own being. The incomplete definition of soul in the palinode was in accordance with erōs: a longing for and therefore lack of unity. Since Socrates knows that he lacks the knowledge which befits the name (e.g., true knowledge of the beings [247c-e]), his definition captures well the nature of soul as shown by his experience. That artful definition of soul can be said to be a product 
of art because it is based upon the fundamental premise that he knows that he is ignorant. That Socrates claims for himself an art is therefore not incredible, for he does indeed know something, and it is fittingly called "the erotic things," i.e., expressions of the knowledge of ignorance. As argued in Chapter III, this art consists of such knowledge and how to produce it in others - just like any other art - which, in practice, entails the refutation of what is assumed to be knowledge, i.e., an opinion. The highest erotic life, philosophy, proceeded as a search for god because of the basic premise of human ignorance. Such a way of life does not seek to instill this or that speech as if it were knowledge, but to use speech as a way to secure knowledge of the true beings that transcend discourse. ${ }^{160}$

The absence of this knowledge, knowledge of that for the sake of which one speaks, is accordingly the cause of the sequence of arguments made in the dialogue on rhetoric. Even as the basic argument of each part was resolved, the premise that secured that resolution became the object for examination in the sequel. In each case, it was the awareness that the present account of the nature of rhetoric had not been sufficiently demonstrated that propelled the dialogue onward, where each resolution was contradicted and brought into question. This was the action of erōs. This was not simply Socrates' erōs, but Phaedrus's as well, as can be seen in every question or expression of confusion. For example, Phaedrus wondered that dialectic was the nature of rhetoric, which seemed contrary to all practice. In that case, the tension between collection and division was only resolved through this very erōs that bound each to the other in the face of their respective deficiencies; dialectic as a whole could only proceed in the face of a deficient collection,

\footnotetext{
${ }^{160}$ This seems to be a solution to Cleitophon's complaint that Socrates' conversations only seem to amount to exhortations and are not productive of complete virtue ( $\mathrm{Pl}$. Clit. $408 \mathrm{~b} \mathrm{ff}$.).
} 
to be resolved by division. Phaedrus's opposition of rhetorical practice to "dialectic" imbued erōs into the very action of the dialogue. Erōs set their souls and dialogue in motion as it opened them to the philosophical search.

The dialogue on rhetoric grew from the seed of Lysias' shame, and whether writing was a necessarily shameful activity. This seemed to be refuted through the argument that politicians wish to be writers as well and believe the greatest good immortality - may thereby be attained. From this premise was developed the entire dialectical sequence concerning rhetoric: rhetoric without knowledge was shown to be ridiculous because use and practice would reveal such ignorance to be harmful; antilogic and dialectic were consequently demonstrated to be the form of speech by which the relation of speech and soul could be understood, as graced by knowledge of the kairos. The culmination of this dialogue on the art of speaking was itself finally placed in dialectical relation with Teisias' objection. The dialogue came full circle, ascending from Phaedrus's acknowledgment that the practice of rhetoric without knowledge fails to grasp what is fitting, to the grasping of the logical form of persuasion as fitting speech to soul in light of its true good, and then descending back down to practice and how a sort of persuasion can be achieved through probability, because the good of soul is implicit in the opinions of the audience.

Opinion, as that which seems to be good, is therefore closely linked to the erotic and dialectical unfolding of dialogue. It receives little direct attention in the Phaedrus, as compared to, say, the Meno, but usage of the words doxa and dokein are conspicuous enough that a rough outline of its nature and relation to rhetoric can be formulated. As a semblance of being, opinion shares in being, and provides a lesser sort of nourishment, 
but only shares - it is a partial concatenation of perceptions concerning a being (e.g., the "compacting" of the parts of beauty [251e4]) (cf. 247d1-5, 248b5). Dialogue proceeds through these semblances, persuading the interlocutor not by incontrovertible proof, but by a series of opinions which, true or false, are agreeable. Indeed, any frank dispensation of the truth is unpersuasive and no dispensation at all, for what is actually true is other than the semblance; the palinode showed how the pleasant charm of a seeming good induces forgetfulness. Only leading the interlocutor through a further series of semblances can bring him from the other to the one. Dialogue and dialectic must thus be conducted ad hominem if they are to be persuasive in a particular case and turn the soul from its opinions. ${ }^{161}$ This is the ultimate cause of Teisias' failure to achieve any real persuasion, for he neither directs his speech to the opinions of a single interlocutor nor refutes them, but instead allows the complex of common opinion to remain undifferentiated. He relies on the audience's agreement that it is, as a whole, ignorant, and consequently leaves that ignorance unresolved.

Socrates' own practice is thus set in sharp relief against Teisias, for he conducts his conversations in an excellently ad hominem manner at all times, and his conversation with Phaedrus is no exception. ${ }^{162}$ As Socrates later says, a farmer, "using his farming art, sows [seeds] in what is fitting" (276b). One might recall how Socrates did not refute Phaedrus's dear Lysias immediately, but over the course of two speeches, and did so in a form particularly suited to Phaedrus's tastes (235e-236a, 257a). Even then, Phaedrus was

${ }^{161}$ Aristotle makes similar observations with regard to dialectic in Topics 1.1-2, 10-12, 14. Contra Klein (27), who distinguishes dialectic and psychagogia in such a way as to deny ad hominem from the former. In what way, then, could dialectic really proceed? True, a "perfect" dialectic would treat simply on the nature of things and their natural "joints," but for reasons discussed below, no such dialectic is practically available.

${ }^{162}$ See Socrates' response to Polus's habit of arguing to a general audience rather than a single individual (Grg. 475e-476a). 
not persuaded by the admittedly beautiful palinode. It was sufficient to call into question Phaedrus's faith in Lysias, but not to lead him to philosophy, as the speech itself called for - that leading, Socrates said, was the task of the discussion of the art of speaking (cf. $257 \mathrm{~b}, 261 \mathrm{a})$. Socrates therefore could not claim to possess the erotic art on the basis of his speeches alone, but on his ability to lead the souls of his interlocutors to what is beautiful. In the terms of the noble rhetoric, the speeches most fit to hear are those which can actually turn souls towards a life dedicated to true excellence. While it is certainly questionable to what extent Socrates is able to persuade his interlocutors to philosophy, he is remarkably adept at leading them to refute themselves. What seemed to be the case can no longer be held to be true. Perhaps his erotic art lies simply in this, for the experience of aporia accompanies the experience of erōs, which is aroused to search not for what seems to be but what is. A complete vision or understanding of being is itself not necessary for Socrates' erotics, but what is necessary is showing how such a complete understanding is what is most needed by soul; Socrates would make lovers, not souls that are self-satisfied and complete, for such perfection cannot be the lot of human beings. ${ }^{163}$

Socrates therefore forgoes the title of dialectician, which was reserved for whomever "by nature is able to look to one and to many" (266b5-6). ${ }^{164}$ This complete technikos of speaking was shown to have an exhaustive knowledge of soul and speech, their relation to the other arts, and most importantly, what is kairos for soul and therefore

${ }^{163}$ Gadamer 1989 II.3.4.C.i (356-7, 359).

${ }^{164}$ In a striking contrast, Socrates tells Euthydemus that he "knows how to converse [dialegesthai] far better than I" (Euthd. 295d-e). Surely he could not mean that the flippant play of Euthydemus is of the same rank as the dialektikos who knows the nature of the whole? His compliment is ironic, but not necessarily false unless dialectic is supposed to be free of play and devoted solely to true statements. But it cannot be these things because it deals with the common opinion and the opinions of its interlocutors. If nothing else, Euthydemus' mixed success - his interlocutors are left dumbfounded but unpersuaded - is a powerful demonstration of the ignorance of the interlocutor, as well as the limits of such play in the face of opinions formed by experience of reality. 
humanity generally. Socrates cannot admit such complete knowledge, since he does not know whether he himself is one or many, and so follows the dialectician "as if he were a god" (266b). Collection and division are the way of "thought and speech," but Socrates has not and perhaps cannot grasp them in their entirety. For mere humans, erōs must lead the dialectic through its collections and divisions. ${ }^{165}$ The complete dialectician now seems to be inexplicable. Why does he speak and search for the whole if he knows the whole? As Socrates said: "but if we ourselves were to discover this [the truth], would we still care for something of merely human opinion?" (274c). The knower of truth has no need for opinion, but can simply act and be forever in the presence of the highest good. The knowledge of erotics implies something even more radical: if the dialectician aims to act, let alone speak, he must desire, and if he desires, it means he lacks something - but how can he lack something when he knows perfectly well how to achieve it? Either he is not an all-knowing god or there are some fundamental limitations that are disclosed but not overcome by knowledge; this is the same problem posed by the image of gods as beings that must ascend and descend and nourish themselves. Regardless, the dialectician must be able to explain, just as Socrates demanded of Anaxagoras and the rhetoricians, why, for the sake of what, he acts. The gods in the palinode do not speak, and "divine speech" remains hidden from Socrates (259d6). ${ }^{166}$ Socrates respectfully

\footnotetext{
${ }^{165}$ Weaver 21.

${ }^{166}$ The elusiveness of the divine logos is closely related to the two-fold nature Socrates ascribes to logos. It is through the logos that the nature of things is both revealed and concealed, as it clarifies beings only by their relation to other beings, and so being itself in relation to itself. This can be helpfully contrasted to the Christian Logos, exemplified in the Gospel of John: "In the beginning was the Word. And the Word was with God, and God was the Word. ... And the Word became flesh and dwelled among us ... full of grace and truth" (John 1:1, 14). Logos is the divine word through which one is led back to God and redeemed. It is one and whole and reveals the truth of the nature of creation. It has no fundamental division in itself. The image of Christ is far from the image of Pan - a demigod formed with a human body and the legs of a goat - that Socrates, far from believing himself to have found the "true way," attributes to the logos (Cra. 408b-d).
} 
departs from what appears to be the unassailable argument of the Eleatic philosophers, whom he elsewhere calls gods. ${ }^{167}$ Their ultimate dismissal of mere human opinion as "that which is not" leaves their own speaking unaccounted for, a perplexing imitation of the human by a god. ${ }^{168}$ Socrates' erōs thus dispels the monument of "the art of speaking" which he has created in the form of the dialectician, but not because it is wrong or false, for the unity which erōs seeks points to dialectic as the purification of erōs into the perfect motion through the "natural joints" of being. Rather, the monument of the art of speaking is dispelled precisely because it is a perfection that cannot be adequately grasped. ${ }^{169}$ Indeed, the complete motion of erōs is not simply the ascent that is overtly conveyed by the palinode, but also descent from perfection in order to understand how the being of beauty is found and produced in the life of a mortal. Socrates' erotic art, then, is seeking the kairos and the measure by which a human can live in friendship with the light of truth.

From this distinction between Socrates' erotics and dialectic simply, the noble rhetoric can be further distinguished. Like Socrates' erotics, the noble rhetoric is founded upon dialectic, but its attainment of artfulness is entirely dependent on the perfection of the dialectical understanding of soul. Grounded in the private knowledge of the object, the noble rhetoric lays claim to a rigor and development hitherto found only in medicine. It is accordingly subjected to a new technical expertise and standard, and if it is indeed capable of hitting upon basic truths concerning the soul, a hitherto unseen efficacy and reliability in persuasion (as Socrates said, even the lower aims of rhetoric will be better

\footnotetext{
${ }^{167} \mathrm{cf}$. Sph. 216a-c, Phdr. 258e ff.

${ }^{168}$ Parmen. fr. B1.30, B2, B8.50-2 [DK]; Melissus frs. B7-8 [DK].

${ }^{169}$ In the palinode, Socrates said that we mistakenly ascribe bodies to gods because we have "neither seen nor sufficiently contemplated a god," which is to say we are compelled to represent the perfection we seek by way of mixtures, images, and so are prone to error (246c-d).
} 
attained as a result of attaining the higher, i.e., a dialectical comprehension of the soul and its related principles [274a4-5]). ${ }^{170}$ The presuppositions of this knowledge carry further implications, as well as limitations. As Socrates argues with respect to the arts in general, art is devoted to the good of its object, and the development of rhetoric in accordance with what is fitting for soul shows it is no exception. Rhetoric is thus placed alongside the political art that Plato develops at length in the Statesman, each ultimately aiming towards and perfected by the cultivation of human excellence which, in its highest form, is the pursuit of wisdom. ${ }^{171}$ While this clear purpose is plausible for the statesman, it has hardly proven so for the rhetorician, whose prior success has been predicated upon widespread and fundamental disagreement concerning the nature of justice, the good, and the beautiful. Socrates' argument that rhetoric must be founded upon knowledge of human excellence is therefore a call for the radical reformation of its public and political practice, from the deliberation and legislation earlier mocked as flattery of the demos, to an art that can defend itself in terms of its beneficence, not only before a crowd, but also before the most searching of private inquiries. Unlike Gorgias' rhetoric, the public use of the noble rhetoric must proclaim and defend its utility for understanding and attaining what is good and just for its listeners and students. ${ }^{172}$ Socrates and Plato do not express this incredible change in the understanding of rhetoric, its nature and purpose, without misgivings. As discussed earlier, the determinacy with which soul was formulated in the

\footnotetext{
170 Yunis 2005102.

${ }^{171}$ In the Statesman, the knowledge of "for whom, when, and to what extent" one should use rhetorical techniques is attributed to the statesman rather than the rhetorician, thus subordinating rhetoric to the political art ( $P o l$. 303e-304e; also see $\mathrm{Lg}$. 937d-938c). The attribution of this knowledge to a rhetorician in the Phaedrus suggests that the discussion in the Statesman does not distinguish between the public and private rhetoric, which calls attention to the fact that the statesman must have persuaded himself as to when to use the art of persuasion.

${ }^{172}$ See Grg. 456a-457c, 460c-d, 517a ff.; cf. Men. 95c, Phlb. 58c. Socrates has misgivings about whether the good can ever be understood in its entirety $(R .506 \mathrm{~b}-509 \mathrm{c}, 546 \mathrm{a}-547 \mathrm{a})$.
} 
discussion of method is at odds both with the account of the soul given in the palinode and the erotic state presupposed by dialectic. The noble rhetoric must therefore proceed in a provisional manner, and so long as its art is not perfected, it will be susceptible to either error or abuse, for the rhetorician will be ignorant of the complete good of the soul. ${ }^{173}$ This sort of rhetoric, formulated as an "antistrophe" or "counterpart" to dialectic, is systematically explored by Aristotle in his Rhetoric, wherein he notes its susceptibility to abuse. ${ }^{174}$ The incompleteness of rhetoric thus returns to the problem raised and exploited by Teisias' probabilistic rhetoric, that the nature of the good and justice are inherently disputed because they are so dear to the individual soul, and so re-opens the basic questions with which political philosophy is concerned. In light of natural human ignorance concerning the whole, rhetoric acquires its nobility or beauty in the search for true knowledge that exemplifies what it is to be human.

The demonstration of Teisias' artlessness provides a useful way to explore Socrates' own artlessness. Both are artless speakers due to their ultimate ignorance of the soul, yet nonetheless attain a certain knack or prowess because of their understanding relative to their audiences. Here, the distinction between the public and private rhetoric reemerges, for there is no question that Socrates' ability to lead a private conversation by way of the opinions of his interlocutors, whom are wonderfully varied in nature, opinions, desires, and prejudices, is demonstrative of a far more profound and subtle understanding of soul than Teisias" superficial grasp of "what seems to be to the

\footnotetext{
${ }^{173}$ Yunis is for the most part correct to say that "there is nothing to prevent the rhetor from using his superior rhetorical skills, acquired by and buttressed with dialectical knowledge, for purely personal, corrupt, or destructive ends" (2005 105). But one must add the crucial caveat that this misses the highest end of rhetoric, excellence of the soul, which perfects the art. Yunis's rhetor would not be a truly artful one.

${ }_{174}^{174}$ Arist. $R h .1356 \mathrm{a}$. On the relation between rhetoric and dialectic, see $E N$ 1.4.1095a31-b13, Rh.

1.1.1351a1-11, 1355a6-29, Top. 1.1-2, 11, 14.
} 
majority." What has been called Socrates' erotic art or rhetoric of course means nothing less than engaging his interlocutor in philosophical conversation; Socrates is exercising himself in the collection and division of souls and kinds of souls that "are present before him," leading them to a fuller consideration of their own opinions, i.e., to selfunderstanding and therefore the pursuit of knowledge. Socrates thus commits himself primarily to the private rhetoric that consists of antilogic in its most basic form, the refutation of false opinion, which is not possible with Teisias' rhetoric.

Socrates cannot, however, use such rhetoric before a crowd, for the opinions of the crowd are only uniform at a superficial level, and will prove to be insufficiently uniform for eliciting complete agreement to each of the "small steps" taken over the course of a refutation, since the most precious things are the most disputable (263a-b, 273a6-b1). ${ }^{175}$ Socrates cannot isolate the individual opinions he requires in order to affect the necessary refutation. ${ }^{176}$ Moreover, humans do not desire aporia or find it attractive or pleasing, and seek refuge from it in a beautiful wholeness (251d-252a). These conditions allow a Teisias or Thrasymachus to seize hold of "what seems to be to the many" and rouse their passions, although this would be but a momentary madness and beauty, created "as if for a feast day" (276b). Socrates' unwillingness to proceed in "the way of Lysias and Thrasymachus" entails forgoing the effectual power he himself admits can be found in such rhetorical techniques and demagogically addressing crowds (260c-d, 268a). ${ }^{177}$ The return of the conversation to the court of law reminds the reader

\footnotetext{
${ }^{175}$ Aristotle mentions the ineffectiveness of syllogism and lengthy reasoning before a group $(R h$. 1.2.1357a8-22).

${ }^{176}$ In his trial, Socrates' singling out of his principal accuser, Meletus, only seems to confirm the prejudice of his jurors that he is "a clever speaker," boorish, and, as he describes himself, "a gadfly," and does little to persuade the audience of his innocence (Ap. 17a-b, 26e-27a, 30e-3la).

${ }^{177}$ See Prt. 335b-c.
} 
of the fate shared by Socrates and Palamedes, who, for the sake of themselves and their fellows were unwilling to debase themselves like men more beholden to the preservation of their bodies than the true justice that adorns the soul. Yet the court of law also recalls the impressive way by which the erös of the politicians has provided for their immortalization in law. The politicians, the flatterers of the many who draw on the talents of Lysias, Gorgias, Teisias, and Thrasymachus, have, however imperfectly, grasped the nature of soul sufficiently enough to fasten themselves in the memories of their fellow citizens through a unified, static, and constant code of law.

The legislator thus provides both the fixed meanings and comprehensive whole desired by the city that, so far as such static words and commands can produce some justice, will be fitting for it. Socrates' unwillingness to edify arises from the necessary and uncompromising pursuit of the true immortality, or rather eternity, to which erōs aims. But this leaves unfulfilled the possibility of an immortal logos attained through the gratification of lower parts of the soul that are aroused by bodily desires or love of honor. It is with this possibility in the background that Socrates and Phaedrus return to Lysias and the nature of writing. Socrates will not let his friend go until it is made clear how Lysias will have to write in the future, if he is to make speeches that are more beautiful than his clever word-play and that can lead Phaedrus towards philosophy in order to seek what is most fitting for his soul. 


\section{WRITING THE ETERNAL}

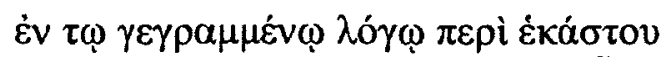

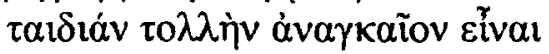 In written speech on any subject there is necessarily much play

Plato's discussion of the nature of writing arises out of two questions in Socrates' conversation with Phaedrus. First, what is noble and what is shameful in writing? This question was the impetus for the preceding dialogue on the art of speech, and to which Socrates now returns. Second, how may one gratify the gods in speaking or writing? This question was raised at the apex of the dialogue on rhetoric, and the noble rhetoric remains incomplete while it is unanswered, for the gratification of the gods is the highest purpose of rhetoric and speech. The two questions are addressed simultaneously and overlap to a significant extent. The question of noble writing depends on what is gratifying to god, and, inversely, what is gratifying to god will be revealed through the discussion of writing - as implied by the occurrence of that broader second question immediately prior to the discussion of writing. The criticisms of writing that will be advanced must therefore also be considered in relation to "speaking," legein, in the broader sense that encompasses both its oral and literary forms. It will be seen that Teisias' attempt to fashion a universal logos in the form of probability was an appropriate transition to the question of writing, for Plato will use the peculiar attributes of writing to develop a new and universal understanding of the logos itself that will act as the standard for noble and ignoble writing. In Socrates' Egyptian tale, Plato advances the harmful consequences of writing as the well-spring for a more robust interpretation of the written word, which ascends to an understanding of logos that comprehends orality and literacy, 
and so reflects the transcendent nature of being. Plato's playful writing and dialogue form incorporates this Socratic logos and ethic, but by writing it down he implies that Socrates' strictly oral rhetoric was limited in its manifestation of, and therefore limited in its participation in, what is eternal.

\section{An Egyptian Tale}

The truth about writing, Socrates says, is found in the ancient wisdom of Egypt, which tells of the advent of writing and its dissemination (274b-c). Socrates' intention in making the tale an Egyptian one is not clear, beyond the well-known age and piety of Egyptian civilization. ' It may be related to the myths of Typhon, alluded to at the beginning of the Phaedrus, the Greek gods fled to Egypt before the monster's wrath. ${ }^{2}$ If Socrates has this story in mind, his Egyptian tale would concern the flight from chaos or disorder, in which case the popular themes of Egypt's ancient wisdom and piety converge as the origin of divine order. As in the palinode, if truth is found in what is eternal, it can be fittingly represented as an ancient time out of which the present has followed in necessary accordance. But if modernity is considered a deviation from that eternal truth, a time in which that truth has been obscured if not lost and must now be recovered, there must have been an original moment of deviation from which the present condition followed. Socrates' Egyptian tale is concerned with how writing emerges from this original well-spring of modernism.

In Naucratis of Egypt, Socrates tells Phaedrus, there was a "god" and "demon" named Theuth, whose sacred bird was the ibis, a long-beaked water bird whose form the

\footnotetext{
'Plato's Critias recounts that the Egyptians considered the Greeks "always children" (Ti. 22b-23d). See also Hdt. 2.142.

${ }^{2}$ Apollod. 1.6.3.
} 
god assumed in hieroglyphs and paintings (274c). Theuth was a god of learning, invention, and art - an Egyptian Palamedes. Once, he went upriver to "the great city of the 'upper place' that the Greeks call Egyptian Thebes" in order to display his discoveries to the king, Ammōn, "whom the Greeks call Thamos" (the name, a compound of theos and $A m m \bar{o} n$, indicates that the Greeks did not believe the Egyptian name was a sufficiently clear mark of divinity) (274d). Ammōn, for his part, was known as the sun god and king of the gods, and was explicitly called the Egyptian Zeus by Herodotus, as well as "the hidden." The city of Naucratis was the Greek emporium on the Nile delta, and thus a site of acquisition and wealth-making, as well as of mixing local and foreign customs, whereby new knowledge and art would be disseminated. ${ }^{4}$ Theuth thus ascended to Thebes as a god of modernism, improving and correcting the customary ways. His sacred ibis represents this ascent from the formless change and becoming of water and the port city, rising into the air towards the sun and higher gods. As will be seen shortly, Theuth did not see his inventions as mere trifles for addressing the desires of a day, but for the lasting benefit and progress of the people. Socrates arranges these Egyptian symbols in accordance with his earlier stories, particularly the soul's winged ascent from mixture and human commerce to the "superheavenly place" where it is purified by divine and true knowledge (see esp. 249d). ${ }^{5}$

\footnotetext{
${ }^{3}$ Hdt. 2.42. On Ammōn as "the hidden," see Plu. Moralia 354c-d.

${ }^{4}$ Hdt. 2.178-9.

${ }^{5}$ The historicity of the Egyptian tale and its symbols is an important problem, but one that unfortunately depends on unavailable information concerning the depth of Plato's knowledge of Egypt, whether firsthand or by hearsay and writings (Strabo claims he traveled to Egypt after Socrates' execution in 399 BC [Strabo 17.29]). His references to Egypt in other dialogues are too general to draw any conclusions (e.g., Lg. 656d-657b, Phd. 80c-d, Phlb. 19b, Ti. 22b ff), and are further complicated by problems of Platonic chronology. It is a reasonable assumption that he read Herodotus' account, and the relation between the two gods in the tale betrays some passing knowledge of the features of coffin texts from the New Kingdom (1560-1070 BC), such as spells describing Theuth's examination of the soul at the behest of Ammōn-Re. Ammön did not have such a significant and royal place in the Egyptian pantheon before this period,
} 
Of the inventions that Theuth brought to Thamos for judgment, Socrates mentions five: "both number and calculation [logismos], geometry, astronomy, further both draughts and gambling [or: deceit, kubeia], and also letters" (274c). This particular array of arts would of course be of significant utility for the commerce in Naucratis. In the Republic, however, the first three arts are also part of the philosophical education of the guardians, valued for their capacity for drawing the soul towards the idea of the good in order to ensure the lasting order of the city. The arts' immediate pragmatic uses are propaedeutic towards this end. ${ }^{6}$ There too, calculation is the first and fundamental art, for it is the perception of unity that all knowledge and art consists of, and leads to intellection and what is in thought alone. ${ }^{7}$ Dialectic is conspicuously absent amongst Theuth's arts, even though it is the crown of the arts and the philosophic education in the Republic, ${ }^{8}$ and the essence of the art of speech here in the Phaedrus. "Most artful Theuth," as Thamos called him, only possessed the preliminaries of dialectic, and so did not possess knowledge of soul and what is truly useful. ${ }^{9}$ Neither did he seem to have possessed the poetic arts, e.g., harmonics, which are concerned with beauty and mad inspiration rather

although he is attributed his hidden nature in all periods (Budge 194). Theuth, by contrast, was one of the most ancient gods, at times even being assigned the role of creator god in relation to the power of the word and writing (Budge 183). Regardless of these concerns, Plato's Egyptian tale is intended as a tale, not history, and these symbols are used primarily in relation to the other symbols of the Phaedrus and Socrates' arguments, from which their meaning is ultimately derived.

${ }^{6}$ Number and calculation are used for counting troops, geometry for arraying them and surveying, astronomy for piloting ships and charting the seasons ( $R$. 522c-d, 525a-b, 526c-e, 527d-e). In the Laws, the same three arts are the basis of the education of "the free man" $(817 \mathrm{e}-818 \mathrm{~b}-\mathrm{e})$.

${ }^{7}$ Number and calculation are two aspects of the same art, as neither occurs without the other (see $R .524 \mathrm{c}$ e). This is indicated in the Phaedrus by the conjunction te kai, meaning "both number and calculation," i.e., both together.

${ }^{8}$ R. 531c-d, 532b-c, 533b-d. Nor does Theuth mention the geometry of solids, i.e., "the dimension of cubes and what participates in depth," which Socrates says has not yet been devised because it is useless, but is necessary to understand the nature of things, not least of all the movements of the heavenly bodies (Anaxagoras was in part exiled for the view that heavenly bodies are not gods but rocks [Ap. 26d-e]) $(R$. $527 b, 528 b)$.

${ }^{9}$ Yet dialectic must be present in the invention of letters, as Socrates shows in the Philebus, where Theuth grasps forms of speech in both their multiplicity and unity (Phlb. 18a-d). 
than sober utility. From its Egyptian origins, then, it seems that writing is an ugly utilitarian art designed to serve the pressing problems and desires of bodily necessity and luxury.

On the other hand, writing also follows the discovery of a two-fold instrument of play, "draughts and gambling" or "draughts and deceit," which certainly can be used for wealth-making, but only if the probabilities involved in draughts are understood or manipulated. Unlike the three preceding arts, which seek to override or escape chance for the sake of order and necessity, this fourth art embraces chance and what is unknown. Deception, it should be recalled, was an integral part of persuasion, and could only be performed on the basis of knowledge. So the same god that invented aids for humanity also invented games and deceit - his intention as a whole may have been serious, yet he nevertheless saw value in play. ${ }^{10}$ Writing, as the last of the arts, was therefore the culmination of what is serious and playful, necessary and probable, true and false. Theuth presented writing to Thamos as a supplement to the uncertainty introduced in draughts and deceit.

When Theuth displayed his arts to Thamos, he wanted them to be "passed on to the other Egyptians" (274d). He was a popularizer of knowledge, a democratizing god. ${ }^{11}$ Thamos did not criticize this sentiment, and responded as a king concerned for the welfare of the people. He examined each art presented by Theuth and "said whatever seemed to be noble or not noble" (274d-e). The hidden god apparently had much to say about each; this divine judgment originated from an unseen mind and knowledge capable of numerous manifestations in extemporaneous speech. Thamos enacted the prudent

\footnotetext{
${ }^{10}$ On the Egyptian incorporation of play into education, see Pl. Lg. $819 \mathrm{~b}-820 \mathrm{~d}$.

"Derrida 143-4.
} 
inquiry into what seems to be clear to Theuth, for whom the truth about the arts was hidden. In the case of writing, Thamos's criticism reveals how Theuth's intentions would in fact harm the souls of those using writing by keeping them enthralled to the earthly objects of sense.

This is first seen in Theuth's defense of writing, where he reveals his belief that knowledge can be simply manifested and transmitted as if it were an object: "this learning, $\mathrm{O}$ King, will produce Egyptians who are wiser and possess better memory, for I have discovered a drug [pharmakon] for both memory and wisdom" (274e). Theuth seems to make the same argument as the technician, who claimed knowledge of medicine from having read books about drugs and diets. Phaedrus rejected this argument (266d5$6,268 \mathrm{e} 2-4)$. But Socrates has Theuth claim something still greater: that writing corrects the condition of forgetfulness that threatens oral modes of learning, and is therefore an art by which all other arts may be acquired. Theuth thus believed writing to possess the greatest of powers - the wisdom and memory that Socrates previously said were the most needful things for soul $(247 \mathrm{~d}, 249 \mathrm{c})$. In this light, the dissemination of the arts appears to be philanthropic; writing, on Theuth's argument, would allow us to attain the most divine things and so gratify god. ${ }^{12}$ But Socrates' palinode also showed that the soul was not in the first place inspired by wisdom, but beauty; only when the desire for beauty and pleasure was purified into the pursuit and recollection of true beauty would knowledge

\footnotetext{
${ }^{12}$ In later sources, Theuth is credited with writing the Book of the Dead (lit. "Chapters of Coming Forth into Day"), coffin texts which included an assortment of spells to be used by the souls of the dead as a guide to the afterlife, and which also likely served as a moral guide for the living (Budge 343). The structure of that book, as a collection of techniques for living, comports with the technical and merely instrumental understanding of art characteristic of the rhetoricians. Plato once wrote that "If it appeared possible for [these things] to be written or spoken sufficiently for the many, what nobler thing could I have done in my life than this, to write what would be of great benefit for humanity and bring the nature [of these things] into light for all?" (Ep. $7.341 \mathrm{~d}-\mathrm{e})$.
} 
and wisdom emerge (250d-e, 253e ff.). It is Thamos's criticism of the superficial benefit of writing that reveals his prudence.

In his judgment of writing, Thamos claimed that Theuth, "being the father of letters," was led astray "on account of good intentions" towards the art he "engendered" (274e-275a). Paternal love blinded him to the true nature of writing. It is for this reason, it seems, "one man is able to engender the things of art, but another has the lot to judge [krinein] both the harm and benefit provided to those who practice [them]" (274e). Theuth's erotic impulse, his desire to redress the fundamental human separation from the wisdom that perfects the soul, has given birth to a solution for forgetfulness in the form of art, but the possibilities of that art do not conform to his hopes. The enthusiastic lover similarly clung to his perception of beauty as that which released him from his "birth pangs" (251e-252a). If Theuth wishes to learn the truth about his art, he must be able to judge or divide himself (krinein, "to judge," also means "to divide") and oppose himself, that is, put himself in dialectical relation. Indeed, Thamos told Theuth that what he believed about writing was "the opposite of what it is capable of," thus forming an antilogical structure out of which the true nature of writing could unfold (275a).

Thamos's objection was that writing in fact produces "forgetfulness in souls" rather than memory, and in doing so only gives an appearance of wisdom (275a-b). Lacking practice or use of memory, those who "trust writing" are only "reminded by foreign marks from without." Theuth, then, hoped to correct for the plasticity of the marks of oral discourse, that is, their instability and susceptibility to disagreement, for otherwise the differences between beings is difficult to retain $(263 \mathrm{a}-\mathrm{c})$. While this seems eminently reasonable, Theuth had apparently misjudged the nature of memory and 
therewith wisdom and knowledge, for those who rely on writing "are not reminded from inside themselves by themselves." The effect on memory from the over-reliance on writing is a familiar phenomenon, seen in Phaedrus's rote memorization and of Lysias' speech, but the distinction between external and internal reminding is less clear.

Thamos's argument seems to be an epistemological correlate of the ontological distinction developed in the palinode, between the transcendent beings themselves and their earthly manifestations to the senses. As such, the Egyptian tale continues to explore the problem of beauty and manifestation. Relying on external marks means seeing knowledge as the possession and schematizing of these sensible manifestations and reducing knowledge to what can be readily named and agreed upon, rather than seeing the inner cause of those manifestations. A soul that relies on writing is content with what is made manifest by these external marks. Similarly, this reliance on external marks construes memory in the conventional sense of a collection of determinate sensory objects or images within the mind, rather than in the sense suggested by the palinode the intellectual perception of the one form in which manifold perceptions share. Theuth believed the monuments sufficiently captured what they recall, and indeed, on this view, the difference between the two would be negligible. Theuth's implicit conception of knowledge is a natural consequence of its origins in commercial exchange and the "human concerns" that condemn philosophy as useless (249d). ${ }^{13}$ Rather than a drug for memory and wisdom, Thamos said that Theuth had only produced "a drug [pharmakon] for reminding" (275a). In saying this, however, Thamos conceded that forgetfulness is a problem, and his acknowledgment of writing's power to remind suggests that writing

\footnotetext{
${ }^{13}$ This resembles but is not identical with Alcidamas' criticism that writing is easy, common, and therefore ignoble (Alcidamas On the Sophists [Alcid. Soph.] 3-8).
} 
may yet be redeemed - so long as the user of writing perceives the dual nature of this pharmakon, as remedy and poison, a reminder and cause of forgetfulness. ${ }^{14}$ Just like the technician who learned that his drugs were not remedies in every case, the user of writing must learn the measure for judging its use. ${ }^{15}$

Thamos makes a second criticism of writing, concerning its political effects. Having produced forgetfulness rather than memory and wisdom, writing "will furnish to those who are learning an appearance $[d o x a]$ of wisdom, not its truth" (275a). The memorization and mere recounting of words as if they simply expressed the truth is not, of course, exclusive to writing, as both Phaedrus and Socrates recall "having heard" a common opinion or pithy expression, something that's merely in the air $(235 \mathrm{c} 2-4,260 \mathrm{al}$, $274 \mathrm{cl}$ ). Thamos must mean that this problem in oral discourse is exacerbated by the written word; reading and writing seem to inculcate a different approach to words and their meaning. Students are equipped with an appearance as if it were clothing, much like the sophist Hippias, whose ostentatious dress was a testament to his vanity and superficiality (compare Socrates' jibe at Phaedrus's own "borrowed ornaments" [239d]). ${ }^{16}$ Without a "reminding from within," an inner core, the fixity and rigidity of writing will paradoxically produce students who float on the realm of pure showing and

\footnotetext{
${ }^{14}$ The duality of writing as a reminder may coincide with the two forms of writing that Herodotus says existed in Egypt, the hieratic ("sacred" or priestly) and the common (Hdt. 2.36). For reasons that are made clear later, Plato would likely consider it impossible that writing could ever perform the higher reminding exclusively.

${ }^{15}$ Jacques Derrida's well-known essay, "Plato's Pharmacy," makes much of the dual meaning of pharmakon, as conveyed by the English word "drug," but does not acknowledge that Thamos's play on this duality implies that there must be a measure by which the conditions for its use may be judged. Instead, each side of the pharmakon is merely the assertion of one difference against another (Derrida 114-5). Indeed, Derrida's essay throughout shows a refusal to engage in conversation with Plato concerning the power of writing to remind, i.e., to lead the soul towards any understanding of the nature of things beyond what is believed to be the meaning contained in words, and notably omits any discussion of the art of rhetoric, which showed the need to possess some knowledge of the nature of things in order to communicate, let alone persuade artfully (see, e.g., Derrida 121-4).

${ }^{16}$ Hp. Mi. 368b-c; Prt. 315c.
} 
externality, such that they would be unable to differentiate, even in principle, opinion and knowledge. One merely collects objects that everyone can agree about - which was Phaedrus's first opinion concerning rhetoric. Wisdom does not consist, for Thamos, in the memorization of external marks, but must lie, as is fitting for a hidden god, behind or in-between those marks, in the background as it were.

From the effects of writing on the individual soul also follows a broader problem when those souls interact with the community. Thamos charged that students would become stubborn and vain, believing that they possess wisdom and do not therefore have anything to learn. They would be "seeming-wise" (doxosophoi) rather than truly wise (275a-b). Believing that knowledge and wisdom consists of memorizing external marks, the only proof of it would be similarly external - victory in verbal contests, known as eristics (from eris, "strife"). Socrates diagnoses the political consequences of this conceit more fully in other dialogues, ${ }^{17}$ although reverberations of it have been seen in the Phaedrus in the urbane speeches and Teisias' forensics. In the urbane speeches, disagreement does not produce doubt and a search for knowledge, but resort to common consent, while Teisias believes that justice is entirely conventional and consists of nothing more than the verdict. On the principle that the nature of the individual will affect political relations, Thamos seems to imply that greater congeniality will obtain where the individual soul does not rely on writing and is consequently open to learning because he does not presume to know, i.e., knows it is ignorant.

\footnotetext{
${ }^{17}$ A memorable example is the pretension of the politicians, poets, and artisans, who all believe themselves to know more than they do and have become proud $(A p .21 \mathrm{~b}-22 \mathrm{e})$. In the Theaetetus, the opinion that perception is knowledge, i.e., relative to each and every living thing, is said to produce a solipsistic ethos that is destructive of custom, law, and any belief in natural and true justice beyond instrumentality (171d ff.). A similar view produces the opinion that justice is merely what is agreed upon $(R .358 \mathrm{e}-359 \mathrm{~b})$. In the Gorgias, the eristic manner of argument that prides itself for its ability to persuade the crowd is criticized for submitting itself to the judgment of the mob (448d-e, 471e-472d).
} 
Socrates concludes his Egyptian tale without mentioning either a rebuttal by Theuth or whether Thamos reached a final verdict. ${ }^{18}$ If Thamos's judgment of writing was entirely negative, though, Socrates would have merely returned to the same conclusion of the politician who slandered Lysias, that all writing is shameful $(257 \mathrm{c}$, 258d). Instead, Theuth and Thamos have staked out the advantages and disadvantages of writing (and, implicitly, oral discourse), as well as the possibility of a middle way. It cannot be assumed therefore that Theuth and Thamos expressed the final position of either Socrates or Plato on writing. The Egyptian tale does, though, broach the question of why Socrates did not write yet Plato did, which is one of the few ways that Plato draws attention to a difference between himself and his teacher. The consideration of this problem in the following pages will be restricted to the particular function of the question in the Phaedrus. ${ }^{19}$

Phaedrus is incredulous about Socrates' Egyptian tale. He repeats his old concerns about myths and the authority of its source: "how easily you make speeches from Egypt or whatever place you wish" (275b; cf. 229c, 235c). Socrates swiftly rebukes him for his modernism and superficial urbanity, reminding him that

[s]ome said the first prophetic speeches arose from an oak in the sacred [place] of Dodonian Zeus. Some men at that time, inasmuch as they were not wise just as you moderns are [lit. "young ones," neoi], listened to the proclamations of oak and rock on account of their simplicity [euettheia], if only they should speak the truth; but perhaps it makes a difference to you who it is that is speaking and where he is from. For you do not consider only whether it holds in this way or another. (275b-c)

\footnotetext{
${ }^{18}$ Another possible verdict concerning writing, attested to in the Laws, is the use of strict legislation to prohibit innovation, as was done in the mimetic arts (656d-e).

${ }^{19}$ A full consideration of why Plato wrote and Socrates did not would need to incorporate similar discussions in several other works, such as the Laws, Phaedo, Republic, and Plato's letters.
} 
Phaedrus's all too easy skepticism must be refined so that he does not accept the facts of time or place or one's opinions concerning the person speaking as sufficient for truth or knowledge. The reason for this is clear, as Phaedrus simply shifts the burden of thinking and discovering the truth to trusted sources, that is, to his prejudices. Speech and thought aspires, Socrates seems to say, to a truth and universality beyond the vicissitudes of time or place. And even if the sources that Phaedrus trusts really are trustworthy, this does not mean that he has understood them. Just as Thamos prophesied, the moderns will suffer from the detrimental effects of their "trust of marks from without" and ignorance of the reminding from within. Socrates seems to have put Thamos's words in another form, as if the Egyptian god moved to a place Phaedrus finds more familiar and perhaps more trustworthy. ${ }^{20}$ In a similar appeal to the familiar, Socrates borrows the proverbial phrase "oak and rock" from Homer. ${ }^{21}$ Socrates, moreover, began his Egyptian tale trusting that "the forbearers alone know the truth" (274c). Socrates himself seems to rely on the familiar and trusted to make his point that one should only trust true speech; he has not abandoned the ad hominem character of dialectic. ${ }^{22}$ His praise of the simple folk at Dodona is ironic. How could they know whether oak and rock had told them the truth if they did not already know it or could interpret it from their words? Socrates himself said at the beginning of the Phaedrus that "the country and the rocks do not wish to teach me anything, but the human beings in town do" (230d). It is therefore difficult to reconcile Thamos's warning with Socrates' invocation of Dodona, for the latter trusts entirely the

\footnotetext{
${ }^{20}$ Herodotus reports a story that a priestess of Ammōn who fled Egypt established the oracle at Dodona (2.54-8). Ammōn is mentioned alongside Delphi and Dodona in Plato's Laws (738c).

${ }^{21} \mathrm{Hom}$. Od. 19.163. Penelope demanded to know the origins of her disguised husband, since he "was not [born] from oak nor from rock." Socrates, though, seems to use the proverb to the opposite purpose of freeing speech and thought from particular circumstances. He again uses it in this way in the Apology, demanding that the merits of the case not be judged by the personal circumstances of the defendant, but by its truth (34d).

${ }^{22}$ See Ep. 7.344d-e.
} 
external marks by which a prophecy or oracle is delivered. Perhaps Phaedrus should likewise examine more carefully the apparent truths that have been uttered under the plane-tree - the presumed clarity of the urbane speeches was also said to be "simple" (242d). Phaedrus should also interpret for himself and ask questions about Thamos's judgment of writing when Socrates calls the god's words a "prophecy" (275c7-8).

\section{Socrates and Plato}

Following the Egyptian tale, Socrates interprets Thamos's criticisms of writing and continues to develop them in contrast to oral discourse. The indirect dialogue between Plato and Socrates thus begins in earnest. Socrates begins by making clear his reservations about the "simple" ancients who listened to oak and rock:

if someone leaves behind or receives an art in letters, supposing there will be something clear and firm from letters, he will be full of simplicity [euêtheia] and really ignorant of the prophecy of Ammōn, supposing words that have been written are anything more than reminders for the one who knows about the things that have been written. (275c-d)

Ammōn's prophecy for all the arts that are written down - Socrates says "an art in letters," not just the art of writing - arises from the assessment of writing at its origin. In dwelling on these mythical origins, Socrates is able to return to and uncover the questionable nature of writing. The power of writing to remind is only developed in light of its questionable nature, and this questionable nature is only visible as the posing of a problem, a deliberation between two opposing ways. In fact, only if writing can be seen in its duality, as remedy and poison for memory, are its highest powers for recollection possible, for this duality keeps open the distinction between eternal being and earthly manifestation. If writing is seen as simply a remedy on the one hand, or a poison on the other, it will never really recall being in its transcendent nature: if writing is only a 
remedy, one will believe that it says what is "clear and firm," although it only points to other phenomena, rather than what is actually truly clear and firm, namely eternal being; and if writing is only a poison, which is the impression Thamos may give, one will be closed off to its highest power. ${ }^{23}$

In order to explain how it is that writing encompasses both reminding and forgetfulness, Socrates draws an analogy to painting. This appears at first to be a curious analogy, given that the latter is a strictly visual medium of imitation, while writing is a visual imitation of the aural medium of speech, i.e., even further removed from the object of imitation. Early forms of writing, however, particularly the Egyptian hieroglyph, were predominantly pictorial and indicative in the simple manner of painting. Socrates says that painting and writing share a power that is deinon, both "terrible" and "clever," to make what is silent and dead appear alive, animate, and capable of speech (275d). ${ }^{24}$ It is on the basis of this indicative function of writing that Socrates establishes its defects. He identifies three defects in particular: endless repetition; the inability to adapt to its audience; and the need for assistance.

With regard to the first defect or property, Socrates says that the "offspring" of painting stand as if alive but remain silent before questioning. Socrates' use of "offspring" is not merely a rhetorical flourish to contribute to the image of seeming-life, but shows the involvement of a human being; art is not a dead technical or mechanical

\footnotetext{
${ }^{23}$ An adverse consequence of this is "misology," which Socrates diagnoses as the belief that there is nothing sure in argument or logos, such that there is no rest in anything. Rather than look to himself for the source of error, the misologist blames the logos itself ( $P h d .89 \mathrm{c}-\mathrm{d}, 90 \mathrm{~b}-\mathrm{d}$ ). A useful modern example is found in Derrida's criticisms of "logocentrism" and belief that all speaking is writing, meaning the assertion of one pharmakon against another: "The eidos, truth, law, the epistēme, dialectics, philosophy all these are other names for that pharmakon that must be opposed to the pharmakon of the Sophists and to the bewitching fear of death." The pharmakon itself has no essence or eidos and so its assertion against another pharmakon ultimately finds no ground (Derrida 124-6).

${ }^{24}$ Theuth's Book of the Dead contained spells that were believed to reanimate the $B a$ (loosely, the soul) of a human being after death (see note 12 , above).
} 
process, but caught up in the purposes and actions of a living organism, i.e., the motions of soul or erōs. As Socrates will show, the products of art are akin to the body and in constant need of soul for their life and motion. Similar to painting, "words" (logoi) seem to speak "as if thinking [phronēsthai]," but if asked a question, "they only point forever to the same thing" (275d). The offspring of each art refers to something else, but because it fixes it in place and cannot speak of it in any other way, it betrays its appearance of life and motion. Thinking is therefore not reducible to fixed and unchanging words or images, but entails moving through the various relations and appearances of its object, such as in the way Thamos was able to say "many things" about each art he surveyed. The fixity of the beings themselves, "whole and simple [hapla] and unchanging," cannot be replicated in speech $(250 \mathrm{c})$. It should be noted that Socrates does not yet restrict this warning to written words, as some commentators suppose, ${ }^{25}$ since he speaks only of logoi (275d7). It is evident that repetitious utterances are also a problem when they are oral, such as when Phaedrus asked Lysias to repeat his speech over many times so that he might memorize it, as if he was learning something, or when the three monologues were delivered in the first half of the Phaedrus without subsequent examination. Without continuous discussion, those words are no more conducive to thinking than written ones. ${ }^{26}$ Even the following two defects, which seem to be inherent to the written word, are as much defects in oral discourse.

The second defect is that, whenever written down, "every speech is rolled out everywhere to those who give ear, and so in the same manner to those it is not fitted for, and it does not know to whom it must speak and to whom it must not" $(275 \mathrm{e})$. The

\footnotetext{
${ }^{25}$ De Vries 252n ad loc; Hackforth ad loc.; Yunis 2011 230n ad loc.

${ }^{26}$ Cf. Ion 530b-c.
} 
written word assumes every soul it addresses is the same and what is fitting for one is fitting for all; there is no grasp of the kairos, the opportune moment, which is the keystone of the art of rhetoric. This is not entirely misguided, since "all soul" was said to be nurtured by what is the same - the true knowledge of being, which is fixed and unchanging and thus universal. Writing may then presume to give to all the complete and final truth by virtue of it addressing something found in every soul. As was the case with Teisias' probabilistic forensics, what is lost is the ability to address the various types of soul by taking into account and responding to their particular opinions and desires. This forgoes the ad hominem of Socrates' dialectic.

The third defect of writing is that such a static, unresponsive, repetitive, and insensitive form of speech is always in need of assistance from its "father" when it is abused (275e). The written text is always a child, whose thought is furnished by a parent able to respond to the particulars of a question, supplement its fixed words with further words, and judge the nature of its audience. This is the danger of attempting to learn from books alone, rather than thinking for oneself - one becomes a rhapsode forever fastened and enslaved to his source as if by a chain (277e). ${ }^{27}$ Socrates thus sets up writing as the negation of oral speech, dead rather than alive, fixed rather than in motion, oracular rather than rhetorical, and beholden rather than free. It cannot therefore possess the logographic necessity that produces speeches that are like "living animals" $(264 c) .{ }^{28}$

Socrates criticizes writing as if what is said is taken to be self-evident, but is it not possible for the same text to be interpreted in different ways, rightly or wrongly, as were the written prophecies of the Pythia and the Sibyl? A reader must, after all, use moving

\footnotetext{
${ }^{27}$ Ion 533d-e, 535e-536d.

${ }^{28}$ Klein 11.
} 
oral discourse to give meaning to the written marks. Socrates is therefore as much critical of a manner of receiving the words and an understanding of the nature of logos as he is of writing. As noted, his criticisms of writing are also applicable to oral speech performed in a similarly fixed and unresponsive manner - which is precisely the manner preferred by Phaedrus. In light of this unthinking manner of speaking, it is not without irony that Phaedrus agrees to Socrates' criticism of writing with the comment, "you speak most correctly [orthotata]," rather than his usual, "it is likely." Phaedrus understands the warning about the rigid nature of the written word as if it is itself orthos, "straight" or "right" or "correct" (275e6; see also 275c3, d3). Phaedrus acts as if he were the white horse that obeys without question the words of the charioteer (253d-254c).

The rigidity of the written word nonetheless provides a springboard that allows Socrates to see "another speech [logos], a legitimate brother of this one" and "the manner by which it comes to be, and how much better and more capable [or: powerful, dunamis] it is by nature than this one" (276a). This confirms that the problem is between two forms of logos, rather than oral and literate logos simply. ${ }^{29}$ The legitimate logos possesses properties of both the oral and written; indeed, it is only on the basis of the properties of writing outlined above that Socrates can formulate an adequate image of the legitimate logos. It is "that which is written with knowledge in the soul of the one who learns, on the one hand able to protect itself, and on the other knowing [when] to speak and be silent with respect to those it must" (276a). Writing has become an analogy for true knowledge. Socrates, having introduced the properties of fixity and reminding, is able to show Phaedrus, on the one hand, the difference between the motion or plasticity of words and meaning, and, on the other, the fixity and self-same nature of knowledge.

\footnotetext{
${ }^{29}$ Nehamas and Woodruff xxxv-xxxvii. Compare note 25 above.
} 
In the palinode, Socrates described "true knowledge" as "not that to which generation is present, nor what is different in the different things we now say are, but the knowledge that exists in the presence of that which really is" (247d-e). The legitimate logos is the "reminding from within" that Thamos spoke of; "writing" is thus exonerated when it is in the soul rather than just "alien marks from without."

But it is difficult to conceptualize what writing on the soul really is, as the image is a seemingly impossible compound: a reminder or mark that always points to the same thing as well as being a fluid discourse which changes according to its audience. This "writing" therefore transcends the visual analogy of painting, which would give it the clear properties of a particular sensible object, and instead stands in the soul like the beings themselves, "colorless and shapeless and intangible" (247c) - writing ceases to be a physical object or possession at all. Phaedrus interprets this enigmatic condition of soul in the terms of logographic necessity: "you mean the living and ensouled logos of the one who knows, of which the written is an image and would justly be said to be some phantom [eidōlon]" (276a; cf. 264c). In their words alone, Socrates' and Phaedrus's interpretations of the legitimate logos confound one another - the soul which is written on possesses yet another soul, and the writing on the soul would be but a phantom of yet another speech. The legitimate logos resists any singular determination, either by sight or by speech. Plato can only bring forth the nature of the legitimate logos through this confounding, from in-between the speeches as it were. Phaedrus does well, then, to see that Socrates' use of "writing" transcends writing in any conventional sense. In seeing how the meaning of writing can encompass these opposing senses, he perceives the manner in which the living logos emerges from Socrates' dichotomy of oral and written. 
The "oral" aspect of the logos is portrayed as that which sets beings in motion, characteristic of Lysias' disordered word play. The "written" aspect fixes being, brings it to rest, characteristic of Socrates' first speech which presumed to possess such clarity of speech that could bound the disorderly world. The logos as a whole, if it is whole, is the manifestation and perception of transcendent being, and the human being is that animal that, holding the logos, "has seen the truth" (249b).

Out of Phaedrus's distinction of the living logos from its phantom, ${ }^{30}$ Socrates develops two kinds of writing. He uses the analogy of farming to imbue the life of the logos into the previously dead husk of writing, showing what might be the respective "offspring" of the legitimate and illegitimate logoi. Speeches are now "seeds" that a "sensible [nous] farmer cares for and wishes to become fruitful," and therefore natural and generative rather than the artificial and sterile products of painting (276b). Art is here directed to cultivating the human being rather than producing artifacts. Would this sensible farmer, Socrates asks Phaedrus,

in seriousness plant these seeds in the summer, in a garden of Adonis, and rejoice when he beholds [theörein] them as they become beautiful in eight days, or would he only do these things for the sake of play [paidia] and a feast day, if he would do them at all? But for those things which he was serious about, would he make use of the farming art, and scatter seeds in what is fitting, glad that what he sowed would grasp perfection in eight months? (276b)

The use of seeds for a beautiful feast day is the rhetoric and writing preferred by Phaedrus, who, like a cicada, would have only that speech that delights and gratifies him. Socrates seems to have in mind those speeches that are directed to the pleasing of its audience at all times, as if there were an eternal summer on this earth, without regard for

\footnotetext{
${ }^{30}$ Many have noted that Alcidamas anticipated Plato's criticism of writing on this very point, but the above considerations indicate that Plato in fact envisioned a "living logos" beyond oral and extemporaneous discourse (cf. Alcid. Soph. 27-8).
} 
a more fitting or natural purpose. Recalling that Eryximachus directed his medical art towards this end, it would seem that this problem emerges from an underlying ethos that is insensitive to the cultivation of the soul, and goes beyond the particular form of speeches. Socrates does not preclude the sensible farmer from using his seeds for "feast days," e.g., for the celebration of the harvest and its patron gods. The soul longs, after all, for the feast where it might likewise "behold" the cause of its longing (247c-e). But this vision cannot be the only end of the soul, for even the gods only feasted at the apex of their ascent, after which they could continue their cosmic cycle; for mortals, that feast is but a moment, and dwelling in ecstatic beauty only hides the true nature of things. The superheavenly beings as beheld in their utter clarity - and Plato only uses the verb "behold" (theōrein) four times, twice in reference to those beings and twice in reference to the flowers in the gardens of Adonis - must be perceived in the things "that come to be" and incorporated into practice $(247 \mathrm{c} 1, \mathrm{~d} 4,276 \mathrm{~b} 4, \mathrm{~d} 5)$. They must be, as it were, planted in a "serious" way and cared for so that they might flourish to their full nature, what is "fitting," rather than forced into what is merely believed to be beautiful. ${ }^{31}$

Socrates now specifically brings the analogy to bear on writing. He first has Phaedrus agree that a man who has "pieces of knowledge" of "what is just and beautiful and good" must be "sensible" (or: intelligent, nous) with his seeds (276c). Apparently, one cannot have knowledge without being intelligent with respect to the object in question, which in this case is what is fitting for soul; knowledge is purposive, as

\footnotetext{
${ }^{31}$ The "gardens of Adonis" were pots and boxes used to force plants so they might quickly flourish, and would be discarded after use in festivals (de Vries 253n.276d3, Yunis 233n.276d2-3). These festive boxed plants are likely named on the basis of the myth, reported by later mythographers, that Adonis was born out of a smyrna tree (from which myrrh flows) and then hidden in a chest and given to Persephone. Once the box was opened, Persephone delighted in the infant's beauty and refused to part with him (Apollod. 3.1835; Hyg. Fab. 58).
} 
Socrates pointed out a number of times in the discussion of rhetoric. This man who possesses some knowledge of these things will not be serious about writing, because these words cannot help themselves "and are unable to teach sufficiently what is true." This new criticism of writing is closely related to writing's inability to adapt to different souls, but does not preclude writing so long as it receives some assistance or is otherwise able to accommodate its inability to simply manifest the truth.

This knowledgeable writer will instead "sow and write the garden of letters for the sake of play [paidia]," and this play will truly be "altogether beautiful," as Phaedrus observes (276d-e). Whenever this man does write, he will be "storing reminders for himself, when he comes into forgetful old age, and for everyone who shares the same track, and he will be pleased when he beholds their [the seeds'] tender growth." Thamos's judgment of writing is now shown to have been not entirely negative, for the function of "reminding" that he identified has become an instrument for planting and growing "pieces of knowledge." The playfulness of the actual writing, then, is directed towards the serious purpose of helping others recollect the nature of things that their souls possessed before being planted in a body, the success of which would be a testament to his own grasp of their nature and his own art. The knowledgeable writer writes for the purpose of education (paideia), yet it is a nuanced account of education that incorporates all of the preceding concerns about reminders being mere "phantoms" and inducements of forgetfulness, the fixity and insensitivity of writing, and most important for the character of the student, the production of a "seeming wisdom." Once these defects have been recognized, Socrates is willing to allow that writing may be useful for education and real thinking. 
Socrates is careful to distinguish the play of the serious farmer and writer from the conventional understanding of play as mere entertainment and pleasure-seeking. He contrasts the knowledgeable writer's play with those who spend their time drinking in symposia, recalling Epicrates' hosting of Lysias and Phaedrus (227b). Socrates himself, though, is a frequent attendee at symposia and known for his prodigious drinking ability. ${ }^{32}$ How, then, are we to understand his present slighting of symposia? Is he really condemning himself, since there is no evidence that he ever amused himself by writing? It does not seem to be the case, since there is much evidence that he conducted himself in a playful manner at all times, either in symposia or elsewhere, filling his conversation with levity and irony, often telling jokes and amusing stories or examples, and only rarely falling into quiet reverence and contemplation. ${ }^{33}$ Phaedrus describes the noble writer's play as "mythologizing about justice and the other things you mentioned," much like how Socrates mythologized about justice, beauty, and the good, earlier in the Phaedrus and in the Symposium. Indeed, the "altogether beautiful" writing seems to be modeled after his own oral practice and constant sobriety concerning the highest things while others descend into the frivolity he only plays at. ${ }^{34}$ Even if the historical Socrates was no poetic mythologizer, and his great myths are but dramatic inspirations wrought by Plato, Socrates' famed irony is akin. If nothing else, Plato's mythologizing is a beautification or encomium of Socrates' ironic manner, a showing out or display of "the most divine and greatest images of virtue" inside him. ${ }^{35}$ There is little reason to suppose that the writer who prefers to play in his writings could not imitate Socrates' manner in symposia

\footnotetext{
${ }^{32}$ Xen. Smp.; Pl. Smp. 176c, 214a.

${ }^{33}$ E.g., Phd. 84b-c, R. 509b, Smp. 175a-b, 220c-d, 221 e.

${ }^{34} \mathrm{Cf}$. the conclusion of Plato's Symposium, when all others are drunk or utterly exhausted (223b-d).

${ }^{35}$ Smp. $221 \mathrm{~d}-222 \mathrm{a}$; see also Ep. 2.314c. See Friedländer $1.137 \mathrm{ff}$.
} 
or appreciate the opportunities that symposia present for planting seeds. ${ }^{36}$ But for a valetudinarian like Phaedrus, Socrates' straightforward distinction between the play of the writer and the play of the drinker usefully directs his moderation towards a more serious use of speeches. Socrates does not attempt to disturb Phaedrus's bodily moderation while praising the erotic mania of philosophy.

Socrates now turns Phaedrus's attention to the serious business that the knowledgeable writer attends to, which must be clarified in order to maintain the distinction between his play and mere frivolousness: "it is much finer [or: nobler, kalliōn] to become serious concerning these things" (276e). He thus guards against speeches about justice, beauty, or the good that are playful without seriousness, that is, without the intention of learning about these things. Teisias' approach to justice as merely a form of rule that citizens must abide by and placate, rather than a condition of soul, would be one example of this lack of seriousness. Such superficiality seems to be particularly problematic for literary men of means, like Phaedrus, who do not face the life-threatening necessities of a litigant - at least until their frivolous play brings them into conflict with the law, as Phaedrus saw with his desecration of the Eleusinian Mysteries. Socrates says that at the heart of this seriousness lies dialectic, which is the nature or perfection of rhetoric. The serious "farmer" of the "garden of letters"

makes use of the dialectical art [technē], taking hold of a fitting soul, plants and sows speeches with knowledge, which are sufficient to help themselves and the one who planted [them] and are not fruitless but have seeds, from which others may grow in other characters [éthoi] that are sufficient to make this one forever immortal, and make the one who has it happy to the greatest extent possible for a human being. (276e-277a)

\footnotetext{
${ }^{36} \mathrm{Lg} .637 \mathrm{~b}$ ff., Xen. Mem. 2.24-6. It is possible that the present passage in the Phaedrus also serves to mock Isocrates' valetudinarian advice to Demonicus with respect to symposia - assuming that Isocrates himself did not also adapt his words to his audience (To Demonicus [Isoc. 1] 32; cf. McAdon 27).
} 
Socrates reminds Phaedrus that the use of dialectic entails adapting speeches to souls, which writing was said to be incapable of, even though their discussion of rhetoric concluded that someone who writes without adapting his speeches would never "speak with art" (272a-b). Writing, if it is to aspire to this highest form of speaking, must somehow find a way to not just say the same thing always, but to communicate different things to different readers, or bring each reader into the same position so that they can all be addressed in the same way. This is the knowing way by which speeches must be planted and sowed, which, being adapted to the soul of the audience, will be beneficial (see 270b). These speeches will therefore not be complete or perfect themselves, but only in light of what they grow towards - the writing on the soul. Writing and speaking follow the same principle, which is to remind and lead the soul towards knowledge.

The immortality of the logos is consequently conveyed through the organic imagery of planting, growth, and reproduction, as opposed to the immortality of the gods, who forever moved as pure souls without bodies throughout the cosmos. Adrasteia's planting of souls in bodies is thus reenacted here by the knowledgeable writer, whose relation to his students and readers is a microcosm of the necessity that sets the souls of mortals onto their cosmic journey. That the logos is true, planted with knowledge, will be evidenced by the return of those souls to the superheavenly place, that is, by the development of their own understanding of the nature of things. The educator teaches by leading his students to think and discern the nature of things for themselves, such that the immortality of the logos is derived from each soul's perception of the beings themselves. The logos that is reproduced and immortalized is therefore not a set of speeches, fixed words, laws, dogma, or doctrine. Rather, the "living logos" and "writing on the soul" is 
knowledge embodied in the student's own life. If Plato is himself capable of producing such writing, he will have to do so by reproducing the living logos in his readers. ${ }^{37}$

Before Socrates can describe a truly noble written rhetoric, a Platonic rhetoric, he first wishes to recapitulate the results achieved thus far. Socrates has elicited Phaedrus's agreement to the limitations of writing, its status as a plaything in comparison to the writing on the soul, and that the possession of the art of dialectic is integral for the writer both to grasp the nature of things as well as to reproduce this living logos in his students and readers. From these things, "we are now able to distinguish those things, Phaedrus," that is, the "reproach of Lysias concerning his writing of speeches, and the speeches themselves, which were written with art and [which] without art" (277a-b). The question of artfulness appears to Socrates to have been sufficiently addressed for their purposes, but he is compelled to recapitulate those earlier results as well, on account of Phaedrus's forgetfulness (277b4). For now, he gladly steps in to serve as Phaedrus's reminder.

Again, the man who wishes "to take in hand the race of speeches with art" must first know the truth about what he speaks or writes, "defining everything [pan] by itself" (277b). Having defined these, he must know how to "cut according to [their] forms [eidē] until [he reaches] what cannot be cut." Then, he must see "the nature of soul" in the same way, and "discover the fitting [to prosarmotton] form [of speech] for each [soul] by nature," from which he can then "set and arrange the speech," giving "panharmonic and multicolored speeches to a multicolored soul," and simple speeches to a simple soul (277b-c). As in previous recapitulations, Socrates reformulates the conditions of artful rhetoric rather than repeat them verbatim, with a few suggestive

\footnotetext{
${ }^{37}$ Benardete writes that "The peculiarity of Plato's art consists in his showing the nature of philosophy in general while showing the impossibility of deducing from its nature the nature of a philosophic argument in particular" (2).
} 
variations. The first is the emphasis on the particularity of the knowledge demanded, where "everything" (pan) is defined, without mention of the synoptic view of "the whole" (to holon) implied by the Hippocratic method (270c). Indeed, it is not clear whether it would be possible to define, "bound" or "limit," the whole in the same manner that its parts must be limited in relation to one another insofar as they are distinct parts. ${ }^{38}$

The second variation is that Socrates for the first time distinguishes the kinds of speeches and souls, having hitherto only indicated that it is necessary to do so (cf. $271 \mathrm{~b}$ ). The two broad kinds are "multicolored" (poikilos) and "simple" (haploos), the former having been used to describe Lysias' speech, and the latter one of the two poles of Socrates' soul (haploos and polueides, 230a). Socrates has taken into himself, or perhaps found in himself, the whole range of possibilities for the human soul. In seeking the nature of soul, he sees it in its many forms and the fundamental tension this produces, between soul as a whole and soul as it manifests in any particular individual - the problem of "all soul" (245b). Phaedrus's soul could be readily identified with the "multicolored," as evidenced by the complex myths that Socrates must produce to hold his attention. ${ }^{39}$ But Phaedrus must also have something simple in him as a human being capable of speech and reasoning, by which the "one" being or form can be gathered together from its numerous instantiations (see $249 \mathrm{~b}-\mathrm{c}$ ). Hence the peculiarity that the multicolored soul does not receive multicolored speeches alone, but "panharmonic" speeches, that is, speeches that bring what is multiform into a single harmonious whole. ${ }^{40}$ As suggested in the previous chapter, the harmony of a speech must be understood in

\footnotetext{
${ }^{38}$ This difficult problem is taken up in the Parmenides (137c-d, 138e).

${ }^{39}$ The use of myth is related to the use of semblance in antilogic - these imprecise images are very suggestive to souls that do not demand utter precision. They allow agreement or deception in the same way long rhetorical speeches and unexplored opinions do.

${ }^{40}$ Burger 4.
} 
relation to the soul. The reemergence of harmony in this discussion of writing thus opens up a place for poetry in the nobler form of writing, as a way to bring souls that exist in a multitudinous and perhaps disorderly fashion into form - which would be most souls, if not all human ones, insofar as they are always in motion and struggle within themselves to establish the rule of the intellect.

Finally, the third revision is a slight but important one. Socrates now speaks of grasping "the race of speeches with art" as the end of this long study, rather than attaining "the grasp of the art [of rhetoric]" or becoming a "technikos of speeches" (272a, 273e). He thus reminds Phaedrus of the breadth of the art of speech, which encompasses not just the use of speeches for forensic, deliberative, or epideictic purposes, but every use of logos - as first suggested by his description of psychagogia as encompassing both public and private forms (261a-b). Socrates accordingly describes the aim of this art as twofold, "either to teach or to persuade," although the two seemed to converge, where persuasion depended on learning, and teaching was itself the highest form of persuasion, namely persuasion that follows from grasping the beings themselves (277c). But Socrates never eliminates the difference between teaching and persuasion, since doing so would deny the possibility of being persuaded of what is false and the possibility of error - without which there would be no learning and no meaning to "art." Socrates thus gives this less august persuasion its due, for in the face of human frailty and ignorance, it will remain the most prevalent and necessary use of speech. A beautiful or pithy exhortation holds an important place when complete certainty and truth are sought but cannot be secured for all time. Socrates' own frequent "mythologizing" about what is just, 
beautiful, or good, or "making speeches from any place," is a case in point, as indeed is his whole ironic manner.

Taking in hand the conditions of artfulness, Socrates now turns to the question of shameful and noble writing, which had been raised at the outset of the discussion of rhetoric: "And what about it being noble [kalon] or shameful with respect to both speaking and writing speeches, and at which time it might be said in justice to become a matter of reproach or not?" (277d, cf. 258d). Socrates expands the question of shameful writing to include both "speaking and writing" (277d, cf. 274b6-7). In fact, the general problem of shameful speech was suggested from the beginning of Socrates' first speech, when he covered his head in shame $(237 \mathrm{a}, 243 \mathrm{c}-\mathrm{d})$. What is shameful in writing will also shed light on what is shameful in speech simply. Socrates says that "at which time," the circumstances, will determine shamefulness in speaking and writing, that is, "the opportune moment," the kairos, mentioned in the discussion of rhetoric.

Socrates' final admonishment of Lysias shows that the principal mark of shameful writing is its inability to adapt itself to its audience and circumstances, or rather the writer's ignorance of his medium's limitations in this regard:

So either Lysias or someone else who has at some time written or will write in private or in public having laid down laws [nomoi], producing political writings, and believing [hëgoumenos] there is some great steadfastness and clarity in it, such is a reproach to the writer, whether someone says so or not; for to be ignorant, both awake and asleep, about what is just and unjust and bad and good cannot in truth escape being most reprehensible, not even should the entire crowd praise it. (277d-e)

The principal criticism that such writing lacks certainty and clarity had been developed earlier, when Socrates said was unable to enter into dialogue with its reader to clarify the meaning of its words. A psychological antecedent was provided in the palinode, where the soul of the lover had to look beyond the monuments he would make of his beloved in 
order to find the true nature of what he loved (250b, 250e-251a, 252a, 254a-d; cf. 235d-e, 236b). True clarity was found only in the superheavenly place and the plain of truth. In the discussion of rhetoric, there was a lack of clarity in the use of rhetorical techniques without knowledge of either the object or soul. In sum, the writer who ought to be reproached is one who has closed himself off to the true nature of things by believing that its clarity is possessed by the words themselves. ${ }^{41}$

The criticism of shameful writing therefore does not aim principally at what is said, but at the writer himself, at how he "believes" or "is led" (hēgoumenos). He is ignorant of how it is that living discourse leads him to the meaning of the external marks that he writes down. Indeed, the very belief that there is certainty in writing is something to which his soul has been led through uncertain discourse. Plato it seems has his own irony and sense of play. A reconsideration of Plato's use of the external mark "hēgeisthai" aptly illustrates how it is not the mark but the soul being led that bestows this apparent certainty. Here, Plato deliberately uses the verb hēgeisthai rather than other verbs of thinking, especially nomizein, which is related to law or custom (nomoi) in the sense of doing what is customary. Hēgeisthai is not so limited. In the palinode, "being led" was elaborated in the mythical leadership of the gods, especially the great leader or hēgemōn Zeus, in whose train lesser souls follow (246e). This divine leadership acts through the erōs that searches for god and longs to return to the eternal beings, the clarity of which is often mistakenly attributed to their instantiations on account of them being pleasing reminders (252e, cf. $250 \mathrm{~b}-\mathrm{e})$. One "believes" something to be the case because one is led to it, not in the first place by another human being, but by the already-present

${ }^{41}$ cf. Pl. Ep. $7.341 \mathrm{c}-\mathrm{d}$. 
desire that someone must address in order to persuade. ${ }^{42}$ On account of the meaning developed in the palinode, then, hëgeisthai signifies that the one who believes or thinks is already caught in the complex of desires that move soul and may confuse it, yet also direct it towards the perfection of the pure and simple beings. ${ }^{43}$ The man who believes there is clarity and certainty in the written word does not realize the complicity of his erōs in forming his opinion. That is to say, he does not recognize how that opinion was produced by and must be supported by what is for him uncertain and unclear. Insofar as this man does not see the activity of soul by which his words gain meaning, he is a nonlover whose soul and erōs remain hidden behind what is manifest to him, the "marks from without." ${ }^{, 44}$ Only when this secret erōs is itself revealed and made manifest to the non-lover will he be able to look beyond the words he has written or read to that which is truly clear and makes things clear. Lysias and the ignoble writer do not manifest the play that would evidence a higher understanding of speech in relation to the being itself. This appears to be why Socrates can so readily declare that this kind of writer is ignorant of justice and injustice, and goodness and badness.

In singling out amongst the possible objects of speaking and writing those that are of preeminent political significance - justice and injustice, goodness and badness Socrates reminds Phaedrus that the manner of speaking and writing encompasses the

\footnotetext{
${ }^{42}$ Compare how Socrates "is led" by Phaedrus's "shining head" and enthusiasm while reading Lysias" speech $(234 \mathrm{~d} 4)$.

${ }^{43}$ This is anticipated in the last sentence of Lysias' speech: "but if you miss [or: long for, pothein] something with respect to love, believing [hègoumenos] it has been left out, ask" (234c6). Also note how Lysias, perhaps inadvertently, links hegoumenos with the desire for secure and unending friendship and pleasure (232b).

${ }_{44}$ This also lends new significance to Socrates' question: "do you not believe that Eros is a son of Aphrodite and a god?" (242d9). In other words, is not the mere fact that you come to believe something to be true proof of some leading power that exists beyond mere words? Phaedrus could hardly think that persuasion or learning exist if it was true that $e r \bar{o} s$ and that which is outside of speech were nothing but madness.
} 
public as well as the private. The ignorant and ignoble writer does not see beyond the superficial manifestation of justice and goodness in the external markings of words, spoken or written. He may believe justice can only be something manifested in words. Socrates therefore reproaches him for submitting himself to the opinions and plaudits of the crowd, which by following he will "choose what is called blessed by the many" rather than cultivating that writing on the soul by which he can distinguish in those opinions what is true and what is false.

It is startling, though, that Socrates so explicitly confirms that his criticism of the clarity of writing extends to the law. In one respect, he gives credence to Phaedrus's irreverence for what is written as law, whether about the gods or otherwise, for the laws themselves are often in need of help though they appear to command by themselves the business of the city. They must rely on judges, litigators, threat of punishment, revision, persuasion, and so on to keep the citizens in harmony. The spell of the self-evidence of law is broken for the sake of the writing in the soul; "to think" in the sense of nomizein means to do customary things. Whether we are to suppose from this that Socrates opposed himself entirely to law insofar as it is but a "phantom" of what it images, i.e., justice, is another and difficult question, better addressed in the context of other dialogues. Still, his exoneration of writing as a reminder indicates that law should be understood more broadly to encompass both its written and unwritten forms. This depends upon a shared ethic and care for what was purposed by the law, rather than quibbling about the various meanings that can be attributed to its words. Souls that must be bound to one another on the seeming clarity of pledges have already lost sight of that highest perfection that truly erotic souls would never forsake (256d). The writing on the 
soul does not accord with those phantoms, but rather the highest nomos found in the Phaedrus: that mortal souls shall live according to their perception of true being $(248 \mathrm{c} 6$, c8).

On Plato's interpretation, Socrates' own decision not to write would seem to have been born out of these considerations. The written word is of limited utility in leading the soul. It fixes in place words whose meanings require constant review and revision in light of the opinions brought to bear on them, since different souls with different experiences and capacities will respond in different ways. Through such a medium, Socrates and his interlocutor could not engage in the dialogue and refutation of opinions that is necessary to light on real understanding and knowledge. The cultivation of the highest ends of the soul appears to have been the abiding concern of Socrates' rhetoric, while writing would have forgone the thinking by which the soul grasps its real objects, and simply descended into the common logos of the crowd.

\section{Platonic Rhetoric}

In dialectical fashion, the criticism of the writing characteristic of Lysias allows the unfolding of a noble form of writing. ${ }^{45}$ As with the ignoble writing, the form of speech and nature of soul that produce it are closely correlated - someone who believes that what is just, beautiful, or good exists or is clear only insofar as it is written down or spoken will never produce writings in the manner of Plato, which Socrates presently describes: "But the man who believes [hègoumenos] there is much play in the written word" believes that "there has never yet been written a speech, either in meter or prose,

\footnotetext{
${ }^{45}$ Note the antithetical construction men ... de at $277 \mathrm{~d} 9$ (men), the ignoble writing, and $277 \mathrm{e} 5$ (de), the noble writing.
} 
worthy of great seriousness" (277e). This man does not hold the opinion strictly opposite to Lysias', which would be that the written word is entirely opaque and in flux. Rather, writing is understood as "play," as if it were somehow childish and perhaps educational. Socrates emphasizes again that it is not frivolous play, but play in light of a great seriousness. This playfulness encompasses all forms of writing - not only are laws and political writings implicated, but also the great works of a Homer or Hesiod, a pious Pindar, and even the sacred written prophecies of the Pythia and Sibyl. ${ }^{46}$ Perhaps this is why Socrates has often cited the Delphic inscription, "know thyself," which turns one way from mere scribbles and the hope for an easy path, to the cultivation of that by which the logos is really grasped.

Continuing his description of the noble writer, Socrates also brings the criticism of writing to bear on oral speech. Socrates' analysis of rhetoric is not complete until he takes into account the form of speech that the use of writing tends to produce. He says that there has not been a speech worthy of great seriousness "spoken as the rhapsodes have spoken, persuading without examination and teaching, but that the best of them have proven to be in reality reminders for those who know" (277e-278a). Writing produces rhapsodic-like speeches - monologues that only speak and repeat themselves without examining or teaching its reader. Retrospectively, oral rhetoric that likewise does not teach will fail to attain the highest end of the art of speech, namely producing virtue (270b). Only teaching in this true sense of persuading a soul with respect to what really is would grasp the true virtue that is really "fitting" for a soul. The three speeches delivered in the first half of the Phaedrus are therefore guilty of this incapacity to really

\footnotetext{
${ }^{46}$ The priests who attended the Pythia at Delphi delivered oracles to the supplicant written in hexameter verse. The Sibyl's oracles were also written in hexameter (Parke 1988 6).
} 
teach or lead their audience, despite or perhaps because of their inspirational quality. ${ }^{47}$ Their rhapsodic manner could only dazzle with the momentary efflorescence of beauty fruit from the gardens of Adonis. Without examination and teaching, the audience could not come to knowledge. These significant limitations are not restricted, of course, to the speeches of rhapsodes, but to any logos that is a mere pronouncement or product of rote memorization that is not understood as merely a reminder but as something more. Such speech is an all too common part of rhetoric, which seizes on the opportunity to reduce the audience to a silent passivity, and so remains indifferent to the attainment of knowledge. ${ }^{48}$ These limitations would also apply to exhortations, such as Prodicus' Choice of Heracles, which Socrates thought fit to repeat, although it acquired a reputation for being pedantic. ${ }^{49}$ Socrates is himself no traditionalist who merely retells ancient stories of virtue, for his story-telling has a youthful or modern quality in that they redress the complacency and over-confidence of his interlocutors.

In light of this, will Socrates' own exhortations to philosophy and virtue succeed with Phaedrus? Socrates has refuted Phaedrus's opinions concerning the nature, ends, and means of rhetoric, but has Phaedrus himself engaged in this learning by examination or question and answer? The student it seems must also be active and not simply receive and then repeat what is told to him, but bring himself to examine and question those speeches. Otherwise, the student will never become independent of his teacher and be able to defend his own words. A number of Socrates' own students suffered this fate, losing sight of what they once saw with his aid and even turning away from philosophy

\footnotetext{
${ }^{47}$ Inspiration by Lysias' speech is mentioned at 234d, by Socrates' first speech at $241 \mathrm{e}, 265 \mathrm{a}$, and by Socrates' palinode at $257 \mathrm{c}, 263 \mathrm{~d}, 265 \mathrm{a}$.

${ }^{48}$ E.g., Grg. 449b-d, 457c-458c, 47le-472c, Ion 541 e-542a, Phd. 90d-91c, Prt. 328d-329b, 334d-338e, $R$. $344 d-e$.

${ }^{49}$ See Chapter I, note 4.
} 
without his guiding presence. ${ }^{50}$ So even Socrates, who examined his students' opinions through refutation and dialectic, could not transcend play and show with all clarity the true objects of seriousness, which remained dim and veiled by speech. His speech could only bring the soul to a clearing freed of false opinion, but the beings themselves could be glimpsed only if that soul had joined in the exercise seriously, as a matter of seeking something of value, and understood the grounds upon which their opinions had been refuted. Therefore only if the soul followed the logos as a guide, rather than seeing it as the answer or being itself, could it be led to the experiences portrayed in the palinode. Yet Phaedrus's vague understanding of logos, which has only been revealed over the course of the entire dialogue, that speech itself was something clear and capable by itself of providing for the desires of the soul, was a great obstruction for this real leading of the soul and dialogue, since it both hid the nature of those desires and refused the possibility that they could be explored through logos. Moreover, because of Phaedrus's understanding of the logos, Socrates was compelled to first address him on his own terms, in monologues of professed clarity that were filled with rhetorical flourishes.

In contrast to the understanding of logos held by Phaedrus and the ignoble writer, the noble writer will be "one who believes [hēgoumenos] that what is visible and perfect and worthy of seriousness is only in those things that are taught and said for the sake of learning about what is just, beautiful, and good, and really written in the soul" (278a). That to which one "is led" returns here to the highest objects of the palinode, the beings

\footnotetext{
${ }^{50}$ Socrates describes how this befell a number of his young associates, particularly Aristeides, who told Socrates that "I never learnt anything from you, as you yourself know, but I advanced, whenever I was with you," but "now that entire state has flown out" (Thg. 128c-130e). In the Symposium, the experiences of Apollodorus, Aristodemus, and Alcibiades are even more radical, where Apollodorus finds nothing worthwhile when separated from Socrates, while Alcibiades sees divine images in the older man yet flees from him in shame (172e-173a, 221d-222a).
} 
themselves, looking beyond the words themselves. In the palinode, it was said that only by "standing outside [ekistamenos] human seriousness" will someone be "perfected" by again glimpsing being (249c-d). True writing in the soul is being taught and learning, rather than merely oral discourse, as Phaedrus thought. The noble writer does not seek to produce Daedalean statues that walk and speak as they are commanded to, but men who are able to converse for the sake of searching for what is true; he wishes to produce souls that are themselves fertile and capable of passing on this "seed." These speeches, Socrates tells Phaedrus, "must be said as if they are legitimate sons," rather than just the "legitimate brothers" of the written word (278a). Socrates is now concerned with speeches as offspring of a man of particular character (cf. 276a).

Once this father of speeches has "discovered" the "one in himself," i.e., the writing in the soul or the living logos, he must see if "some offspring and brothers" of it will "grow in the souls of others according to its worth" (278a). The logos in him is brought to the test by its ability to take root in others. Only then will he see whether it has truly been planted with knowledge and has taken hold of what really is. True knowledge grasps the many ways that the beings themselves are manifested. This noble speech will therefore finally transcend the particularity of the audience, living in different souls at different times in different forms, while being akin as brothers and sons of the same pattern, in the same manner that every kind of human life shares in the same "form of the human" by virtue of having logismos (249a-c). The truly living and immortal logos will thus resemble the beings themselves, the manifestations of which are all necessarily different yet refer to and share in a single being that transcends each of them. On the basis of this, the father of speeches cannot be interpreted as someone to whom 
every soul that carries his "offspring" are beholden. ${ }^{51}$ Such a result, as likely as it may be, would in fact be the very opposite of what is intended here, for the logos is fertile only so far as it is the fruit of the soul's search and a living memory of the beings themselves - it is fertile so far as it gives rise to real thinking that has no need of recourse to its father (cf. 275e). ${ }^{52}$ The greatest father of speeches is he who is able to link his lineage to the beings that transcend any of his own speeches or writings. ${ }^{53}$

The logos that is planted in us and is written in the soul is that logos which is able to differentiate being, and is no longer a monologue, a set speech, a monument, but living and moving according to the hidden form of things that carries us between the one and many. The noble writer therefore does not implant this logos by way of such phantom speeches, but through the actual practice of psychagogia that involves, at its heart, the antilogic that refutes opinions and allows for a dialectical purification of thought and therewith the perception of being.

Socrates tells Phaedrus that such a writer, someone who believes all this with respect to the relation between logos and what is spoken of, is one that "you and I should pray that we might become" $(278 \mathrm{~b})$. He will see beyond the words to the beings themselves, and become capable, in his writing, of leading souls not to beautifying image of those beings, but to the manner by which they may search for themselves and look upon what really is. He will show his students and readers how it is that his words are only play in light of the far greater work of philosophy. There seems to be little question that the noble writer intended here is none other than the man who playfully wrote this critique of writing. Plato, through his own irony, tells his readers that he is the divine

${ }^{51}$ Contra Derrida 117: the use of logos is an "act of both domination and decision."

${ }^{52}$ See also Pl. Ep. 7.340c.

${ }^{53} \mathrm{Pl}$. Menexenus $247 \mathrm{a}-\mathrm{c}$. 
answer to Socrates' prayer and attained what Socrates never could. Since this conclusion, that Plato intended by Socrates' prayer nothing more than an obvious and vain self-flattery, imputes to Plato such a great conceit, some reconsideration is warranted. What is the problem that Socrates advances here that would make him pray and hope for divine assistance?

The man prayed for, the paradigm for Socrates and Phaedrus, is first and foremost someone who believes that there is no serious and clear writing or speaking without examination and teaching. He is not strictly a writer or rhetorician. What Socrates outlines is an $\bar{t}$ thos, a manner of living or character, rather than a particular profession or activity, which may be characterized in the terms used to describe the lover: openness to being. This man does not seek or find perfection in logos, but only in what it enables him to perceive. He is always able to keep before him the nature of speeches as reminders. Although such a man does not find justice, beauty, and good in speeches, neither does he lose sight of these things, for speeches must be used to teach and help him examine these things. His knowing will not consist in the memorization of texts or speeches, which he will only do so far as they assist in the serious work of learning and clearing the way so that the living logos may grow. This is an êthos of continual exercise in openness, which must be done in the manner Socrates has frequently repeated - dialectical exercise in the refutation of the opinions and speeches that are continually presented to him by himself and others. Finally, his manner of being and ability to see the logos as a reminder is only maintained in relation to others, since the legitimacy of his "son," his logos, is only discovered in conversation with others and proven by his persuasion of them, having understood their natures and the logoi for which they are suited. His $\bar{e}$ thos is 
consequently nothing less than the discovery and production of justice, beauty, and good in himself and others, as the crowning achievement of rhetoric. His logos is reproduced, not through a feast-day monument, but through instilling a like êthos ("other logoi in other characters [êthoi] " [272a2]) of perpetual initiation and practice. ${ }^{54}$ All this is a prayer, for such a man would never succumb to those natural desires that would close him to the search and lead him to believe he had found truth and perfection in a speech or object he had grown fond of; this is a life of self-refutation that could never take its particular works seriously. If Plato did not intend to merely flatter himself, but to embody this serious purpose, his writings must somehow admit of this playful selfrefutation and be capable of cultivating thinking in his readers. ${ }^{55}$

Accordingly, Socrates says that "we have now played in a measured way with respect to the business of speeches" (278b). Socrates rightly places the whole discussion of logos in the realm of play, and so includes himself and Phaedrus in the êthos of the noble writer. They have found the logos as the way for purifying the view of being. This will be the heart of Socrates' message concerning how one writes in a noble way: "tell this to Lysias and anyone else who puts together speeches, as well as to Homer and anyone else again who composes poems that are bare or in song, and third to Solon and whoever in political speeches writes compositions he calls laws" (278c). As noted earlier, the scope of Socrates' analysis and criticism of writing is incredibly broad, encompassing rhetoricians, poets, and legislators. Indeed, the message is addressed to Lysias as well as any writer, past or present, and so goes far beyond the scope of Phaedrus's and Socrates' personal relations. It is unclear whether Socrates believes that

\footnotetext{
${ }^{54}$ Ep. 7.340 c.

55 Friedländer writes that "irony guards the Platonic secret" (1.153).
} 
this universal message, imparted only to Phaedrus, can find a similarly universal audience.

Socrates' final message is a concise set of three conclusions. First, the writer is to compose knowing that he holds the truth. Second, since he is able to come to its assistance and elaborate on what is written, he can "go into a refutation [elenchos] concerning what he wrote" $(278 \mathrm{c})$. Third, when the writer speaks, he is able to show that his writings "are wretched." The first point in the message has been an abiding concern for the entire discussion of rhetoric, since Phaedrus opined that rhetoric did not require knowledge (260a). This of course does not mean that a composition written by a knowledgeable man is simply true, as has been shown in the discussion of writing. In fact, the other two points of this message, and the proof of the writer's understanding of his medium, depend on him showing the opposite.

The second point, that the writer is able "to go into a refutation concerning what he wrote," is derived from the ability of someone who is knowledgeable to assist his written speech (see 278a). More than just being able to elaborate on its arguments, the writer is said to refute his writings and himself. This would evidence that he possessed something of greater worth than his writing. It also means that the writer must somehow be present and always accompany his composition; as Socrates said before they examined Lysias' speech, "Lysias is present," though Lysias' speech proved unable to defend itself adequately let alone refute itself $(228 \mathrm{e} 1) .{ }^{56}$ Unless a particular way of writing could be found, the need for the author to be present would defeat the purpose of writing

\footnotetext{
${ }^{56}$ In another example of using a written composition, Zeno could only elaborate on and defend it when he himself was reading it to an audience (Prm. 127c ff.). On other hand, Zeno's speech was intended to come to the aid of Parmenides' own poem and words, which it did by beginning from the opposite position, i.e., as a refutation. Zeno should not therefore be considered innocent of the possibility of his speech being "stolen" (Ibid., 128a-e).
} 
altogether. Socrates hints that the author's presence has something to do with the ability to refute itself. Such writing would contain contradictions - the very contradictions or opposites indicative of antilogic and persuasion. The knowledgeable writer, knowing that any single speech could not really manifest what he knows, would leave reminders of his intent in the form of contradictions and paradoxes that point beyond themselves. Many techniques that could achieve this purpose were mentioned in the discussion of rhetoric, not least of all Evenus' covert techniques that were said to be "aids to memory" (267a). Writing of this kind thus aims to produce aporia in the soul of the audience, which compels the soul to seek a resolution of those contradictions under a higher understanding of what is written in the text (see 255d3). ${ }^{57}$ The truth itself lies hidden behind the outward appearance or superficial teaching of the text, and in its arrangement or form. A writer therefore comes to the aid of his writings by writing speeches that will lead its readers not to a single dogma, a repetitious speech, but to a desire to understand. In order to assist his writing, the noble writer must cultivate a kindred $\bar{e}$ thos in the reader. The reader enters into a kind of dialogue with the text, thinking through its contradictions, and thereby develops his own reasoning and "writing on the soul." At the highest level, writer and reader will attain the homonoia, "being of the same mind," that Socrates earlier attributed to philosophic lovers (256bl). The author's "seed" becomes immortal because it is able to reproduce the tensions in the soul which arouse logismos and by which it perceives the beings themselves.

The greatest seeds or writings will be those that are able to touch on and reproduce this fundamental structure of tension, which the palinode showed to inhere in

\footnotetext{
57 "It is in these such cases [of contradiction] that the soul, summoning reasoning [logismos] and the intellect, attempts to see whether each of the things reported to it is one or two" $(R .523 \mathrm{c}-\mathrm{e})$.
} 
the beings themselves, insofar as they exist in many instances yet are at the same time one form, pure and unmoving. Beauty itself is paradigmatic for the tension experienced by the soul, for its superficial attractiveness conceals its true nature, and casts those who behold it back on themselves in search of that nature. The natural desire to take hold of, make one's own, and never lose what pleases can become a powerful instrument for persuasion. That the being of the most manifest of beings is hidden yet inspires those who behold it is perhaps the greatest seed of all.

The third point in Socrates' message to Lysias follows closely from the first two. The author will be able "to prove" that his "writings are wretched" (278c). The refutation of his own writings demonstrates their insufficient and pale imitation of the truth. His audience is thus led to suppose that he does in fact hold something of greater value and worthy of seriousness, and so to inquire for themselves as to what is hidden behind the self-contradiction of the writing. One example of how an enlivening contradiction can be implanted in a text is found right here: how does a man help something by demonstrating that it is wretched and refuting it? The readers who attempt to solve such riddles do not become sycophants that merely repeat the author's words, but seek to become capable in their own right.

Socrates crowns the three points of this message with the title of the writer who is able to embody this $\bar{e} t h o s$. He will not derive his title from "these things" - his speeches and writings - but from "those things he is serious about" $(278 \mathrm{c}-\mathrm{d})$. The title assigned to this writer, Socrates tells Phaedrus, cannot be "a wise man," for that belongs only to the gods (278d). Rather, a "more fitting" or "harmonious" title is philosopher or lover of wisdom, someone inspired by the knowledge that he lacks wisdom and must seek it. 
Only now does philosophy reemerge to fulfill Socrates' wish in the discussion of the art of rhetoric, that his arguments "persuade Phaedrus ... that unless he should philosophize sufficiently, he will never be sufficient in speaking about anything" (261a). This late emergence of philosophy casts doubt on whether any of the particular moments of the preceding discussion of the art of rhetoric suitably encapsulate philosophy. Perhaps even the art of dialectic, although necessary for "thinking and speaking," does not adequately account for this way of life or êthos, given that the real attainment and artful perfection of dialectic depended on the complete knowledge of the whole - knowledge that would mean one ceased to be a philosopher and had become a god. If, then, it is questionable whether the philosopher is a dialectician in the strict sense, Socrates leaves the philosophic life as a question. Is it possible for a human being to obtain the wisdom sought by the philosopher? Without the possibility of true wisdom, as found in the complete dialectician, there would not be either art or the knowledge it depends on, but only eristic and artless stumbling to greater or lesser degrees of efficacy. Plato therefore brings the discussion of rhetoric to a close not with a solution to the problem of persuasion, but with one final problem concerning whether the art of speaking will ever be adequately grasped. ${ }^{58}$

Plato brings into sight the most serious of things - the living logos and the life of philosophy that seeks the nature of the whole - at the same moment that he criticizes writing and therefore casts derision on "or shows to be wretched" everything that has come before in the Phaedrus. The emergence of philosophy saves the Phaedrus from the

\footnotetext{
${ }^{58}$ Klein argues that the Phaedrus does not in fact provide a particularly robust account of good writing; in elenchic fashion, it is primarily concerned with learning what is bad speaking and writing. He asks whether "the answer to the question as to what constitutes good and proper writing has been deliberately and playfully withheld?" (16).
} 
criticism of writing and the risk that it is trivial play that reduces all speech to meaningless contradiction and opacity. The successive refutations that Plato has written over the course of the Phaedrus, including the refutation of Lysias' speech, the "merely human," Phaedrus's opinions, the ignoble rhetoric, and finally writing itself, collectively serve to indicate the presence of a higher mind and understanding of the nature of things - a higher view and necessity that guides all these refutations. The very form of Plato's writing is therefore an imitation of the philosophic life that, beginning with what is found in common opinion, engages in a truly enlivening and ennobling search for that which is only dimly perceived in those opinions. In a sense, Plato has written a fitting monument or reminder of what is truly divine.

Those writers who do not possess something "of greater value" than what they write will not be considered philosophers, but only "poets" or "speech-writers" or "lawwriters." Such men would endlessly turn their speeches up and down as they tried to compose something of value (278d-e). This does not mean such writings could not also be produced by philosophers, although the works themselves would not be philosophic. But if a writer wanted to compose in a manner that would evidence the philosophic life, he would have to do so in the manner just outlined in Socrates' message to Lysias. That is, they would have to show that their writings are "wretched" and can be refuted, betraying something "of greater value" in-between the words themselves.

In the case of Plato's rhetoric, his writings both display and embody the Socratic life, the search for wisdom through conversation, and present that life as the paradigmatic human life. In this sense, the philosophic life is the "reminding from within," inside the “reminding from without" constituted by Plato's words. Plato's writing must imitate 
Socrates' rhetoric if it is to truly engage readers in the philosophic experience and persuade them of the necessity of philosophy. The means by which Plato does this can be briefly summarized. Since Plato himself points out writing's defects - endless repetition, saying the same thing to every reader, and needing assistance - it is reasonable to assume that he thought he had found a way to counteract them or use writing's properties to rhetorical advantage. In the first place, Plato's dialogues endlessly repeat themselves so that future generations of students may carefully reread them in search of the one form that manifests itself in Socratic play. ${ }^{59}$ Phaedrus and Socrates demonstrated this by re-reading Lysias' speech. ${ }^{60}$ Socrates' guiding presence is to some extent replaced, as noted earlier, by the text itself and the need for the reader to account for its words and form. ${ }^{61}$ Towards this end, logographic necessity is a useful heuristic principle. Second, it is true that Plato's writings speak to everyone and do not adapt themselves to the particular reader, at least to the extent that the words can be read by anyone, but since they must be interpreted there is already a discrimination of audiences. Plato also wrote dialogues, meaning that they are conversations carried on with reference to the specific questions and answers of the interlocutors. Since the dialogues are conducted ad hominem, they are already limited with reference to the true nature of the whole and do not speak as if they were utterly clear; they can only embody that part of the whole which could be seen from the particular context of the setting, topic, and dramatis personae. Phaedrus's character, for example, has been shown to exert great

\footnotetext{
${ }^{59}$ See Ep. $2.314 \mathrm{a}, 6.323 \mathrm{c}-\mathrm{d}$. Plato notes that other students of Socrates had already begun memorizing and writing down his conversations for study (Tht. 142d-143a).

${ }^{60}$ Plato thus goes beyond Alcidamas' criticism that writing is unable to adapt to the momentary needs of action and extemporaneous speech (Alcid. Soph. 9-10)

${ }^{61}$ In the Sixth Letter, Plato suggests that the static nature of writing is useful, especially if it counteracts natural habits (Ep. 6.323c-d).
} 
influence on what Socrates says in the Phaedrus - which is not to say that a glimpse of what really is is not attained, but only that this glimpse is only a glimpse and never consists of a plain monologue or disclosure. There is no universal speech like an oracular or rhapsodic pronouncement because persuasion must account for the differences between souls. ${ }^{62}$

Third, the apparent defenselessness of a writing is counteracted by the dialogue form; the meaning of the work is not expressed simply, but through the peculiar features of a dialogue, just mentioned, in addition to the arguments of the interlocutors. A reader must account for both action and speech. There is an erotic or psychological basis for the logos, as indicated throughout the Phaedrus, that must also be interpreted in order to see the meaning of a logos not as it is manifested in words but in light of its relation to what really is. For example, the meaning of Socrates' first speech, although it expresses itself clearly, is lost when taken out of its dramatic context and apart from its inspired proem and prologue. The defenselessness of a writing is also counteracted by the presence of contradictions that naturally arise from Socrates' refutative form of dialogue. ${ }^{63}$ The reader himself comes to the aid of the text in an effort to understand it.

The possibility of a noble writing, whatever its form, ${ }^{64}$ does not address why it is that Plato would pursue writing at all. Even if its limitations can be overcome, what advantages over oral discourse inspire its use? Plato's decision to write cannot therefore be reduced to the political act of memorializing Socrates, without also being a

\footnotetext{
${ }^{62}$ White 256, contra Derrida 115.

${ }^{63}$ Compare Zeno's dialectical refutation of the hypothesis that the many are, i.e., the hypothesis contrary to his beloved Parmenides'. The latter's poetic declaration requires argumentative support, of which a refutation of the contrary is the strongest.

${ }^{64}$ While Plato has addressed the defects of writing through the dialogue form, it does not follow that this is the only manner of noble writing. The writer must know what it is he writes on, be able to defend his writing when called on to do so by refuting what is explicitly said, and show that the writing itself is wretched. It is fathomable that a treatise may also perform these functions.
} 
supplement to or even correction of that life. ${ }^{65}$ There is no explicit mention in the Phaedrus of the danger posed to the philosopher by publicly expressing his thoughts, so it cannot be said that the difference between Socrates and Plato lies in the desire to avoid persecution. Nor can it be seriously maintained that Socrates was capable of writing at the level of Plato had he only wanted to, for his entire life was a testament to the fact that he did not see a manner of doing so that was worthy of philosophy. ${ }^{66}$ Plato of course does not explain his intention directly, and so the extent that his purpose in writing is revealed in the Phaedrus can only be ascertained by reconsidering the dialectic between the oral and written word found in Socrates' dialogue with Phaedrus.

Thamos's judgment on writing opened this dialogue between the oral and the written, Socrates and Plato, on the grounds of memory. Socrates' identification of three defects of writing showed how writing fails to engage in the searching dialogue necessary for learning and teaching, which is the highest form of recollection. The potential advantage of writing became clearer when the "writing on the soul" was invoked as an analogy for true knowledge that transcends any particular speech. This moment sheds light on the difference between Socrates and Plato, since the writing on the soul, or rather the knowledge in the soul, transcends speech, either written or oral. Socrates' criticism of writing, and his refusal to write, is seriously qualified by this revelation of the transcendent nature of the "living logos." Moreover, oral discourse more often than not fails to ascend to such heights. The inert and repetitious written word may be only a phantom of the living logos, but it nonetheless gives the appearance of possessing properties of true knowledge and being that oral discourse is incapable of, namely an

\footnotetext{
${ }^{65}$ Plato's depiction of Socrates' life is frequently understood as an unproblematic celebration. See, e.g., Nicholson 86-7.

${ }^{66}$ E.g., Pl. Phd. 60c-61c. See Strauss 245-6.
} 
unchanging universality. ${ }^{67}$ Socrates' admission that writing too can be pedagogical, so far as it counteracts its limitations, is not balanced by the possibility of oral discourse that is unchanging and universal. To be sure, the knowledgeable writer must be capable of expressing himself and assisting his writing orally, but those spoken words are more limited by their own mortality, in the sense that they do not possess the fixity of what they are meant to signify, as well as the mortality of those who hear and speak them. The immortal living logos cannot be adequately represented in the spoken words of a single mortal man; its universality is only manifested as a pattern that is capable of being replanted and cultivated in others across space and time. While Socrates was able to adapt his speech to the particular soul before him, he was unable or unwilling to address a crowd, let alone speak after his death - and granting that he implanted his logos in his followers, it inevitably failed to live as does the truly living logos insofar as it was subject to the vicissitudes of human memory and intellectual capacity. Socrates would or could not persuade the dèmos as a whole to cherish his logos and make monuments for the sake of remembering it.

Did Socrates' refusal to write originate from his indifference to that lower form of immortality, pursued by the legislators, that consists of lasting glory and honor through the memory of others (258b-c)? Jaeger suggests that Socrates did not write because his service was to his city, Athens, not some universal "humanity." ${ }^{18}$ Perhaps Plato believed there to be some more universal in the Socratic experience that required an accordingly public and popular medium. Outside the city walls in the Phaedrus, the "spiritedness" or

\footnotetext{
${ }^{67}$ Since "reminding" is the only use of writing explicitly mentioned by Plato, this must be what al-Fārābī means by his opaque suggestion that the Phaedrus shows "what it is that writing achieves and the extent to which conversation fails in this respect" (al-Fārābī 2.6.28).

${ }^{68}$ Jaeger 2.74 .
} 
thumos characteristic of honor and political life is never explicitly mentioned, and only appears through the love of honor that keeps the soul beholden to the opinions of the city. Did Socrates' philosophic erōs so control the lower part of the soul that is concerned with the opinion of others, the thumos characteristic of the white horse, as to eliminate any desire for glory, as Leo Strauss suggests? ${ }^{69}$ Was Socrates concerned that any monument made of him and his logos would only be a monument, and therefore an obstruction to following the true logos towards knowledge of what is eternal? Any admission that he was in fact interested in such immortality would reduce Socrates to the sort of non-lover that politicians pretend to be (257d-258d). As Strauss points out, Plato certainly would not have continued to write had he recognized that this form of immortality was in fact lower in every respect than the private striving of an erotic soul. ${ }^{70}$ And Socrates himself, at the end of his life, will express concern that "[his] logos may die." "71 Plato must have believed that there was something valuable that could be attained through that monumental glory - which does not imply that he desired glory as the highest end, only that he saw a use for it. ${ }^{72}$ But if there was a use for the immortality that writing can bestow, one that did not compromise the soul's erotic openness, why did Socrates not pursue it? Socrates was not ignorant of the rhetorical opportunity afforded by reputation. ${ }^{73}$ Socrates' refusal to write can therefore only reflect a failure on his part to see the higher powers of writing to keep alive the "living logos"; Plato attained a deeper understanding of the whole range of erotic experience. Plato shows the ground of Socrates' speeches and experiences in a way Socrates never could. Plato's rehabilitation

\footnotetext{
${ }^{69}$ Strauss 246-7.

${ }^{70}$ Ibid., 246.

${ }^{71}$ Phd. 89b-c.

${ }^{72}$ E.g., Ep. $2.311 \mathrm{~b}-\mathrm{c}$.

${ }^{73}$ E.g., Pl. Ap. 34e-35b, R. 336c.
} 
of writing means Socrates failed to understand how it is that the logos becomes immortal, which means he failed to understand both the nature of the logos, the living logos, and the human soul that dwells with it. To use the analogy of the two farmers, the one who plants for feast days and the other for real growth, Socrates only seems to be capable of the latter, and even then only to a limited extent. His rhetoric would cease to be erotic in the sense of searching if he gratified his interlocutors with the beautiful speeches of a feast day - he would be like a Gorgias or Thrasymachus and make cicadas of his audience. Plato on the other hand is freed from the strictly ad hominem constraint of Socratic rhetoric by virtue of writing, and may combine the talents of both farmers. Since he addresses many people at once, he can address both a range of souls as well as the range within the single soul, at one time amusing them with Lysias' speech before dispelling it, then at another giving a dazzling account of the whole in the palinode, which he then offsets with a rather plain discussion of the nature of rhetoric. Not entirely dissimilar to Teisias' probability, Platonic rhetoric addresses the multitude of soul types in a harmonious way that Socrates could not, as if Plato had perfected the art of dialectic so that he could collect and divide every kind of speech and soul.

Writing allows Plato to give the appearance that "all soul" finds its mirror in him. He is "seeming-wise" (doxosophos), but knowingly and therefore playfully so. ${ }^{74}$ Plato's playfulness, especially evident in the Phaedrus, embodies beauty as that which is most manifest and superficial while concealing the truth. As Anne Lebeck says, "in language and form the dialogue so perfectly is what it discusses, exemplifies what it advocates,

\footnotetext{
${ }^{74}$ In the Phaedrus, Plato omits the politic concern of self-preservation for careful writing that he expresses in the Seventh Letter (Ep. 7.341e).
} 
awakens the reactions which it describes." 75 Socrates' irony and elenchos can only imply a greater whole; he cannot gratify his audience's desire for unity and a complete vision of that whole, a desire he himself identified in the palinode. Dionysius Halicarnassus suggested that Plato took over the "grand and simple" style of Thrasymachus. ${ }^{76}$ The Arabic philosopher al-Fārābī similarly claimed that Plato combined "the method of Socrates" and "the method of Thrasymachus." This is to say that Plato is able to direct the passions of his audience (which he did to the greatest extent in the palinode, in order to gratify the soul's longing for the whole), yet also able to attend to the true art of planting seeds found in Socrates' elenchic rhetoric, so that his readers would be persuaded that something of greater value did in fact lie behind the surface of his poetry. Plato preserves Socrates' refutation of the idols of common opinion, and even accentuates it by setting opinion as such against resplendent images of transcendent and eternal beings. Plato "rolls out" the Socratic experience "everywhere to those who give ear." If, then, Socrates lacked thumos, it cannot be that he did not recognize how to win honor and lovers by gratifying their desires and flattering them, for he was to some extent successful with honor-lovers such as Alcibiades and Charmides. Instead, a lack of thumos can only be understood in relation to the demmos - he won the honor of thumotic men by refuting their own love of the dēmos. ${ }^{78}$ Insofar as Socrates refused to write, he failed to demonstrate that he had laid hold of the logos and understanding of soul sufficiently enough to persuade the demos, let alone every human being. He insisted that

\footnotetext{
${ }^{75}$ Lebeck 267, emphasis in original. See also Santas 108.

${ }^{76}$ D. H. Demosthenes 3.

${ }^{77} \mathrm{Al}$-Fārābī 2.10.36. This is ultimately the inspiration for Strauss's approach to "the problem of Socrates," i.e., the historical Socrates versus the Platonic Socrates, and is therefore a significant influence on his approach to the question of why Plato wrote and Socrates did not (Strauss 246-7).

${ }^{78}$ E.g., Smp. 216 a.
} 
he was ignorant, and that this was the wellspring of philosophy. The irony of Socrates' wisdom is that it could not be made manifest and clear to the extent his interlocutors desired. Only through the intervention of Plato could a "terrible longing" be generated for what is most desirable for every soul. Plato is able to keep open a view towards eternity in a way Socrates never could.

This grand vision of Plato's supplement and correction of Socrates cannot be definitively proven. In the end, it is Socrates himself who "mythologizes" and delivers the monologues of the Phaedrus and the other dialogues, although one wonders whether the "nymphs of the place" that inspire him to speak with art are nothing more than Plato himself, and that Plato really did place Socrates outside of himself in order to give an account of his rhetoric. ${ }^{79}$ The beauty of the Platonic dialogue is largely transmitted through the mouth of Socrates, and the extent to which Socrates' conversations reached the splendid heights portrayed in Plato is an enduring problem, for the two cannot be decisively distinguished. ${ }^{80}$ Neither do the limitations Plato saw in Socrates' rhetoric indicate that he could have removed Socrates from his dialogues or his writing as a whole; his whole presentation of philosophy is derived from his interpretation of the Socratic experience and the soul of "the most just man of those then living." refutation of Socrates' oral practice is proof that he could stand independent of Socrates, the father of his logos, yet also demonstrates that Socrates truly grasped the immortal living logos because it reproduced itself in his student's independent thought. Even as Socrates fades from dramatic prominence in what are called the late dialogues, his

\footnotetext{
${ }^{79}$ See Phd. $61 \mathrm{~b}$.

${ }^{80}$ Diogenes Laertius recounts the story that Plato had written the Lysis while Socrates was still alive, which upon reading the latter exclaimed, "By Heracles, this young man utters so many falsehoods about me!" (D. L. 3.35).

${ }^{81}$ Ep. $7.324 \mathrm{e}$.
} 
presence is felt in the playful form of Plato's writing. There was always "the Socrates in him." 82

\section{Return to the City}

Socrates has given Phaedrus a message in preparation for their return to the city. Phaedrus will disseminate Socrates' teaching on writing to Lysias and perhaps, through the rhetorician, affect a new understanding of the logos in the city at large. But what sort of a messenger will Phaedrus be? Although he is an eager solicitor and, at times, dispenser of speeches, this eagerness is born from a trivial and hedonistic approach to speeches. And what will he remember from this conversation? For the same reason he is a lover of speeches and an eager messenger he is also unsuitable - his desire to be gratified by speeches has made him reliant on books and weakened his memory, and for the most part has only followed Socrates' lead in the conversation $(227 \mathrm{e} 1-228 \mathrm{a} 3,228 \mathrm{a}$ b6, 228d1-5, 273a3-5, 277b4). No doubt his recollection of the conversation for Lysias will not be verbatim, and many of the particular arguments will be lost, but the outstanding images of the winged chariot of the soul, the cicadas' song, and the Egyptian tale will be sufficiently vivid to hold a place in his mind. Perhaps even the conclusions concerning dialectic and rhetoric will be recalled, given that Socrates recapitulated them three times (271a-b, 271d-272b, 273d-274a, 277b-c). At the least, the general impressions produced in him will remain - such as Socrates' rhetorical victory over Lysias, the rehabilitation of erōs, the need for knowledge in rhetoric, and the criticism of writing.

\footnotetext{
${ }^{82}$ Friedländer 1.144.
} 
If nothing else, Phaedrus will be an eager gossip and teller of his ecstatic experiences with Socrates, a rhapsode in his train. It is precisely his superficiality that recommends him. As is befitting his name and the theme of the entire dialogue, the man "Phaidros" is himself a "showing forth." If his physical beauty and superficial love of speech could be harnessed to "something of greater value" to betray some wisdom beneath the "silver filigree" as one commentator has called it, Socrates would find a very useful friend indeed. ${ }^{83}$ Socrates, for the purpose of "plating his seed" in others (which would not be an idle vanity but indeed a great philanthropy), ${ }^{84}$ could multiply the effect of his rhetoric by winning over the beautiful favorite of the speech-writers. A literary dilettante or "impresario," as Ferrari says, Phaedrus is the most adulatory audience, consumer, and disseminator of the speech-writers and rhetoricians. ${ }^{85}$ Indeed, Phaedrus's multicolored soul is a helpful reflection of the panoply of soul types to be found in a broader audience, for which Socrates has produced speeches that are fittingly variegated yet harmonic. But if that is all Socrates has done, he would be guilty of producing "feast day" rhetoric and trifling pleasures. Instead, the harmony of Socrates' rhetoric is found in how he supplements the poetry and beautiful images, helping them take root in deeper soil, by discussing them with Phaedrus and showing how it is that they have worked on his soul. These two moments of myth and logos are sustained in a dialectical and fertile tension, the former providing an inspiring whole and the latter demanding a persuasive

\footnotetext{
${ }^{83}$ Rosen 1990 188, 202-3.

${ }^{84}$ In the Seventh Letter, Plato writes: "If it appeared possible for [these things] to be written or spoken sufficiently for the many, what nobler thing could I have done in my life than this, to write what would be of great benefit for humanity and bring the nature [of these things] into light for all? But if I undertook the endeavor of expressing this to human beings it would not be good for them, except for some few who are able to discover the truth for themselves through little instruction, and the others would be filled with an incorrect high-mindedness that is in no way harmonious, and still others [would be filled] with a lofty and empty expectation, as if they had learned great things" (34ld-342a).

${ }^{85}$ Ferrari 19874.
} 
differentiation and analysis of its parts. Lysias and the speech-writers themselves would be compelled to compete with Socrates and adapt to the rhetorical countercharms that have been implanted in Phaedrus. Through Phaedrus, Socrates could reach Lysias, and if he could turn him to philosophy, like his brother, Socrates could reach the city as a whole by inspiring a noble rhetoric. Nevertheless, while Socrates' need for a messenger reflects the natural spreading of his seed, it also other reflects the limitations of his strictly oral practice. Phaedrus, after all, will soon be exiled for defaming the Eleusinian mysteries. Will he recall the real reasons for Socrates' use of their language and symbols? Far more effective would be a written account that would remedy the limitations of Phaedrus's memory and "remind" whomever came across it.

In order to provide a contrast to Phaedrus's limitations and Lysias' ignoble writing, Plato does not point directly to himself, but to Isocrates, another associate of Socrates who chose to write rather than strictly follow his teacher's oral practice. Phaedrus tells Socrates that they should not pass over his companion, "the noble [or: beautiful, kalos] Isocrates" (278e). Phaedrus seems to think of Isocrates because of his resemblance to Lysias as a speech-writer, a man who also seems to be an antipode of Socrates in this regard. ${ }^{86}$ Phaedrus does not believe the message for Isocrates will be the same, and consequently does not see where Isocrates fits in Socrates' account of writing. "What will we say he is?" Phaedrus asks. That is, is Isocrates a mere writer of political speeches, or is he a philosopher? ${ }^{87}$ Apparently, Isocrates does not write in the manner of

\footnotetext{
${ }^{86}$ Although Isocrates wrote speeches in forensic, deliberative, and epideictic style, he never delivered them in person, and instead circulated the speeches as pamphlets (in his own words, he "kept quiet" all his life [Isoc. Letters 6.2]). He claimed, at the end of his life, that he was driven to a primarily literary career on account of a weak voice and fear of public speaking (Isoc. Panathenaicus [Isoc. 12] 9-10; cf. Alcid. Soph. 15). Still, he could not be said to be entirely literary in his use of rhetoric, given that he founded his own school of rhetoric and therefore taught (D. H. Isocrates 1; Pseudo-Plutarch, Lives of Ten Orators 4).

${ }^{87}$ Cf. Euthyd. 304d-306c.
} 
Lysias or for the same purpose, yet neither does he evidence the attributes and ethos of the knowledgeable writer - playfulness for the sake of teaching and the ability to refute what he has written. Are his writings philosophic?

Socrates' and Plato's assessment of Isocrates' work bears some scrutiny, since it is not merely a matter of historical trivia, but sheds further light on Plato's selfunderstanding of his writing. ${ }^{88}$ So far, the only comparison has been to Lysias, Teisias, and other rhetoricians whose principal purpose was simply persuasion. Isocrates, as an associate of Socrates, and also one who exhorts his audience to "philosophy," seems closer to Plato. ${ }^{89}$ But did Plato regard him as a peer, or find some limitations in this admittedly nobler rhetoric? Any answer to these questions must be speculative and provisional, given the slim evidence in the Phaedrus.

Although Isocrates is still young, Socrates wishes "to prophesize" about his prospects (278e-279a). Socrates again plays the seer, but it is not in a simply ecstatic manner, for it is his knowledge of the nature of Isocrates' soul that allows him to see what might unfold in the future: "he seems to me to be better by an order of magnitude with respect to his nature than the speeches associated with Lysias, and to have a character [ēthos] mixed even more nobly [lit. in a more well-born way, gennikōterōi]" (279a). Isocrates therefore possesses one of the three elements of a successful rhetorician, a well-suited nature, and since he has already been writing at this point, he has begun to practice as well (279a6). It remains to be seen whether he possesses the

\footnotetext{
${ }^{88}$ By all accounts, Plato would have written and published the Phaedrus well into Isocrates' career, since Plato wrote from 400 at the earliest to his death in 347, and the older Isocrates from 390 - c. 342 (the plausible date of the Panathenaicus). Plato therefore would have been familiar with the rhetorician's works that are most relevant here, including his Against the Sophists, Areopagiticus, Encomium of Helen, Panegyricus, and possibly the late Antidosis.

${ }^{89}$ Isoc. Against the Sophists (Isoc. 13) 1, 3, 7.
} 
third criterion of knowledge and if it is evident in his works (cf. 269d). Socrates implies that he does by subtly changing Isocrates' epithet of "noble," from Phaedrus's kalos to gennikos: the latter is used to refer to a natural capacity or descent, a lineage, rather than a fine or noble bearing or appearance. Socrates, by calling Isocrates gennikos rather than kalos, recalls his earlier use of the related gennadas, also "noble" or "well-bred," to describe the noble and gentle souls that would be shocked by Lysias' account of erōs, as if they were listening to people who were raised by sailors and never saw the erōs of "a free man" (243c). Isocrates, being so well-bred, would also be aware of this higher erōs, and would not pander to the desires and opinions of the many.

This grasp of a higher erōs is borne out in the remainder of Socrates' prophecy, which says that when Isocrates grows older,

with respect to the very speeches he now works on, he would differ [from Lysias and others] more than [do men differ from] boys in the arranging of speeches, and still more, if these things are not sufficient for him, some more divine impulse [hormē] might lead [him] to something greater, for there is some philosophy in the mind of the man. (279a-b)

This divine impulse that leads to philosophy is nothing other than erōs, which is a leading of the soul to knowledge of the nature of things (cf. hormēn at 238b8, 251d2). This philosophy in him would draw him beyond competition for honors with rhetoricians like Lysias, whom content themselves with the courtroom rather than legislation and political reform, as does Isocrates, who early in his career expressed his great ambitions. ${ }^{90}$ Surely Isocrates would not consider such longing to be a form of madness. Nonetheless, Socrates' prophecy is muted, as he does not assert with certainty that Isocrates will develop this philosophy, only that he "might." Nor is Socrates clear that this impulse will

\footnotetext{
${ }^{90}$ Isoc. Panegyricus (Isoc. 4) 3-4. Isocrates reaffirms this at the end of his life (Isoc. 12.11). In a similar vein, consider how Glaucon's desire for something greater advances his and Socrates' philosophical inquiry into justice ( $R .372 \mathrm{c}$ ff.).
} 
lead Isocrates to philosophy, only "to something greater." If Plato insinuates that Isocrates never did develop this potential, it would not invalidate Socrates' prophecy, nor imply that Isocrates' work was not worthy of admiration. It is true that Isocrates never transcends political rhetoric in his written work; he only ridicules the speculations concerning nature that Socrates said was necessary for the perfection of rhetoric, ${ }^{91}$ and does not define the soul, as Socrates also demanded (270a, 270c-271c). He is aristocratic in his appeal to excellence of character for the sake of political unity, he is conservative in his praise of an older age in which the greatest offices were allotted according to virtue, ${ }^{92}$ and it is his concern for the welfare of the city that inspires his pan-Hellenism. ${ }^{93}$

His own care for the earthly grandeur of Athens and political devotion of its citizens is no doubt noble but perhaps obscures erōs as it is portrayed in the Phaedrus, as a great passion that must first lead the soul beyond the city in order to achieve a clear vision of what is in truth necessary for the individual soul.

Socrates only mentions, however, Isocrates' early work. Plato could be serious that there is a philosophical quality in Isocrates' work, perhaps more than is obvious. This does not imply that the two did not have real disagreements concerning the nature of political philosophy, ${ }^{94}$ but there were interesting similarities in their political writings, not least concerning rhetoric. For example, a number of Isocrates' works possess the criteria

\footnotetext{
${ }^{91}$ Isoc. 12.26-8, Antidosis (Isoc. 15) 261-6.

${ }^{92}$ Isoc. Areopagiticus (Isoc. 7) 23, 37.

${ }^{93}$ Isoc. 4, esp. $\$ 1-20,120-32$.

${ }^{94}$ One passage in particular is advanced as evidence of Isocrates' contempt for Plato's school, although it is oblique: "There are some who think themselves great, once having made a strange and absurd hypothesis, are able to speak on these things tolerably... [some] maintaining that courage and wisdom and justice are the same, that we have none of them by nature, but that there is one [kind of] knowledge concerning them all" (Isoc. 10.1). Isocrates never, however, mentions Plato by name, even when ridiculing the speculations of the sophists in the Antidosis (Isoc. 15.266-9). His argument that philosophy is for the sake of benefiting human beings in speech and action, using but not dwelling in speculative exercises, is not discordant with the Phaedrus's emphasis on the return to the earthly things and the city (pace McAdon 30-5).
} 
for artful rhetoric, particularly the use of definition. ${ }^{95}$ Also, Isocrates' Encomium of Helen emphasizes the development of the rhetorician's character and judgment concerning "the opportune moment" (to kairos), although he denies there is knowledge of the soul or that virtue can be taught, and denigrates precise knowledge (epistēmē) in favor of opinion $($ doxa $) .{ }^{96}$ It is also possible that Isocrates really was a noble writer as described by Socrates, capable of refuting what he wrote and possessed "things of greater value." There are some indications of this in Against the Sophists, where Isocrates points out the need to look beyond contradictions in speech, which the eristic sophists dwell on, to deeds as well. ${ }^{97} \mathrm{He}$ too seems to willfully contradict himself by claiming to teach while deriding knowledge. ${ }^{98}$ All these considerations are sufficient evidence that Plato, whatever his final assessment of Isocrates may have been, did in fact see "some philosophy" in Isocrates. As such, Isocrates' presence at the end of the Phaedrus does indeed serve a purpose useful to the work as a whole, for he is the possibility of a noble rhetoric that is not yet philosophical, even though it is to some extent inspired and reminded by it. He is akin to the lesser lovers of the palinode, who have not yet become philosophers because of their "love of honor," but "have an impulse [hormēn] to grow wings" in the future (256c-d). As seen in Socrates' first speech, it is the desire for glory

\footnotetext{
${ }^{95}$ Brown and Coulter 408. Brown and Coulter's argument, that Plato did not consider Isocrates to be philosophical because he indulged in "amphiboly" and did not use "true definitions," is, however, untenable (Ibid., 407-14). The whole discussion of rhetoric in the Phaedrus, oral and written, shows that a definition is only true so far as it leads the audience to what is true, rather than being a plain statement of the facts. They overlook Plato's own use of amphiboly for philosophic ends, and so misconstrue Plato's rhetoric as depending on the explicit presentation of "true theory," free of deception, which is curiously unrhetorical and indeed un-Platonic.

${ }^{96}$ Isoc. $10.2,7-8,12-17,21 ; 13.7-8,17 ; 15.271$.

${ }^{97}$ Isoc. 10.7-8. Also consider the Panathenaicus, published after Plato's death, in which Isocrates discusses using a written speech not as a frank disclosure of his opinion, but as a test for his friends who were accustomed to agreeing with him, in order to see whether they noticed its true intent and use of double meanings. That is, he produced a writing to provoke refutation and hide the truth in order to speak to a variety of audiences (Isoc. 12.234-265).

${ }^{98}$ Isoc. 10.7-8, 21. But cf. Isoc. 15.271: "it is in the nature of human beings to take hold of knowledge (epistēmē), which by holding we would see whatever must be done or said."
} 
and trust in the opinions of the many that prevents the flourishing of erōs and attainment of true knowledge. 99 Only if the noble writer is able to cultivate a higher desire that can rule his thumos will his rhetoric truly benefit the city. ${ }^{100}$ This "impulse" will always place him in tension with the city and traditionalism as such.

Phaedrus is ready to return to the city, now that the nature of shameful and noble writing has been revealed, and a succinct message has been formulated for his beloved Lysias. "The heat has become milder," he tells Socrates (279b). The sun's descent from its zenith accompanies and inspires the return to the city; its great heat resides in the personal contemplation of the soul outside the logos of the city and its opinions (cf. 242a). Although the city may conceal the experiences and nature of the soul, this concealment has also been shown to be necessary lest the soul become dazzled and put to sleep by the sun. It is through this logos, animated as it is by common opinions and desires and the background of assumptions about the nature of things, that the individual soul must ascend to grasp the beings themselves. Phaedrus cannot have the pure, unadorned, and endless pleasures that he believes are found in speeches; rather, he must regard the logos as a dim mirror in which he might spy something of the truth that lies behind their superficial appearance. Phaedrus and Socrates have therefore briefly ascended from the logos by purifying themselves, for the moment, of their opinions, but must descend again into the city and its opinions so that they may embody and put into practice what they saw, and thereby form an $\bar{e} t h o s$ that manifests their virtue.

\footnotetext{
${ }^{99}$ Brown and Coulter rightly compares Isocrates to the ethos of Socrates' first speech on the basis of Isocrates' defense of doxa over epistëmë (Brown and Coulter 409-10).

${ }^{100}$ Isocrates explicitly seeks the immortality of heroes and legislators: "not the immortality enjoyed by the gods, but that which implants in future generations a memorial of those who distinguished themselves through some noble deeds" (Isoc. 12.260).
} 
Since the gods of this sacred grove have filled them with the divine enthusiasm of philosophic love, it is fitting, Socrates says, that he and Phaedrus should pray to them before embarking on their "journey":

O Pan and the other gods in this place, give to me that I may become beautiful with respect to those things within, and that I have so much of those external things as to be friendly with those things inside me. And might I think [nomizein] the wise man is rich, and that I should have a pile of gold as great as a moderate man is able to carry or bear. (279b-c)

Pan, the rustic god of the logos who is half-man, half-goat, has been their patron today. His famously ugly countenance is charmingly mixed with wit and playfulness, in a fitting expression of the relation between the beauties available to the senses and the true beauty that is disclosed through logos to the mind alone. A similarly ugly Socrates wishes for only so much of that phantom beauty that will not weigh him down in what he only believes to be true and will direct him to what is truly worthy of seriousness. ${ }^{101}$ What is external is not therefore scorned, for it is necessary for mortal life in the body, and is formed in friendship with what is within - only a weaker bond than erōs, which wishes to possess and be in the presence of its beloved forever, will appropriately arrange what is inside and outside, being and becoming, truth and appearance, and knowledge and opinion.

The Phaedrus comes to an end, then, by returning to where it began, with moderation, now understood in its real and phantom forms. The "pile of gold" that Socrates would carry is a far cry from the "great amount of gold" Phaedrus would give for Lysias' skill (228a). Moderation reemerges after its apparent subordination to the madness of philosophic erōs, as it was only by hubristically penetrating what seemed to be fitting and measured that what is truly so could be discovered. This true moderation

${ }^{101}$ PI. Tht. 143a-144b, Smp. 221d-e, Ep. 2.314c; Xen. Smp. 4.19, 5.4-8. 
remains a prayer for Socrates, though, for until the hubristic searching of erōs can grasp what truly is, the nature of the truly moderate man will remain hidden. A man who believes he has attained something great by simply moderating his external things in relation to each other, rather than in relation to what is good for "the things inside him," that is, what is good for the soul, will only possess a phantom virtue.

Phaedrus joins in Socrates' prayer, "for the things of friends are held in common" (279c). While the two men first came together out of passion for Lysias' speech and Phaedrus's desire to show off the speech as his own, Socrates has led them into a truer community. He was able to distinguish from this initial passion a common desire, to grasp what is always unchanging, and upon revealing this desire persuade Phaedrus and Lysias that only philosophy could satiate it. This real community of friendship is thus established, through individual desire, as mutual participation in what really is, which alone can bring a human being into harmony with himself.

Socrates' final words recall the opening of the Phaedrus: "Dear Phaedrus, whither do you go and whence do you come?" Phaedrus was lost without realizing it, but through his serendipitous encounter with Socrates he has been reoriented, turned from his aimless erōs and stultifying moderation, which had produced in him the belief that the highest purpose of the logos was to generate painless pleasures. Only when that suppressed and hidden erōs was brought to light in conversation and examined in relation to what is truly needful was Phaedrus prepared to rejoin mortal life and seek a truly fitting logos. Socrates' palinode and criticism of writing has pointed Phaedrus towards what is truly beautiful. Now that the path has been discerned, his journey may continue: "Let us go." 


\section{CONCLUSION}

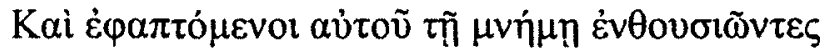

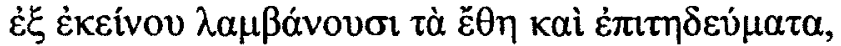

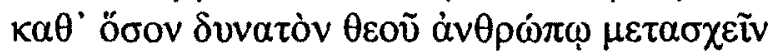
And grasping him through memory, being inspired by him, they take from him his ways and practices, and share in god to the greatest extent possible for a human being

Behind the resplendent lightness of Socrates' great palinode, Plato's Phaedrus has proven to be a rich, complex, and puzzling dialogue. The easy and smooth unfolding of the conversation between Socrates and Phaedrus, lightly touching upon such a variety of topics, is betrayed by and reveals a tension with a singularly focused meditation on the relation between the individual soul and the manner by which things become manifest to it. Over the course of the Phaedrus, Plato has brought to light, both by deed and by speech, the problem formed by the soul's ever-present desire to apprehend what is most fitting for it through its own opinions, the surface of things, which are a source of confusion and at best a reminder of what is truly desirable. No theory or doctrine of this phenomenon is possible, for Plato is concerned with how it is that the phenomena exist as phenomena ("what is shown") and how speech itself may persuade with respect to the nature of those phenomena. That is to say, because Plato wishes to bring to light the very conditions for speaking and writing, he must have recourse to a way of writing that sees through itself and becomes transparent to its object to the greatest extent possible. For Plato, the highest form of writing embodies the problem just outlined - it shows how speech concerning the ends of human life originates from and also perfects desire and action. 
In the opening pages, Plato illustrated the great power by which the art of speech had gripped the youth of Athens. Phaedrus in particular presents an ethic peculiarly well suited for exploring how speech acts upon the soul through the action of desire and pleasure, and yet for that very reason allows a shallow kind of persuasion that denies the full power of speech. In the urbane speeches of Lysias and Socrates, the proximate source of this ethic is introduced as the impossible position of non-love, which appears plausible because of the wide range of incommensurable opinions to which lovers may be led. Men like Lysias and Phaedrus would have recourse to a kind of passionless discourse based on what is evident to all. Socrates' cogent and logical development of this position, and therewith its purely rational discourse, reveals it to be an impossible conjunction of opposites. But the urbane speeches do provide an account of erōs that is a useful springboard for Socrates to illustrate the full nature of erōs that is presupposed by speech, even the speech of non-love. Socrates feigns to transcend speech itself in order to illustrate how it is that speech is the manner by which reality is perceived by soul, which perceives itself as being in tension and perpetual motion towards complete rest and unity. Beauty emerges as the principal object of this myth because it is the principal object of erōs. Insofar as reason is moved by the desire for what is whole, complete, and fitting for the soul, it too is under the sway of beauty. When this desire is gratified by the perception of beauty, such pleasure is produced that it must be met with the awareness that this is the source of deception, for it leads one away from the truly simple and pure beauty that is perceptible by thought alone. The highest of lovers become moderate in their desires for one another as they pursue this most perfect beloved. 
In hindsight, rather than simply being an exoneration of erōs, Socrates' palinode serves to show the very objects and structure of speech by which it is capable of persuasion. Over the course of Socrates' extensive discussion with Phaedrus on the nature of rhetoric, it emerges that rhetoric and persuasion are in fact only possible insofar as they touch on what really is and provide some simulacrum of knowledge and truth. Rhetoric must have at its heart some perception of reality if it is to become artful, and this heart is nothing other than dialectic. Rhetoric is in essence dialectical, and so dialectic resembles rhetoric; in their perfection, the two cannot be differentiated. Still, it is difficult for Socrates to show that dialectic necessarily reveals what really is, since it depends on seeing clearly the nature of soul that all speech presupposes. Without the perfect knowledge of the true art of rhetoric, rhetoric that eschews the close reasoning of dialectic retains great efficacy with variegated and inexpert audiences - the great majority of humanity. Plato seizes on this tension between Socrates' private rhetoric and the public rhetoric of the rhetoricians as a way to inquire about his own medium of writing. From the inadequacies of writing in the latter mode, Plato points towards a kind of writing that combines the static and public nature of the written word with the fluid adaptation of oral discourse. Rather than writing as if a text were a fixed monument capable of endlessly dispensing the truth to all, a noble kind of writing must playfully indicate its own insufficiencies in light of a truth that is perceptible only through the efforts of the individual reader. Plato writes so as to instill a sense of longing and desire for a coherent, unified, and timeless truth upon which may develop an ethic that, if not philosophical, is at least persuaded of and open to the needfulness of the truth and a life spent in pursuit of it. 
The Phaedrus appears as not only an exoneration of rhetoric and the art of speech, but in fact as the well-spring of Plato's written and therefore public project to situate philosophy - what will later be understood as science - at the heart of ethical and political life. Socrates shows Phaedrus how the manner by which one speaks both reflects our ethic, our way of life and comportment to others, and shapes how we conceive of and interact with reality. Instead of regarding speech simply as the instrument and means to the indeterminate ends of a speaker, an unproblematic reflection of self-evident facts, speech emerges as the instrument for investigating the nature of those ends and determining their relative value for human life. It is only through this private use of speech to clarify our own understanding of the nature of things that rhetoric is, on the one hand, disarmed and disenchanted, and, on the other, harnessed to the cultivation of the greatest of goods. Through Socrates' intimate and apparently extrapolitical discussion with Phaedrus, Plato shows how the seeds of philosophy and ultimately science are sown within the individual soul as the way to discover and accomplish what is most fitting and desirable for our own lives. As a politic exercise of rhetoric in its own right, the Phaedrus sows the seeds for this private rhetoric - to be either ardently pursued or at the least made amenable to it - through beautiful images of the goods of the soul that are by self-admission merely images and propaedeutic to philosophy as a way of life. Just as noble rhetoric grows from dialectic, so too does Plato's rhetoric grow as the resplendent exterior and simulacrum of the still greater beauty that lies in the soul's exercise of its highest powers. The place of the Phaedrus in Plato's larger political project can therefore be understood as a kind of prologue or 
initiation by which speech, and therewith the possibility of philosophy, is rehabilitated as a way towards the recovery of what really is.

For the reader of the Phaedrus situated within the modern malaise of rhetorical study, its rehabilitation of the art of rhetoric stands out as a particularly strange defense of what has been, even what must be, indefensible. Plato advocates a rhetorical supplement to dialectic and reasoning - a recommendation that may be grudgingly acknowledged in the face of various fronts of resistance to scientific expertise and consensus. But this is the weakest aspect of Plato's rehabilitation of rhetoric. Stronger is his delineation, through Socrates, of a prospectus for a perfectly efficacious rhetoric; in modern terms, Plato proposes a science of rhetoric. Yet stronger still is that this perfect rhetoric is rooted in a dialectical analysis of soul and speech. Even granting that this perfect rhetoric may be impossible, this close identification of dialectic and rhetoric contradicts the clear modern distinction. If science and reasoning is rhetorical, one might wonder, have we already said "goodbye to the truth"? Is science stripped of its secure foundations in reality? That may be, if speech is understood the way Phaedrus, Lysias, and Thrasymachus understood it, as an instrument that is unrevealing of what is best for the human being who uses it. For Plato, the power of rhetoric to captivate an audience by arousing its passions is not exclusive to rhetoric - it is a power shared by all speech, including dialectic and reasoning. The most controversial element of the Phaedrus was fittingly ornamented in the most resplendent rhetoric of the dialogue: the nourishment of the soul in the clear light of "the plain of truth." What is desirable and good is implicit in the use of speech. Not only is speech naturally related to and revealing of reality, but we share in that reality for the sake of our good. Only the power of speech to discern what 
truly is better or worse can justify the differentiation of Socratic dialectic and science from rhetoric. Moreover, rhetoric, at least in the defense of philosophy and science, if not in all education, is demanded by the natural differentiation of souls according to their noetic vision or, more plainly, their intellectual capacity. Rhetoric is a necessary consequence of the understanding that nature implies a hierarchy of beings and goods, and that thinking is correspondingly an ascent through their forms. Rather than guard science from the admittedly dangerous power of rhetoric, as Hobbes did, Plato runs the risk of incorporating it, for it is only in this way that philosophy and reason may really recommend themselves to the human soul. From this view, the enormity of the task of rehabilitating rhetoric is seen most plainly. The Platonic teaching upon which the classical tradition of rhetoric was founded is nothing less than the goodness of the way of the logos. 


\section{BIBLIOGRAPHY}

Al-Fārābī. 1962. Alfarabi's Philosophy of Plato and Aristotle. Trans. Madhi, Muhsin. Ithaca, NY: Cornell University Press.

Beercroft, Alexander J. Spring 2006. "'This is not a true story': Stesichorus's Palinode and the Revenge of the Epichoric." Transactions of the American Philological Association 136.1 The John Hopkins University Press, 47-70.

Belfiore, Elizabeth. 2006. "Dancing with the Gods: The Myth of the Chariot in Plato's Phaedrus". American Journal of Philology 127: 185-217.

Benardete, Seth. 1991. The Rhetoric of Morality and Philosophy. Chicago: University of Chicago Press.

Bentley, Russell. 2005. "On Plato's Phaedrus: Politics Beyond the City Walls". Polis 22.2: $230-48$.

Bett, Richard. 2000. "Immortality and the Nature of the Soul in the Phaedrus" in Plato, ed. Fine, Gail. Oxford: Oxford University Press. 907-31.

Brisson, Luc. 1998 [1994]. Plato the myth maker. Trans. Naddaf, Gerrard. Chicago: University of Chicago Press.

Brown, Malcolm, and Coulter, James. October 1971. "The Middle Speech of Plato's Phaedrus." Journal of the History of Philosophy 9.4: 405-23.

Brumbaugh, Robert S. 1961. Plato on the One: the Hypotheses in the Parmenides. New Haven: Yale University Press.

Buccioni, Eva M. 2002. "The Psychical Forces in Plato's Phaedrus". British Journal for the History of Philosophy 10.3: 331-57.

Budge, E. A. Wallis. 1955. The Book of the Dead. New York: Bell Publishing Compnay.

Burger, Ronna. 1980. Plato's Phaedrus : A Defense of a Philosophic Art of Writing. Tuscaloosa: University of Alabama Press.

Burnet, John. 1901. Platonis Opera. $2^{\text {nd }}$ edition. Oxford: Oxford University Press.

Campbell, David A., ed. and trans. 1991. Greek Lyric, Volume III: Stesichorus, Ibycus, Simonides, and Others. Cambridge, MA: Harvard University Press.

- 1988. Greek Lyric, Volume II: Anacreon, Anacreontea, Choral Lyric from Olympus to Alcman. Cambridge, MA: Harvard University Press. 
- 1982. Greek Lyric, Volume I: Sappho and Alcaeus. Cambridge, MA: Harvard University Press.

Clay, Diskin. 2007. "Plato Philomythos." The Cambridge Companion to Greek Mythology. Ed. Woodard, Roger D. Cambridge: Cambridge University Press, 210-36.

Collard, Christopher, and Cropp, Martin. 2009. Euripides VIII, Fragments. Cambridge, MA: Harvard University Press.

Cook, Albert. 1985. "Dialectic, Irony, and Myth in Plato's Phaedrus." The American Journal of Philology 106.4: 427-41.

De Vries, G. J. 1969. A Commentary on the Phaedrus of Plato. Amsterdam: Adolf M. Hakkert.

Derrida, Jacques. 1981 [1972]. "Plato's Pharmacy". Dissemination. Trans. Johnson, Barbara. Chicago: University of Chicago Press, 61-172.

Diels, Hermann. 1952 [1903]. Die Fragmente der Vorsokratiker. $6^{\text {th }}$ ed. Rev. Kranz, Walther. Berlin: Weidmann.

Dillon, J. 1973. Iamblichi Chalcidensis in Platonis dialogos commentariorum fragmenta. Leiden: E. J. Brill.

Dorter, Kenneth. July 1971. "Imagery and Philosophy in Plato's Phaedrus". Journal of the History of Philosophy 9.3: 279-88.

Dover, Kenneth James. 1978. Greek Homosexuality. Cambridge, MA: Harvard University Press.

-1968. Lysias and the corpus Lysiacum. Berkeley: University of California Press.

Ferrari, Giovanni. 1988. "Self-Knowledge in Plato's Phaedrus by Charles L. Griswold, Jr." The Philosophical Review 97.3: 408-11.

- 1987. Listening to the Cicadas: a study of Plato's Phaedrus. Cambridge: Cambridge University Press.

Ficino, Marsilio. 1985. Commentary on Plato's Symposium on Love. Ed. and trans. Jayne, Sears. Dallas: Spring Publications, Inc.

1981. Marsilio Ficino and the Phaedran Charioteer. Ed. and trans. Allen, Michael J. B. Berkeley and Los Angeles: University of California Press. 
Foucault, Michel. 1983. "The Subject and Power," in Michel Foucault: Beyond Structuralism and Hermeneutics. Eds. Hubert L. Dreyfus and Paul Rabinow. Second edition. Chicago: University of Chicago Press.

- 1980. Power/Knowledge: Selected Interviews and Other Writings 1972-1977. Ed. Colin Gordon. Sussex: The Harvester Press Limited.

Friedländer, Paul. 1958 [1954]. Plato. 3 vols. Trans. Meyerhoff, Hans. New York: Pantheon Books Inc.

Furley, William D. 1996. Andokides and the Herms, A Study of Crisis in fifth-century Athenian Religion. Bulletin of the Institute of Classical Studies Supplement 65. London: Institute of Classical studies, University of London.

Gadamer, Hans-Georg. 1991. Plato's Dialectical Ethics: Phenomenological Interpretations Regarding the Philebus. Trans. Wallace, Robert M. New Haven: Yale University Press.

- 1989 [1975]. Truth and Method. $2^{\text {nd }}$ ed. Trans. Marshall, Donald G., and Weinsheimer, Joel. London: Continuum Publishing Group.

Gaonkar, Dilip P. 1997. "The Idea of Rhetoric in the Rhetoric of Science," in Rhetorical Hermeneutics: Invention and Interpretation in the Age of Science. Eds. Alan G. Gross and William M. Keith. Albany: State University of New York Press; 2585.

Gould, Thomas. 1963. Platonic Love. New York: Free Press of Glencoe.

Griswold, Charles L. 1986. Self-knowledge in Plato's Phaedrus. Pittsburgh: Pennsylvania State University Press.

Gross, Alan G. 1990. The Rhetoric of Science. Cambridge, MA: Harvard University Press.

Hackforth, Reginald. 1952. Plato's Phaedrus: Translated with Introduction and Commentary. Trans. Hackforth, Reginald. Cambridge: Cambridge University Press.

Heidegger, Martin. 1997 [1992]. Plato's Sophist. Trans. Rojcewicz, Richard, and Schuwer, André. Bloomington and Indianapolis: Indiana University Press.

Hermeias. 1971. Hermiae Alexandrini in Platonis Phaedrum Scholia. Ed. Couvreur, P. New York: G. Olms.

Hobbes, Thomas. 1994. Leviathan. Curley, Edwin. Indianapolis: Hackett Publishing Company, Inc. 
- 1839-1845. The English Works of Thomas Hobbes of Malmesbury. Vols. 1-11. Ed. Molesworth, Sir William. London: John Barns.

Howland, Jacob. Autumn, 1991. "The Problem of Platonic Chronology". Phoenix 45.3: 189-214.

Hyland, Drew A. 2008. Plato and the Question of Beauty. Bloomington: Indiana University Press.

Inscriptiones Graecae. 1981. $3^{\text {rd }}$ ed. Ed. David M. Lewis. Berlin: de Gruyter.

Jaeger, Werner. 1944. Paideia: The Ideals of Greek Culture. 3 vols. Trans. Highet, Gilbert. Oxford: Oxford University Press.

Jowett, Benjamin. 1892. Phaedrus. Trans. Jowett, Benjamin. Oxford: Oxford University Press.

Kennedy, George A. 1980. Classical Rhetoric and Its Christian and Secular Tradition from Ancient to Modern Times. Chapel Hill: The University of North Carolina Press.

- 1963. The Art of Persuasion in Greece. Princeton, NJ: Princeton University Press.

Kerényi, Karl. 1967 [1960]. Eleusis: Archetypal Image of Mother and Daughter. Trans. Manheim, Ralph. New York, NY: Bollingen Foundation.

Klein, Jacob. 1965. A Commentary on Plato's Meno. Chicago: The University of Chicago Press.

Koritansky, John C. 1987. "Socratic Rhetoric and Socratic Wisdom in Plato's Phaedrus." Interpretation: A Journal of Political Philosophy 15.1: 29-53.

Lebeck, Anne. 1972. "The Central Myth of Plato's Phaedrus." Greek, Roman and Byzantine Studies 13.3: 267 - 90.

Liddell, H. G., and Scott, R. 1996. A Greek-English Lexicon. Supplem. Jones, H. S. Oxford: Oxford University Press.

Lincoln, Bruce. 1997. "Competing Discourses: Rethinking the Prehistory of Mythos and Logos." Arethusa 30: 341-67.

Linforth, Ivan M. 1946a. "Telestic Madness in Plato, Phaedrus 244de". University of California Publications in Classical Philology 13.6: 163-72.

. 1946b. The Corybantic Rites in Plato. Berkley: University of California Press.

Lloyd-Jones, Hugh. 1996. Sophocles: Fragments. Cambridge, MA: Harvard University Press. 
MacDowell, Douglas M. 1978. The Law in Classical Athens. London: Thames and Hudson Ltd.

- ed. and trans. 1962. Andocides IV: On the Mysteries. Oxford: Clarendon Press.

Mansfeld, Jaap. 1980. "Plato and the Method of Hippocrates." Greek, Roman, and Byzantine Studies 21 (4): 341-62.

McAdon, Brad. 2004. "Plato's Denunciation of Rhetoric in the Phaedrus." Rhetoric Review 23.1: 21-39.

Morgan, Kathryn A. 2000. Myth and Philosophy from the Presocratics to Plato. Cambridge University Press.

- 1994. "Socrates and Gorgias at Delphi and Olympia: PHAEDRUS 235d6236b4." The Classical Quarterly 44.2: 375-86.

Mylonas, George E. 1961. Eleusis and the Eleusinian mysteries. New Jersey: Princeton University Press.

Nails, Debra. 2002. The People of Plato: A Prosopography of Plato and Other Socratics. Indianapolis: Hackett Publishing Company.

Nehamas, Alexander. 1999. "The Phaedrus." Virtues on Authenticity: Essays on Plato and Socrates. Princeton, NJ: Princeton University Press; 329-58.

Nehamas, Alexander, and Woodruff, Paul. 1995. Phaedrus: Translated, with Introduction and Notes. Indianapolis: Hackett Publishing Company.

Newell, Waller R. 2000. Ruling Passion: The Erotics of Statecraft in Platonic Political Philosophy. Lanham, Md: Rowman \& Littlefield.

Nichols Jr., James H., trans. 1998. Plato, Phaedrus; translated with introduction, notes, and an interpretive essay. Ithaca: Cornell University Press.

Nicholson, Graeme. 1999. Plato's Phaedrus: The Philosophy of Love. West Lafayette, Indiana: Purdue University Press.

Nussbaum, Martha C. 1986. The Fragility of Goodness: Luck and Ethics in Greek Tragedy and Philosophy. Cambridge: Cambridge University Press.

Parke, H. W. 1988. Sibyls and Sibylline Prophecy in Classical Antiquity. Ed. McGing, B.C. London: Routledge.

- 1967. The Oracles of Zeus: Dodona, Olympia, Ammon. Oxford: Blackwell. 1956. The Delphic Oracle. 2 vols. Oxford: Blackwell. 
Pickard-Cambridge, A. W. 1927. Dithyramb, Tragedy and Comedy. Oxford: Oxford University Press.

Pieper, Josef. 1964. Enthusiasm and divine madness; on the Platonic dialogue Phaedrus. Trans. Winston, Richard, and Winston, Clara. New York: Harcourt.

Planinc, Zdravko. 2001. "Homeric Imagery in Plato's Phaedrus". Politics, Philosophy, Writing. Ed. Planinc, Zdravko. Columbia: University of Missouri Press; 122-59.

Ramus, Petrus. 2010. Arguments in Rhetoric Against Quintilian: Translation and Text of Peter Ramus's Rhetoricae Distinctiones in Quntilianum. Ed. Murphy, James. Trans. Newlands, Carole. Southern Illinois University Press.

- 1992. Peter Ramus's Attack on Cicero: Text and Translation of Ramus's Brutinae Quaestiones. Ed. Murphy, James. Trans. Newlands, Carole. Davis, CA: Hermagoras Press.

Rhodes, James M. 2003. Eros, Wisdom, and Silence: Plato's Erotic Dialogues. Columbia: University of Missouri Press.

Rosen, Stanley. 1990. "The Golden Apple." Arion 1.1. Trustees of Boston University. 187-207.

—. 1969. "The Non-lover in Plato's Phaedrus". Man and world 2.3: 423-37.

Rossetti, Livio, ed. 1992. Understanding the Phaedrus: proceedings of the II Symposium Platonicum. Sankt Augustin: Academia Verlag.

Rowe, C. J. 1986. Plato: Phaedrus, with Translation and Commentary. Trans. Rowe, C. J. Wiltshire: Aris and Phillips Ltd.

Rutherford, R. B. 1995. The Art of Plato: Ten Essays in Platonic Interpretation. Cambridge, MA: Harvard University Press.

. 1988. "Plato and Lit. Crit." Phronesis 33.2: 216-24.

Sallis, John. 1996. Being and Logos: Reading the Platonic Dialogues. $3^{\text {rd }}$ ed. Bloomington: Indiana University Press.

Santas, Gerasimos. 1982. "Passionate Love in the Phaedrus". Ancient Philosophy 2.2: $105-14$.

Schleiermacher, Friedrich Daniel Ernst. 1936 [1804]. Schleiermacher's Introductions to the Dialogues. Ed. and trans. Dobson, William. Cambridge: Cambridge University Press.

Seeskin, Kenneth. 1987. Dialogue and Discovery: A Study in Socratic Method. New York: SUNY Press. 
Shorey, Paul. 1933. "On the Erotikos of Lysias in Plato's Phaedrus." Classical Philology 28 (2): 131-2.

Simons, Herbert W. 1990. The Rhetorical Turn: Invention and Persuasion in the Conduct of Inquiry. Chicago: The University of Chicago Press.

Sinaiko, Herman L. 1965. Love, Knowledge, and Discourse in Plato. Chicago: University of Chicago Press.

Skemp, J. B. 1967 [1942]. The Theory of Motion in Plato's Later Dialogues. Amsterdam: Adolf M. Hakkert.

Slaveva-Griffin, Svetla. 2003. "Of Gods, Philosophers, and Charioteers: Content and Form in Parmenides' Proem and Plato's Phaedrus." Transactions of the American Philological Association 133: 227-53.

Smyth, Herbert Weir. 1984 [1920]. Greek Grammar. Cambridge, MA: Harvard University Press.

Sommerstein, Alan H. 2009. Aeschylus II, Fragments. Cambridge, MA: Harvard University Press.

Strauss, Leo. 2001. On Plato's Symposium. Chicago: University of Chicago Press.

Thompson, W. H. 1973 [1868]. The Phaedrus of Plato, with English Notes and Dissertations. Trans. Thompson, W. H. New York: Arno Press Inc.

Vlastos, Gregory. 1991. Socrates, ironist and moral philosopher. Ithica, N.Y.: Cornell University Press.

- 1981 [1973]. "The Individual as an Object of Love in Plato." Platonic Studies. Princeton University Press; 3-34.

Voeglin, Eric. 1999-2001. Order and History. 5 vols. The Collected Works of Eric Voeglin. Vols. 14-18. Ed. Sandoz, Ellis. Columbia: University of Missouri Press.

Weaver, Richard. 1953. The Ethics of Rhetoric. South Bend, Indiana: Regnery/Gateway, Inc.

White, David A. 1993. Rhetoric and Reality in Plato's Phaedrus. New York: State University of New York Press.

Wilamowitz-Moellendorff, Ulrich von. 1917. Platon. 2 vols. Berlin.

Woodford, Susan. 1994. "Palamedes Seeks Revenge." The Journal of Hellenic Studies $114 ; 164-9$.

Yunis, Harvey, ed. 2011. Plato: Phaedrus. Cambridge: Cambridge University Press. 
- 2005. "Eros in Plato's Phaedrus and the Shape of Greek Rhetoric." Arion 13.1: $101-25$.

Zaslavsky, Robert. 1981. "A Hitherto Unremarked Pun in the Phaedrus." Apeiron 15.2: 115-6. 


\section{APPENDIX I:}

\section{Synopsis of the Phaedrus}

I. Introduction and dramatic setting

a. Phaedrus and Socrates go for a walk outside of Athens

$(227 \mathrm{a}-230 \mathrm{e})$

$(227 \mathrm{a}-228 \mathrm{~b})$

b. Socrates on myth and self-knowledge

(229b-230a)

c. Idyllic grove under a plane-tree (the metaxy)

(230b-e)

II. Phaedrus reads Lysias' speech

a. Thesis: beloved should give favors to a non-lover rather than a lover

$(230 \mathrm{e}-234 \mathrm{~d})$

(230e-231a)

b. Antitheses: non-lover is superior to the mad and fickle lover

(231a-233d)

c. Summary and conclusion

(233d-234d)

III. First interlude

a. Socrates ridicules Lysias' speech and boasts he could tell it more beautifully

IV. Socrates' first speech, imitating Lysias'

a. Proem: invocation of the Muses

$(234 \mathrm{e}-237 \mathrm{a})$

b. Prologue: non-lover is in fact a concealed lover

c. Speech of the concealed lover I: deliberation and definition of eros

d. Socrates' bacchic interruption

e. Speech of the concealed lover II: harmfulness of the lover
i. Soul
ii. Body
iii. Possessions
iv. Associations
v. Pleasures
vi. Oaths

f. Socrates' refusal to praise the non-lover

$(237 a-241 d)$

(237a-b)

$(237 \mathrm{~b}-238 \mathrm{c})$

$(238 \mathrm{c}-\mathrm{d})$

$(238 \mathrm{~d}-241 \mathrm{~d})$

V. Second interlude

a. Socrates' shame and daimonion

VI. Socrates' second speech (Palinode to Eros)

a. Beneficence of mania and love as highest form

b. Proof of the immortality of soul as first principle of motion

c. Image of the soul as winged chariot

d. Chariots of the gods and their ascent

e. Superheavenly place where being itself is seen

f. Chariots of mortals, their descent into the body, and hierarchy of soul types

g. Reincarnation of the soul and reasoning/recollection

h. Recollection and eros

i. Ecstatic inspiration of beauty

j. Search for god

k. Capturing the beloved

i. Mastering of the team

ii. Reflection of love

iii. Mutual pursuit of philosophy

VII. Discussion of rhetoric

$(257 c-274 b)$

$(257 \mathrm{c}-258 \mathrm{~d})$

(258e-259d)

Written speeches and law

(259d-261a)

c. Rhetoric and knowledge

i. Phaedrus's definition of rhetoric

ii. Deception from ignorance and the argument of use

iii. The boast of the art of rhetoric: all arts require her to persuade 
iv. Spartan's genuine art

d. Psychagogia: public and private rhetoric

e. Antilogic: persuasion from one thing to its opposite through semblances

(261a-c)

$(261 \mathrm{c}-262 \mathrm{c})$

f. Analysis of the three speeches

i. Mark disputable terms

ii. Definition

iii. Logographic necessity

g. Dialectic

i. Collection and division

ii. Socrates' love of dialectic

h. Rhetorical techniques

i. Rhetorical handbooks and techniques

ii. Art and proper use of technique (medicine; poetry; rhetoric)

i. Noble rhetoric

i. Recourse to nature

ii. Method of Hippocrates

iii. Dialectical analysis of souls and speeches

j. Probabilistic argument

$(266 \mathrm{c}-269 \mathrm{e})$

$(269 \mathrm{e}-272 \mathrm{c})$

$(272 c-274 b)$

VIII. Discussion of writing

$(274 b-278 b)$

a. Egyptian myth of Theuth and Thamos

$(274 \mathrm{c}-275 \mathrm{c})$

b. Defects of writing

c. Writing on the soul

$(275 \mathrm{c}-275 \mathrm{e})$

(276a)

d. Two farmers and two kinds of writing

(276b-e)

e. Noble writing

(276e-278b)

IX. Conclusion

$(278 \mathrm{~b}-279 \mathrm{c})$

a. Messages for Lysias and Isocrates

$(278 b-279 b)$

b. Prayer to Pan and return to Athens

$(279 b-c)$ 


\section{APPENDIX II:}

The Three Divisions of Eros

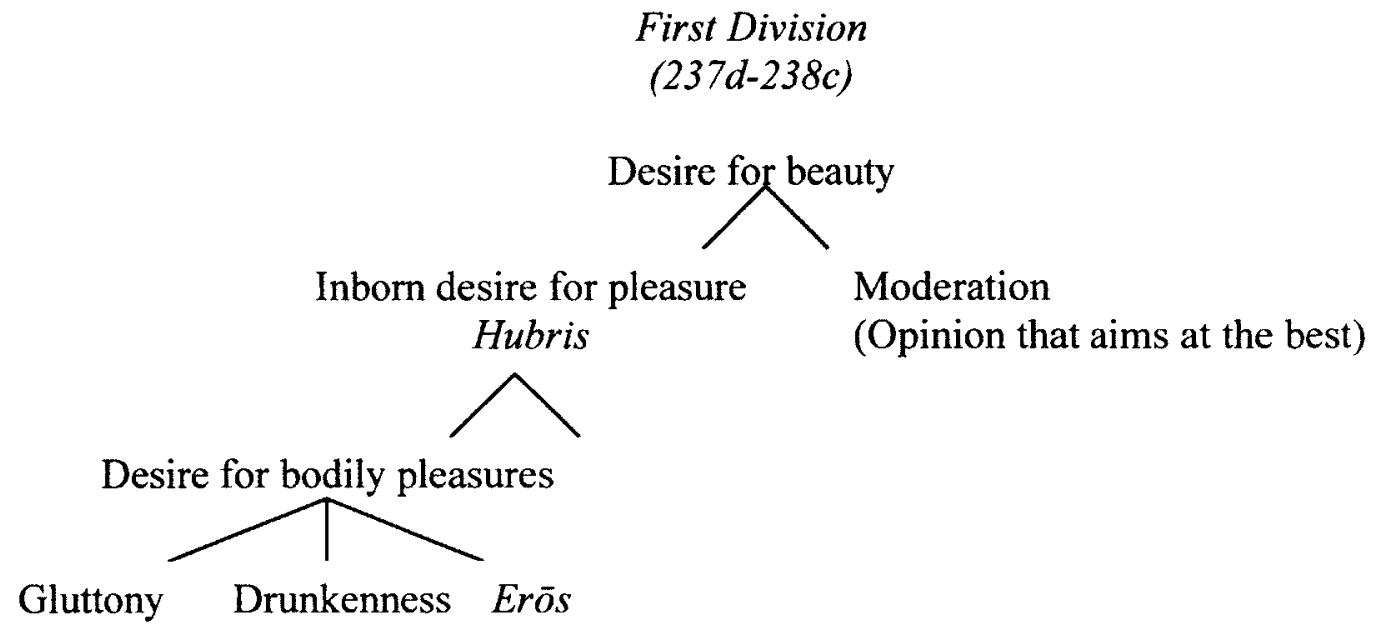

Second Division

(244a-245c, 265b-c)

Madness

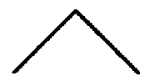

(Human illness)
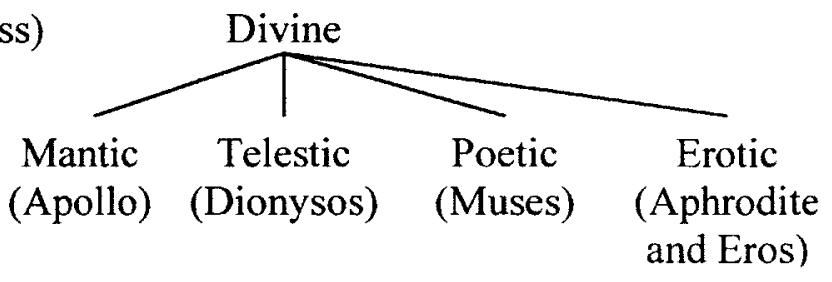

Third Division

(265e-266a)

Mind

Dianoia

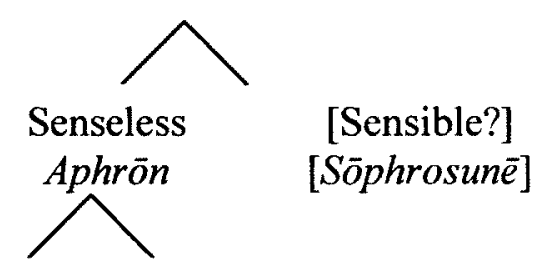

[Human?] Divine

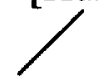

Left-handed

erōs
Right-handed

erōs 